Helene Ingierd | Ingrid Bay-Larsen | Kjellrun Hiis Hauge (red.)

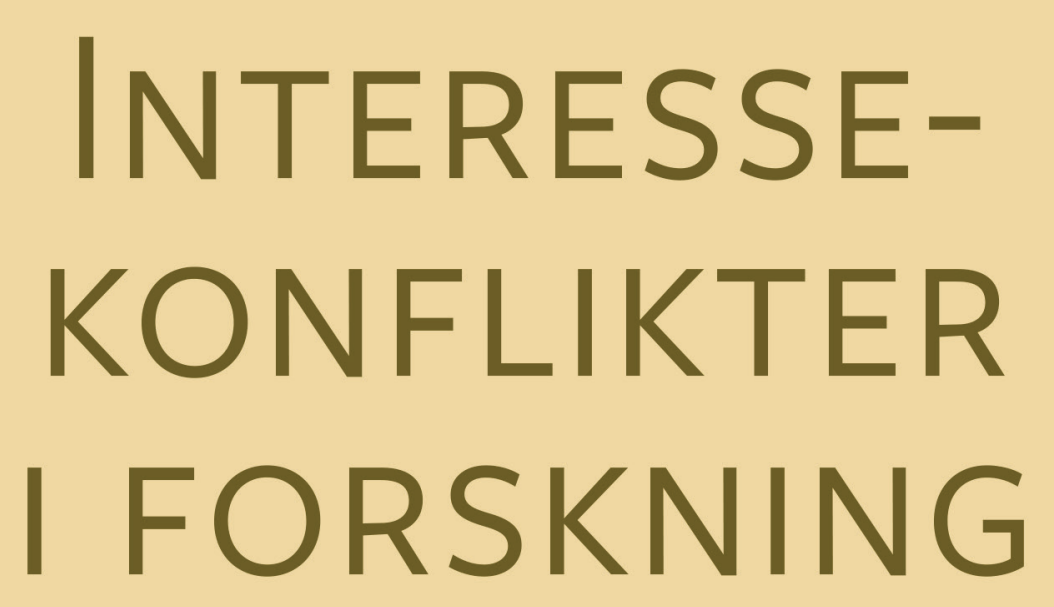


Interessekonflikter i forskning 

Helene Ingierd, Ingrid Bay-Larsen og Kjellrun Hiis Hauge (red.)

\section{Interessekonflikter i forskning}


(C) 2019 Helene Ingierd, Ingrid Bay-Larsen, Kjellrun Hiis Hauge, Gisle Andersen, Maiken Bjørkan, Tone G. Bjørndal, Anders Braarud Hanssen, Geir Gaarder, Stig S. Gezelius, Erlend A.T. Hermansen, Olve Krange, Klaus Mittenzwei, Bjørn K. Myskja, Rune Nydal, Audun Ruud, Bjørn H. Samset, Bjørn H. Samset, Berge Solberg, Norunn Sæther Myklebust, Kristin Wangen og Øystein Aas.

Dette verket omfattes av bestemmelsene i Lov om opphavsretten til åndsverk m.v. av 1961. Verket utgis Open Access under betingelsene i Creative Commons-lisensen CC-BY 4.0 (http://creativecommons.org/licenses/by/4.0/). Denne tillater tredjepart å kopiere, distribuere og spre verket i hvilket som helst medium eller format, og å remixe, endre, og bygge videre på materialet til et hvilket som helst formål, inkludert kommersielle, under betingelse av at korrekt kreditering og en lenke til lisensen er oppgitt, og at man indikerer om endringer er blitt gjort. Tredjepart kan gjøre dette på enhver rimelig måte, men uten at det kan forstås slik at lisensgiver bifaller tredjepart eller tredjeparts bruk av verket.

Boka er utgitt med støtte fra De nasjonale forskningsetiske komitéene.

ISBN trykt bok: 978-82-02-63748-4

ISBN PDF: 978-82-02-58817-5

ISBN EPUB: 978-82-02-63660-9

ISBN HTML: 978-82-02-63662-3

ISBN XML: 978-82-02-63661-6

DOI: https://doi.org/10.23865/noasp.63

Dette er en fagfellevurdert antologi, med unntak av kapitlene 4, 10 og 11.

Omslagsdesign: Cappelen Damm AS

Cappelen Damm Akademisk/NOASP

noasp@cappelendamm.no 


\section{Innhold}

Introduksjon .7

Helene Ingierd, Kjellrun Hiis Hauge og Ingrid Bay-Larsen

Kapittel 1 Interessekonflikter i forskning: Om forskningens

saksorienterte forpliktelse 19

Rune Nydal, Berge Solberg og Bjørn Myskja

Kapittel 2 Forskerens frihet når interesser vil styre .45

Stig S. Gezelius og Klaus Mittenzwei

Kapittel 3 Interesse- og verdikonflikter i skjæringspunktet mellom patentetikk og forskningsetikk .69

Anders Braarud Hanssen

Kapittel 4 Den skjulte styringen. 91

Ketil Skogen, Audun Ruud og Olve Krange

Kapittel 5 Kunnskapsbasert forvaltning og dilemmaer knyttet til usikkerhet 107

Maiken Bjørkan og Kjellrun Hiis Hauge

Kapittel 6 Den menneskeskapte iskanten - Om vitenskapelig sannhetssøken og uavhengighet $i$ en kunnskapsbasert forvaltning 131

Ingrid Bay-Larsen, Erlend A.T. Hermansen og Tone G. Bjørndal

Kapittel 7 Forskning for politikk: Om uavhengighet i direktoratsektoren ... 153 Gisle Andersen

Kapittel 8 øt legitimitet til konsekvensutredninger i Norge Kan okt bevissthet om organisering og endrede roller styrke tilliten til ordningen? 177

Oystein Aas

Kapittel 9 Kartlegging og verdisetting av naturtyper 191

Geir Gaarder og Kristin Wangen 
INNHOLD

Kapittel 10 «... så korrupte at jeg har ikke ord!» - Hets og sjikane i forskning 215

Norunn S. Myklebust

Kapittel 11 Styrke og veiledning: Forskningsformidling i møte med særinteresser 231

Bjørn H. Samset

Om bidragsyterne... 253 


\title{
Introduksjon
}

\author{
Helene Ingierd
}

Sekretariatsleder, Den nasjonale forskningsetiske komité for naturvitenskap og teknologi (NENT)

\section{Kjellrun Hiis Hauge}

Forskningsprogramleder, Høgskulen på Vestlandet og medlem i Den nasjonale forskningsetiske komité for naturvitenskap og teknologi (NENT)

\section{Ingrid Bay-Larsen}

Forskningsleder, Nordlandsforskning og medlem i Den nasjonale forskningsetiske komité for naturvitenskap og teknologi (NENT)

\section{Bakgrunn}

Denne antologien tematiserer ulike etiske aspekter ved interessekonflikter i forskning. Den nasjonale forskningsetiske komité for naturvitenskap og teknologi (NENT) har fått flere henvendelser de siste årene, der det problematiseres hvordan forskere, akademiske institusjoner og prosjekter styres av politiske eller økonomiske interesser, der forskningsresultater trekkes i tvil, og der det fremmes anklager om fusk eller dårlig kvalitet. ${ }^{1}$ Et fellestrekk ved disse sakene er at de har fulgt politiske skillelinjer rundt industri, havbruk, bruk eller vern av naturverdier m.m. De siste årene har det også vært offentlig debatt om politikernes bruk av forskning, der uttalelser fra flere statsråder har vekket bekymring. Tidligere fiskeriminister Per Sandberg fikk kritikk fra flere hold da han uttalte

1 Se uttalelser fra NENT på www.etikkom.no

Sitering av dette kapitlet: Ingierd, H., Hiis Hauge, K., \& Bay-Larsen, I. (2019). Introduksjon: Interessekonflikter i forskning. I H. Ingierd, I. Bay-Larsen \& K. Hiis Hauge (Red.), Interessekonflikter i forskning (s. 7-18). Oslo: Cappelen Damm Akademisk. https://doi.org/10.23865/noasp.63.cho Lisens: CC BY 4.0 
at Havforskningsinstituttet skal være et næringsvennlig institutt og dele ambisjonene regjeringen har for oppdrettsnæringen. ${ }^{2}$ Tidligere innvandringsminister Sylvi Listhaug ble beskyldt for å tolke forskningsrapporter på en måte som forfatterne ikke kjenner seg igjen i. ${ }^{3}$ Flere forskere har også ropt varsku om økende grad av oppdragsforskning og kommersialisering av forskningen generelt. ${ }^{4}$

I sum kan dette bidra til at tilliten til forskning settes på prøve. Den globale diskursen om det post-faktuelle samfunnet viser til en samfunnsdebatt som i stor grad styres av følelser og subjektive oppfatninger (alternative fakta), på bekostning av et offentlig ordskifte med utgangspunkt i falsifisering av faktabaserte påstander og ekspertuttalelser.

Enkelte hevder at forskerne selv har bidratt til mistillit ved å gi feilslåtte råd, der de stadig skiftende ernæringsrådene er trukket frem som eksempel (Saltelli \& Funtowicz, 2017). På bakgrunn av en undersøkelse i 2017 anmodet direktør i Norges forskningsråd, John-Arne Røttingen, forskerne til å bli flinkere til å formidle kompleksiteten i sitt arbeid og hvilken rolle de har når de uttaler seg i media: Er de samfunnsdebattanter eller forskere?

Forskningens roller i samfunnet bør debatteres, og de etiske prinsippene og normene som skal verne om forskningens kvalitet og troverdighet, bør settes under lupen. Erfaringer fra NENT viser at på områder med sterke interessekonflikter aktualiseres klassiske forskningsetiske normer om åpenhet og uavhengighet. Sakene reiser også spørsmål om andre forskningsetiske normer som er formulert i Forskningsetiske retningslinjer for naturvitenskap og teknologi. Her kan nevnes krav om formidling av vitenskapelig usikkerhet og anvendelse av føre var-prinsippet. NENT ser et behov for mer diskusjon rundt disse normene. Dette behovet forsterkes i en tid der koblingene mellom akademia, næringsliv og politikk er tette, der det i stor grad stilles krav om at forskningen skal bidra til

2 Intervju med Per Sandberg i Bergens Tidende, mars 2016.

3 «Asylpolitikk uten dekning i vår forskning». Kronikk av Tine K. Jensen, Guro Brokke Omland, Nora Sveaas, Aftenposten, 6. april 2016.

4 «Et postakademisk universitet?» Kronikk av Dag O. Hessen i Morgenbladet, 6. mai 2016.

5 Røttingen i intervju med Aftenposten, 17. september 2017. 
å løse samfunnets utfordringer (Saltelli \& Giampietro, 2017), og der det forventes at interessegrupper tar del i forskningen. ${ }^{6}$

Slike krav og forventninger vektlegges i prinsippene for ansvarlig forskning og innovasjon (RRI, Responsible Research and Innovation), vedtatt av Europaparlamentet i 2014. Når samfunnsspørsmål er komplekse, er medvirkning i stor grad ønsket - fordi ulike aktører kan bidra med komplementære kompetanser og kunnskaper til forskning, aktuelle verdibetraktninger og nyttige relevansvurderinger. Dette kan igjen avstedkomme gode konsekvenser for individer, samfunn og miljø når forskningen tas i bruk. Samtidig kan et slikt samarbeid være sårbart for maktkamper og interessekonflikter. Involvering av berørte parter kan stå i motstrid til forskerens frihet og uavhengighet, hvis ikke forskeren selv skal ha siste ord i utformingen av forskningsprosessen. Forskerens valg av tilnærming, metode og analyse kan på sin side oppfattes å være spesielt gunstig for en bestemt interessepart.

Vi vil i det følgende gå raskt gjennom hvordan interessekonflikter i forskning gjerne avgrenses. Deretter presenterer vi forskningsetiske prinsipper og normer som er særlig aktuelle når interessekonflikter diskuteres, basert på utvalgte retningslinjer fra NENT (2016). Teksten danner en ramme for presentasjonen av bokas kapitler. Bidragsyterne i antologien belyser ulike sider ved interessekonflikter i forskning, der det fokuseres på de forskningsetiske spørsmålene.

\section{Interessekonflikter og interesseløse forskere}

Hva er så interessekonflikter i forskning? I denne antologien forstår vi interessekonflikter langs to linjer. For det første kan de omhandle habilitet hos enkeltforskere, for eksempel om forskeren har bindinger til forskningsmateriale eller oppdragsgiver på en måte som kan svekke det vitenskapelige arbeidet. En annen måte å forstå interessekonflikter er når politiske dragkamper utvikler seg til å bli debatt om kunnskapsgrunnlag og vitenskapelig metode, i et forsøk på å overbevise noen om hva som er en riktig politisk prioritering. Erfaringer fra NENT og samfunnsdebatten

6 Se for eksempel Langtidsplanen for forskning og høyere utdanning 2019-2028. 
viser hvordan ekspertkunnskap og faglige utredninger kan bli dreiepunktet for konflikt mellom ulike politiske eller økonomiske interesser. På den måten kan politiske saker flyttes over fra den politiske til den vitenskapelige arenaen - der enkelte forskningsprosjekter, -programmer, -metoder eller -resultater blir gjenstand for konflikt.

Interesseløshet (disinterestedness), formulert av Robert Merton (1942), er én av fire grunnleggende normer for god forskningspraksis. Normen er en essensiell del av forskningens etos og innebærer at forskeren ikke skal påvirkes av særinteresser, men kun styre sin virksomhet etter vitenskapelige interesser og sannhetssøken. Utgangspunktet er et ideal om at forskningsinstitusjoner og forskere kun har forsknings- eller kunnskapsinteresser, mens forskningsfinansiering kan være motivert av konkrete bruksinteresser, uavhengig av den mer forskningsinterne betydningen av slik kunnskap. 7 Dette er selvsagt en forenklet fremstilling, og de siste årenes debatt har vist at det gir lite mening $i$ å snakke om forskere og akademia som interesseløse i absolutt forstand. Aktører, inkludert forskere, har som regel flere interesser. Mange forskere er motivert til å løse samfunnsutfordringer, de er politisk interessert eller opptatt av at deres forskning skal bli brukt av samfunnsaktører. I slike situasjoner har forskeren eller forskningsinstitusjonen et ansvar for å overbevise sitt publikum om at forskningen ikke er utilbørlig påvirket av oppdragsgivernes interesser, men at den er til å stole på.

I kapittel 1 beskriver Nydal, Solberg og Myskja hvordan «interessekonflikter» $\mathrm{i}$ forskning viser til et ideal om interesseløshet. Forfatterne stiller et betimelig spørsmål om hvorvidt normen om interesseløshet fortsatt bør være sentral i forskningen i en virkelighet med utbredt samarbeid med private og offentlige aktører, og der nytteverdien av forskningen står sentralt. Gjennom kapittelet argumenterer de for at normen om interesseløshet først og fremst er en saksorientert forpliktelse, altså en forpliktelse til å innrette seg etter saken. Forskerne har derimot ikke noen forpliktelse til å unnga at samfunnsinteresser påvirker forskningen. Gitt denne forståelsen, er det fullt mulig og ønskelig å opprettholde normen om interesseløshet som et ideal. 


\section{Forskningsetiske retningslinjer \\ Forskningens uavhengighet og frihet}

Forskningens frihet og uavhengighet henger sammen med idealet om interesseløshet, og står helt sentralt i debatten om politisk styring av forskningsagendaen. I nasjonale forskningsetiske retningslinjer uttrykkes frihet først og fremst gjennom krav til uavhengighet fra eksterne interesser, forskernes rett til å velge metode og analyse, forskernes rett til tolkning og offentliggjøring og - på den andre siden - forskerens ansvar for å sikre faglig kvalitet og at forskningen skjer i tråd med etablerte normer. ${ }^{8}$ I kapittel 2 foreslår Gezelius og Mittenzwei en begrepsmessig avklaring av hva forskningsfrihet er. Det gjør de gjennom å skille mellom fire former for forskningsfrihet: temafrihet, kildefrihet, tolkningsfrihet og ytringsfrihet, hvor særlig den siste er i fokus. Forskningsfrihetene knyttes til ulike stadier i forskningsprosessen, belyses ut fra funksjonene de fyller, og argumenteres for at de i ulik grad er fravikelige. Et sentralt spørsmål er hvordan forskningsfrihet kan beskyttes når parter med særinteresser kjemper om allmennhetens virkelighetsoppfatning. Forfatterne har selv bakgrunn fra instituttsektoren, og argumenterer for at den i større grad må realisere og forsvare sin faglige nøytralitet. Offentlige myndigheter bør på sin side tydeliggjøre sitt hittil uklare krav om akademisk frihet for forskere i instituttsektoren, sier de.

Med utgangspunkt i Forskningsetiske retningslinjer for naturvitenskap og teknologi mener vi at forskernes og forskningsinstitusjonenes uavhengighet kan forstås på to plan:

a) Uavhengighet $i$ betydningen selvstendig ansvar for egen rolle $i$ samfunnsutviklingen. ${ }^{9}$

For det første handler uavhengighet om forskningsinstitusjonenes og forskernes ansvar for å reflektere over egen rolle som kunnskapsprodusent $\mathrm{i}$ et overordnet, helhetlig og lengre perspektiv. I lys av et omfattende

8 Forskningsetiske retningslinjer for naturvitenskap og teknologi, særlig punkt 17 og 18, NENT (2016).

9 Forskningsetiske retningslinjer for naturvitenskap og teknologi, punkt 1, NENT (2016). 
samarbeid med industrien, eller sterke forskningspolitiske føringer, er det særlig viktig med refleksjon rundt egen rolle i samfunnsutviklingen samt eventuelle bindinger til samarbeidspartnere. Dette kan bidra til uavhengighet $\mathrm{i}$ den forstand at det tas selvstendig ansvar i forbindelse med valg av problemstillinger og tematisk utforming av forskningen. Slike refleksjoner er nødvendige dersom man skal ivareta forskningens iboende verdi og forskningen som et fritt, kritisk og viktig korrektiv til samfunnets utvikling.

b) Uavhengighet i metodevalg, datainnsamling, analyse og tolkning.

For det andre handler det om uavhengighet i selve gjennomføringen av forskningen. I flere saker i NENT har det oppstått usikkerhet om oppdragsgivers eller industriens rolle i forskningsprosessen, og hvordan dette har påvirket resultatene. Forskningsetiske retningslinjer for naturvitenskap og teknologi fremhever at det ved oppdragsforskning vanligvis er oppdragsgiver som bestemmer tema og problemstillinger i idéfasen, mens forskeren har ansvar for spørsmål knyttet til metode, datainnsamling og tolkning av resultater, og - mer overordnet - et ansvar for å sikre vitenskapelig kvalitet. Disse spørsmålene bør vurderes uavhengig av eksterne bindinger. ${ }^{10}$

Selv om forskningens uavhengighet er forholdsvis lett å snakke om, er den vanskeligere å praktisere. Det kan ofte oppstå tvilstilfeller og spørsmål om grensen mellom akseptabel kvalitetssikring fra oppdragsgivers side og utidig innblanding. Dette kan dreie seg om i hvilken grad forskeren bør påpeke eventuelle mangler i tematisk innretning av et prosjekt, og i hvilken grad oppdragsgiver har legitime innspill i metodevalg eller i tolkningen av resultater. Forskeren må vurdere om eget valg av tema, metode, teoretiske tilnærminger og tolkninger av resultater kan favorisere visse interesser eller interessenter. I kapittel 9 viser Gaarder og Wangen hvordan metodiske veivalg i kartlegging og verdisetting av naturtyper er uløselig knyttet til diskusjonen om politiske mål for bevaring av biologisk mangfold. Samtidig står nøytralitet og uavhengighet 
sentralt i samfunnets forventninger til ekspertkunnskap i en miljøplanlegging. En rigid forståelse av disse prinsippene er lite uttalt, og forfatterne etterlyser en åpen diskusjon om faglig usikkerhet og bruk av skjønn i ekspertutredninger. På den måten skapes en situasjon der metodens presisjon og evne til å favne naturtypenes nyanser og dynamikk ikke blir diskutert, ei heller forbedret.

I kapittel 7 beskriver Andersen kravet om vitenskapelig konsensus i arbeidet med å utrede en helhetlig forvaltningsplan for Barentshavet. Kritikk og faglig uenighet er viktige forutsetninger for vitenskapelige fremskritt, og det er et typisk kjennetegn ved akademia at forskerne gjerne har ulike svar og betraktninger rundt samme type spørsmål. I langsiktige planprosesser på nasjonalt nivå er det imidlertid vanlig at ekspertene blir bedt om å samle seg rundt en felles konklusjon, som så overleveres til myndighetene. Spørsmålet som stilles, er derfor om kravet til konsensus utfordrer den faglige uavhengigheten, ettersom ekspertene i stedet må fremstå samstemte i komplekse spørsmål med stor grad av usikkerhet.

\section{Usikkerhet, risiko og føre var-prinsippet}

Når det gjelder selve bruken av forskningsresultatene, fremhever forskningsetiske retningslinjer at forskere har et ansvar for å bidra med relevant kunnskap. ${ }^{11}$ Men forskning gir ikke nødvendigvis sikker kunnskap eller entydige svar. Formidling av vitenskapelig usikkerhet og risiko samt anvendelse av føre var-prinsippet er særlig viktig i interessekonflikter. Disse prinsippene skal stimulere til at forskningsresultatenes styrker og svakheter blir formidlet på en forståelig måte, og at føre var-prinsippet brukes i relevante sammenhenger. Det er en del av forskerens ansvar å anerkjenne og formidle den usikkerheten forskningen er beheftet med, og hvilke konsekvenser denne usikkerheten kan ha for hvordan kunnskapen skal forstås. Fordi føre var-prinsippet er et forvaltningsprinsipp, kreves kunnskap og erfaring fra forskere så vel som bidrag fra forvaltning og politiske beslutningstakere når det skal operasjonaliseres. Kapittel 5 av Bjørkan og Hauge handler om utfordringer knyttet til vitenskapelige

11 Forskningsetiske retningslinjer for naturvitenskap og teknologi, punkt 8 og 9, NENT (2016). 
resultater og iboende usikkerhet, der temaet er lakselusas påvirkning på villaks. Her får vi se hvordan kvalitet i forskning blir gjenstand for konflikt mellom oppdrettsinteresser og miljøinteresser. Forfatterne problematiserer hvilken rolle usikkerheten spiller i kunnskap om lakselus ved å diskutere dette i forskningsetiske perspektiv: formidling av usikkerhet, føre var-prinsippet, kvalitet i forskning og brukermedvirkning.

I kapittel 11 argumenterer Samset for en ny type forskningsformidling. Bakgrunnen er fremveksten av «postfakta» eller avvisning av vitenskapelig kunnskap. Stadig oftere synes forskere å bli avvist i offentlig debatt til fordel for subjektive meninger, hevder Samset, særlig på felt der sterke interesser er involvert, som vaksineforskning og klimaforskning. Samset mener forskningsformidling i større grad bør kjennetegnes av stikkordene «styrke» og «veiledning». «Styrke» fordi det er behov for å gjenta resultater flere ganger, samt understreke hva vitenskapen regner som etablerte sannheter, og hva som er mer usikkert. «Veiledning» innebærer at forskere i dag må skissere handlingsvalg ut fra tilgjengelig forskning og de utfordringer samfunnet står overfor, mens valgene i neste runde må tas av politiske beslutningstakere.

\section{Åpenhet}

Som forskningsetisk prinsipp er åpenhet sentralt for å bevare vitenskapens uavhengighet. Åpenhet har flere dimensjoner. Dels er det et krav om å være åpen om mulige interessekonflikter, og dels er det et krav om å redegjøre for relasjoner og interesser som kan påvirke de vurderinger som skal gjøres, det vil si krav knyttet til habilitet. ${ }^{12}$ I kapittel 8 uttrykker Aas en bekymring for manglende åpenhet i de formelle rollene til aktører i konsekvensutredninger. For eksempel påpeker han at tiltakshaver selv har ansvar for de faglige utredningene i dag. Aas viser hvordan ulike interesser kan påvirke prosesser i konsekvensutredninger, slik at det kan reises spørsmål om deres åpenhet, kvalitet, uavhengighet og legitimitet. Videre viser han hvordan roller i konsekvensutredninger har endret seg over tid.

12 Forskningsetiske retningslinjer for naturvitenskap og teknologi, punkt 18, NENT (2016). 
Åpenhet innebærer også et forskningsetisk krav om at forskningsresultater, metoder og data deles og offentliggjøres, både for å legge til rette for kvalitetssikring og for at resultater kommer samfunnet til gode. De siste årene har dette også blitt et forskningspolitisk krav. ${ }^{13}$ I kapittel 3 gir Braarud Hanssen innsyn i en praksis det snakkes relativt lite om, men som brer om seg innenfor stadig flere forsknings- og teknologifelt, nemlig patentering. Han diskuterer ulike forskningsetiske spørsmål som oppstår med patentering. Åpenhet, i den forstand at forskersamfunnet fritt skal kunne dele og ha tilgang på all kunnskap som blir produsert til fellesskapets beste, er i direkte konflikt med patentsystemets normative grunnlag, påpeker han. Men åpenhet handler også om å sikre åpenhet og oversikt over områder for forskningsinnsats, inkludert omfang og betydning, for å bidra til en bred offentlig debatt om prioritering av forskning og teknologiutvikling. Braarud Hanssen viser at det også i den forstand er store utfordringer med dagens patentpolitikk og -praksis.

\section{Forskningens samfunnsansvar}

Det neste forskningsetiske prinsippet handler om at forskningen skal komme samfunnet til gode, og at den ikke skal gjøre skade. ${ }^{14}$ Det er ikke opplagt hva det betyr i praksis. I forskningspolitikken kan vi se tendenser til at det settes likhetstegn mellom forskningens nytteverdi og dens innovasjonspotensial, og kommersielle nytteverdi. I revidert Langtidsplan for forskning og høyere utdanning 2019-2028 (Meld. St. nr. 4 (2018-2019)) er vektleggingen av forskningens nytteverdi fremtredende. Kravet om nytteverdi finner vi igjen i strategien fra Norges forskningsråd, Forskning for innovasjon og borekraft (2015), der det fremheves at forskningen skal gi resultater som kan anvendes i næringsliv, offentlig sektor og i

13 Norges forskningsråd har sammen med en rekke andre europeiske forskningsråd, Europakommisjonen og det europeiske forskningsrådet (ERC) gått inn for å kreve full åpen tilgang til alle artikler fra forskning som er finansiert av disse landene og institusjonene fra 2020. Regjeringen har lagt frem en nasjonal strategi for tilgjengeliggjøring og deling av forskningsdata. Rådet for den europeiske unionen (Ministerrådet) har vedtatt en rekke prinsipper for åpen forskning (Open Science), som stiller sterkere krav til åpen tilgang til forskningsdata fra prosjekter som får finansiering fra EU.

Forskningsetiske retningslinjer for naturvitenskap og teknologi, punkt 1, NENT (2016). 
politikkutviklingen. Dette gjenspeiles også i verdens største forskningsprogram, H2O2O - The EU Framework Programme for Research and Innovation. Samtidig er det viktig å ha en levende diskusjon om hvem som egentlig definerer nytte, og hvordan nytte forstås - på lang eller kort sikt - og for hvem.

I kapittel 4 retter Skogen, Ruud og Krange sterk kritikk mot det de mener er en dreining i norsk forskningspolitikk mot private næringsinteresser. Dette innebærer en altfor snever forståelse av hva som er samfunnsnyttig, ifølge forfatterne, som etterlyser mer forskning som er kritisk til samfunnsutviklingen, og som argumenterer for at dette kan oppnås gjennom å gi mer rom til fri og uavhengig forskning i Forskningsrådets programplaner.

En av retningslinjene til NENT sier at forskning skal være i overenstemmelse med bærekraftig utvikling. ${ }^{15}$ Dette kan sees som et prinsipp om at nytten i forskningsprosjekter ikke skal gå på akkord med verdier som sosial urett og miljø. I Norge skal forvaltning av naturressurser være bærekraftig, og nettopp fortolkninger av bærekraft danner bakteppe for en rekke konflikter. Denne boka tar for seg noen av disse konfliktene. For eksempel kan uenigheten om hvor iskanten i Barentshavet befinner seg (Bay-Larsen et al., kapittel 6), relateres til hva som er akseptabel risiko for miljøet. Andre kapitler (Myklebust, kapittel 10; Bjørkan \& Hauge, kapittel 5) reiser spørsmål om lakseoppdrett er bærekraftig drevet. Flere av sakene NENT har fått på bordet de siste årene, kan knyttes til liknende uenigheter om bærekraft, der det har vært uttrykt bekymring for at uavhengighet og kvalitet ikke er ivaretatt i oppdragsforskning eller forskningsprosjekter, ${ }^{16}$ med den konsekvens at det ikke er tatt tilstrekkelig hensyn til miljøet.

I kapittel 10 viser Myklebust hvor krevende det kan være for forskere å ta det ansvaret det er å formidle samfunnsaktuell forskning om konfliktfylte tema. Hun beskriver hvordan villaksforskerne ved Havforskningsinstituttet og Norsk institutt for naturforskning møtte mer enn faglig motstand for sine rapporter og publikasjoner, og der det offentlige

15 Forskningsetiske retningslinjer for naturvitenskap og teknologi, punkt 2, NENT (2016).

16 Se uttalelser fra NENT på www.etikkom.no 
ordskiftet i økende grad fokuserte på enkeltforskere og deres arbeid over tid. Forskningsinstituttene opplevde dette som hets og sjikane, med det klare formål å styrke legitimiteten til akvakulturnæringen gjennom å dekonstruere den vitenskapelige troverdigheten til villaksforskerne.

\section{Avsluttende refleksjoner}

Erfaringer fra komiteene de siste årene viser at det kan være uklart når normene som diskuteres i denne antologien, er aktuelle, og hva de betyr. Anerkjente forskningsetiske normer, uttrykt gjennom de nasjonale forskningsetiske retningslinjene, gjelder for all forskning i privat og offentlig regi. ${ }^{17}$ Men begrepet "forskning» gis noe ulikt innhold i ulike lovverk og sektorer, og det kan et oppstå kompliserte grensedragninger ved hybride former for kunnskapsproduksjon, som for eksempel utredninger og evalueringer. Vi forsøker ikke å gi et fasitsvar på spørsmålet om hvor grensene går i denne antologien, men fastholder at det er viktig med diskusjon og åpenhet rundt hva som er forskning og ikke, og hva som utgjør «anerkjente forskningsetiske normer». Vi håper og tror at bidragene i denne boka er med på å løfte frem disse problemstillingene til refleksjon og debatt. Dette er en vitenskapelig antologi, hvor alle kapitler, med unntak av kapittel 4, 10 og 11, er vurdert av ekstern fagfelle.

\section{Referanser}

Bergens Tidende (2016, mars). Intervju med Per Sandberg.

Hessen, D.O. (2016, 6. mai). Et postakademisk universitet? Morgenbladet, Oslo.

Jensen, T.K., Omland, G.B., \& Sveaas, N. (2016, 6. april). Asylpolitikk uten dekning i vår forskning. Aftenposten, Oslo.

Kunnskapsdepartementet. Langtidsplan for forskning og høyere utdanning 2019-2028 (Meld. St. nr. 4. (2018-2019)). Oslo: Kunnskapsdepartementet.

Merton, R.K. (1942). The Normative Structure of Science (1942). I Merton (1973, red.), The Sociology of Science: Theoretical and Empirical Investigations, Chicago: University of Chicago Press.

17 Formålsbestemmelsen i Lov om organisering av forskningsetisk arbeid (forskningsetikkloven), $\$ 1$. 
NEM, NENT, NESH (2003). Oppdragsforskning: åpenhet, kvalitet, etterrettelighet. Oslo: Forskningsetiske komiteer.

NENT (2016). Forskningsetiske retningslinjer for naturvitenskap og teknologi. Oslo: De nasjonale forskningsetiske komiteene.

Norges forskningsråd (2015). Forskning for innovasjon og boerekraft. Strategi for Norges forskningsråd 2015-2020. Oslo: Norges forskningsråd.

Prop. 158 L (2015-2016). Lov om organisering av forskningsetisk arbeid (forskningsetikkloven). Oslo: Kunnskapsdepartementet.

Saltelli, A., \& Funtowicz, S.O. (2017). What is science's crisis really about? Futures, 91: 12-24. http://dx.doi.org/10.1016/j.futures.2017.05.010

Saltelli, A., \& Giampietro, M. (2017). What is wrong with evidence based policy, and how can it be improved? Futures 91: 62-71. https://doi.org/10.1016/j.

futures.2016.11.012 


\title{
Interessekonflikter i forskning: Om forskningens saksorienterte forpliktelse
}

\author{
Rune Nydal
}

Førsteamanuensis, Institutt for filosofi og religionsvitenskap, NTNU

\section{Berge Solberg}

Professor, Institutt for samfunnsmedisin og sykepleie, NTNU

\section{Bjørn Myskja}

Professor, Institutt for filosofi og religionsvitenskap, NTNU

\begin{abstract}
Researchers are increasingly challenged to adjust to interests defined outside their own disciplinary boundaries. This follows from more or less explicit expectations to seek interdisciplinary collaboration and partnership within the private and public sectors. How can researchers identify and handle conflicts of interest in this situation? To answer this question, we first defend the validity of the traditional ideal of disinterested research. This ideal still provides a key guideline for identifying conflicts of interest in research: the freedom of research. This freedom should not, however, be misunderstood as disciplinary confinement or as freedom to ignore societal interests. We suggest that the crucial issue is the freedom and duty to be oriented towards the subject matter itself.
\end{abstract}

Keywords: disinterested research, interdisciplinarity, CUDOS, Mode 2, internalism

Sitering av dette kapitlet: Nydal, R., Solberg, B., \& Myskja, B. (2019). Interessekonflikter i forskning: Om forskningens saksorienterte forpliktelse. I H. Ingierd, I. Bay-Larsen \& K. Hiis Hauge (Red.), Interessekonflikter iforskning (s. 19-43). Oslo: Cappelen Damm Akademisk. https://doi.org/10.23865/noasp.63.ch1 Lisens: CC BY 4.0 


\section{Interesseløs forskning: Hva kan det bety $i$ dagens forskningsvirkelighet?}

Forskning skal og bør være interesseløs ${ }^{1}$. Interesseløshet er en av de fire sentrale normene for god forskningspraksis, ifølge Robert Merton. Selv i dag vil alle forskningsinstitusjoner på papiret bekjenne seg til et verdigrunnlag hvor dette står sentralt. Men virkeligheten synes å ha blitt en annen. Nye ph.d.-studenter i medisin og teknologi møtes ofte med innføringskurs i patentering. Industrisamarbeid hører med når man søker Forskningsrådet om midler. Nært samarbeid med oppdragsgivere utgjør hverdagen for en stadig større andel av forskere. Til og med klassiske kritiske fagområder som samfunnsfag og humaniora dras inn i flerfaglige samarbeid hvor de blir beskyldt for å fungere som smøremiddel for biomedisinske særinteresser. Interesseløshet er ikke lenger det mest iøynefallende trekket ved forskningens vesen. Snarere tvert imot. I en slik ny virkelighet må man avklare hva som egentlig ligger i begrepene «interessekonflikt» og «interesseløshet». Er det fremdeles mulig å mene at interesseløshet er og bør være en sentral norm i forskningen, eller har idealet utspilt sin rolle? I denne artikkelen forsvarer vi interesseløshetsidealet. Vi argumenterer for at interesseløshet ikke bør forstås som en fagorientert, men snarere som en saksorientert forpliktelse. Det er forskningens frihet til å innrette seg etter saken vi må verne om, og ikke primært forskningens frihet fra forventninger om samfunnsnytte. Gjennom eksempler viser vi hvordan dette er mulig.

\section{Interessekonflikter og idealet om den interesseløse forskning}

Interessekonflikter kan oppstå i alle profesjoner. Det foreligger en konfliktsituasjon dersom profesjonsutøvelsen kan bli kompromittert, eksempelvis uttrykt i Dennis Thompson mye refererte definisjon: «A conflict of

«Interesseløs» er en oversettelse av det engelske «disinterested», som inngår i Mertons sett av vitenskapelige normer (se nedenfor). Vi har valgt dette ordet fremfor alternativene «nøytral» og «upartisk» (Kaiser, 2015) fordi det er en direkte oversettelse av Mertons begrep, og fordi alternativene har flere betydninger og må derfor avgrenses om de skal benyttes her. Videre er vårt primære tema interessekonflikter, og derfor er det også tjenlig å bruke en oversettelse som inneholder termen «interesse». 
interest is a set of conditions in which professional judgment concerning a primary interest [...] tends to be unduly influenced by a secondary interest» (Thompson, 1993: 573). Det handler om vern av profesjonens primære formål, det profesjonen tjener til. En profesjon har en samfunnsoppgave utøverne skal være tro mot. Leger, for eksempel, som Thompson diskuterer, skal ha pasientens velferd for øye. Forskere skal være tro mot sine primære oppgaver - som å avdekke sannhet, opparbeide ny kunnskap samt identifisere, analysere og løse problemer.

Løsning av slike oppgaver er i utgangspunktet - og ideelt sett - forskerens eneste interesse som forsker, selv om vi senere skal diskutere modifikasjoner til dette utgangspunktet. Men forskere er mennesker med mange andre interesser, som vi kan kalle sekundære i denne sammenhengen. Interessekonflikter handler om situasjoner der det kan oppstå konflikt mellom primære og sekundære interesser. Slike situasjoner skal unngås både fordi den profesjonelle dømmekraften kan påvirkes eller svikte, men også fordi resultatene kan bli trukket i tvil - med rette eller urette. Fordi forskningens integritet settes på spill, har identifisering og håndtering av slike konfliktsituasjoner vært en av forskningsetikkens mest sentrale oppgaver.

Forskningens integritet er avgjørende enten forskerne hevder å ha et nytt kunnskapsbidrag, legger frem et forslag til problemløsning, utarbeider en kritikk av kollegers argumentasjon eller forhandler frem en avtale med et privat eller offentlig foretak. Det forskningsetiske spørsmålet om interessekonflikter handler om å identifisere hvilke kritiske situasjoner forskere kan oppleve, og hvordan disse bør håndteres. Det handler også om å identifisere situasjoner hvor den profesjonelle dømmekraften er spesielt sårbar, og at resultater derfor også kan bli trukket i tvil, selv om dømmekraften faktisk ikke ble påvirket. Forskningen skal beskyttes mot, og enkeltforskere skal forskånes fra, å havne i slike situasjoner. Forskersamfunnet har derfor rutinemessige diskusjoner om habilitet og om hvilke sekundære roller og interesser forskere plikter å skape åpenhet om.

\section{Cudos og etos - barn av en annen tid?}

IMertons (1942) innflytelsesrike analyse avvitenskapens etos, oppsummert i akronymet «cudos», står normen om interesseløshet (disinterestedness) 
sentralt. «Cudos» er også et gresk honnørord som betegner allment kjente og anerkjente trekk ved en person eller ved en institusjon. Det handler om det som danner grunnlag for berømmelse og som fremstår som et tydelig karakteristisk trekk. Analysen er at de karakteristiske trekk Merton identifiserer (communism, universalism, disinterestedness og organised scepticism) verdsettes fordi de samlet sett uttrykker vitenskapens etos. Etos er et moralsk begrep, som i dette tilfellet ikke først og fremst refererer til enkeltforskerens, men snarere til institusjonens moralske karaktertrekk som tillitsverdige og sannferdige. Interesseløshet er da ett av fire gjenkjennelige trekk ved vitenskapene som Merton samtidig formulerer som normer forskere skal etterstrebe. Forskere skal være interesseløse, ettersom betingelsene for produksjon av pålitelig kunnskap står på spill.

Utfordringen i dag er at interesseløshet fremstår som et langt mindre gjenkjennelig trekk ved forskningen enn for sytti år siden, da Merton skrev sine tekster. Dette er ikke spesielt nytt. Det er mer enn tjue år siden John Ziman (1996: 751) nettopp stilte spørsmålet i tidsskriftet Nature - om forskere virkelig kan forventes å være objektive i en verden der forskningen i økende grad er rettet mot produktivitet eller mot å imøtekomme samfunnets behov. Mertons norm uttrykker en forventning om at forskningen skal være upåvirket av særinteresser av politisk og økonomisk karakter, så vel som av forskernes private oppfatninger og fordommer. Den skal være objektiv, upartisk og nøytral. Men den forventningen synes å stå i direkte motsetning til kravet om samfunnsnytte. Med andre ord, trues forskningens egenart, dens mulighet til å oppfylle sine primære oppgaver, av ønsket om økt samfunnsnytte? Om så er tilfelle, vil det bety at det er noe galt med vitenskapen slik den organisatorisk har utviklet seg - slik vi gjenkjenner og vel også anerkjenner den i dag?

En annen mulighet er at Merton bommet, eller ikke helt hadde utviklet sine ideer godt nok, når han vektla interesseløshet som et så definerende karaktertrekk ved forskergjerningen. Vi tror ikke det. Som Ziman (2002) senere også foreslo, kan den økte tematiseringen av og bekymringen for vitenskapelige interessekonflikter - slik det for øvrig også kommer til uttrykk i denne antologien - forstås som et uttrykk for at interesseløshet fremdeles står sterkt som ideal. Problemet ligger ikke så mye i Mertons 
begrep om interesseløshet, som er et rikere begrep enn det ofte fremstilles som. Utfordringen ligger snarere i å forstå hvordan man sikrer interesseløsheten i dagens forskningsvirkelighet.

\section{Hva menes egentlig med interesseløs forskning?}

La oss se nærmere på sammenhengen mellom interesseløshet og pålitelighet. Den har stått - og bør etter vår mening fremdeles stå - sentralt for spørsmålet om hvordan vi skal forstå hva som står på spill i interessekonflikter. Historikeren Yuval Noah Harari har beskrevet moderne vitenskap som den første kunnskapstradisjonen i verden som har innrømmelsen av uvitenhet som sitt fremste kjennetegn (Harari, 2016: 243-250). Mens alle andre kunnskapssystemer (inkludert religionene) har hevdet å ha svarene på livets og universets viktigste spørsmål, er vitenskapens utgangspunkt at alle svar er foreløpige, begrenset av vår uvitenhet, og at vi må forske mer for å komme videre. Vi skal ikke gå god for Hararis religionsanalyse, men ta utgangspunkt $i$ hans beskrivelse av gjenkjennelige og etterstrebelsesverdige trekk ved vitenskapen. I sitt forsøk på en ny gjennomgang av vitenskapshistorien skriver Hariri seg inn i en poppersk tradisjon som identifiserer og verdsetter den vitenskapelige holdningen som fallibilistisk: Den vet at den kan ta feil. Denne holdningen henger sammen med idealet om interesseløshet. Forskernes interesser er ikke bundet til svarene, og forskerne er dermed ikke interessemessig bundet til å forsvare sine svar. For er det ikke slik at de vi vil peke på som forbilledlige forskere, er de som preges av en åpenhet for at de kan ta feil og er genuint interessert i motargumenter?

Paradokset er imidlertid at så lenge forskeren ikke interessemessig er bundet til svarene vedkommende gir på de spørsmålene forskeren selv anser som avgjørende å stille, har man å gjøre med en interesseløs interesse. Vitenskapen er interesseløs såfremt den besinner seg på de interesser den selv er drevet av. Det er denne dobbeltheten som muliggjør at vi kan kalle vitenskap interesseløs, selv om vi er motivert til, og dermed i høyeste grad interessert i, å drive med den. Vi kan si at idealet om «interesseløs» forskning betyr forskning drevet av interesse for dens 
primære oppgaver. En slik interesseløs interesse kan dermed også kalles en primorinteresse.

Sekundærinteressen er ikke problematisk i og for seg, bare dersom den svekker primærinteressen. Vi kan litt enkelt si at den gode interessen er en interesse for sannheten. Den problematiske interessen handler om alt det andre som kan drive oss og sette oss i konflikt med sannhetsforpliktelsen, for eksempel økonomiske interesser knyttet til et bestemt forskningsresultat. Vi gjenkjenner dette skillet når interessekonflikt blir diskutert i litteraturen: «A disinterested researcher is motivated by curiosity, pursuing knowledge for its own sake, and is more interested in the rewards of intellectual discovery than in personal gain» (Tobin, 2003: 1161). Betoningen av det nysgjerrighetsdrevne, eller det vi kan omtale som det akademiske driv, treffer noen viktige og gjenkjennelige sentrale trekk ved forskningen.

Ideen om at den ideelle forskermotivasjonen kan beskrives som en interesseløs interesse, har støtte i en gammel filosofisk tradisjon. Aristoteles fremhever det teoretiske studiet av den uforanderlige verden som den fremste menneskelige aktivitet, fordi den utelukkende ble gjort for sin egen skyld. Den var altså ikke drevet av noen interesse utenfor seg selv, og ble dermed den fremste aktiviteten nettopp fordi den er interesseløs. Når Kant beskriver menneskers engasjement i den grunnleggende estetiske erfaring, betegner han det som en interesseløs interesse (Kant, 1987). Han kontrasterer det med interesse i det behagelige eller i det gode, som enten er interesse i å fremme egen eller andres velferd, eller er interesse knyttet til moralske eller religiøse ideal. Det vitenskapelige idealet om forskning for forskningens skyld uttrykker altså en veletablert idé om forskning som en aktivitet som utelukkende utøves for sin egen skyld, ikke for å fremme velferd, øke status eller å virkeliggjøre en moralsk, politisk eller religiøs idealtilstand.

\section{Kollektiv interesseløs interesse}

Den interesseløse interessen blir mindre abstrakt når vi forstår den som en interesse formet og definert av et kollektiv. Den primære interessen retter forskeren mot det som har forskningsinteresse, altså det et fellesskap 
av forskere vil være enige om er verdt å oppnå. Forskerens interesse er noe vedkommende deler med andre forskere, eller evner å skape en delt interesse for. Det handler om en felles interesse for saken, enten det er ideer, et objekt eller et problem. Denne interessen kan også være betinget av materielle forhold, av hva som er mulig gitt eksisterende teknologi, datakraft og forskningsinfrastrukturer, et tema vi kjenner igjen fra vitenskapsteoridiskusjoner på åtti- og nittitallet (se f.eks. Hacking, 1983; Pickering, 1992; og Knorr-Cetina, 1999). Sann forskning er bare sann forskning om den lever opp til kvalitetsstandarder som er etablert og kontinuerlig justert over tid blant forskere som stadig utvikler nye sosiale og teknologiske plattformer for sin aktivitet. Den interesseløse interessen knyttes her til en forpliktelse på forskerkollektivets interesse for saken. En saksorientert forpliktelse fordrer en pågående diskusjon om god forskningspraksis, ettersom saken selv ofte er materielt og sosialt betinget. Det er slik vi forstår Knut E. Tranøy når han beskriver vitenskapen som en normstyrt aktivitet med sannhetsforpliktelsen som normsystemets «basale, eller konstitutive, verdi» som andre metodologiske normer utledes fra (1986: 146).

En kilde til misforståelse, som Merton diskuterer, er at vi forstår kjærlighet til sannheten som et grunnleggende trekk ved - eller krav til - den individuelle forskerens karakter. Når forskningen har lyktes så godt med å holde høye forskningsetiske standarder, argumenterer Merton, skyldes det ikke at forskerne har høyere moralske standarder enn andre mennesker. Det er snarere slik at de har klart å bygge forskningsinstitusjoner som har mekanismer som sikrer at det ikke oppstår konflikt mellom en individuell og en kollektiv interesse. Institusjonen belønner adferd der vitenskapsfolk ikke handler i egeninteresse. Eller sagt på en annen måte: Gjennom institusjonelle strukturer blir det i forskerens egeninteresse å handle uegennyttig. Forskerne kan handle interesseløst, ikke først og fremst gjennom moralsk styrke, men snarere gjennom institusjonell organisering. Merton formulerte det slik:

A passion for knowledge, idle curiosity, altruistic concern with the benefit to humanity and a host of other special motives have been attributed to the scientist. The quest for distinctive motives appears to have been misdirected. It is rather a distinctive pattern of institutional control of a wide range of motives which characterizes the behavior of scientists. For once the institution enjoins 
disinterested activity, it is to the interest of scientist to conform on pain of sanctions and, in so far as the norm has been internalized, on pain of psychological conflict. (Merton, 1942: 276. Vår utheving)

Det handler altså ikke så mye om den interesseløse forskeren som om det interesseløse forskerfellesskapet. Forskeren taler med legitim autoritet om et saksområde, såfremt vedkommende uttaler seg på vegne av et vi. Vi har grunn til å feste lit til forståelser av et saksområde som over tid har stått seg mot utprøving og kritikk av et kollektiv av saksorienterte forskere. Det sentrale her er at forskyvning fra individuell til kollektiv sannhetsforpliktelse retter oppmerksomheten mot prinsippet om forskningens frihet eller forskningsinstitusjonens autonomi. Det er forskerfellesskapets sannhetsforpliktelse, utmyntet i et sett av metodologiske normer, som vernes gjennom institusjonell selvorganisering. Vitenskapens etos, institusjonens moralske karaktertrekk som sannhetssøkende aktivitet, vil dermed være sårbar for økonomiske, religiøse eller statlige interesser som kan undergrave forskningens frihet. Samtidig forutsetter denne institusjonelle etos at de enkelte forskerne deler dette moralske idealet og bidrar aktivt til å opprettholde en sannhetsorientert kultur.

Det er mot denne bakgrunnen vi forstår viktigheten av normen om interesseløshet, og viktigheten av å være oppmerksom på interessekonflikter. Forskningsinstitusjoner er sårbare, og en kan ikke ta for gitt at idealer for god praksis internaliseres og opprettholdes. Som et ledd i dette vernet av forskerkulturen, argumenterer Merton, må forskere få hjelp til å rette oppmerksomheten mot forskningen selv, for slik å unngå de sårbare situasjonene som kan oppstå når en underlegges interesser utenfra eller forskningseksterne egeninteresser:

[T] he social stability of science can be ensured only if adequate defenses are set up against changes imposed from outside the scientific fraternity itself [...] This process of preserving institutional integrity and resisting new definitions of social structure which may interfere with the autonomy of science finds expression in yet another direction. [...] One sentiment which is assimilated by the scientist from the very outset of his training pertains to the purity of science. Science must not suffer itself to become the handmaiden of theology or economy or state. (Merton, 1938: 259) 
I et velfungerende forskningssystem er standarder for god forskningspraksis underlagt institusjonell kontroll gjennom et normsystem internalisert av de enkelte forskerne. Men dette systemet er sårbart for interessekonflikter. Forsvarsstrategien, som forskere har utviklet sterke tradisjoner for, består i å ikke utsette enkeltforskere eller forskerinstitusjoner for situasjoner som kan medføre interessekonflikt. Denne forsvarsstrategien uttrykkes sterkt - som et forbud. Dette handler om situasjoner en rett og slett ikke skal gå inn i, og ved tvil plikter å opplyse om. Alt annet er brudd på god forskningsskikk. Når vi snakker om interessekonflikt, skal vi være forsiktig med å tenke for fort i retning av illegitime og legitime interesser. Økonomiske, politiske eller religiøse interesser er ikke i seg selv illegitime som interesser for forskningen. Poenget er at de må forstås og behandles som sekundære interesser: De skal ikke komme i førersetet på måter som gjør at primærinteressen forstyrres.

\section{Interesseløshet og skepsisen til nytteetiske vurderinger}

Fokusering på interessekonflikter er sentralt i dagens forskningspraksis, og forskere vender stadig tilbake til den mertonianske begrunnelsen. Stine Djørup og Klemens Kappel har eksempelvis nylig argumentert for at det er ikke fraværet av interesser som kjennetegner den interesseløse forskeren, men snarere fraværet av det som kan skade eller ødelegge selve forskningsprosessen:

[...] according to this interpretation the norm of disinterestedness does not prohibit the existence of interests of scientists tourt court, but rather certain forms of corrupting influence on the research process. (Djørup \& Kappel, 2013)

Den konstruktive fortolkningen av interesseløshetsidealet, hevder de, er å koble det til begrepet reliabilitet eller pålitelighet. Den interesseløse forskeren kjennetegnes ikke av et fravær av interesser, men snarere av at vedkommende ikke tillater andre interesser (det vi har kalt sekundærinteresser) enn «interessen» i å frembringe pålitelig og troverdig kunnskap: 
The disinterested scientist is not someone who is indifferent to research interests, scientific significance, financial or social rewards, social consequences or the like. She is simply someone who does not let these interests interfere with the ability to produce reliable claims about the world. (Djørup \& Kappel, 2013)

Her oppstår imidlertid en fare for en annen misforståelse. Dersom dette vernet uttrykkes som et ideal om «forskning for forskningens skyld», som det eksempelvis uttrykkes i sitatet vi hadde fra Tobin, kan veien være kort til et ideal om en forskningspolitikk blindet for nytteaspekt. Gjentatte formaninger om at forskning kun skal være nysgjerrighetsdrevet, kan ha gitt næring til en ryggmargsrefleks mot ordet nytte. Som om det skulle være en fornærmelse av forskningens etos å spørre en forsker hva forskningen er godt for. Forskere kjennetegnes av en dyp skepsis til nytteetisk vurdering av forskning, sier Merton. Dette kommer til uttrykk i historier som sirkulerte om en middagsskål blant matematikere i Cambridge: «To pure mathematics, and may it never be of any use to anybody» (1938: 260).

Det Merton synes å advare mot, er tanken om at interesseløshet uttrykker et ideal om at forskning fremstår på sitt beste når den ikke er rettet mot noe utover seg selv, det vil si forskningens eget fagfellesskap med dets selvregulerende dynamikk. Idealet om det interesseløse forskerfellesskapet kan dermed fort bli forstått som en fagorientert snarere enn en saksorientert forpliktelse. Med «fagorientering» forstår vi at forskningsinteressen avgrenses av etablerte forskningsspørsmål innenfor et fagområde, i mange tilfeller til det som betegnes som grunnforskning. Årvåkenhet for hva som kan skade forskningsprosessen - som økonomiske, sosiale eller politiske interesser - må ikke nødvendigvis implisere at pålitelig kunnskap kun kan produseres isolert fra ikke-vitenskapelige interesser.

Et fundamentalt problem med idealet om den interesseløse forskningen, uttrykt i generelle vendinger som en sannhetsforpliktelse, er nemlig at det raskt kan lede til en forståelse av at god forskning er forskning som ikke er rettet mot noe utover seg selv, sitt eget fag. Gjennom en slik fremstilling står vi i fare for å misforstå hva vi verdsetter i normen om interesseløshet. Sannhetsforpliktelsen synes nemlig å tre klarere frem desto mer de sekundære interessene forsvinner. Det betyr altså at jo mer 
unyttig forskningen fremstår, desto mer sann og ekte vil vi mene at den er. Et slikt ideal er historisk gjenkjennelig. Forskeren, sa rektor Otto Lous Mohr, «elsker vitenskapen mer enn seg selv [...]. Han patenterer ikke sine oppdagelser, utnytter dem ikke til økonomisk vinning. Han krever bare en rimelig godtgjørelse som sikrer ham anledning til konsentrasjon, den indre ro som er en nødvendig betingelse for hans forskning». Dette var talen rektor ved universitetet i Oslo holdt da han ønsket nye studenter velkommen til universitetet etter frigjøringen i 1945 (Hviid Nielsen, 2006: 53).

Det kan være grunn til å reflektere over spenningen i Mohrs utsagn. Den fremstår samtidig som gjenkjennelig og fremmed. Vår virkelighet, trekvart århundre etter Merton, er svært annerledes. Formaninger Merton refererer til som gjengs den gangen, er på langt nær like vanlige nå. De er snarere stikk i strid med dagens forskningspolitikk, som vektlegger samfunnsnytten. Rektor Mohrs tale fungerte trolig godt den gangen, men vi ville nok ha blitt overrasket om en rektor hadde sagt det samme i dag. Vi ville kanskje ha trukket litt på smilebåndet av dette gammelmodige språket og den naive idealismen. Et idealbilde av forskeren som stenger seg inne på kontoret sitt og trekker ned rullegardinene, treffer dårlig de anerkjente og karakteristiske trekkene ved dagens forskning.

Vi skal forfølge dette temaet videre ved å diskutere koblingen mellom idealet om interesseløshet og såkalt internalistisk vitenskapsteori som sto sentralt på 1980- og 1990-tallet.

\section{Interesseløshet og internalisme}

Merton blir ofte kritisert for å forsvare en internalistisk posisjon, en betegnelse som først og fremst er brukt i kunnskapssosiologien. Internalistiske posisjoner forutsetter at historien om vitenskapelige oppdagelser kan fortelles uten å forstå betydningen av, eller innflytelsen fra, samfunnet for øvrig. Dette er en forståelse av Merton som har festet seg. Én grunn til dette kan være at kritikken av Mertons internalisme inngår, som Steven Shapin (1992) påpeker, i standardfortellingen om historien til kunnskapssosiologien (og det bredere feltet som blir omtalt som STS-studier). Kritikken av internalistiske posisjoner var viktig, ettersom poenget 
med den var å åpne opp for sosiologiske, historiske og antropologiske studier av hvordan «vitenskapens innhold» ble formet.

Det er to grunner til at kritikken av internalistiske posisjoner er sentral for diskusjonen om interessekonflikt. I forlengelsen av hva vi har diskutert, er det en fare for at en internalistisk forståelse støtter et ideal om forskning for forskningens egen skyld - og blir seg selv nok understøttet av det vi kaller en fagorientert forpliktelse. Vi skal diskutere dette videre siden, men la oss først forfølge et annet spor. Det er nemlig også fare for at vi feilaktig diskrediterer normen om interesseløshet ved å se den som et uttrykk for en internalistisk posisjon. Vi trenger ikke ta stilling til om Merton er internalist eller ikke for å verdsette hans poengtering av nødvendigheten av å beskytte institusjonens primære interesser mot å bli kompromittert av sekundære interesser. Skillet er viktig å etablere, uavhengig av om spørsmålet om internalistiske posisjoner kan forsvares eller ei.

Det er viktig å få med seg en annen (eksternalistisk) side av Mertons argument. Villigheten til å akseptere institusjonell autonomi, argumenterer han i artikkelen «Normative structure of science», er avhengig av sosial aksept. Folk flest er ikke i stand til å vurdere vitenskapelige argumenter; en må være forsker for å kunne gjøre det. Dersom samfunnet skal bruke vesentlige ressurser på forskning, må den gi resultater som gjør investeringene meningsfulle også for ikke-forskere. Forskningen er til syvende og sist avhengig av demonstrasjon av samfunnsnytte, og den er sårbar for uønsket samfunnsutvikling. Det er nemlig en fare for at forskere blir for blendet av sin egen suksess og glemmer avhengighetsforholdet institusjonen har til samfunnet for øvrig. Forskningens selvstyre vil måtte begrunnes i - og være avhengig av - tillit til at forskningsaktiviteten i det store og hele understøtter utviklingen av et godt samfunn.

With the unending flow of achievements, [... the scientist came to regard himself as independent of society and to consider science as a self-validating enterprise which was in society but not of it. (Merton 1942: 551)

Det er nettopp en slik forståelse av forskningens uavhengighet til samfunnet som har blitt utfordret i kritikken av internalistiske posisjoner.

Denne kritikken uttrykkes blant annet av Sandra Harding, som en refleksjon over hvordan objektivitet blir knyttet til nøytralitet. Hun 
kritiserer et objektivitetsbegrep som fanger oss i et valg mellom objektivitet og relativisme.

Where the old "objectivity question" asked, "objektivity or relativism: which side are you on?", the new one refuses this choice, seeking instead to bypass widely recognised problems with the conceptual frameworks that restricts the choices to these two. (Harding, 1995: 331)

I den gamle objektivitetsdiskusjonen kobles objektivitet til nøytralitet på en bestemt måte. Jo mindre forskningen er påvirket av samfunnet, jo mer objektiv og nøytral er den. Denne gamle iscenesettelsen av objektivitetsdiskusjonen utspilte seg som en jakt på internalisiske redegjørelser for den vitenskapelige metode. Hardings anliggende - i likhet med andre samtidige, som Paul Feyerabend - er at et slikt vitenskapsteoretisk prosjekt samtidig legitimerer vitenskapens delaktighet i opprettholdelsen av eurosentrisme, mannsdominering og klasseforskjeller. Sann vitenskap kan ikke være delaktig i urett. En objektiv og nøytral vitenskap vil jo måtte være hevet over kjønns-, rase- og klassemotsetninger i kraft av å være interesseløs.

Dette objektivitetsidealet, som knytter interesseløshet til internalistiske posisjoner, gir ikke redskaper til å kritisere forskningens egne innebygde verdier samt betingelser og føringer for forskningen. Harding mener at svakhetene i det dominerende objektivitetsidealet kan avdekkes ved å ta utgangspunktet i de marginalisertes ståsted eller livsverden (1995: 342). Gjennom en anerkjennelse av sosial ulikhet vil hun demonstrere at internalistiske vitenskapsteoretiske posisjoner har et «svakt» objektivitetsideal. En bevissthet om at kunnskapsproduksjon alltid er situert, og dermed knyttet til bestemte historiske situasjoner, til politiske, materielle og kulturelle forutsetninger, og til etablerte maktforhold, vil derimot uttrykke et sterkt objektivitetsideal.

Hardings kritikk betyr imidlertid ikke at idealet om interesseløshet ikke er gyldig. Som vi nevnte innledningsvis, kan interessekonflikt oppstå i alle profesjoner ettersom det handler om vern av profesjonens primære formål - dens samfunnsoppgave. Det vi foreslår, er at idealet om interesseløshet uttrykker en saksorientert forpliktelse med et interesseløshetsideal som ikke knyttes til en internalistisk vitenskapsteori. Men 
før vi forfølger dette sporet videre, skal vi tydeliggjøre aktualiteten av problemstillingen ved kort å minne leseren på vitenskapsteoridiskusjonen som var sentral rundt årtusenskiftet.

\section{Mode 2 - nye koplinger mellom vitenskapelige, industrielle og politiske virksomheter}

«Mode 2» er en betegnelse på en form for kunnskapsproduksjon som skiller seg fra den typiske vitenskapen på Mertons tid. Den er kontekstdrevet, problemorientert og flervitenskapelig (Gibbons mfl., 1994), og kjennetegner blant annet storsatsinger innenfor forskning, for eksempel det som omtales som konvergerende teknologier (Nordmann, 2004). Den har et klart anvendt perspektiv, og rettferdiggjøres ofte i kraft av samfunnsnytte. Vel så viktig er det at den uttrykker et ideal om en kunnskapsproduksjon som er kontekstdrevet. Forskningen skal ikke utføres og bli formsatt innenfor de enkelte disipliner, men snarere i en anvendt kontekst. Det er betegnende at Ziman omtaler denne kontekstdrevne forskningen som «post-akademisk». De siste tiårene har «Mode 2» blitt en standardbetegnelse i policydokumenter både internasjonalt og i Norge, selv om analysen som ga opphav til begrepet, har vært gjenstand for mye kritikk. Et karakteristisk trekk ved Mode 2-forskningen er at forskere samarbeider mer på tvers av fag og samfunnssektorer (Gibbons mfl., 1994: vii), og et slikt samarbeid har langt på vei slått inn som en allmenn forventning til hva en god forsker bør etterstrebe. Interdisiplinært samarbeid og industrisamarbeid blir begge uttrykk for det grunnleggende trekket ved denne typen forskning - samarbeid i den hensikt å oppnå samfunnsnytte. Gibbons og hans kolleger forutså at Mode 2-tenkning, som de den gang anslo preget arbeidsmåten til kun $5 \%$ av alle forskere, ville få mer allment gjennomslag.

Vi er i starten av en overgangsfase, argumenterte Gibbons mfl. for, der det ikke er klart hvilke endringer vi bør ønske velkommen og hvilke vi bør motarbeide (1994: 1). I praksis utfordres forskere i en rekke nye situasjoner hvor slike vurderinger må gjøres, og der nettopp spørsmålet om hva som utgjør profesjonens primære og sekundære formål, blir sentralt. Spørsmål om vi bør samarbeide mer som enkeltforskere og som 
institusjoner, på tvers av fag og på tvers av samfunnssektorer, berører jo nettopp vår identitet som forskere - hva vi er her for.

I Mode 2-verdenen ser det ut til at forskerhverdagen har blitt reorganisert for stadig flere forskere, og det på måter som gjør at interesseløsheten blir satt på prøve. Industrisamarbeid er et eksempel på en type samarbeid som - sett fra utsiden - kan være krevende å forene med interesseløshet. La oss se nærmere på to eksempler for å klargjøre hva interesseløshetsidealet kan bety i slike samarbeid.

\section{Moser, Alzheimers og saksorienterte forpliktelser}

Det blir fort både abstrakt og komplisert når vi sier at forskernes profesjonsutøvelse ikke skal ha noe bestemt for øye. Forskerne skal være interesseløse, samtidig som vi i denne teksten har hevdet at idealet om interesseløshet ikke er uforenlig med at forskningen er samfunns- og nytteorientert. Vi forstår dette som at forskningen skal ha frihet til å være saksorientert. Det er saken som skal forplikte forskerne, samt standarder for god forskningspraksis. Forskningen skal være fri til å forfølge saken - for så å si å kunne gjøre det saken krever. «Saken» er her å forstå som forskningens gjenstand eller tema.

Når May-Britt og Edvard Moser har forsket på hjernens hukommelsesstruktur, har de hevdet at deres primærinteresse har ligget i å avdekke og gjøre rede for denne strukturen. «Det er grunnforskning vi bedriver», har vært en standardsetning i nær sagt alle intervjuer med forskerne fra begynnelsen av 2000-tallet (se f.eks. Weisser, 2005). Nobelpris-vinnerne har sånn sett levd opp til den klassiske forståelsen av interesseløshet hos forskere, forstått som en slags likegyldighet til eventuell samfunnsnytte. I den senere tid har imidlertid Alzheimers sykdom kommet stadig mer i fokus hos Moser og Moser. I 2017 foreslo Edvard Moser for norske politikere at de burde bevilge penger til et Alzheimer-senter i Norge, hvor Moser-gruppen skulle inngå (Meland, 2017). Professor Christian Döller fra Tyskland var da allerede blitt hentet til Trondheim «... for å knekke alzheimergåten», som en avis uttrykte det (Opheim, 2016). Om vi antar at det i Moser-gruppen faktisk 
har vært en dreining fra grunnforskning mot å løse Alzheimer-gåten, hvordan kan vi forstå utviklingen i lys av interesseløshetsidealet? Har Moser-forskningen gått fra å være interesseløs til å tenke samfunnsnytte? Representerte Moserne av 2005 vitenskapens idealer på en renere måte enn Moserne av 2017, fordi de var mer interesseløse tidligere? Eller var det stikk motsatt?

For leserne burde svarene på disse spørsmålene være enkle. Moserforskningen av 2005 var trolig verken mer eller mindre interesseløs enn Moser-forskningen av 2017. Selv om forskningsfokuset (saken) har forflyttet seg fra en grunnforskningsinteresse (stedssansens opprinnelse og gridcellenes struktur) til en anvendt interesse (Alzheimers sykdom), er idealnormen for utforskning av begge områder interesseløshet. Moserne av 2017 er like mye avhengig av at sekundærinteresser ikke påvirker interessen av å frembringe pålitelig og troverdig kunnskap, som det Moserne av 2005 var. Mens måten å forske på, og ikke minst samarbeide på, vil måtte endre seg vesentlig når man etter hvert har ambisjoner om å finne en kur mot Alzheimers, er idealnormen for arbeidet akkurat den samme som før: Mosernes primærinteresse må fremdeles ligge i å frembringe pålitelig kunnskap. Sett utenfra er forskningen deres mer nytteorientert enn før. Sett innenfra er den - nå som før - saksorientert. Det er bare saken som har endret seg.

Likevel kan det være nyttig å dvele litt med intuisjonen om at vendingen mot Alzheimers vil innebære at forskningen ikke lenger var drevet av en interesseløs interesse. Hvorfor stiller vi det spørsmålet? Et mulig svar er at saksorientering forveksles med fagorientering. Vi har knyttet «fagorientering» til det at forskningsinteressen rettes mot etablerte spørsmål innen et fagområde. Spørsmål om hvordan hukommelsen fungerer fremstår mer interesseløst fordi det lettere kan fremstilles som et akademisk faglig spørsmål. Om det handler om Alzheimers sykdom, vil forskningen kontekstualiseres annerledes - der aktører som pasientgrupper, farmasøytisk industri og helsedepartementet kan tenkes å få langt større påvirkningskraft. Vi kan også spørre om dette skiftet er et resultat av at forskerne i større grad reflekterer over at kunnskap alltid er kunnskap for noen, og at de dermed i større grad åpner for innsikten om forskningens situerthet, og hvilke verdier som er innebygget i forskningsspørsmålene. 
Dermed vil dreiningen mot Alzheimer-spørsmålene samtidig kunne åpne for andre forskningsspørsmål, og dermed andre svar, enn de som ble reist gjennom det grunnlagsorienterte spørsmålet om hukommelsens struktur.

\section{Interessekonflikter i industrisamarbeid}

Offentlig forskning i Norge har selvsagt en lang tradisjon for tett industrisamarbeid. I nyere tid er dette særlig preget av at Norge er en oljenasjon, og at det hadde vært vanskelig å utvikle norsk oljeindustri uten tett samarbeid mellom blant andre NTH (nå NTNU) og oljeindustrien. Oljeselskapene har et betydelig samarbeid med de offentlige forskningsmiljøene, og bidrar også til finansieringen av en rekke forskningsprosjekter.

Industrisamarbeid begrenser seg imidlertid ikke til olje eller andre klassiske industriområder. Samarbeid på tvers av sektorer er ønsket i alle deler av forskningen i dag, også i den som tradisjonelt sett har ansett industrisamarbeid som etisk betent. Medisinsk forskning er et slikt eksempel. Derfra vet vi at interessekonflikter har vært et viktig tema i nyere tid, der kritikken har vært sterk mot det noen oppfatter som et samrøre mellom leger og legemiddelindustrien (Rørtveit, 2008: 553). Interessekonflikter kan eksempelvis oppstå når legens råd til pasienten ikke er «interesseløse», men farget av økonomiske bindinger til legemiddelindustrien. Her vil en orientering mot sak fremfor fag, med bevissthet om at man alltid er formet av bestemte interesser, gi redskap for å håndtere de kommersielle påvirkningene bedre, i tråd med Hardings kritikk av det ureflekterte nøytralitetsidealet. Til tross for historien med interessekonflikter på dette området er det like fullt ønsket og villet politikk i dag at offentlig forskning skal samarbeide mer og tettere med legemiddelindustrien. Én grunn til dette er at industrien har kapital som er nødvendig for å finansiere denne typen forskning, en annen grunn er at farmasøytisk industri har kompetanse i utvikling av medikamenter, en kompetanse forskere ofte mangler. I tillegg ønsker politikere at offentlig finansiert forskning i større grad skal lede til industri som gir arbeidsplasser og inntekter.

Et konkret eksempel på slikt samarbeid finner vi på biobankområdet. Forskningsrådet har brukt flere hundre millioner kroner de siste tiårene 
til å finansiere utbygging av norske biobanker for forskning på humant biologisk materiale. Byggingen av en slik infrastruktur må rettferdiggjøres. Det er ikke nok at man får god og spennende forskning i seg selv - i form av publikasjoner i anerkjente internasjonale tidsskrifter. Forskningen må lede frem til noe samfunnet har nytte av. Politikerne nøyer seg ikke med publikasjoner - de vil ha innovasjoner. Det er en legitim interesse for politikere. Derfor har man fra høyeste politiske hold signalisert at man ønsker industrisamarbeid i biobankforskningen. En av antagelsene er at en bare kan sikre at samfunnet får nytte av biobankforskningen gjennom et tett samarbeid med de store legemiddelselskapene. I 2016 bestemte Stortinget at det skulle etableres et nasjonalt kommersialiseringsselskap for biobank- og registerdata (Stortingsvedtak, 2016). Gitt at antagelsene er riktige, vil denne saken stille krav til et nært samspill mellom forskning, industri og politiske myndigheter.

Et annet eksempel er forskning på biodiesel basert på restprodukter fra norsk trevirke, som også i stor grad er basert på offentlige midler med krav om industrisamarbeid. Selv om både forskere og industri kan være skeptisk til at biodiesel vil være en del av løsningen på fremtidens energibehov, vil de kunne rettferdiggjøre sin deltagelse i forskningen med et slikt antatt samfunnsnyttig formål. De vil da være orientert mot saken, i dette tilfellet produksjon av biodiesel. Kunnskapsoppbyggingen deres vil da også ta hensyn til de samfunnsmessige, økonomiske og materielle forutsetningene for å lykkes med utvikling av en økonomisk og miljømessig bærekraftig produksjon av biodiesel. Dersom dette overordnede målet ikke nås, vil forskningen uansett ikke være bortkastet. Den har nemlig bidratt til ny kunnskap som er verdifull i seg selv, men som også kan lede til annen samfunnsnyttig produksjon som ikke er forutsett av de som finansierer forskningen.

Umiddelbart ser det krevende ut å ivareta interesseløsheten i slike typer samarbeid, der nytteverdien dominerer. Forskere som er ansatt ved offentlige forskningsinstitusjoner eller universiteter, må forholde seg til politikere som først og fremst er opptatt av samfunnsnytten, og til industrielle samarbeidspartnere som nødvendigvis har økonomisk tjenlige produkter og patenter som hovedinteresse. Utfordrende kan det også være for humanister, samfunnsvitere og jurister som må bidra 
med utforming av politikk og kjøreregler som ikke primært kritiserer, men snarere fasiliterer kommersialisering av offentlige forskningsressurser. Riktignok vil nettopp det siste innfri kravet til humanister og samfunnsvitere om at de skal vise samfunnsrelevans. Men mange samfunnsforskere mener at de er forpliktet på den kritiske rollen, og at det vil derfor være galt å gå inn i samarbeid som kan lede til at man må legge bånd på seg. Dette vil kunne oppleves som en interessekonflikt. Her synes også distinksjonen mellom fag- og saksorientering å kunne være opplysende. Paradoksalt nok, vil vi si, blir det å samarbeide - og dermed hjelpe til med å løse konkrete utfordringer - ofte opplevd som utfordrende for ens profesjonelle integritet, mens det å kritisere, analysere og vurdere mer på avstand, ikke blir det. En humanist eller samfunnsviter som deltar i anvendte prosjekter, vil ofte oppleve det som konfliktfylt dersom Alzheimers, biobankbruk eller biodieselutvikling presenteres som saken de skal være orientert mot.

Uansett har forskningen beveget seg inn i et område hvor forskerne vil måtte inngå i samarbeidsformer hvor interessene er mangfoldige. Samfunnsnytte og økonomisk nytte trer tydeligere frem, og forskerne blir mer vare for potensielle interessekonflikter. Eller som Ziman har formulert det: «With ever-increasing dependence on commercial or state funding, all modes of knowledge production are merging into a new, 'post-academic' research culture which is dominated by utilitarian goals. Growing concern about conflicts of interest is thus a symptom of a deep-seated malaise in science and medicine» (Ziman, 2002: 397).

Et sentralt spørsmål er om vi skal forstå de gjenkjennelige utfordringene ved moderne vitenskap generelt - og kanskje medisin spesielt - som «sykdomstrekk». Det er ikke umiddelbart lett å se hva implikasjonene av en slik diagnose vil være. Dersom vi ikke forstår det som uttrykk for et utidsmessig ideal om «forskning for forskningens skyld», i betydningen å være blindet for alle nyttehensyn, kan vi forstå diagnosen som uttrykk for en profesjonell bekymring, et ubehag forskerne ikke helt vet å diagnostisere - gitt konfliktfylte forskningspolitiske Mode 2-trender.

Derfor er det verdt å merke seg premissene for samarbeid i Mode 2-forskningen: Offentlig forskning driver ikke industrisamarbeid for å tjene penger. Når nye ph.d.-studenter blir innført i en verden av patenter 
og TTO (Technology Transfer Offices), skyldes ikke det at de skal lære å berike seg. Snarere skyldes det at de skal lære seg å ivareta samfunnsinteresser, og dermed virkeliggjøre det som betegnes som universitetenes tredje oppdrag - samfunnsengasjement (Etzkowitz \& Leydesdorff, 200o) - der de to første er utdanning og forskning. Samfunnsinteresser er ikke nødvendigvis å forstå som interesser som står i motsetning til interesseløshetsidealet i forskning, men snarere som en supplerende del av den akademiske virksomheten. De samfunnsinteressene som forskningen i Norge skal tjene, handler om vår interesse i å trygge vår velferd, om å fremme demokrati, om å sikre menneskerettigheter og om å utvikle en mer rettferdig verden. Dersom samarbeid er nødvendig for å lykkes med dette, så synes samarbeid - av alle typer - å være en god ting. Industrisamarbeid på universitetene rettferdiggjøres altså ut fra tanken om at et slikt samarbeid er nødvendig for å realisere de godene vi mener forskningen skal og bør forsøke å realisere.

I et slikt perspektiv fremstår det ikke så radikalt at man i Mode 2 har tanker om hvordan vitenskapen kan og bør tjene samfunnet. Snarere er det idealet om forskeren som jobber isolert på sitt kontor med rullegardinen nede, upåvirket av alle utenforstående interesser, som fremstår som problematisk. For også et slikt ideal vil kunne tjene politiske interesser, og da er det bedre å sette ord på hvordan forskningsinteresser og samfunnsinteresser bør sameksistere for å skape gode samfunnsløsninger, enn å sikre integriteten av arbeidet innenfor de enkelte sfærene. For som vi har diskutert: Det å sikre forskingens integritet gjennom vern som hjelper forskningen med å være saksorientert, hviler på en implisitt forutsetning om at forskningen på denne måten kan bidra til et bedre samfunn. Det handler med andre ord om ikke å ta for gitt at en saksorientert forpliktelse er en innadvendt fagorientert forpliktelse. Det er heller ikke slik at en forpliktelse på en saksorientert forskning som ivaretar samfunnets kunnskapsbehov, svekker forskningens kritiske rolle. Forskere må ha en kritisk inngang til etablerte forståelser og antagelser for å bidra til en kunnskapsbasert samfunnsutvikling.

Vi vil peke på to forhold i oppsummeringen av hva som står på spill når det gjelder interessekonflikter i dagens forskningsvirkelighet. Det handler om å unngå samrøre - uten samtidig å blokkere produktivt 
samarbeid. Begge knyttes til det gjensidige avhengighetsforholdet mellom forskning og samfunnet for øvrig, som blant andre Merton vektla.

\section{Interesseløshet og forskning for et godt samfunn}

I Mode 1-forskningen kunne idealet synes å være at forskningen er til for sin egen skyld. Desto mer innadvendt forskningen var, desto tydeligere fremsto forskeren som uegennyttig og interesseløs. Faren er at interesseløshetsidealet forbindes med en internalistisk vitenskapsteoretisk posisjon som vil legitimere en motvilje mot å inngå i de samarbeidsrelasjoner saken krever. Dersom en forsker bidrar med sin kompetanse og forskning på en måte som tjener andres interesserer, kan det oppleves som om hun svikter sin egen profesjonelle oppgave. Et fruktbart samarbeid kan dermed vanskeliggjøres av idealer om interesseløshet. I slike tilfeller kan det være fristende for en forsker å unngå samarbeidet under dekke av å skulle beskytte sin egen profesjonelle integritet. Denne forståelsen lever i beste velgående i universitetsmiljøer, men er etter vår mening et uheldig utslag av en bekymring for å bli styrt av illegitime sekundærinteresser.

I Mode 2-forskningen står også den samfunnsmessige rettferdiggjøringen sentralt. Forskning har, ideelt sett, det gode samfunn som formål. Forskeren kan ikke og får ikke være interesseløs med tanke på denne anvendelsen av forskningen. Alle former for samarbeid som er nødvendig for å realisere dette godet, skal tas i bruk. I et slikt perspektiv vil interesseløshetsidealet fremstå som naivt og innsiktsløst. Men også dette har en bakside. Det vil kunne gi næring til kulturer som aksepterer et ureflektert samrøre av interesser. Idealet om interesseløshet må ikke kastes ut med badevannet - med innsikten om at forskningsinteresser og samfunnsinteresser samproduseres. Det vil si at vitenskap og samfunn står i et gjensidig påvirknings- og avhengighetsforhold som umuliggjør ideen om en isolert vitenskapelig kunnskapsopparbeidelse.

Den forståelsen av interesseløshet som vi mener er verdt å forsvare, er en saksorientert forståelse. Men denne er ikke nødvendigvis sammenfallende med en fagorientert forståelse. Der en fagorientert interesseløshet kan forstås dit hen at forskerne må få frihet til å forske på det fagområdet de anser som et viktig forskningsfelt, vil en saksorientert forståelse 
vektlegge friheten forskerne har til å forfølge et saksområde som kan inkludere harmonisering til aktiviteter utført av aktører utenfor deres eget fagfelt. Å være saksorientert vil ikke alltid bety at en er fagorient, selv om kvalitetsstandarder for forskere er knyttet til rådende standarder innenfor egen fagdisiplin. Hvorvidt man faktisk forfølger saken selv, avgjøres ikke av forskeren selv, og heller ikke av hennes samarbeidspartnere eller oppdragsgivere. Det er forskningsinstitusjonens systemer for kvalitetssikring som foretar vurderingen. I institusjonell forstand er forskningen interesseløs dersom den tilfredsstiller det aktuelle fagfellesskapets selvregulerende vurderingssystemer. Disse inntrer primært ved publisering av resultatene, og derfor kan man si at en akademikers faglige aktivitet ikke er forskning før resultatene er presentert for kolleger i fagfellevurderte tidsskrifter eller bøker. Da er det irrelevant om interesser sekundært til de primære forskningsinteressene også er involvert, det være seg i form av samfunnsnyttige funn eller patenterbare oppdagelser. Riktignok finnes det mange måter å undergrave denne kvalitetssikringen i fagfellesystemet på. Her kan nevnes kameraderi i vurderingen eller opprettelse av spesialtidsskrift som styres av sekundærinteresser, for eksempel industrihensyn eller politiske gruppeinteresser. Men muligheten for slike brudd på god praksis betyr ikke at det er praksisen det er noe feil med, og i det lange løp vil slike brudd på prinsippet om saksorientering bli avslørt.

Det er heller ikke gitt at kvalitetsmessig god og saksorientert forskning sammenfaller med at noe er moralsk og politisk godt. Et forskningsprosjekt kan representere god forskning ved å være interesseløst, samtidig som det er samfunnsmessig skadelig - for eksempel hvis det stigmatiserer utsatte grupper. Likedan kan forskningen gi gode samfunnsmessige resultater i form av nye behandlinger - selv om forskeren av egeninteresse har tatt snarveier for å komme først til patentet, og dermed brutt med de institusjonelle kriteriene for interesseløshet.

I det siste tilfellet er det ikke saken selv som har vært den avgjørende motivasjonsfaktoren, men derimot den økonomiske egeninteressen. Den sviktende saksorienteringen vil for eksempel kunne avsløres i kvaliteten på spørsmålsstilling, valg av metode, analyser og andre faktorer som vurderes av fagfellesskapet. Og det er den institusjonelle etterprøvingen som viser at dette ikke har vært saksorientert, men at sekundærinteresser har 
vært drivende for aktiviteten. Slik er det en direkte sammenheng mellom den institusjonelle tilnærmingen til forskningens interesseløshet og kravet om saksorientering.

Men vi må like fullt spørre oss om hvordan forskere virkelig kan vite at de har vært drevet av å forfølge saken dit den bringer dem? Når kan de være trygge på at de har vært tro mot saken, at den rette ekspertisen har blitt konsultert og har fått deltatt i vurderingen? Vurderingen av om en forsker har vært saksorientert, må foretas av andre interessenter som har kjennskap til saken, og som ikke nødvendigvis tilhører forskerens eget fagmiljø. Enkelte prosjekter - som f.eks. biobanker - kan være så krevende at saken stiller omfattende krav til koordinert deltagelse fra ulike fagdisipliner, næringsliv og borgere, ettersom store nasjonale og internasjonale forskningsinfrastrukturer vil måtte finansieres, bygges og vedlikeholdes. Hvilke krav saken stiller, og hvor fleksible disse kravene er, inngår som del av det som må avklares og vurderes i forskningsprosessen.

\section{Konklusjon}

Idealet om interesseløshet er koblet til epistemiske dyder som pålitelighet, saklighet og troverdighet. Identifikasjon av interessekonflikter går ut på verne om denne forskningsprosessen og sikre at forskningen er fri til å være saksorientert. Dette handler om hvilke situasjoner vi ikke skal gå inn i, om forbudssoner som trekkes opp forut for forskningsprosessen. Spørsmålet engasjerer fordi det aktualiserer forskernes identitet, og vil utløse motstand når det er mistanke om at deres integritet er truet. Internaliserte forståelser av hvilke situasjoner forskere skal gå inn i eller ikke, er en viktig del av sunn selvregulering. Forskere skal være årvåkne for interessekonflikter der det kan være fare for at de svikter sitt mandat, og dermed seg selv, ved ikke å være rettet mot saken, og forskningen skal samtidig være fri til å innrette seg etter saken. Men nettopp fordi identifisering av interessekonflikter innebærer forbudssoner, kan et for snevert forsvar av forskning for forskningens egen skyld true dens mulighet til å oppfylle sitt samfunnsoppdrag. Her befinner dagens forskere seg ofte i et krevende farvann. Grensesetting mellom forsknings- og samfunnsinteresser inngår noen ganger i et nødvendig vern av forskningens rolle som 
kunnskapsleverandør. Men i tilfeller der saken krever et produktivt samspill med andre samfunnsaktører, kan grensesetting hindre forskningens rolle som kunnskapsleverandør. Det som står på spill i spørsmål om interessekonflikter, er forskningens frihet til å innrette seg etter saken, som ikke ureflektert må forstås som en fagorientert forpliktelse eller en frihet til å ignorere samfunnsinteresser.

\section{Referanser}

Djørup, S., \& Kappel, K. (2013). The norm of disinterestedness in science; a restorative analysis. SATS - Northern European Journal of Philosophy, 14 (2), s. 153-175.

Etzkowitz, H., \& Leydesdorff, L. (2000). The dynamics of innovation: From National Systems and "Mode 2" to a Triple Helix of university-industry-government relations. Research policy, 29, s. 109-123.

Hacking, I. (1983). Representing and Intervening. Cambridge: Cambridge University Press.

Harari, Y.N. (2016). Sapiens. En kort historie om menneskeheten. Oslo: Bazar forlag.

Harding, S. (1995). «Strong objectivity»: A response to the new objectivity question. Synthese, 104 (3), s. 331-349.

Hviid Nielsen, T. (2006). Fristere og syndere i det universitets-industrielle kompleks - apropos tilfældene Hwang og Schön. I R. Nydal \& B. Solberg (Red.), Juks, uredelighed og god forskning. Trondheim: Tapir forlag.

Kaiser, M. (2015). Forskningens verdier. I Forskningsetisk bibliotek. Hentet 25. januar 2018 fra: https://www.etikkom.no/FBIB/Introduksjon/Systematiske-oghistoriske-perspektiver/Forskningens-verdier/

Kant, I. (1987). Critique of Judgment. Trans. Indianapolis: Hackett Publishing.

Knorr-Cetina, K. (1999). Epistemic cultures: How the sciences make knowledge. Cambridge: MIT Press.

Meland, S.I. (2017). Vil ha Alzheimersenter nå. Adresseavisen 22. mars 2017.

Merton, R.K. (1938). Science and the social order. Gjenopptrykt i R.K. Merton (1973), The sociology of science: Theoretical and empirical investigations. Chicago: University of Chicago Press.

Merton, R.K. (1942). The normative structure of science. Gjenopptrykt i R.K. Merton (1973), The sociology of science: Theoretical and empirical investigations. Chicago: University of Chicago Press.

Nordmann, A. (Rapporteur) (2004). Converging technologies - Shaping the future of European societies. European Commission, Brussels. Hentet 25. januar 2018 fra: http://scholar.google.no/scholar_url?url=http://pure.iiasa.ac.at/1259o/1/ Converging\%2520Technologies.pdf\&hl=en\&sa=X\&scisig=AAGBfmol 
TuzJ4WRMqKDlEZr6v3rHCFE59g\&nossl=1\&oi=scholarr\&ved= oahUKEwjkkc6F_PPYAhVFFywKHXmyA7cQgAMIKCgAMAA

Opheim, A. (2016). Til Trondheim for å knekke alzheimergåten. Adresseavisen 22. juni 2016.

Pickering, A. (1992) (red.). Science as practice and culture. Chicago: Chicago University Press.

Shapin, S. (1992). Discipline and bounding. The history and sociology of science as seen through the externalism-internalism debate. History of Science, 30, s. $333-369$.

Stortingsvedtak (2016). Representantforslag om et løft for norske biobanker. Dokument 8: 24 S (2015-2016), Innst. 250 S (2015-2016). Hentet 25. januar 2018 fra: https://www.stortinget.no/no/Saker-og-publikasjoner/Saker/Sak/?p=6418o

Thompson, D.F. (1993). Understanding financial conflicts of interest. New England Journal of Medicine, 329, s. 573-576.

Tobin, M.J. (2003). Conflicts of interest and AJRCCM. Editorial. American journal of respiratory and critical care medicine, 167, s. 1161-1166.

Tranøy, K.E. (1986). Vitenskapen - samfunnsmakt og livsform. Oslo: Universitetsforlaget.

Weisser, A. (2005). NTNU-forskere fant stedsansen. Adresseavisen, 19. juni 2005.

Ziman, J. (1996). Is science losing its objectivity? Nature, 382, s. 751-752.

Ziman, J. (2002). The continuing need for disinterested research. Science and Engineering Ethics, 8, s. 397-399. 



\title{
KAPITTEL 2
}

\section{Forskerens frihet når interesser vil styre}

Stig S. Gezelius

Universitetet i Sørøst-Norge

Klaus Mittenzwei

Norsk institutt for bioøkonomi

\begin{abstract}
Actors who seek to restrict scientists' academic freedom often believe they have legitimate reasons for doing so, and this belief often relies on misunderstandings regarding the nature and rationale of freedom in science. This chapter explains principles of freedom in science, why these principles matter, and how they can be protected when interests conflict. The authors distinguish between four freedoms in science: freedom of subject, freedom of source, freedom of interpretation, and freedom of speech. These freedoms each serve their scientific purpose and are - each to their own degree - important to the legitimacy of science. The authors argue that the freedoms of interpretation and speech, especially, must be absolute in science. This chapter delves particularly into the freedom of speech, because interested parties frequently attack this freedom when they fight over knowledge presented to the public. The authors draw on their experiences from the Norwegian scientific community to exemplify how problems of academic freedom may arise and eventually be solved.
\end{abstract}

Keywords: science, ethics, academic freedom, freedom of speech, conflicts of interest, research institutes

\section{Styringsbehov versus frihet i forskning}

Interessekonflikter i forskning uttrykkes sterkest gjennom forsøk på å hindre forskere i å følge sin faglige overbevisning. Både arbeidsgivers, oppdragsgivers og andre forskeres interesser kan motivere slike forsøk. I

Sitering av dette kapitlet: Gezelius, S. S., \& Mittenzwei, K. (2019). Forskerens frihet når interesser vil styre. I H. Ingierd, I. Bay-Larsen \& K. Hiis Hauge (Red.), Interessekonflikter i forskning (s. 45-68). Oslo: Cappelen Damm Akademisk. https://doi.org/10.23865/noasp.63.ch2

Lisens: CC BY 4.0 
en tid der vitenskapelig virksomhet gjennomorganiseres og behovsstyres, kommer forskerens frihet under press.

Aktører som innskrenker forskerens frihet, påberoper seg ofte retten til å innskrenke. I noen tilfeller har de gode grunner til dette, men ofte ledsages innskrenkninger av misforståelser omkring forskningsfrihetens natur og begrunnelse. Formålet med dette kapitlet er å bidra til klarhet om hva forskningsfrihet er, hvilke funksjoner denne friheten har, og hvordan friheten kan beskyttes når interesserte parter kjemper om allmenhetens virkelighetsoppfatning. Ettersom ytringsfriheten er særlig sårbar i slike konflikter, vier vi den spesiell oppmerksomhet.

Forskningsfriheten omfattes av den mer generelle «akademiske friheten». Akademisk frihet forstås som frihet til å søke og formidle kunnskap uten styring gjennom ytre maktbruk. Akademisk frihet innebærer, i det aller minste, frihet til ikke å måtte handle i strid med egen faglig overbevisning (NOU 2006: 10). UNESCO (1997) slår fast at den akademiske friheten betinges både av akademiske institusjoners faglige autonomi og av fagansattes rett til å produsere og formidle kunnskap i tråd med personlig faglig overbevisning. For fagansatte omfatter denne friheten typisk valg av forsknings- eller studiefelt, forskningsmetoder, undervisningsvirksomhet og formidling (Kallerud, 2006; UNESCO, 1997).

Forskerens plikt til sannferdig kunnskapssøken, og til sannferdig kunnskapsformidling, fordrer rett til å følge egen faglig overbevisning (Tranøy, 1995: 53-56). Det er forholdet mellom denne plikten og denne retten som begrunner den akademiske friheten (AAUP, 2017; UNESCO, 1997).

Idealet om akademisk frihet strekker seg tilbake til opplysningstida (Kallerud, 2006), og plikten til å trygge denne friheten er i dag nedfelt i en av FNs menneskerettighetskonvensjoner (1966) og i norsk lov (Regjeringen, 2005, 2008). Tanken om akademisk frihet har tradisjonelt vært sterkest knyttet til forsknings- og undervisningsinstitusjoner (AAUP, 2017; Kallerud, 2006). De senere tiåras fremvekst av rene forskningsinstitutter, som også er forpliktet av vitenskapens krav, har imidlertid utvidet diskusjonen om akademisk frihet og ført til en delvis institusjonalisering av denne friheten også for rene forskningsinstitutter (Regjeringen, 2008; Stortinget, 2010). 
Institusjonalisering av den akademiske friheten har ikke fritatt den for press. Moderne vitenskap er så ressurskrevende at den krever god organisering. Organisering krever styring, og styring begrenser de ansattes frihet. Dertil kommer samfunnets krav om brukerrelevans: Forskningsfinansiering betinges ofte av resultatenes forventede nytte. Styringsbehov splitter samfunnets tilnærming til forskningsfrihet. På den ene siden hersker tilsynelatende konsensus om frihetsidealet, men på den andre siden uthules idealet gjennom måten vitenskapen organiseres på (NOU, 2006).

\section{De fire forskningsfrihetene og deres formål}

Idealet om forskningsfrihet omfatter flere aspekter ved forskeres virksomhet. Vår analyse skiller mellom fire underkategorier av forskningsfrihet. Vi kan kalle disse for temafrihet, kildefrihet, tolkningsfrihet og ytringsfrihet. Disse fire frihetene angår hvert sitt stadium i forskningsprosessen, fyller ulike funksjoner, og er i ulik grad fravikelige.

Forskningsfrihetene tjener to krav til god vitenskap: kravene om at kunnskapen skal være mest mulig sann og mest mulig ny. Selv i fag der de fleste har gitt opp troen på at det er mulig å finne en ugjendrivelig sannhet, lever forpliktelsen til å etterstrebe, så langt mulig, sannhetsidealet. Kravet til sannferdighet er derfor absolutt (Tranøy, 1986: 20-21). Sannferdighetskravet er vitenskapens viktigste etiske norm.

Vitenskapen er dermed underlagt et sannhetsideal og et nyhetsideal. Sannhetsidealet er definitorisk nødvendig: Søker man ikke sannhet, bedriver man ikke vitenskap. Nyhetsidealet angår først og fremst forskningens kvalitet. Søker man ikke ny kunnskap, bedriver man uinteressant vitenskap.

I det følgende beskriver vi de fire forskningsfrihetenes innhold, samt hvordan frihetene, hver på sin måte, tjener sannhetsidealet og nyhetsidealet. Vi drøfter hvordan frihetene støter mot interesser i samfunns- og organisasjonsliv, og vi drøfter hvordan viktige utfordringer kan håndteres.

\section{Temafrihet versus krav om relevans}

Den første av de fire forskningsfrihetene betegner vi som temafrihet. Temafrihet betyr at forskere autonomt velger hvilke problemstillinger de 
skal forske på. Temafrihet tjener nyhetsidealet fordi forskerne oftest selv best vet hvor kunnskapshullene på deres felt finnes. Temafrihet gir også forskere mulighet til å følge egen motivasjon samt jobbe med samme tema over tid, slik at de opparbeider kompetanse til å flytte kunnskapsfronten. Forarbeidene til universitets- og høyskoleloven fremhever at hensynet til vitenskapelig originalitet begrunner personlig akademisk frihet (NOU 2006: 17, 54).

Temafrihet fremmer altså vitenskapens utvikling, men er ikke nødvendig for å bedrive vitenskap. Forskere kan søke sannhet, etter vitenskapelige prinsipper, også når andre bestemmer temaene for dem. Riktignok vil forskningens nyhetsverdi - og dermed kvalitet - kunne synke, men sannhetsidealet kan tilfredsstilles like godt som ellers.

Graden av temafrihet er gjerne en avveining mellom vitenskapens nyhetsideal og samfunnets nyttekrav. Forskning finansieres oftest av aktører utenfor vitenskapen - offentlige myndigheter eller private organisasjoner -, og disse aktørene er sjelden tilfredse med kun å bringe vitenskapen fremover. De forventer at forskningen skal være nyttig for dem (se f.eks. NOU 2006: 19). Offentlige forskningsmidler, bevilget gjennom nasjonale forskningsråd, er derfor i stor grad programstyrte. Det vil si at forskningsmidler bevilges til temaer myndighetene, gjerne i samråd med interesseorganisasjoner og forskningsmiljøer, fastsetter. Fordi forskningsprogrammene er tidsavgrensede, og ofte formes av skiftende samfunnsbehov, fremmer de ikke alltid langsiktig kompetansebygging. I Norge sikres temafrihet først og fremst gjennom statens tematisk åpne utlysninger og grunnbevilgninger. I instituttsektoren kan grunnbevilgninger likevel være underlagt tematiske prioriteringer fra departementene.

Spesielt forskningsinstituttene mottar betydelige forskningsmidler gjennom oppdrag fra private eller offentlige aktører. Oppdragsforskning er behovsstyrt og gir sjelden rom for store vitenskapelige nyvinninger.

I oppdragsforskning inngås kontrakter mellom oppdragsgiver og forskerens arbeidsgiver. Kontraktsforpliktelsene utformes oftest i nært samarbeid med forskerne som skal utføre oppdraget. Likevel skjer det at forskere må avbryte pågående prosjektarbeid. Da sitter arbeidsgiver igjen med kontraktsforpliktelsen. Følgelig vil arbeidsgivere kunne ha behov for å instruere forskere til å produsere kunnskap om det temaet kontrakten spesifiserer. Tilsvarende vil man i universitets- og høyskolesektoren 
finne forskere som tilsettes på prosjektbasis (NOU 2006: 45). Slik bruk av arbeidsgivers styringsrett begrenser temafriheten, men forskerne kan fortsatt utøve vitenskap så lenge de tre resterende friheter - kildefrihet, tolkningsfrihet og ytringsfrihet - respekteres.

\section{Kildefrihet versus krav om interessebeskyttelse}

Når forskere har valgt - eller fått tildelt - sitt tema, søker de data om dette temaet. Kildefriheten skal trygge forskernes tilgang til disse dataene. Vitenskapens sannhetsideal fordrer datatilgang. Vitenskap kan derfor ikke eksistere uten kildefrihet. Kildefrihet betyr at forskere autonomt velger hvor og hvordan de henter sine data. Det vil si at de selv velger forskningsmetoder, samt hvor og overfor hvem metodene benyttes. Fordi forskningens resultater avhenger av metodevalg, må forskere ha frihet til å bruke de metoder de mener gir det riktigste bildet av virkeligheten: Kildefrihet fremmer oppfyllelse av vitenskapens sannhetsideal.

Til tross for sin grunnleggende betydning har kildefriheten flere aksepterte begrensninger. Forskningsprosjekter begrenses av tidsfrister og økonomiske rammer. Bare sjelden har forskere mulighet til å hente alle dataene de ønsker seg. Dertil kan kravet om kildefrihet kollidere med etiske krav om å ta hensyn til forskningsobjektene (NENT, 2016; NESH, 2016; NOU 2006: 20-21). Disse etiske og ressursmessige begrensningene betyr at ikke alt og alle kan gjøres til gjenstand for vitenskap. Vitenskapens virksomhetsområde begrenses til de feltene der tilgangen til legitime kilder er stor nok til at sannhetsidealet i akseptabel grad kan oppfylles.

Innskrenkninger i kildefriheten blir etisk problematisk når de skyldes strategisk motivert maktbruk: Oppdragsgivere, for eksempel, kan ønske å offentliggjøre kun informasjon som fremstiller dem i et gunstig lys, eller som bekrefter deres versjon av virkeligheten. Slike innskrenkninger i kildefriheten strider mot det Merton (1968: 612-614) kaller vitenskapens krav om desinteresse - kravet om at utenomvitenskapelige interesser ikke skal overstyre vitenskapens plikt til sannhetssøken (se Nydal mfl. i denne boka). Når vitenskapens desinteresse blir trukket i tvil, skjer det samme med sannferdigheten. 
Prinsippet om kildefrihet tilsier at flest mulig i forskerkollektivet har tilgang til data, fordi datatilgang fremmer etterprøvbarhet og nyskaping. Den som frembringer data, kan ha et legitimt behov for eksklusiv bruksrett i prosjektperioden. Dertil kan personvernhensyn og avtaler med informanter gi legitime grunner til begrensninger også etter prosjektperiodens utløp. Med mindre forskningsetiske hensyn tilsier noe annet, bør eksklusive bruksrettigheter unngås etter prosjektslutt. Forskningsinstitusjoner bør ikke akseptere at oppdragsgivere gis langvarig eksklusiv bruksrett til data frembrakt som del av oppdraget, spesielt ikke når oppdragsgiver skal bruke resultatene offentlig. Like fullt finnes det økonomiske insentiver til å akseptere oppdragsgiveres krav om bruksrett (se eksempel A).

\section{Eksempel A: Kildefrihet i oppdragsforskningen}

Oppdragsforskning er en av få muligheter offentlige institutter har til å bygge egenkapital og et av kriteriene for utmåling av den resultatbaserte grunnbevilgningen. Norsk institutt for bioøkonomi (NIBIO) produserer mange rapporter finansiert av private oppdragsgivere. Ofte ønsker oppdragsgivere eksklusiv bruksrett til resultatene, enten fordi de ønsker kontroll med publisering, eller fordi rapporten inneholder bedriftssensitive data. NIBIO aksepterer tidsavgrenset eksklusiv bruksrett, men produserer i enkelttilfeller også rapporter der den eksklusive bruksretten er permanent. Sistnevnte praksis er omdiskutert i NIBIO, spesielt når oppdragsgivere bruker rapportene til å påvirke offentlig politikk og forvaltning.

I vår drøfting av temafriheten nevnte vi at arbeidsgivere av kontraktsmessige hensyn kan måtte instruere ansatte til å jobbe på prosjekter der forskningsmetodene er spesifisert. Prinsippet om kildefrihet fordrer at arbeidsgiver i slike tilfeller instruerer kun forskere som går god for metodene (se Giertsen, 2006).

\section{Tolkningsfrihet versus krav om «rett» tro}

Når forskere har generert sine data, skal de tolke dataene for å avgjøre hva dataene forteller dem. For å kunne tolke dataene trenger forskere 
begreper og teorier. Tolkningsfrihet betyr at forskere autonomt utvikler og velger teorier og begreper, samt måten disse belyser (eller belyses av) data på. Kort sagt innebærer tolkningsfrihet at forskere autonomt velger sin virkelighetsforståelse; at makt ikke brukes for å forhindre bestemte måter å tenke på. Tolkningsfriheten sikrer tenkningens frihet i vitenskap. Når tenkningens frihet begrenses, sløves den vitenskapelige bevisstheten. Tolkningsfrihet er derfor en ufravikelig forutsetning for vitenskap.

Tolkningsfriheten fremmer både nyhetsidealet og sannhetsidealet i vitenskap. Nyhetsidealet fordi tolkningsfrihet tillater brudd med etablerte tankemønstre. Sannhetsidealet fordi tolkningsfrihet tillater sannferdighet og kritikk. Tolkningsfriheten beskytter altså det Merton (1968: 614-615) kaller vitenskapens organiserte skeptisisme. Likeledes beskytter tolkningsfriheten prinsippet om at vitenskapelige synspunkter motiveres kun av saklig grunngiving (Tranøy, 1986: 64-66).

Historisk sett har ytre maktbruk, i form av politisk eller religiøst motiverte forsøk på å disiplinere folks tenkning, begrenset forskeres tolkningsfrihet. Men også innenfor forskningsinstitusjoner kan maktbruk redusere tolkningsfriheten, spesielt i faglige konflikter. Konflikter som bunner i legitim faglig uenighet, kan perverteres gjennom forskernes forsvar av personlig renommé, karrieremuligheter og finansiering. Kollegiale sanksjoner - slik som latterliggjøring, stempling eller ubegrunnet ignorering - kan fortrenge saklig grunngiving. I vitenskap er saklig grunngiving det eneste legitime virkemidlet for å påvirke andres tenkning. Tolkningsfriheten er derfor ufravikelig.

\section{Ytringsfrihet versus krav om styrt formidling}

Når forskere har tolket sine data, skal de formidle sin kunnskap til allmennheten. Interessekonflikter merkes ofte best i denne fasen, når allmennhetens virkelighetsoppfatning og de involverte partenes renommé settes på spill. Ønsket om å påvirke hva allmennheten får høre, kan være sterkt, også blant arbeids- og oppdragsgivere som har makt over forskerne. Forskernes ytringsfrihet er derfor særlig utsatt. 
Ytringsfriheten omfattes av den mer generelle akademiske formidlingsfriheten, som i tillegg til ytringsfrihet omfatter institusjonens - og delvis den enkelte lærers - rett til å utforme de regler formidlingen avhenger av, slik som obligatoriske pensa og undervisningsopplegg. I forskningssammenheng står imidlertid den rene ytringsfriheten mest sentralt.

Ytringsfriheten er tolkningsfrihetens tvilling blant de akademiske frihetene. Mens tolkningsfrihet betyr at forskere autonomt kan velge sin virkelighetsforståelse, betyr ytringsfrihet at forskere autonomt kan kommunisere sin virkelighetsforståelse til andre. Vi skal se nærmere på ytringsfrihetens innhold og begrunnelse, samt to institusjoner som påvirker ytringsfriheten: det personlige forfatterskapet og opphavsretten.

\section{Ytringsfrihetens innhold og begrunnelse}

En vanlig misforståelse er at ytringsfrihet begrunnes med en norm om toleranse. Begrunner man ytringsfrihet med toleranse, vil man mene at ytringsfrihetens grenser bør settes ved grensene for vår toleranse. Denne misforståelsen kan skade vitenskapen på to måter. For det første kan misforståelsen føre til maktbruk, eller til krav om maktbruk, for å forhindre utolererbare ytringer. En slik maktbruk kan være at ytringer må godkjennes av ledelsen eller en oppnevnt «kvalitetsansvarlig» før de tillates fremmet offentlig. På den annen side kan misforståelsen føre til at offentlig kritikk oppfattes som angrep på ytringsfriheten, hvilket undergraver forskningens kritiserbarhet.

Ytringsfrihet har ingenting med toleranse å gjøre. Ytringsfrihet har å gjøre med måten man tilkjennegir sin intoleranse på. For eksempel, kritikk av andres ytringer er ikke angrep på ytringsfriheten: Kritikk er legitim bruk av ytringsfriheten. Det er et anerkjent prinsipp at akademisk frihet favner frihet til kritikk (NOU 2006: 14). Moralisering gjennom utsagn som «det burde du ikke sagt offentlig», er heller ikke angrep på ytringsfriheten. Først når man bruker makt, truer med maktbruk eller oppfordrer til maktbruk, for å styre eller hindre andres ytringer, snakker vi om angrep på ytringsfriheten. Karakteristisk for maktbruk, slik vi her definerer begrepet, er disiplinerende virkemidler annet enn ytringer rettet mot ytringer. 
Typisk for maktbruk er at den rettes mot ytreren fremfor ytringen. To vanlige former for maktbruk er handlinger som 1) berøver andre muligheten til å ytre seg, eller 2) har til hensikt å true eller skade personer som ytrer seg. Skaden kan - blant mye annet - være av karrieremessig, økonomisk og sosial art.

I tråd med ytringsfrihetskommisjonens forståelse (NOU 1999: 3) kan vi karakterisere ytringsfrihet som en tvangsfri offentlig samtale, en offentlig samtale der ytringer som ikke selv målbærer tvang, er eneste legitime middel til å regulere andres ytringer (Gezelius, 2010).

Når det gjelder bruk av rettslige maktmidler, innebærer ytringsfrihet at borgere skal kunne ytre seg uten risiko for å stilles rettslig ansvarlige, i form av straff- eller erstatningsansvar, for ytringen (Giertsen, 2006b; Stortinget, 2004).

Man kan spørre seg hvorfor vitenskapen avhenger av ytringsfrihet. Ville ikke vitenskapen styrkes om man forbød offentliggjøring av dårlig forskning? Vi skal nå se på hvorfor svaret på dette spørsmålet er «nei».

Vitenskapens nyhetsideal fordrer mulighet til offentlig å bestride etablert kunnskap. Ytringer som bestrider etablert kunnskap, har, per definisjon, flertallet imot seg. Flertallet vil legge etablert kunnskap til grunn når de vurderer kvaliteten på nyskapende forskeres arbeider. Derfor må nyskapende forskere, før de blir tatt på alvor, ofte argumentere bedre enn forskere som støtter seg på etablert kunnskap. Nyskapende forskere kan oppleve å bli stemplet som inkompetente, sågar useriøse, i starten. Den etablerte kunnskapens dominans som kvalitetsstandard har følgende konsekvens: Når forskeres ytringer siles gjennom maktbruk, uansett hvor velment den måtte være på vitenskapens vegne, slutter vitenskapen å bevege seg fremover. Maktpersoner vil kunne stoppe nyskapende ytringer i den tro at de sikrer kvalitet.

Enda viktigere er ytringsfrihetens betydning for sannhetsidealet. Skal man søke sannhet, må man være sannferdig, altså snakke i tråd med egen overbevisning. Snakker man mot bedre vitende, søker man ikke sannhet, og da bedriver man ikke vitenskap. Enhver som ytrer seg etter instruks fra andre, risikerer å ytre seg mot egen overbevisning. Derfor er ytringsfrihet en absolutt forutsetning for sannferdighet (NOU, 2006; Gezelius, 2012). 
Ytringsfrihetskommisjonen fremhevet opplysningstidas vitenskapelige rasjonalitetsideal som grunnlag for ytringsfriheten. Kommisjonen fremholdt dermed demokrati, fri meningsdannelse og fremfor alt sannhetss $\varnothing$ ken som de sentrale verdier ytringsfriheten skulle beskytte (NOU, 1999).

Ikke bare skal forskere opptre sannferdig, de skal også dele sin kunnskap med andre: Forskere har formidlingsplikt (NOU 2006: 46; UNESCO, 1997). Formidlingsplikten er, i samsvar med UNESCOs (1997) retningslinjer for akademisk frihet, nedfelt i de etiske retningslinjer for statstjenesten (Regjeringen, 2012).

I likhet med sannferdighetsplikten fremmer formidlingsplikten sannhetsidealet: Skal forskere finne sannheten, må de kunne vurdere alle argumenter, og da må argumentene være offentlig tilgjengelige (NOU 1999: 19; Gezelius, 2012). Offentlighetsprinsippet er derfor grunnleggende i vitenskapen. Offentlighetsprinsippet beskytter både forskningens kritiserbarhet (NOU 2006: 46) og prinsippet om at vitenskapelig kunnskap skal være tilgjengelig for alle (se Merton, 1968: 610-612).

Ytringsfrihetskommisjonen uttrykte ytringsfrihetens grunntanke presist: Bare fri, kritisk, offentlig samtale kan bringe menneskets feilbarlige fornuft i retning av dypere innsikt; jo mer feil et menneske tar, jo viktigere er det at feilen kan underkastes offentlig kritikk (NOU 1999: 19).

Vitenskap er institusjonalisering av fornuft. Uten fri, offentlig samtale bryter den kollektive fornuften sammen. Å sile ytringer gjennom maktbruk er antivitenskapelig.

\section{Ytringsfrihetens konsekvenser for organisert vitenskap}

Vi har sett at vitenskapens sannferdighetskrav begrunner ytringsfriheten. En viktig, og ofte oversett, implikasjon av sannferdighetskravet er at forskere ikke kan ytre seg på andres - ei heller sine arbeidsgiveres - vegne. Grunnen er at sannferdighet fordrer autonomi, og autonomi er uforenlig med representasjon: Skal forskere være tro mot plikten til å ytre sin overbevisning, kan de ikke ytre seg etter instruksjon. Kan de ikke ytre seg etter instruksjon, kan de heller ikke ytre seg i kraft av å representere noen (Gezelius, 2010, 2012). 
Forskere kan ha et legitimt behov for å informere om yrke og arbeidssted når de ytrer seg om faglige spørsmål. Noen mener derfor at frittalende forskere kan komme i lojalitetskonflikt overfor arbeidsgiver. Forestillingen om lojalitetskonflikt forsvinner imidlertid når man innser at organisasjoner ikke kan ha vitenskapelige meninger. Fordi forskningsinstitusjoner ikke er selvstendig tenkende bevisstheter, kan de aldri ta standpunkt etter vitenskapelige prinsipper: Gyldigheten av vitenskapelige argumenter avgjøres ikke gjennom organisatoriske prosedyrer slik som avstemninger eller lederbeslutninger. Sannhet vedtas ikke.

Oppfatningen om at organisasjoner bør ta stilling i vitenskapelige spørsmål, bygger altså på en sviktende forståelse av beslutningsgrunnlaget i vitenskap. Organisasjoner kan simpelthen ikke hevde faglige meninger og samtidig påberope seg vitenskapelighet. Vitenskapelige organisasjoner må være faglig nøytrale. I faglig nøytrale organisasjoner vil forskere som ytrer sin faglige overbevisning, aldri komme i lojalitetskonflikt overfor arbeidsgiver (Gezelius mfl., 2010: 3-5).

\section{Eksempel B: Institutters faglige nøytralitet}

Forskningsinstituttenes kultur og formidlingsrutiner inneholder som oftest ikke noe prinsipp om faglig nøytralitet. NIBIOs formidlingspolicy sier følgende om formidling:

«Den som kvalitetssikrer går god for forskernes resultater på vegne av NIBIO. Ved usikkerhet eller tvil, det vere seg om faglige eller formelle spørsmål, skal saken forelegges Forskningsdirektøren.»

NIBIOs forskere skal altså ytre seg på arbeidsgivers vegne, og organisasjonens instruksjonslinjer skal brukes til beslutninger om faglig innhold. NIBIOs rapporter publiseres med en leders signatur i rubrikken «Godkjent». NIBIO får regelmessig forespørsler om å avgi høringsuttalelser i faglige spørsmål, hvilket innebærer at offentlige myndigheter etterspør instituttets faglige mening. NIBIO har ingen formell rutine for å sikre organisasjonens faglige nøytralitet i forbindelse med høringsuttalelser. 
Det syn at forskere ytrer seg på sine arbeidsgiveres vegne, hevdes også av utvalget som i 2018 (på oppdrag fra Norges forskningsråd) evaluerte primærnæringsinstituttene. Utvalget skriver (Brekk mfl., 2018: 32-33):

«[I]nstituttene bør ha gode systemer for kvalitetssikring av rådgivningen. Det inneborer systemer som gjør at enkeltforskeren ikke stilles til ansvar alene, men at det er instituttet som står bak de rådene som gis. [...] På dette området hviler det også et særlig ansvar på myndighetene, som må respektere forskningsfagligheten samt verdien og nødvendigheten av uavhengig rådgivning.

I sin omtale av NIBIO utdyper utvalget (Brekk mfl., 2018: 65):

«Det må sikres at det er instituttet som gir råd til noringsliv og forvaltning, ikke den enkelte forsker.»

Prinsippet om organisasjonens faglige nøytralitet er institusjonalisert på universitetene, men i instituttsektoren søker oppdragsgivere kunnskap som legitimeres av institusjonen. Oppdragsgivere ønsker ikke at rapporten de har kjøpt, skal kritiseres av forskere ved institusjonen der rapporten ble skrevet (se Andersen i denne boka). Forskere i instituttsektoren forventes derfor å ytre seg på sine arbeidsgiveres vegne (se Eksempel B). Når oppdragsforskeren ytrer seg kontroversielt, blir arbeidsgiveren avkrevd svar. Arbeidsgiveren presses således mot styrt formidling.

Ytringsfriheten innskrenkes når arbeidsgivere definerer det å støtte kollegaers forskning - eller i det minste ikke å kritisere den offentlig som en del av lojalitetsplikten. Denne lojalitetsforståelsen motiverer krav om at forskernes ytringer må godkjennes av ledelsen før de kan offentliggjøres. Slik maktbruk er forståelig i lys av omgivelsenes forventninger, men er forskningsetisk uakseptabel. Forestillingen om at forskere, så snart de oppgir yrke og arbeidssted, ytrer seg på arbeidsgivers vegne, er blant de alvorligste truslene mot forskernes ytringsfrihet.

Også faglig nøytrale institusjoner vil måtte ta offentlig standpunkt i spørsmål knyttet til regulering av institusjonens livsvilkår (for eksempel lovgivning angående institusjonens virksomhet). I slike spørsmål vil institusjonen måtte tillate egne ansatte å ytre seg mot egen arbeidsgiver, fordi slike spørsmål ofte angår faget. Likeledes må forskere, dersom ytringsfriheten skal være reell, langt på vei være suverene i sin vurdering 
av hva som angår faget. Strid om ytringers berettigelse bør i så måte føres gjennom en maktfri diskusjon.

I instituttsektoren er det ikke uvanlig at ledere rutinemessig krever å få forskeres planlagte offentlige utspill til gjennomsyn. Spesielt når det gjelder medieutspill, er slike rutiner vanlige. Arbeidsgivere betegner ofte slike rutiner som «kvalitetssikring». Lederes krav om gjennomsyn bryter ikke nødvendigvis med ytringsfriheten hvis lederen kun inntar en rådgivende rolle. Likevel innebærer kravet en uheldig sammenblanding av lederrollen og rådgiverrollen. Råd som er gitt av en leder, vil ofte oppleves bindende, og ledere besitter maktmidler som ansatte vanskelig kan overse. Følgelig bør kollegiale fagfelleordninger, istedenfor organisasjonens instruksjonslinjer, brukes til å kvalitetssikre medieutspill og andre offentlige ytringer. Prinsippet om institusjoners faglige nøytralitet innebærer at både ytringsretten og ansvaret for ytringen blir værende hos forfatteren - også etter at kvalitetssikringen er gjennomført.

Kollegiale fagfelleordninger er ikke til hinder for at ansatte orienterer sine ledere om planlagte offentlige utspill, noe god skikk ofte tilsier at ansatte gjør. Krav om at ledelsen orienteres, begrenser ikke ytringsfriheten.

\section{Ytringsfrihet og forfatteransvar}

Ulikt de fleste andre yrkesgrupper har forskere personlig forfatterskap til arbeider produsert i yrkessammenheng. Det personlige forfatterskapet følger av forskernes rett til selv å bestemme hva de ytrer, og er en logisk konsekvens av at forskere ytrer seg på egne, ikke arbeidsgivers, vegne. Personlig forfatterskap er altså blant ytringsfrihetens forutsetninger.

Med frihet følger ansvar. Det personlige forfatterskapet innebærer at forskere selv står faglig og rettslig ansvarlige for sine ytringer. Risiko for å stilles rettslig til ansvar for ytringer vil hindre den frie offentlighet som sannhetssøken avhenger av. Derfor har Norge et grunnlovsfestet fritak fra rettsansvar for de aller fleste typer ytringer (NOU, 1999; Stortinget, 2004). De særskilte ytringstypene som utløser rettsansvar - for eksempel hatefulle, kriminalitetsoppfordrende eller visse typer ærekrenkende ytringer (Regjeringen, 1969, 2005b) - er ikke forbundet med vitenskap. 
For faglitterære forfattere som følger vanlige forskningsetiske normer, vil ansvaret være av rent faglig art: Forfattere risikerer offentlig kritikk og kanskje svekket faglig omdømme, men ikke rettslige sanksjoner, når de ytrer sin faglige overbevisning. Forskningsinstitusjoner kan derfor ikke begrunne begrensninger i forskeres ytringsfrihet ut fra risikoen for å stilles rettslig til ansvar.

Arbeidsgivere bør ikke holdes ansvarlige for noe de ikke har myndighet over (NOU 2006: 23). Prinsippet om arbeidsgivers faglige nøytralitet tydeliggjør forfatterens eneansvar for det faglige innholdet. Forfatteren, ikke vedkommendes arbeidsgiver, må stå til rette for faglig kritikk. Forfatteren står faglig ansvarlig også når ytringen fremsettes i arbeidsgiverens publikasjonsserier: At redaktør og utgiver finner ytringen publiseringsverdig, betyr ikke at de stiller seg bak den.

Forskningsetikkloven slår fast at forskningsinstitusjoner har et etisk ansvar, men ansvaret må være, slik proposisjonen sier, å skape gode institusjonelle rammebetingelser for etisk forsvarlig forskning, for eksempel gjennom opplæring av egne forskere (Regjeringen, 2016: 20-21; Regjeringen, 2017). Institusjonens ansvar kan ikke utøves gjennom overstyring av forskernes faglige overbevisning.

Forskere i instituttsektoren er særlig utsatt for forventningen om å ytre seg på arbeidsgivers vegne. Det er fordi instituttene utgir mye forskning i egne publikasjonsserier, og fordi massemedier fremstiller forskeres synspunkter som institusjonens (se Eksempel C). Slike forventninger skaper usikkerhet omkring ansvarsforholdene. Når arbeidsgiver opplever seg ansvarlig for sine forskeres ytringer, er veien til styrt formidling kort.

\section{Eksempel C: Massemedier forveksler personlig med institusjonelt}

\section{forfatterskap}

Massemediene skaper ofte et inntrykk av at institusjonen er forfatter. For eksempel, i Dagsavisen 12.03.16 under overskriften «Tallkluss i skattekommisjon» skriver journalisten «NIBIOs konklusjoner ...» og «... skriver NIBIO», selv om rapporten er skrevet av én ansatt ved instituttet. I Nationens leder 13.02.17 står det: «Nibio har sikkert regnet både samvittighetsfullt og godt ...» Og i en artikkel fra ABC Nyheter o8.11.16 står det: «Det betyr at NIBIO gir inntrykk av at det ...» 
Når forskningsinstitusjoner utgir egne publikasjonsserier, er forholdet mellom arbeidsgiverrollen og redaktørrollen viktig. Redaktøren kan, i sin publiseringskanal, stille betingelser for publisering og refusere publiseringsforslag. Forutsatt et mangfold av publiseringskanaler, er ikke redaktørfunksjonen noen stor trussel mot ytringsfriheten (NOU 1999): Arbeidsgivere bør aldri hindre forskere i å publisere i eksterne kanaler. Problemet er at forskere ofte ikke når frem i publiseringskanaler utenom arbeidsgivers publikasjonsserier, hvilket betyr at redaktørmakten kan begrense ytringsfriheten betydelig. Redaktørmakt må i forskningsorganisasjoner derfor utøves aktsomt.

Aktsom utøvelse av redaktørmakt fordrer at redaktørrollen skilles tydelig fra arbeidsgiverrollen. Grunnen er at arbeidsgiver kan ha sterke interesser angående forholdet til eiere og kunder, og samtidig utstrakt makt over ansatte. Rolleblanding skaper derfor uklarhet om både interessefrihet og ytringsfrihet. I stedet for å blande arbeidsgiverrollen og redaktørrollen, som forskningsinstitutter gjerne gjør (se Eksempel D), bør redaktøren gis selvstendig myndighet og ikke ha lederansvar overfor forskerne. Likeledes bør redaktørens beslutninger bygge på kollegiale vurderingsordninger, slik som den tradisjonelle fagfelleordningen, istedenfor beslutninger i linjeorganisasjonen.

\section{Eksempel D: Uklare skiller mellom redaktørrollen og arbeidsgiverrollen}

I en utredning om "Akademisk frihet i NIBIO-kontekst», som er utarbeidet av en intern arbeidsgruppe og godkjent i NIBIOs ledermøte for videre behandling i avdelingene, står følgende om redaktøransvar: "Arbeidsgruppa anbefaler at fagredaktøransvaret for NIBIOs utgivelser plasseres i linjeorganisasjonen for å sikre best mulig faglig innsikt og minst mulig administrative flaskehalser [...] Avvisning av et manuskript kan ankes oppover i linjeorganisasjonen, dvs. til fagredaktørens leder».

Uklare ansvarsforhold skaper uklare roller. Noen institutter tilslører forfatteransvaret i egne publikasjonsserier gjennom vagt definerte roller, som «faglig ansvarlig» eller «kvalitetsansvarlig» (se Eksempel B). Slike 
«ansvarlige» står ikke selv som forfattere, men presenteres likevel som ansvarlige for ytringen. Fordi ansvar impliserer myndighet, sår slike roller tvil om ytringsfriheten. I stedet for å oppgi «faglige ansvarlige» i sine rapportserier, kan arbeidsgiver oppgi rapportseriens redaktør og eventuelt også de fagfellene som har bistått redaktør og forfatter med faglige råd.

\section{Ytringsfrihet og opphavsrett}

Opphavsretten har et tvetydig forhold til ytringsfrihet. Åndsverkloven sikrer ytreren rett til publisering av egne arbeider, enerett til endring av egne arbeider samt rett til å nekte offentliggjøring av eget arbeid (Regjeringen, 1961).

Forfatterens rett til publisering er en betingelse for ytringsfrihet. Forfatterens rett til å nekte publisering står imidlertid i et tvetydig forhold til ytringsfriheten. På den ene siden omfatter ytringsfriheten rett til taushet (NOU 1999: 330), og denne retten sikrer at forskere kan forbli tro mot egen overbevisning når de mener deres egne arbeider ikke holder mål. På den annen side kan opphavsretten innskrenke ytringsfriheten ved at forfatterne nekter utgivere å offentliggjøre verk allmenheten har behov for (NOU 1999: 181).

Problemet med opphavsrettens begrensende virkning bør, av to grunner, ikke overdrives. For det første begrenser opphavsretten kun muligheten til å offentliggjøre forfatterens fremstilling av kunnskapen, ikke kunnskapen som sådan (NOU 1999: 182). Andre står fortsatt fritt til å offentliggjøre sin egen fremstilling av kunnskapen, forutsatt at de følger god krediteringsskikk. For det andre finnes det så sterke insentiver for publisering, og så sterke disinsentiver for taushet i moderne forskning, at forskere sjelden motsetter seg publisering.

At åndsverkloven som hovedregel gir forskeren, og ikke arbeidsgiveren, opphavsrett til forskerens arbeider (Torvund, 2010), innebærer at forskeren selv avgjør hvordan og hvorvidt arbeidet skal offentliggjøres. Arbeidsgivere iverksetter formidlingsplikten gjennom generelle formidlingskrav, ikke gjennom krav til at bestemte ytringer skal formidles på bestemte måter (NOU 2006: 46).

Likevel skjer det at arbeidsgivere, spesielt i instituttsektoren, kontraktfester sin plikt til å publisere prosjektresultater på bestemte måter. 
Derfor kan arbeidsgivere ha legitim interesse av å kreve opphavsrett til forskernes arbeider. Overdragelse av opphavsrett til arbeidsgiver vil samtidig kunne begrense ytringsfriheten fordi arbeidsgivere kan bruke sin opphavsrett til å begrense publiseringen, for eksempel etter krav fra oppdragsgivere.

Gjeldende rettspraksis tilbyr, etter vårt skjønn, ansatser til løsning på konflikten mellom ytringsfrihet og arbeidsgivers interesser. Åndsverklovens hovedregel er at opphavsretten tilhører forfatteren, mens rettspraksis samtidig tilsier at:

[O]pphavsrett til verk skapt i ansettelsesforhold, i mangel av annen avtale, vil kunne anses overgått til arbeidsgiveren $i$ den utstrekning det er nødvendig for at ansettelsesforholdet skal nå sitt formål og det dessuten er omfattet av arbeidstakerens oppgaver i arbeidsforholdet å skape slike verk. (Regjeringen, 1992: 21, vår utheving)

Forskernes opphavsrett til egne arbeider harmonerer med rettspraksis, nettopp fordi forskernes opphavsrett fremmer ansettelsesforholdets formål. Det grunnleggende formålet i vitenskapelige ansettelsesforhold er samvittighetsfullt å skape og formidle kunnskap i tråd med egen faglig overbevisning. Rettspraksis bør ikke tolkes på en måte som innskrenker forskernes mulighet til å oppfylle dette formålet. Følgelig må opphavsretten sikre forskere rett til både ytring og taushet. Derfor må opphavsretten, som grunnleggende prinsipp, ligge hos forfatteren.

Kun i tilfeller der arbeidsgiver er kontraktsforpliktet til å utgi bestemte ytringer på bestemte måter, og forfatterne motsetter seg slik utgivelse, kan rett til offentliggjøring rimeligvis overdras til arbeidsgiver. Likevel vil prinsipper for sannferdighet og ytringsfrihet i slike situasjoner pålegge arbeidsgiver å gi forfatterne mulighet til i det minste ikke å ytre seg mot egen faglig overbevisning (se NOU 2006: 10, 16; Tranøy, 1995: 53-56). Forfatteren bør, for eksempel, kunne ta de forbehold vedkommende mener er nødvendig. Forfatteren må også stå fritt til å formidle sin kunnskap, i ny utforming, andre steder enn i de kanaler oppdragskontrakten spesifiserer. Denne tolkningen av regelverket vil kunne trygge arbeidsgivers interesser innenfor en rimelig ramme av ytringsfrihet (se eksempel E). 


\section{Eksempel E: Uklarhet om forskeres opphavsrett}

Etter henvendelse fra Norsk institutt for landbruksøkonomisk forskning (NILF), avga Landbruks- og matdepartementet (LMD) i 2010 en uttalelse angående forskeres opphavsrett til egne arbeider. LMD støttet seg på Justis- og politidepartementet som, uten nærmere presisering eller begrunnelse, uttalte at «forskningsresultata i mange tilfelle måtte reknast for å vere gått over til arbeidsgjevaren» (Regjeringen, 2010). LMD syntes dernest å legge til grunn at arbeidsgiver hadde opphavsretten med mindre opphavsretten var overdratt til forskeren gjennom særskilt avtale (Regjeringen, 2010b). Spørsmålet om forskernes opphavsrett ble lagt på is etter møte mellom LMD, NILFs ledelse og NILFs fagforeninger. Saken illustrerer behovet for å tolke opphavsretten grundig i lys av vitenskapens særpreg.

Kravet om troskap mot egen faglig overbevisning, fordrer at retten til å endre verket blir værende hos forfatteren. Om retten til endring av verk skulle overdras arbeidsgiver eller oppdragsgiver, ville vitenskapelige grunnprinsipper settes til side. Torvund (2010: 39) påpeker at overdragelse av opphavsrett normalt ikke omfatter rett til å endre verket; slik rett må avtales spesielt. Vitenskapelige normer tilsier at slike avtaler bør unngås. I tilfeller der slike avtaler likevel kan være legitime, som ved nyutgivelse av verk med mange forfattere (Torvund, 2010: 39), bør man sikre forfatternes mulighet til å reservere seg mot endringer. I tilfeller der redaktørens kvalitetskrav eller institusjonens kontraktsforpliktelser tilsier at forfatterens arbeid revideres før utgivelse, bør revisjonene gjøres, eller i det minste godkjennes, av forfatteren.

Overdragelse av opphavsrett til oppdragsgiver følger lignende prinsipper som overdragelse av opphavsrett til arbeidsgiver (Torvund, 2017). Forskningsinstitusjoner bør i størst mulig grad unngå kontrakter som overfører opphavsrett til oppdragsgivere, både fordi forskningsinstitusjoner ikke har hjemmel til å overføre opphavsrettigheter som ligger hos den enkelte forfatter (se Torvund, 2017: 7), og fordi erverv av slik hjemmel - for eksempel gjennom ansettelseskontrakter - vil kunne stride mot vitenskapelige normer for ytringsfrihet og formidlingsplikt. 


\section{Forskernes frihet versus deres lojalitetsplikt}

Ansattes lojalitetsplikt overfor arbeidsgiver er nedfelt i norsk rettspraksis og tilsier at arbeidstakere skal sette arbeidsgiverens interesser fremst. Forskere plikter dertil å være lojale mot egen faglig overbevisning - de har en overordnet lojalitetsplikt mot vitenskapen (Kallerud, 2006: 9-10). I dette avsnittet drøfter vi forholdet mellom disse to lojalitetskravene.

Lojalitetsplikten begrenser arbeidstakernes frihet $\mathrm{i}$ arbeidsforholdet. Likevel sikrer den lovfestede ytringsfriheten allmenn rett, også for arbeidstakere, til å delta i saklig samfunnsdebatt, selv om slik debatt skulle innebære kritikk mot egen arbeidsgiver. Det skal mye til før en ytring rettslig sett kan betraktes som illojal (NOU 1999: 1706; Stortinget, 2004: 36-9). Både Underdal-utvalget og de etiske retningslinjene for statstjenesten fremhever vitenskapelig ansattes særlige ansvar for å bidra til kritisk samfunnsdebatt (NOU 2006: 37; Regjeringen, 2012: 9).

I vitenskapelige organisasjoner vil forskeres lojalitetsplikt overfor arbeidsgiver ikke bare tillate, men kreve lojalitet mot egen faglig overbevisning. Dette fordi lojalitet mot egen faglig overbevisning er institusjonalisert i vitenskapelige organisasjoners formål: Arbeidsgivers viktigste interesse er å bevare organisasjonens vitenskapelige karakter, hvilket innebærer at forskerne stimuleres til å oppfylle sin sannferdighetsplikt og sin formidlingsplikt. Det hersker derfor et grunnleggende lojalitetssamsvar mellom hensynet til arbeidsgiver og hensynet til faglig overbevisning i vitenskapelige ansettelsesforhold.

Temafriheten utgjør ifølge vår argumentasjon et delvis unntak fra lojalitetssamsvaret. Arbeidsgiver kan ha en legitim interesse av å legge tematiske føringer. Likeledes er forskernes kildefrihet underlagt forskningsetiske begrensninger som arbeidsgiver legitimt kan iverksette. Innenfor disse begrensningene står forskningens frihet ikke i noe motsetningsforhold til lojalitetsplikten.

Arbeidsgiveres kortsiktige interesser kan komme i konflikt med de langsiktige. Metodevalg og tolkninger kan være kontroversielle, og sannferdige ytringer kan være upopulære. Likevel vil slike kontroverser være å foretrekke fremfor den tvilen om vitenskapelighet som formidlingsstyring skaper. 
Arbeidsgivers faglige nøytralitet fremmer lojalitetssamsvaret: Når arbeidsgiver ikke fremmer faglige syn, kan forskerne fremme sine uten å komme i konflikt med arbeidsgiver. Spesielt for institutter i oppdragsmarkedet kan poenget være vanskelig å akseptere. Imidlertid vil organisasjoner som ikke hevder faglig nøy tralitet, risikere å komme i situasjoner der de pådrar seg rykte som vitenskapelig tvilsomme.

Medieoppmerksomhet rundt forsøk på formidlingsstyring har utløst krav om styrking av forskningsfriheten i instituttsektoren (se Eksempel F). Kunnskapsdepartementet føyde derfor i 2013 et prinsipp om akademisk frihet til sine retningslinjer for statlig basisfinansiering av forskningsinstitutter. I tilføyelsen står det:

Instituttet må legge til rette for at prinsippene om akademisk frihet skal gjelde for all offentlig finansiert forskning som utføres av forskere ansatt ved instituttet, $\underline{\text { så }}$ fremt det ikke kommer $i$ konflikt med arbeidsgivers styringsrett. Forskerne skal ha [...] størst mulig frihet til å uttale seg offentlig om sin forskning, frihet til a fremme nye ideer og frihet til à velge metode og materiale for sitt forsknings- og utviklingsarbeid innenfor de rammer som følger av ansettelsesforholdet, prosjekt-

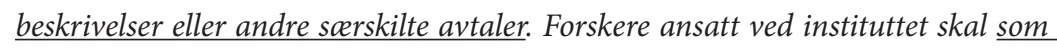
hovedregel ha rett til å offentliggjøre sine resultater [...]. (Regjeringen $2008 \$ 4$, våre uthevinger)

Departementet anerkjente betydningen av akademisk frihet i instituttsektoren, men tok samtidig så grunnleggende og uklare forbehold (se våre uthevninger) at tiltaket synes å ha begrenset verdi. Akademisk frihet innebærer per definisjon begrensning av arbeidsgivers styringsrett, men departementets retningslinjer er i beste fall uklare om hvordan, og i hvilken utstrekning, akademisk frihet begrenser styringsretten.

\section{Eksempel F: Maktbruk og frihetskrav i instituttsektoren}

I 2009 publiserte en forsker ved Norsk institutt for landbruksøkonomisk forskning (NILF) en krass aviskronikk mot landbrukspolitikken. En daværende ekspedisjonssjef i Landbruks- og matdepartementet (NILFs eier og største oppdragsgiver) sendte da e-post til NILFs direktør med en skarp oppfordring om å skrive et avisinnlegg om at NILF 
ikke støttet innholdet i kronikken. Ekspedisjonssjefen forsvarte sin e-post ved å uttale i et intervju at han «oppfatter [at] universitetsprofessorer [har] en friere rolle enn instituttene» (Nationen, 2009a, b). Etter protester fra NILF-forskere og stortingspolitikere bekreftet landbruksministeren NILFs faglige uavhengighet. Saken førte til at Stortinget ba regjeringen fremme forslag som tydeliggjorde den akademiske friheten i instituttsektoren (Brekk, 2009; Gezelius mfl., 2009; Nationen, 2009c; Stortinget, 2010).

Forskere jobber ofte i prosjektgrupper, tidvis i store konsortier. Kontrakter skal oppfylles. Budsjetter, myndighet og ansvar skal fordeles. Likevel fordrer vitenskapelige prinsipper at rent faglige beslutninger fattes gjennom kollegiale prosesser: Medforfatterskap fordrer konsensus om innhold og må følgelig være frivillig. Prosjektdeltakere må kunne publisere alternative, kritiske synspunkter og endre sin posisjon over tid. Prosjektgruppeorganisering begrenser temafriheten. Deltakerne står ikke fritt til å følge ethvert innfall de måtte få, men tolknings- og ytringsfriheten må gjelde fullt ut.

\section{Konklusjon}

Prinsippet om akademisk frihet fordrer at vitenskapelige organisasjoner tuftes på respekt for den enkeltes faglige samvittighet. Akademisk frihet krever aktsomhet på toppen og ryggrad i bunn. Forskningsinstitusjoner kan ikke forvente at kunder og eiere uten videre skal forstå grunnlaget for forskernes frihet. Vitenskapens institusjoner vinner forståelse og aksept gjennom å oppdra sine omgivelser. Når institusjoner gir etter for omgivelsenes forventninger om styring av forskerne, svekkes de vitenskapelige frihetsnormene.

Skal institusjonene lykkes med å oppdra sine omgivelser, bør de realisere og forsvare sin faglige nøytralitet, ikke minst overfor massemediene. På dette feltet har instituttsektoren kommet betydelig kortere enn universitetssektoren. Instituttsektorens faglige legitimitet avhenger av sektorens vilje til å ta fatt på oppgaven. Offentlige myndigheter kan stimulere 
denne viljen ved å tydeliggjøre sitt hittil uklare krav om akademisk frihet for forskere i instituttsektoren.

\section{Takk}

Takk til Jens B. Grøgaard, redaktøren og to eksterne fagfeller for nyttige innspill og kommentarer. Ansvaret for eventuelle svakheter ligger selvsagt hos oss. De utvalgte eksemplene bygger på forfatternes egne erfaringer.

\section{Referanser}

AAUP (American Association of University Professors) (2017). 1940 Statement of Principles on Academic Freedom and Tenure with 1970 Interpretive Comments. https://www.aaup.org/report/1940-statement-principles-academic-freedom-andtenure. Hentet 23.01.2017.

ABC Nyheter (2016). Geir Pollestad vil ha ny utredning om landbruk under TTIP. 8. november. https://www.abcnyheter.no/nyheter/2016/11/o8/195255142/ geir-pollestad-vil-ha-ny-utredning-om-norsk-landbruk-under-ttip). Hentet 28.03.2017.

Andersen, G. (2019). Forskningens betydning og begrensning i arbeidet med å etablere en økologisk forsvarlig petroleumsforvaltning. Denne boka.

Brekk, L.P. (2009). Kunnskapsbasert landbruksnæring. Leserinnlegg, Nationen 9. oktober.

Brekk, L.P., mfl. (2018). Evaluering av primærnæringsinstituttene. Hovedrapport. Lysaker: Norges forskningsråd.

Dagsavisen (2016). Tallkluss i skattekommisjon. Nyhetsartikkel, 12. mars.

FN (1966). International Covenant on Economic, Social and Cultural Rights. Genève: Forente Nasjoner.

Gezelius, S.S., mfl. (2009). NILFs forskere godtar ikke overstyring fra departementet. Leserinnlegg, Nationen 6. oktober.

Gezelius, S.S. (2010). Academic Freedom - What is it, Why do we need it? Foredrag, Universitetet i Oslo, september 2010.

Gezelius, S.S. (2012). Kan man ha akademisk frihet i et hierarki? Foredrag CIENS, Oslo, august 2012.

Gezelius, S.S., Hegrenes, A., \& Rustad, L.J. (2010). Gjennomgang av NILFs formidlingspolicy: Rapport fra intern arbeidsgruppe. Internt NILF-notat 2. februar 2010. Oslo: NILF. 
Giertsen, J. (2006). Akademisk frihet vs. arbeidsgivers styringsrett. Vedlegg 2 til NOU 2006: 19, Akademisk frihet - Individuelle rettigheter og institusjonelle styringsbehov. Oslo: Kunnskapsdepartementet.

Giertsen, J. (2006b). Akademisk ytringsfrihet. Vedlegg 1 til NOU 2006: 19, Akademisk frihet - Individuelle rettigheter og institusjonelle styringsbehov. Oslo: Kunnskapsdepartementet.

Kallerud, E. (2006). Akademisk frihet: en oversikt over spørsmål drøftet i internasjonal litteratur. Arbeidsnotat 18/2006. Oslo: NIFU STEP.

Merton, R. (1968). Science and democratic social structure. I R. Merton (red.), Social theory and social structure (s. 604-615). New York: The Free Press.

Nationen (2009a). Forsker kneblet av departement. Nyhetsartikkel, 29. september.

Nationen (2009b). Landbruksdepartementet støtter Nilf-henvendelsen. Nyhetsartikkel, 1. oktober.

Nationen (2009c). Forskningsfrihet opp i Stortinget. Nyhetsartikkel, 7. oktober.

Nationen (2017). Leder, 13. februar.

NENT (Den nasjonale forskningsetiske komité for naturvitenskap og teknologi) (2016). Forskningsetiske retningslinjer for naturvitenskap og teknologi. Oslo: NENT.

NESH (Den nasjonale forskningsetiske komité for samfunnsvitenskap og humaniora) (2016). Forskningsetiske retningslinjer for samfunnsvitenskap, humaniora, juss og teologi. Oslo: NESH.

NOU (Norges offentlige utredninger) (1999). «Ytringsfrihed bør finne sted»: Forslag til ny Grunnlov \$10o. NOU 1999: 27. Oslo: Statens forvaltningstjeneste.

NOU (Norges offentlige utredninger) (2006). Akademisk frihet - Individuelle rettigheter og institusjonelle styringsbehov. NOU 2006: 19. Oslo: Kunnskapsdepartementet.

Nydal, R., Solberg, B., \& Myskja, B. (2019). Interessekonflikter i forskning: Hva er det egentlig som står på spill? Denne boka.

Regjeringen (1961). Lov om opphavsrett til åndsverk m.v. Lov 1961-5-12-2. Oslo: Kulturdepartementet.

Regjeringen (1969). Lov om skadeerstatning. LOV-1969-06-13-26. Oslo: Justis- og beredskapsdepartementet.

Regjeringen (1992). Ot.prp. nr. 84 (1991-92). Om lov om endringer i lov 12 mai 1961 $n r .2$ om opphavsrett til åndsverk m.v. og i enkelte andre lover som følge av EØSavtalen. Oslo: Kulturdepartementet.

Regjeringen (2005). Lov om universiteter og høyskoler. Lov-2005-04-01-15. Oslo: Kunnskapsdepartementet.

Regjeringen (2005b). Lov om straff. LOV-2005-05-20-28. Oslo: Justis- og beredskapsdepartementet.

Regjeringen (2008). Retningslinjer for statlig basisfinansiering av forskningsinstitutter. FOR-2008-12-19-1579. Oslo: Kunnskapsdepartementet. 
Regjeringen (2010). Forskning i offentlege forvaltningsorgan og offentleglova. Brev 28. januar 2010. Oslo: Justis- og politidepartementet.

Regjeringen (2010b). Anvendelse av ny offentlighetslov i forskningsvirksomheter og forholdet til åndsverkloven. Brev april 2010. Oslo: Landbruks- og matdepartementet.

Regjeringen (2012). Etiske retningslinjer for statstjenesten. Oslo: Regjeringen. https://www.regjeringen.no/no/dokumenter/etiske-retningslinjer-forstatstjenesten/id88164/. Hentet 20.01.2017.

Regjeringen (2016). Prop. 158 L (2015-2016). Lov om organisering av forskningsetisk arbeid (Forskningsetikkloven). Oslo: Regjeringen.

Regjeringen (2017). Lov om organisering av forskningsetisk arbeid (forskningsetikkloven). LOV-2017-04-28-23. Oslo: Regjeringen.

Stortinget (2004). Innst. S. nr. 270 (2003-2004). Innstilling fra kontroll- og konstitusjonskomiteen om endring av Grunnloven $₫ 100$. Oslo: Stortinget.

Stortinget (2010). Innst. S. nr. 135 (2009-2010). Representantforslag om akademisk frihet for forskere. Oslo: Stortinget.

Torvund, O. (2010). Forskerforbundet: Opphavsrett. Skriftserien nr. 1/2010. Oslo: Forskerforbundet.

Torvund, O. (2017). Opphavsrett i oppdragsforhold. http://folk.uio.no/olavt/artikler/ oppdragsforhold.pdf Hentet 02.03.2017.

Tranøy, K.E. (1986). Vitenskapen - samfunnsmakt og livsform. Oslo: Universitetsforlaget.

Tranøy, K.E. (1995). Forskningsetikk for HF og SV - finnes det? I D. Elgesem \& J.E. Paulsen (red.), Seks innlegg om forskningsetikk i samfunnsfag og humaniora (s. 49-57). NESH skriftserie nr. 1. Oslo: NESH.

UNESCO (United Nations Educational, Scientific, and Cultural Organization) (1997). Recommendations concerning the status of Higher-Education Teaching Personnel. S. 26-35 i Records of the General Conference, $29^{\text {th }}$ Session, Vol. 1. Paris: UNESCO. 


\title{
KAPITTEL 3
}

\section{Interesse- og verdikonflikter i skjæringspunktet mellom patentetikk og forskningsetikk}

\author{
Anders Braarud Hanssen \\ Ph.d.-kandidat, OsloMet
}

\begin{abstract}
With the increased importance of patenting in emerging science and technology, publically funded research has also become increasingly influenced by commercial interests. In the wake of such developments central concerns within research ethics and patent ethics has gained new relevance. However, this has not materialized in research and patent policy debates in Norway. This paper provides an argument for the relevance of the rekindling of patent and research policy issues related to ethical and societal concerns for public research institutions in Norway. Further, due to an increasingly technocratic decision-making model of the patent system, important ethical and societal issues are left unanswered by current policy. This paper will focus on two aspects of current patent policy and practice. Firstly, the increased importance of commercial interests in research policy during the last 30 years has changed the incentives of public research. Secondly, patent law and the patent system has established a particular decision-making framework for how ethical and societal aspects of patents are addressed, particularly within the biopatent areas. This is exemplified with the evaluation of the AquaBounty-case in the Ethics Committee for Patent Cases. Furthermore, I discuss the relevance of the ethical responsibility of Norwegian public research institutions in current patent policy and how a range of complex ethical and societal issues evade public attention.
\end{abstract}

Keywords: patent policy, public research, research ethics, patent ethics, biotechnology, patent law

\section{Innledning}

Patentering har fått en stadig viktigere rolle innenfor de fleste vitenskapsog teknologiområder. Samtidig påvirkes forskningen i økende grad av 
kommersielle interesser. Denne utviklingen burde innebære at viktige forsknings- og patentetiske spørsmål blir diskutert. Imidlertid har dette ikke forsterket den forskningspolitiske debatten. Ellen Marie Forsberg gikk i en kronikk i bladet Forskningspolitikk så langt som til å si at situasjonen rundt patentpolitikken i Norge er preget av handlingslammelse. ${ }^{1}$

Patentsystemet er i utgangspunktet et fremmedelement innenfor offentlig finansiert forskning. Likevel vil vi selv i Norge oppleve at grunnleggende forskning, også innenfor områder med stor samfunnsmessig betydning, i økende grad blir hindret av kommersielle aktører gjennom patenter. Vi vil fortsette å erfare at disse patentene til tider har store samfunnsmessige og etiske implikasjoner vi sjelden får høre om, før lenge etter at patentet er innvilget. Denne utviklingen er delvis et resultat av at teknisk og juridisk ekspertise i patentsystemet tar avgjørelser om patentrettigheter på viktige samfunnsområder uten at dette blir gjort til gjenstand for demokratisk innsyn (Kica \& Groenendijk, 2011). Men utviklingen er trolig også et resultat av at forskningsinstitusjoner og forskere ikke er seg bevisst hvilke etiske og samfunnsmessige sider den nåværende patentpolitikken innebærer. Samtidig ser det ut til at den tilsynelatende åpenbare kontrasten mellom uavhengig og næringsrettet forskning er i ferd med å viskes ut. Kontrasten er tydeligst i dagens patentpraksis, hvor viktige etiske og samfunnsmessige spørsmål ofte faller utenfor.

I Norge har utviklingen bare så vidt startet. I USA har den allerede fått konsekvenser. I 2016 uttalte Facebook-gründer Mark Zuckerberg at selskapet planla å investere minst 3 milliarder dollar i å «kurere, behandle og forebygge all sykdom.»² Dette skulle skje gjennom opprettelsen av Bio$h u b$, et non-profit innovasjonssenter som samtidig skulle skaffe seg de immaterielle rettighetene som et ledd i å kommersialisere forskningen. Samtidig uttalte Microsoft at deres ambisjon var å «løse» kreftgåten innen 2026. Felles for disse og lignende satsinger er de tette båndene til teknologimiljøer i Silicon Valley, ${ }^{4}$ og troen på at overveldende komplekse

\footnotetext{
1 http://fpol.no/handlingslammelse-i-patentpolitikken/

2 https://www.theguardian.com/commentisfree/2016/sep/23/priscilla-chan-mark-zuckerberg-cure-diseases-facebook-initiative-brilliantly-bold 
medisinske problemstillinger kan reduseres til problemer med teknologisk løsning. Dette er imidlertid ikke hele historien. En mer sammensatt forklaring er at kunnskapsintensiv industri i USA er bygget sten for sten av langsiktige insentiv-løsninger, i det professor Mariana Mazzucato kaller den amerikanske «entreprenørstaten».5 Kort fortalt peker Mazzucato på det faktum at føderale finansieringsordninger ofte har vært hovedbidragsytere til de store innovasjonsløftene i amerikansk økonomi, deriblant suksess-historiene i Silicon Valley. Det som i en artikkel i Wall Street Journal ble kalt «The Jobs economy», ${ }^{6}$ er basert på et strategisk, forskningspolitisk skifte i USA på 1980-tallet.

Patentering er selve kjernen i disse selskapenes forretningsmodell. Patenter er blitt en handelsvare og en verdiindikator i seg selv (Odasso et al., 2014), samtidig som de blokkerer både konkurrenter og forskere fra å videreutvikle kunnskap (Mireles, 2004). Selv om vi her i landet ikke har samme vilkår for kommersialisering og patentering av forskning som i USA, er Norges forskningspolitikk likevel inspirert av amerikansk policy rundt immaterielle rettigheter knyttet til offentlig finansiert forskning (Bugge et al., 2003).

Jeg vil i hovedsak fokusere på to aspekter ved patentering og patentpraksis som henger tett sammen. Det ene er den styrkede rollen næringspolitiske hensyn har fått for forskningspolitikken de siste tretti årene, og som har endret både insentivordninger og rammer for forskningspolitikken. Dagens patentpraksis er et resultat av denne næringspolitiske vendingen. Den endrer rammevilkårene for den frie forskningen som skal komme samfunnet til gode, særlig i offentlige forskningsinstitusjoner. Det andre aspektet er hvordan patentlovgivning og patentsystemet setter rammer for måten etiske og samfunnsmessige sider ved patentering, særlig på bioteknologifeltet, blir behandlet. Dette vil bli eksemplifisert med den såkalte AquaBounty-sakens behandling i Den etiske nemnda for patentsaker (Patentnemnda). Avslutningsvis vil jeg peke på et hittil lite belyst aspekt ved dagens patentpolitikk og -etikk: De offentlige forskningsinstitusjonenes eget ansvar i dagens patentpraksis og (noen av)

5 https://www.ineteconomics.org/perspectives/blog/what-the-steve-jobs-movie-wont-tell-youabout-apples-success

6 https://www.wsj.com/articles/SB10001424052970203914304576628900383779840 
de mange komplekse etiske og samfunnsmessige spørsmålene som unndrar seg oppmerksomhet i dagens patentpolitikk.

\section{Entreprenørstatens patentpraksis og The Bayh-Dole Act}

Forskning innenfor såkalt muliggjørende teknologier som nano- og bioteknologi samt IKT spiller en viktig rolle i det økende forskningspolitiske presset om at forskningen skal være relevant og samfunnsnyttig. Samtidig er samfunnsnytten i økende grad forbundet med forskningens evne til å skape produkter, metoder og prosesser som kan gi økonomisk avkastning, også gjennom patenter. Forskningspolitiske føringer de siste tiårene har medført at også offentlig finansiert forskning blir vurdert ut fra sine muligheter for å kommersialisere forskningen. 7 I retningslinjene for Store programmer i Forskningsrådet er et av hovedkriteriene at programmene skal «frembringe FoU-resultater, teknologiplattformer og patenter der dette er relevant». ${ }^{8}$ Som en konsekvens av disse kommersielle insentivene prioriterer offentlige forskningsinstitusjoner mer næringsrettet forskning. Et sentralt spørsmål har vært hvordan disse institusjonene skal forholde seg til patentering av forskningsresultater.

Det er gammelt nytt at norske offentlige forskningsinstitusjoner ikke bare er kunnskapsutviklere, men også kunnskapsprodusenter. Nå er de i tillegg blitt juridiske eiere av kunnskap. ${ }^{9}$ En milepæl i denne utviklingen var endringene i universitets- og høyskoleloven samt arbeidstakeroppfinnelsesloven, som trådte i kraft i 2003, ${ }^{10} \mathrm{i}$ den hensikt å

øke den næringsmessige utnyttelse av de oppfinnelser som har sitt utspring i

forskning ved universiteter og høyskoler, uten at dette skal true institusjonenes

7 https://www.regjeringen.no/no/dokumenter/evaluering-av-virkemiddelapparatet-for-kommersialisering-av-offentlig-finansiert-forskning/id2481571/

8 https://www.forskningsradet.no/csstorage/vedlegg/storeprogrammer,o.pdf

9 Dette synet på kunnskap understrekes av regjeringens kunnskapsgrunnlag for universitets- og høyskolesektoren 2018: https://www.regjeringen.no/contentassets/e 7 b778c3b2aa439ca6288163a 98019c8/rapport-d.pdf

10 Ot.prp. nr. 67 (2001-2002) Om lov om endringer i lov av 17. april $1970 \mathrm{nr} .21 \mathrm{om}$ retten til oppfinnelser som er gjort av arbeidstakere. 
tradisjonelle oppgaver - fri forskning og høyere utdanning. (Ot.prp. nr. 67 (2001-2002))

Fra å søke ny kunnskap skulle norske offentlige forskningsinstitusjoner også bli entreprenører, med økt forventning om at forskning bør gi avkastning. Patentering ble i lovendringen ansett som det kanskje viktigste virkemiddelet i denne endringsprosessen.

En lite diskutert forhistorie til lovendringen i Norge, på lik linje med en rekke andre OECD-land, var et amerikansk lovforslag som gjorde offentlig finansiert forskning patenterbar av institusjonene selv.

Den såkalte Bayh-Dole Act eller Patent and Trademark Law Amendments Act, ratifisert i 1980, rettet seg mot immaterielle rettigheter forbundet med teknologi og kunnskap produsert gjennom føderalt finansiert forskning. ${ }^{11}$ Lovforslaget kom i kjølvannet av en økonomisk krise på 1970-tallet, som resulterte i en debatt om hvordan private selskaper mer effektivt kunne nyttiggjøre seg forskning. Lovens mål var å understøtte patentering og lisensiering fra amerikanske universiteter, som primært var føderalt hel- eller delfinansiert. Patenter er hovedsakelig en inntjeningskilde i form av lisensinntekter. Lisensiering av patenter skjer som regel i kraft av en avtale mellom eier av patentet og én eller flere lisenstakere om retten til å utnytte patentet, enten gjennom ny forskning ved hjelp av den patenterte kunnskapen eller teknologien, eller gjennom kommersiell videreutvikling. Med Bayh-Dole Act kunne universiteter, samt små og mellomstore bedrifter og non-profit-organisasjoner beholde lisensinntektene selv (Mowery et al., 2015), der disse tidligere hadde tilfalt føderale myndigheter.

Loven resulterte i en sterk vekst i patentering, og ble ansett som en overveldende suksess. Amerikanske universiteter økte sine lisensinntekter dramatisk, og kunne re-investere i forskningsprosjekter og infrastruktur (ibid.). Likevel var lovendringen kontroversiell, og er fremdeles gjenstand for debatt. Tilhengerne argumenterer for at lovendringen har medvirket til å skape hundretusener av arbeidsplasser, ${ }^{12}$ og at Bayh-Dole

\footnotetext{
11 Immaterielle rettigheter er den generiske termen for oppfinnelser, forfatter- og kunstnerarbeid, symboler, navn, logoer, design og andre innovasjoner. 
Act er forutsetningen for den forskningsbaserte industrien i USA. Denne loven har til og med blitt identifisert som selve grunnlaget for «the triple helix», det tette båndet mellom forskning, myndigheter og industri (Mowery et al., 2015). Kritikerne argumenterer på sin side med at lovendringen har medført at skattebetalerne betaler dobbelt for produkter og metoder de selv har finansiert gjennom skattepenger, og for dyre produkter og tjenester drevet frem av patentrettigheter (Hemel \& Ouellette, 2017). Andre kritiserer lovendringen fra et etisk perspektiv, og fokuserer på hensyn til rettferdig fordeling (ibid.), blant annet med argumenter som at patenterte produkter driver opp prisene i utviklingsland og rammer befolkningsgrupper med lav inntekt.

På midten av 200o-tallet hadde en rekke OECD-land, deriblant Norge, latt seg inspirere av Bayh-Dole Act med håp om tilsvarende effekt på næringsliv og verdiskaping, spesielt innenfor nye, forskningsdrevne områder som bioteknologi og farmasi. Flere land introduserte lovendringer som i store trekk forsøkte å tilpasse Bayh-Dole Act til nasjonale særinteresser, forskningsinfrastruktur, lovtekster og politiske situasjon. Lovendringene i Europa har derfor ikke hatt de samme rammevilkårene som i USA (Mowery et al., 2004). Likevel har det de siste 15 årene vært en gradvis økning i patentering på norske universiteter og høyskoler. Rapporten Kommersialisering av forskningsresultater, produsert på oppdrag av Norges Eksportråd i 2003, inneholdt følgende anbefaling:

Alle forskningsinstitusjoner bør, spesielt i en innledende fase, gjennom særskilte ekstrabevilgninger sikres mulighet til å beskytte frembrakt teknologi på et tidlig stadium, fortrinnsvis gjennom patentering. (Bugge et al., 2003)

Patentrettighetene innebærer potensielt økte lisensinntekter for sektoren, dog ikke uten at det oppstår komplekse forskningspolitiske og forskningsetiske utfordringer. Den offentlig finansierte forskningen er kunnskap som i utgangspunktet skal tilfalle offentligheten. Lovendringen endrer ikke på at det er forskningsinstitusjonene selv som er eiere av kunnskapen. Men kritikken mot kommersialisering av forskning i USA etter Bayh-Dole Act er overførbar til norske forskningsinstitusjoner. Her kan nevnes dobbel finansiering av offentlig forskning og hensyn til blant annet rettferdig fordeling. I tillegg er patentvirkemiddelet i seg selv 
dårlig tilpasset de forskningsområdene hvor patentering er mest fremtredende. Patentsystemet er utviklet for klassiske mekaniske oppfinnelser (Farnley et al., 2004), og er dårlig tilpasset for eksempel livsvitenskapene, som kjennetegnes av høy vitenskapelig usikkerhet og kompleksitet. Uten at dette er blitt tilstrekkelig diskutert i Norge, vil patentering av biologisk materiale medføre at statlige forskningsinstitusjoner blir juridiske eiere både av patentert kunnskap og av biologisk materiale. Dette er kunnskap som uten patentbeskyttelsen kunne tilfalt fremtidige generasjoner og være fritt være tilgjengelig for andre forskere. Slik kan eierskap til biologisk materiale komme i konflikt med de statlige forskingsinstitusjonenes frie rolle og samfunnsoppdrag.

\section{Hva er et patent, og hva er patentbart?}

Et patent gir innehaveren enerett til å utnytte en oppfinnelse kommersielt. I Norge blir søknad om patent behandlet av Patentstyret, i henhold til patentloven av 1967. Norge er medlem av Den europeiske patentorganisasjonen (EPO), og patentloven er underlagt European Patent Convention (EPC). Patentsøknader i EPC blir behandlet av The European Patent Office (EPO), men formelt godkjent av nasjonale patentkontorer. Patenter har som regel en varighet på tjue år, mens patenter på legemidler eller farmasøytiske produkter kan gis inntil fem års ekstra beskyttelsestid. Patenter vurderes på bakgrunn av patentlovens spesifikke hovedvilkår: Patentet må omfatte en oppfinnelse i kraft av en teknisk løsning på et problem, dvs. en fremgangsmåte eller et produkt (og ikke en oppdagelse); oppfinnelsen må ha industriell nytte, den må være ny (søknaden må ikke være allment kjent), og den må være nyskapende (dvs. ha tilstrekkelig "oppfinnelseshøyde» ${ }^{13}$ ) i relasjon til eksisterende dokumentert kunnskap når søknaden blir sendt. I tillegg må oppfinnelsen kunne fremstilles av en fagperson på bakgrunn av søknaden. Patentlovens $\$ 1$ første ledd setter også som et hovedvilkår at patent ikke meddeles dersom kommersiell

\footnotetext{
13 «Oppfinnelseshøyde» viser til at en oppfinnelse kun tilkjennes patent hvis patentkravene skiller seg vesentlig fra såkalt «kjent teknikk», dvs. det som er beskrevet i vitenskapelig eller teknisk litteratur, og i andre patentsøknader.
} 
utnyttelse av oppfinnelsen vil «stride mot offentlig orden og moral», og videre at:

Utnyttelse av en oppfinnelse skal ikke anses for å stride mot offentlig orden eller moral bare fordi den er forbudt ved lov eller forskrift.

Denne «unntaksparagrafen» avgrenser etiske og samfunnsmessige hensyn til «kommersiell utnyttelse». Det betyr at patent ikke kan nektes på grunnlag av etiske hensyn knyttet til produksjon og fremstilling av oppfinnelsen, men kun til hvordan patentet selv blir utnyttet. Patentloven gir også rom for at oppfinnelsens etiske og samfunnsmessige virkning ikke skal være definert av ulike nasjonale lover eller forskrifter. ${ }^{14}$ Med andre ord er denne paragrafens tolkningsramme forstått som «smal», men også tvetydig. «Offentlig orden og moral» er dessuten et nokså vagt begrep, men har historisk vært en integrert del av ulike nasjonale patentlovgivninger. Unntaksparagrafen henspeiler på oppfinnelser som i ulik grad er moralsk forkastelige, som f.eks. torturmetoder eller bomber, og forståelsen av begrepet er generelt beskrevet i retningslinjene ${ }^{15}$ til Patentstyret $^{16}$. Imidlertid ble det med integreringen av Biotek-direktivet i EPC gitt definisjoner av unntakskriterier for biologisk materiale som også ble gjeldende under $\$ 1$ i patentloven. På bakgrunn av denne unntaksparagrafen etterfølges første ledd av en rekke eksempler på spesifikke anvendelser og fremgangsmåter som ikke er utfyllende, men retningsangivende for unntak på bakgrunn av første ledd.

I 1980 avgjorde amerikansk høyesterett at levende organismer kunne patenteres. Dette førte til et slags etisk paradigmeskifte. Avgjørelsen gjaldt den nå ikoniske Diamond vs. Chakrabarty, ${ }^{17}$ som omhandlet patentkrav

14 Patentretningslinjene utdyper dette på følgende måte: «En av grunnene til dette er at et produkt, hvis utnyttelse er forbudt ved lov eller forskrift her i landet, skal kunne bli produsert her i landet for eksport til andre land hvor bruken av produktet ikke er forbudt. En annen grunn til dette, kan være at det kan komme endringer i den lov eller forskrift som regulerer utnyttelsen av oppfinnelsen, i løpet av patentets levetid» (Del C, IV 2.a.7).

15 Etter 2008 er patentloven harmonisert med Den europeiske patentkonvensjonen (EPC).

16 Patentretningslinjene for Patentstyret definerer unntaksparagrafen slik: «Hensikten med dette unntaket er å unnta fra patentering oppfinnelser som kan initiere opptøyer eller offentlig uorden, eller som kan lede til kriminalitet eller annen generell anstøtelig oppførsel. Bestemmelsen vil bare bli brukt i sjeldne og ekstreme tilfeller» (Del C, IV, 6.a.1).

https://supreme.justia.com/cases/federal/us/447/303/case.html 
på en genmodifisert bakterie utviklet for å bryte ned råolje. Patentet ble avvist - fordi datidens amerikanske patentlov ikke definerte levende organismer som oppfinnelser. Under ankesaken besluttet høyesterett å innvilge patentet og anså bakterien for å være en «komposisjon av materie» og ikke primært levende (s. 447). Dommen ble i praksis starten på den amerikanske bioteknologiindustrien (Straus, 2017). Den ble etterfulgt av en bølge av tilsvarende patentsøknader på levende organismer, også genmodifiserte dyr. Dommen var svært kontroversiell, og patentering av dyr og planter ble kritisert av religiøse ledere, dyrevernorganisasjoner, interesseorganisasjoner for bønder og miljøvernorganisasjoner. I etterkant ble tilsvarende praksis vanlig også i det europeiske patentsystemet, spesifisert gjennom innføringen av EUs direktiv 98/44/EF, det såkalte Biotek-direktivet. Ifølge dette er en mikrobiologisk prosess å anses som en oppfinnelse, og dermed patenterbar (Sterckx, 2017). Et slikt skille er ikke intuitivt, og det eksemplifiserer den juridiske og tekniske kompleksiteten som bioteknologispesifikke problemstillinger innenfor patentrett bærer preg av. Bak måten å formulere direktivet på ligger både eksplisitte og implisitte etiske problemstillinger som på mange måter berører forskningsetikk, og som kanskje egentlig er akkurat det (Resnik, 2011). For å få en bedre forståelse av hva disse problemstillingene innebærer, må vi se nærmere på hvordan etiske hensyn artikuleres og defineres i norsk og europeisk patentlov.

De eksplisitte etiske problemstillingene er relatert til de (relativt) smale rammevilkårene for hva som anses som moralske og samfunnsmessige hensyn (Tvedt, 2017), og er enda mer innsnevret av avgrensningen til kommersiell utnyttelse (Forsberg et al., 2018). De er ytterligere utdypet i unntakskriteriene i Biotek-direktivets Art. 6. I EPC er unntakskriteriene for biologisk materiale definert gjennom Regel 28, dyre- og plantearter samt «vesentlig biologiske fremgangsmåter for fremstilling av planter eller dyr» (Art. 53(b) EPC), eller metoder for behandling av menneskeeller dyrekroppen (Art. 53(c) EPC), som er ikke-patenterbare.

Avgrensningen i EPC om at loven kun gjelder kommersiell utnyttelse, avgrenser de fleste moralske hensyn til eierskapsspørsmålet (for biologisk materiale) og dets utnyttelse, men ikke til om oppfinnelsen er moralsk akseptabel (Sterckx, 2017). Med andre ord forvalter ikke patentloven i 
klartekst moralske hensyn forbundet med fremstillingsmetoder eller -prosesser. Likevel er det et uklart skille mellom hva som anses som henholdsvis utnyttelse og fremskaffelse av en oppfinnelse. Vi ser dette i flere ankesaker til EPO (Plomer, 2016). At tolkningen av «offentlig orden og moral» er snever, blir åpenbart når vi ser hvordan Biotek-direktivets unntakskriterier er implementert i norsk patentlov. Patentlovens $₫ 1 \mathrm{~b}$ tredje ledd utdyper unntaksparagrafen ved å eksemplifisere oppfinnelser som vil stride mot offentlig orden og moral:

- fremgangsmåter for kloning av mennesker,

- fremgangsmåter for å endre den genetiske identiteten til menneskers kjønnsceller,

- anvendelse av menneskelige embryoer for industrielle eller kommersielle formål, og

- fremgangsmåter for å endre den genetiske identiteten til dyr som kan påføre dem lidelser uten at det medfører noen vesentlig medisinsk nytte for mennesker eller dyr, samt dyr som er fremstilt ved slike fremgangsmåter.

Videre sier retningslinjene at genmodifiserte dyr og planter er patenterbare. Såfremt en plante eller et dyr ikke utgjør en enkelt plantesort eller dyrerase, og ikke er fremstilt gjennom en «vesentlig biologisk framgangsmåte», kan den patenteres. ${ }^{18}$ Søknader relatert til planter og dyr skal likevel vurderes i lys av $\$ 1 \mathrm{~b}$ hvis kravene er «etisk betenkelige». ${ }^{19}$

Det er lite rom for etiske og samfunnsmessige vurderinger i patentsystemet, utover unntakene uttalt i patentloven og EPC. Dette setter rammen for det vi kan kalle en «smal» fortolkning av unntakskriteriene for patenter på biologisk materiale, som viser seg i Patentstyrets og EPOs rettspraksis på området.

18 Patentstyret 2018, Patentretningslinjer, Del C, Kapittel IV 2a.3.2.3

19 Patentstyret 2018, Patentretningslinjer, Del C, Kapittel IV 2a.3.2 


\section{Implisitte etiske problemstillinger for biopatenter}

Praksisen med å snevre inn området for hva som er legitime etiske og samfunnsmessige spørsmål i patentsaker, har vært gjenstand for kritikk (Minssen \& Nordberg, 2015), og flere har argumentert for en utvidelse av rammene for relevante moralske problemstillinger (Forsberg et al., 2017). Dertil kommer en rekke implisitte etiske og samfunnsmessige problemstillinger i patentsystemet. Disse handler blant annet om etiske, miljømessige og samfunnsmessige konsekvenser av at definisjoner av sentrale begreper blir uklare eller forskjøvet. Dette gjelder f.eks. distinksjonen mellom det som er «naturlig» og «kunstig», og som har følger for skillet mellom oppfinnelse og oppdagelse. Patentsystemets mandat baserer seg på å gi nye oppfinnelser med samfunnsverdi et monopol på tjue år. Det er med andre ord en slags balanse mellom monopolet til patenthaver og den nytteverdien vi som samfunn får av oppfinnelsen. Dette utgjør det som av mange kalles patentsystemets samfunnskontrakt (Drahos, 2010). Her forutsettes det at patentsystemet skiller klart mellom hva som forstås som en oppfinnelse, og hva som forstås som en oppdagelse. Hvis noe ved lov umiddelbart skifter status fra å være naturlig forekommende til å anses som en oppfinnelse, oppstår også moralske spørsmål knyttet til eierskap, og til naturens egenverdi og allmennytte.

Hvilke etiske konsekvenser har det at informasjon fra naturlig forekommende materiale monopoliseres gjennom et patent? Problemstillingen kan oppstå når den genetiske informasjonen i en plante som har vært brukt til medisinske formål av en urbefolkning gjennom tusenvis av år, blir patentert, og patentet innebærer at utnyttelse av denne plantens egenskaper er lisenspliktig (Mgbeoji, 2014). Et annet implisitt etisk spørsmål i patentsystemet angår rettferdig fordeling av goder. Lisensiering gjennom patent kan medføre at et produkt blir mindre tilgjengelig for forskere, og at det blir dyrere for forbrukere enn det ville vært uten patentet. Et eksempel på dette er når pasientgrupper fra utviklingsland betaler en relativt sett mye høyere pris for en lisensiert vaksine enn de ville gjort dersom kunnskapen eller teknologien var fritt tilgjengelig (Sterckx, 2004). 
Videre er det aspekter ved dagens patentpraksis som tangerer både klassisk bioetiske og rent forskningsetiske problemstillinger. Særlig innenfor områder som genteknologi og syntetisk biologi utfordres skillet mellom kunstige og naturlige mekanismer. I noen tilfeller synes det endog å oppheves - med implikasjoner både for hva som kan eies, og for hvilken juridisk status eksempelvis et transgent dyr har (Pellizzoni, 2016). Felles for disse implisitte etiske problemstillingene er at de peker på aspekter ved dagens patentpraksis, spesielt innenfor biopatenter, som har samfunnskonsekvenser uavhengig av sin «kommersielle utnyttelse» og de snevre etiske vurderingene forankret i EPC eller patentloven. Slike spørsmål berører også en mulig konflikt med Mertons vitenskaplige normer (Eisenberg, 1987). Særlig Mertons vektlegging av «kommunisme», dvs. at forskersamfunnet skal kunne fritt dele og ha tilgang på all kunnskap som blir produsert til fellesskapets beste, står i direkte konflikt med patentsystemets normative grunnlag (Merton, 1973):

The communism of the scientific ethos is incompatible with the definition of technology as "private property" in a capitalistic economy. Current writings on the "frustration of science" reflect this conflict. Patents proclaim exclusive rights of use and, often, nonuse. The suppression of invention denies the rationale of scientific production and diffusion. (Merton, 1973, s. 275)

Selv om Mertons analyse er like aktuell i dag, har mye endret seg i takt med en voldsom teknologisk utvikling, en globalisert økonomi og et nyliberalt forsknings- og innovasjonssystem (Olsen \& Peters, 2005). David Resnik belyser i sin bok Price of Truth: How Money Affects the Norms of Science (Tyfield, 2008) utfordringene kommersialiseringen av forskning har fra et forskningsetisk standpunkt. Han peker på hvordan økonomiske interesser hos forskningsinstitusjonene kan undergrave generelle vitenskapelige normer som objektivitet, ærlighet, åpenhet, respekt og samfunnsansvar. I kjølvannet av patentinsentivenes økende betydning vil forskningen formes slik at den lettere lar seg patentere, og vitenskapelig usikkerhet og risiko vil bli skjøvet til side. Forskningsfunn som kunne vært viktige for andre forskningsområder, patenteres snarere enn å gjøres fritt tilgjengelig for videre forskning som kommer alle lag av samfunnet til gode. 
Kommersialiseringen av grunnforskning truer ikke bare grunnforskningens vesen. Den har i økende grad skapt grobunn for interessekonflikter som indirekte synliggjør andre forskningsetiske utfordringer. I Norge er det gjort lite forskning på interessekonflikter rundt kommersialisering og patenter blant forskere i Norge, men i USA har interessekonflikter og habilitetsspørsmål kommet til syne når forskere har unnlatt å identifisere økonomiske interesser i produkter eller prosesser i vitenskapelige publikasjoner (Gulbrandsen, 2003). Undersøkelser viser også at selv forskere som sitter i ekspertpaneler, unnlater å identifisere patentinteresser i en policy-anbefaling (Thorstensen, 2015). I så måte står vi ovenfor en interessekonflikt mellom den frie forskningens rolle i et demokratisk samfunn, og forskning som kommersiell aktør. I dette bildet har patentsystemet en premissleverende rolle for ny kunnskapsutvikling (Stone, 2017).

\section{Patentetikk vs. forskningsetikk}

Hvor går egentlig skillet mellom etiske hensyn i patentsystemet og i forskning? Det kanskje tydeligste tegnet på politiske, etiske og samfunnsmessige implikasjoner av gråsonen mellom forskningsetikk og patentrett finner vi i den politiske prosessen som ledet opp til EUs patentdirektiv 98/44/EF (Gitter, 2001) (Biotek-direktivet). Norge ratifiserte direktivet i januar 2004. ${ }^{20}$ Det var et virkemiddel fra EU-kommisjonen for å bygge en konkurransedyktig bioindustri i Europa (Thaker, 2003). I praksis innebar direktivet at muligheten for å tilkjenne eiendomsrett på biologiske materiale, inkludert kunnskap om menneskelig DNA, ble et faktum i Europa. Men siden dette var kontroversielt, ble det introdusert såkalte mottiltak da direktivet skulle integreres i norsk patentlov (Bioteknologinemnda, 2012). Introduksjonen av levende biologisk materiale i patentloven innebar nemlig en vesentlig endring av norsk patentpraksis. Ett av disse mottiltakene var opprettelsen av Den etiske nemnda for patentsaker.

I tråd med $\$ 15$ i patentloven er Den etiske nemnda for patentsaker (Patentnemnda) sitt mandat å bistå Patentstyret i saker der det er tvil 20 https://www.stortinget.no/no/Saker-og-publikasjoner/Publikasjoner/Innstillinger/Stortin-
get/2006-2007/inns-200607-253/2/ 
om anvendelsen av $\$_{1} \mathrm{~b}$ (De nasjonale forskningsetiske komiteene, 2008). Nemnda har kun fått én sak tilsendt fra Patentstyret, den såkalte AquaBounty-saken, som omhandlet genmodifisert laks. Denne saken er unik i patentetisk sammenheng, og eksemplifiserer skjæringspunktet mellom forskningsetiske og patentetiske problemstillinger. Samtidig viser den hvordan forskningsetikk og teknisk-juridiske beslutningsprosesser vanskelig lar seg forene. Saken ble vurdert i 2004, og nemndas anbefaling var å ikke innvilge patentet av hensyn til forurensningsfare og lidelse for fisken (ibid.). Imidlertid ble nemndas anmodning i hovedsak ikke tatt hensyn til, og patentet ble innvilget. AquaBounty-saken avdekket flere begrensninger i nemndas mandat og handlingsrom. Foruten rent patentjuridiske hensyn rundt fortolkningen av omfanget av $\$ 1$ bar en viktig hake ved nemndas anbefaling at den baserte seg på risikovurdering og vektlegging av føre var-prinsippet som sentrale argumenter for at patentet var i strid med $\$ 1 b$. Imidlertid var disse i forskningsetisk sammenheng legitime begrunnelsene ikke tilstrekkelige ifølge patentloven, hvor unntak fra patentbarhet pålegger slike argument en bevisbyrde, hvor i praksis forurensningsskade og dokumentasjon på at fisken lider, må fremlegges. I patentretningslinjene (Del C, Kap. IV, 2a.7.1) står det eksempelvis at unntak relatert til dyrs lidelser må underbygges med «bevis». ${ }^{21}$

Med tanke på begrensningene som ligger i det å kunne vitenskapelig dokumentere miljø- eller helseeffekter av oppfinnelser, er det i praksis sjelden mulig for en tredjepart å fremskaffe nøyaktig informasjon om den patenterte oppfinnelsen. Videre viste AquaBounty-saken at nemndas referanser til f.eks. dokumentert misdannelse hos andre transgene fisk ikke var adekvat dokumentasjon på det som ifølge patentretningslinjene er å anse som en annen oppfinnelse (De nasjonale forskningsetiske komiteene, 2008). Til slutt vil det ikke være i patentsøkers interesse å fremlegge bevis for at oppfinnelsen medfører lidelse eller miljøskade. I AquaBountysaken ble det i stedet fremlagt dokumentasjon som viste det motsatte, dog med veldig små datasett og ikke fagfellevurdert (ibid.). Dermed vil $\S 1 \mathrm{~b}$ i praksis ikke kunne anvendes, med mindre en klage på patentet 
inneholder faktiske forskningsdata fra den forelagte patentsøknaden, som forut for publisering av søknaden ofte vil være industrihemmeligheter. I tillegg er det uklart hvordan man kan vurdere slike søknader uten at de klart tangerer forskningsetisk regelverk eller regulering i kjølvannet av kommersialisering.

I nemdas begrunnelse ble særlig $\$ 1 \mathrm{~b}(3)$ vektlagt. Spesielt ble det påpekt at AquaBounty-laksen ikke hadde noen spesiell medisinsk nytte som kunne oppveie for lidelse hos fisken.

Hvis de spesifikke unntakene omtalt i $\$ 1 \mathrm{~b}(3)$ ikke viser til forskningsetiske problemstillinger ved selve fremstillingen av biologisk materiale, er loven uklar. I så måte har en rekke kritikere påpekt at den spesifikke unntaksparagrafen i Biotek-direktivet bør avskaffes - da den ikke handler om patentrett, men forskningsetikk (Van Overwalle, 2003). Nemndas rapport Patentnemd uten portefølje (2008) påpeker det paradoksale i at unntaksparagrafen er for smal til å adressere de sammensatte etiske og moralske problemstillingene som biopatenter innbefatter.

\section{Patentering av offentlig finansiert forskning: Hva er institusjonenes ansvar?}

Spenningsfeltet mellom forskningsetikk og patentetikk kan spores tilbake til det patentetiske paradigmeskiftet som Bayh-Dole Act og lignende lovendringer medførte for offentlig finansiert forskning. Der forskningsetikk og patentetikk overlapper hverandre, oppstår likevel - også i Norge - et problemområde som viser både tvetydigheten i patentloven og hvordan bredere moralske hensyn ikke blir fanget opp av en snever fortolkning av den. En kanskje enda mer aktuell problemstilling, hvor patenttekniske og etiske hensyn etablerer en gråsone, er i området hvor naturlig forekommende materiale blir patentert i kraft av en «teknisk prosess». Det er mulig å patentere biologisk materiale så lenge dette er en spesifikk del av en «teknisk løsning på et teknisk problem». Rent patentteknisk gjør dette skillet mellom oppfinnelser og oppdagelser irrelevant.

Videre har det juridiske eierskapet ikke klare geografiske grenser så lenge patentets omfang er klart spesifisert i patentkravene. Dermed er det i teorien fritt frem for en forskningsinstitusjon i Norge å ta patent på 
biologisk materiale hvor som helst i verden - og samtidig søke om patent i ulike patentjurisdiksjoner (som f.eks. EPC). Via isolering gjennom en teknisk prosess endres eierstatusen for noe som naturlig kunne anses å tilhøre menneskehetens felles biologiske arv eller kunnskapstradisjonen til urbefolkninger i ulike land (Mgbeoji, 2014).

Imidlertid finnes det også eksempler på at forskere benytter seg av patentvirkemiddelet på en implisitt «etisk» måte, da forskeren gis mulighet til å selv blokkere andre kommersielle aktører fra å utnytte patentrettighetene på en uetisk måte. I USA finnes en rekke eksempler på at humant genetisk materiale er patentert, men ikke utnyttet. På 1990-tallet var det et race for å sikre patentrettigheter i kjølvannet av sekvenseringsprogrammet til The Human Genome Project (Jensen \& Murray 2005). Mange av disse patentene hindrer ulike kommersielle aktører i å utnytte kunnskapen på en etisk tvilsom måte. Rent patentetisk er dette en utfordring innenfor EPOs (og Norges) patentjurisdiksjon. Den tekniske isolasjonsprosessen av gener har gjort etiske diskusjoner om et menneskelig gen kunne «eies», ugyldig, idet den genetiske informasjonen, gjennom å bli isolert, ikke korresponderer med dens naturlige gjenpart i menneskekroppen. I kontrast til denne praksisen ble det i USA, gjennom Myriad Genetics' patent på BRCA1- og BRCA2-genet (Caulfield et al., 2006) (knyttet til genmutasjoner forbundet med brystkreft), ført en appellsak i høyesterett hvor isoleringsprosessen ikke lenger ble definert som en oppfinnelse, idet juryen enstemmig vedtok at naturlig forekommende menneskelige gener ikke kunne patentbeskyttes. Patent kan kun gis for syntetisk fremkalte gener (Kesselheim et al., 2013). BRCA-patentet kunne satt kvinner med risiko for å bære BRCA-mutasjoner i en situasjon hvor de hadde måttet betale opptil 5000 dollar for å få testen vurdert av et laboratorium. ${ }^{22}$ I USA ville mange kvinner vært avhengige av særvilkår i forsikringsavtalene sine for å få råd til en slik test. Selv om dette patentet ble avvist i EPO Board of Appeals, har en rekke andre private bioteknologifirmaer lignende praksis for kommersielt å utnytte patentert genetisk informasjon relatert til diagnostiske metoder (Huys, 2011). Amerikansk høyesterett anerkjente den etiske gråsonen knyttet

http://www.breastcancer.org/symptoms/testing/genetic/facility_cost 
til at informasjonen $\mathrm{i}$ ett eller flere av kravene i et patent og informasjonen i naturlig forekommende gensekvenser i praksis er den samme, da den reverserte Myriad Genetics' patent. Likevel fortsetter europeiske og norske forskningsinstitusjoner å patentere gensekvenser. ${ }^{23}$ Med den smale fortolkningen av etiske og samfunnsmessige hensyn (Forsberg et al., 2018) i EPO og Patentstyret vil dermed en diskusjon om hvorvidt det er akseptabelt å patentere naturlig forekommende biologisk materiale, handle om tekniske demarkasjoner og ikke om samfunnseffekten av en slik praksis.

Dagens forskningspolitikk er også en form for næringspolitikk, og som eksemplene over viser, et område hvor kommersielle aktører i økende grad er med på å definere hvordan samfunnsutfordringer løses med forskning og innovasjon. Selv om dette er en uttalt og ønsket policy som også har vist seg å være vellykket på mange forskningsområder, står vi igjen med viktige forskningsetiske og patentetiske problemstillinger der få, kanskje ingen, kan gi gode svar på hvor grensene faktisk går. Årsakene til denne gråsonen mellom forskningspolitikk, patentpolitikk, etikk og samfunnsansvar er for mange til å gi en uttømmende redegjørelse. Noen av problemstillingene er direkte forbundet med patentsystemet og patentlovenes utforming og til relaterte beslutningsprosesser. Patentloven vil nødvendigvis «henge etter» den vitenskapelige og teknologiske utviklingen. Dette antyder at patent som virkemiddel kanskje ikke er optimalt tilpasset utviklingen på den bioteknologiske forskningsfronten, og særlig når det gjelder de samfunnsmessige konsekvensene. Imidlertid står også noen mer allmenngyldige hensyn igjen, som peker tilbake på aktørene selv: forskerne og forskningsinstitusjonene. Hvilket ansvar har den enkelte forsker for å selv å forstå, foregripe og ta inn over seg konsekvensene som $\$ 1 \mathrm{~b}$ og andre deler av patentloven prøver å forvalte? Hvilke forpliktelser ovenfor samfunnet har offentlige forskningsinstitusjoner rundt måten bioteknologi patenteres på?

På bioteknologifeltet formuleres de fleste patentkrav i en oppfinnelse med et reduksjonistisk språk, og biologiske prosesser blir beskrevet ut fra

23 https://www.regjeringen.no/contentassets/757447b34fb14f $458 \mathrm{cc} 8 \mathrm{fo} 5 \mathrm{e} 895638 \mathrm{cc} / \mathrm{no} / \mathrm{pdfs} / \mathrm{st}$ p20022003004300odddpdfs.pdf 
et molekylærbiologisk paradigme (Calvert, 2008). I møte med et patentsystem hvor også etiske og samfunnsmessige problemstillinger blir sett på som «ikke-tekniske» eksternaliteter, passer et slikt reduksjonistisk teoretisk rammeverk godt. Biotek-direktivets molekylærbiologiske forankring, sammen med EPO Board of Appeals' fortolkning av den samme reduksjonistiske modellen, preger hvordan etiske og samfunnsmessige problemstillinger blir vurdert, og hvordan moralske spørsmål innenfor biopatentfeltet forstås.

I hvilken grad kan forskningsinstitusjoner selv bli utfordret på forskningsetiske spørsmål som tangerer patentetikken? Spørsmål om nye typer transgene dyr har moralsk status, om hvordan patenter på naturlig forekommende genetisk materiale hindrer ny medisinsk forskning og innovasjon, og om i det hele tatt en isolasjon av en gensekvens kan anses som en oppfinnelse, forblir ubesvarte av patentsystemet selv. Man kan argumentere for at det nettopp er en slik reduksjonistisk modell som i siste instans undergraver muligheten for en bred debatt rundt samfunnseffekten av eierskapsspørsmål på biologisk materiale. De mer komplekse spørsmålene rundt vitenskapelig usikkerhet, verdikonflikter og mangel på involvering av andre former for ekspertise i patentsystemet får til slutt direkte samfunnsmessige konsekvenser. I siste instans utgjør dette et demokratisk problem som sannsynligvis vil øke i takt med den hurtige utviklingen innen bioteknologi.

\section{Hvor går vi videre?}

Tar vi et skritt tilbake til de mer overordnede etiske og forskningspolitiske implikasjonene av dagens patentpraksis i Norge, oppstår en rekke andre problemstillinger hvor interessekonflikter tilsynelatende spiller en viktig rolle. Dagens patentpraksis og den patentjuridiske ekspertisens hegemoni i patentvurderinger kan potensielt undergrave offentlige forskningsinstitusjoners legitimitet på sikt. På grunn av den manglende oppmerksomheten rundt patentetiske og forskningsetiske problemstillinger i kjølvannet av økt kommersialisering og patentering risikerer vi å få et forskningssystem som er i utakt med normer og verdier i befolkningen. Dette vil igjen kunne utfordre forskningens legitimitet og 
samfunnsrolle. Imidlertid har det norske patentsystemet allerede en etisk nemnd som i utgangspunktet kunne ha satt noen av de etiske spørsmålene om kommersialisering av kunnskap på dagsordenen. En mulig start på en bred offentlig debatt om forskningens fremtid og rolle i samfunnet kan være å sette søkelyset på patentsystemet som samfunnsaktør, med Patentnemnda som anfører i debatten om samfunnsmessige og etiske sider ved patentsystemet - langt utenfor en smal fortolkning av patentlovens unntaksbestemmelser.

\section{Referanser}

Bioteknologinemnda (2012). «Høring - endringer i patentloven m.m.» Letter to the Ministry of Justice and Public Security and Minstry of Trade and Industry, November 28. 2012.

Calvert, J. (2008). The commodification of emergence: systems biology, synthetic biology and intellectual property. BioSocieties, 3(4), 383-398.

Caulfield, T., Cook-Deegan, R.M., Kieff, F.S., \& Walsh, J.P. (2006). Evidence and anecdotes: an analysis of human gene patenting controversies. Nature biotechnology, 24(9), 1091.

Drahos, P. (2010). The global governance of knowledge: Patent offices and their clients. Cambridge: Cambridge University Press.

Eisenberg, R.S. (1987). Proprietary Rights and the Norms of Science in Biotechnology Research. Yale Law Journal, 97(2), 177-231.

Farnley, S., Morey-Nase, P., \& Sternfeld, D. (2004). Biotechnology - a challenge to the patent system. Current Opinion in Biotechnology, 15(3), 254-257.

Forsberg, E.M., Hanssen, A.B., Nielsen, H.M., \& Olesen, I. (2018). Patent ethics: The misalignment of views between the patent system and the wider society. Science and engineering ethics, 24(5), 1551-1576.

Forskningsetiske komiteer (red.) (2008). Patentnemnd uten portefølje? En analyse av etiske utfordringer ved patentering. Juli 2008. Oslo: De nasjonale forskningsetiske komiteene.

Gitter, D.M. (2001). Led astray by the moral compass: Incorporating morality into European Union biotechnology patent law. Berkeley J. Int'l L., 19, 1.

Gulbrandsen, M. (2003). «Jeg gjør jo ikke dette for å bli rik av det»: Kommersialisering av norsk universitetsforskning - en intervjustudie. NIFU Norsk institutt for studier av forskning og utdanning.

Hemel, D.J., \& Ouellette, L.L. (2017). Bayh-Dole beyond borders. Journal of Law and the Biosciences, 4(2), 282-310. 
Huys, I., Van Overwalle, G., \& Matthijs, G. (2011). Gene and genetic diagnostic method patent claims: A comparison under current European and US patent law. European Journal of Human Genetics, 19(10), 1104.

Jensen, K., \& Murray, F. (2005). Intellectual property landscape of the human genome. Science, 310(5746), 239-240.

Kesselheim, A.S., Cook-Deegan, R.M., Winickoff, D.E., \& Mello, M.M. (2013). Gene patenting - the Supreme Court finally speaks. The New England journal of medicine, 369(9), 869.

Kica, E., \& Groenendijk, N. (2011). The European patent system: Dealing with emerging technologies. Innovation: The European journal of social science research, 24(1-2), 85-105.

Merton, R.K. (1973). The sociology of science: Theoretical and empirical investigations. Chicago \& London: University of Chicago Press.

Mgbeoji, I. (2014). Global biopiracy: Patents, plants, and indigenous knowledge. Vancouver: UBC Press.

Milius, D., \& Townend, D. (2008). Thoughts on the scope and operation of morality clauses in patent law. Patentnemnd uten portefølje, 76-96.

Minssen, T., \& Nordberg, A. (2015). The Evolution of the CJEU's Case Law on Stem Cell Patents. NIR: Nordiskt immateriellt rättsskydd, 2015(5), 493-503.

Mireles, M.S. (2004). An examination of patents, licensing, research tools, and the tragedy of the anticommons in biotechnology innovation. U. Mich. JL Reform, $38,141$.

Mowery, D.C., Nelson, R.R., Sampat, B.N., \& Ziedonis, A.A. (2015). Ivory tower and industrial innovation: University-industry technology transfer before and after the Bayh-Dole Act. Stanford University Press.

Mowery, D.C., \& Sampat, B.N. (2004). The Bayh-Dole Act of 1980 and universityindustry technology transfer: A model for other OECD governments? The Journal of Technology Transfer, 30(1-2), 115-127.

Odasso, C., Scellato, G., \& Ughetto, E. (2014). Selling patents at auction: an empirical analysis of patent value. Industrial and Corporate Change, 24(2), 417-438.

Olssen, M., \& Peters, M.A. (2005). Neoliberalism, higher education and the knowledge economy: From the free market to knowledge capitalism. Journal of education policy, 20(3), 313-345.

Pellizzoni, Luigi. Ontological politics in a disposable world: The new mastery of nature. Routledge, 2016.

Plomer, A. (2016). The European Union's IP policy and funding of stem cell research. I D. Matthews \& H. Zech (Red.) (2017). Research Handbook on Intellectual Property and the Life Sciences. Edward Elgar Publishing, 229-243. 
Resnik, D.B. (2011). What is ethics in research \& why is it important. National Institute of Environmental Health Sciences, 1-10.

Straus, J. (2017). Intellectual property rights and bioeconomy. Journal of intellectual Property Law \& Practice, (7), 576-590.

Sterckx, S. (2004). Patents and access to drugs in developing countries: An ethical analysis. Developing World Bioethics, 4(1), 58-75.

Sterckx, S. (200o). Biotechnology, Patents and Morality. London: Routledge, https:// doi.org/10.4324/9781315188805.

Stone, G.D. (2017). Dreading CRISPR: GMOs, honest brokers, and mertonian transgressions. Geographical Review, 107(4), 584-591.

Thaker, S. (2003). The criticality of non-market strategies: The European Biotechnology Patents Directive. Northwestern University, Kellogg School of Management, Online Research Paper on Biotechnology, available on the following address: http://www. kellogg. northwestern. edu/academic/biotech/articles/shail. pdf.

Thorstensen, E. (2015). Patent-holders on expert committees. Can there be a conflict of interest? Etikk i praksis-Nordic Journal of Applied Ethics, (1), 55-72.

Tyfield, D. (2008). The Price of Truth: How Money Affects the Norms of Science, David Resnik. Oxford University Press, 2007, xiii+224 pages. Economics \& Philosophy, 24(1), 123-129.

Tvedt, M.W., \& Forsberg, E.M. (2017). The room for ethical considerations in patent law applied to biotechnology. The Journal of World Intellectual Property, 2o(5-6), $160-177$.

Van Overwalle, G. (2003). Legal and ethical aspects of bio-patenting. A critical analysis of the EU biotechnology directive. I C. Baumgartner \& D. Mieth (Red..), Patente am Leben? Ethische rechtliche und politische Aspekte der Biopatentierung. Mentis, Paderborn, 145-158.

\section{Nettressurser}

1. http://fpol.no/handlingslammelse-i-patentpolitikken/

2. https://www.theguardian.com/commentisfree/2016/sep/23/priscilla-chan-markzuckerberg-cure-diseases-facebook-initiative-brilliantly-bold

3. https://www.telegraph.co.uk/science/2016/o9/20/microsoft-will-solve-cancer-within-10-years-by-reprogramming-dis/

4. https://harvardmagazine.com/2017/o7/probing-psychoses

5. https://www.ineteconomics.org/perspectives/blog/what-the-steve-jobs-moviewont-tell-you-about-apples-success

6. https://www.wsj.com/articles/SB10001424052970203914304576628900383779840

7. https://www.regjeringen.no/no/dokumenter/evaluering-av-virkemiddelapparatet-for-kommersialisering-av-offentlig-finansiert-forskning/id2481571/ 
8. https://www.forskningsradet.no/csstorage/vedlegg/storeprogrammer,o.pdf https://www.regjeringen.no/contentassets/e7b778c3b2aa439ca6288163a98019c8/ rapport-d.pdf

9. Ot.prp. nr. 67 (2001-2002). Om lov om endringer i lov av 17. april 1970 nr. 21 om retten til oppfinnelser som er gjort av arbeidstakere

10. http://www.ipwatchdog.com/2012/11/o3/why-bipartisanship-matters/

11. https://supreme.justia.com/cases/federal/us/447/303/case.html

12. Patentstyret 2018, Patentretningslinjer, Del C, Kapittel IV 2a.3.2.3

13. Patentstyret 2018, Patentretningslinjer, Del C, Kapittel IV 2a.3.2

14. https://www.stortinget.no/no/Saker-og-publikasjoner/Publikasjoner/Innstillinger/Stortinget/2006-2007/inns-200607-253/2/

15. https://www.patentstyret.no/tjenester/patent/patentretningslinjer/utvalg/del-c/ del-c-realitetsbehandling-kap-iv---vurdering-av-patenterbar/\#_Toc506376460

16. http://www.breastcancer.org/symptoms/testing/genetic/facility_cost

17. https://www.regjeringen.no/contentassets/757447b34fb14f $458 \mathrm{cc} 8 \mathrm{fo} 5 \mathrm{e} 895638 \mathrm{cc} /$ no/pdfs/stp20022003004300odddpdfs.pdf 


\title{
KAPITTEL 4
}

\section{Den skjulte styringen}

Ketil Skogen, seniorforsker

Norsk institutt for naturforskning

Audun Ruud, seniorforsker

Norsk institutt for naturforskning

Olve Krange, seniorforsker

Norsk institutt for naturforskning

\begin{abstract}
Lately, we have seen several overt attempts from politicians and corporate interests to steer research in the directions they prefer. However, such attempts are always met with outrage and resistance, and they lead to extensive public debate. We contend that more subtle and hidden control over research is exercised on a day-today basis, yet it is rarely discussed. Research programs and new research centers are often designed based on premises that are no less political than clumsy attempts at controlling scientists. Programs are designed to stimulate economic growth, energy production, commodification, job creation, a more effective government, etc. These premises are rarely articulated and almost never discussed. Many Norwegian and EU research programs will automatically exclude research that questions them. This means that only research that is "useful" for particular interests is funded. The claim that this form of "usefulness" is universally good is in fact strongly political. This hidden political control impairs our possibilities to conduct research to facilitate alternative societal development trajectories and serve civic society. It should be discussed much more openly and critically than is the case today.
\end{abstract}

Keywords: research policy, power relations, politics

\section{Introduksjon}

Da Per Sandberg for en tid siden proklamerte at Havforskningsinstituttet værsågod hadde å være «næringsvennlig» og forske for å gjennomføre

Sitering av dette kapitlet: Skogen, K., Ruud, A., \& Krange, O. (2019). Den skjulte styringen. I H. Ingierd, I. Bay-Larsen \& K. Hiis Hauge (Red.), Interessekonflikter i forskning (s. 91-105). Oslo: Cappelen Damm Akademisk. https://doi.org/10.23865/noasp.63.ch4

Lisens: CC BY 4.0 
regjeringens politikk, samtidig som han kalte kritiske forskere for «mørke krefter», ${ }^{1}$ ble han møtt med en storm av kritikk. ${ }^{2}$ Det har vært flere lignende tilfeller i det siste, der folk i maktposisjoner forsøker å styre forskning eller mistenkeliggjøre forskeres motiver og integritet. Norske Sjømatbedrifters Landsforenings diskreditering av lakseforskningen er et urovekkende eksempel. ${ }^{3}$ Her har vår egen forskningsinstitusjon fått unngjelde. ${ }^{4}$ Dette er en tiltagende og farlig tendens, som ikke på noen måte er begrenset til Norge, men det skjer som regel ikke uten at det reises kritikk. Derfor kan vi si at kritikken av Sandberg var en positiv effekt av ministerens eiendommelige manøver. Sandberg skapte en anledning til å diskutere og synliggjøre - for en bredere offentlighet - betydningen av forskningens uavhengighet og viktigheten av vitenskapens universelle ideal om akademisk frihet. Han aktualiserte en diskusjon om den vitenskapelige kunnskapsproduksjonens stilling overfor mektige aktører som staten, store industriforetak og andre med stor innflytelse i det norske samfunnet. Vi mener imidlertid at et viktig element har manglet i denne diskusjonen. Hvordan styres forskningen i det daglige, når styringen ikke er like åpenlys? Hvem setter dagsorden, og hvilke idéer og problemstillinger blir vektlagt? Finnes det uuttalte premisser som gjør at forskning som tjener bestemte formål, finansieres, selv om premisser og formål kunne og burde problematiseres?

Det er spørsmål som dette vi vil lufte her. Målet er å reise en debatt, basert på egne erfaringer med forskningsfinansiering, og på eksempler hentet fra programplaner og andre forskningspolitiske dokumenter. Disse eksemplene gir ikke et uttømmende bilde av premissene som styrer finansieringen av norsk forskning, men de tydeliggjør problemene vi vil belyse.

En sentral målsetting for norsk forskning er å sikre dens autonomi. Da Norges forskningsråd ble opprettet i 1993, ble det lagt stor vekt på at forskning skulle være forskerstyrt. Vår egen og våre kollegers erfaring

1 http://www.aftenposten.no/norge/politikk/Varsler-oppgjor-med-morke-motkrefter-10792b. html

2 http://www.aftenposten.no/norge/Per-Sandberg-advarte-mot-morke-motkrefter---skaptestorm-24711b.html

3 https://fiskeribladet.no/nyheter/?artikkel=45570

4 http://www.nina.no/Aktuelt/Nyhetsartikkel/ArticleId/3845/Usaklige-beskyldninger-fra-Norske-Sjomatbedrifters-Landsforening-NSL 
er ofte en annen. I Norge, som i mange andre land, er finansieringen organisert $i$ et system som utfordrer og til og med truer institusjonenes nødvendige autonomi. Systemet gir nemlig rom for en maktutøvelse som ikke er like iøynefallende som Sandbergs overtramp, men ikke desto mindre svært effektiv. Det er slike subtile og mindre synlige måter å styre forskningen på det skal handle om i dette kapitlet. Vi vil se nærmere på hvordan forskning kan tilpasses bestemte interesser eller perspektiver, også når finansieringskilden er offentlig. Den makten som ligger i å avgrense hva slags forskning som finansieres, fortjener større oppmerksomhet. Det finnes et grunnlag for utøvelse av makt i måten programmene utformes og gjennomføres på, og som legger sterke føringer på hva det faktisk utvikles kunnskap om, og hva slags innsikt og forståelse som genereres. Vi ser det ofte i utlysningene på vårt eget felt, miljøforskningen. Det kan igjen få stor betydningen for hvilken rolle forskningen kan ha i samfunnet. Kritisk forskning kan for eksempel være svært nyttig, om enn på andre måter enn de vi normalt finner formulert i programplaner og utlysningstekster. At forskning som ikke i utgangspunktet motiveres av nyttehensyn (typisk «grunnforskning»), faktisk kan vise seg å bli svært verdifull i framtida, er et synspunkt som ofte framsettes i debatten. Det er vi selvsagt enige $i$, men poenget vårt er snarere at kritisk forskning også kan ha stor nytteverdi på kort sikt - men kanskje for andre enn de som i dag legger føringene når forskningsprogrammer utformes og bevilgningsbeslutninger fattes.

\section{Styring mot bestemte typer «nytte»}

Det er vanlig at Norges forskningsråd (NFR) i sine programmer stiller krav om samfunnsnytte - at forskningen er til gagn for samfunnet. Det samme gjør EU i sin store forskningssatsing Horizon 2020. Og det er ikke urimelig. Forskning finansieres i stor grad over offentlige budsjetter, og bruk av fellesskapets ressurser bør selvsagt på en eller annen måte komme fellesskapet til gode. At forskning skal være nyttig, er vel og bra, men vi må stille spørsmål om hva slags nytte den gir. Denne kan være mer eller mindre klart definert. Hva som er nyttig, kan spesifiseres på ganske snevre måter, eller peke vagt i visse retninger, men har unngåelig en 
innretning som bygger på bestemte politiske perspektiver eller tilgodeser konkrete interesser. Til dette hører selvsagt spørsmålet om hvem som får bestemme hva som er nyttig. Konsekvensen er at forskningsprosjekter som når opp i konkurransen og som finansieres med offentlige midler gjennom slike programmer, vil være preget av en bestemt tolkning og operasjonalisering av nettopp dette. Ofte er det forskning for gode formål som finansieres. Det kan f.eks. være å redusere forurensende utslipp eller gjøre samfunnet bedre i stand til å tilpasse seg klimaendringer. Tilsvarende kan det være gode prosjekter om mer miljøvennlig utnyttelse av naturressurser, utvikling av bedre teknologi innenfor et bestemt område eller modellutvikling knyttet til bedre forståelse av framtidig produksjon og forbruk. Slike prosjekter kan være både gode og relevante, men vårt poeng er at det er like stort behov for andre typer kunnskap.

Et sentralt spørsmål er hvem forskningen skal være nyttig for. Det kan være mange som vil ha stor nytte av forskning som imøtegår de underforståtte premissene som preger en rekke av dagens forskningsprogrammer. «Samfunnet» er ikke ensbetydende med myndighetene og næringslivet, men inkluderer også interesser som i mindre grad har ressurser til å søke (nyttige) forskningssvar på viktige spørsmål.

Siste langtidsplan for forskning og utdanning ble presentert av Solberg-regjeringen i oktober 2015. Den fastsetter overordnede mål og prioriteringer for hvordan regjeringen skal styrke forskning og høyere utdanning i perioden 2015-2024. Her fokuseres det på styrket konkurransekraft og innovasjonsevne, men samtidig understrekes betydningen av å løse store samfunnsutfordringer. ${ }^{5}$ Men det gir seg slett ikke selv hvilke samfunnsutfordringer forskningen skal hjelpe til med å løse, og på hvilken måte det skal skje.

Sivilsamfunnet i alt sitt mangfold trenger også nyttig forskning, men det kan være forskning som søker andre svar enn samfunnets tradisjonelle premissleverandører etterspør. Dersom den offentlig finansierte forskningens programmer strømlinjeformes for å gi en bestemt type svar som er viktig for enkelte samfunnsaktører, og det ikke åpnes for 
forskning som på andre måter kan være avgjørende for samfunnsutviklingen, utgjør dette etter vårt syn ikke bare et problem for forskningen og forskerne. Det vil også være et alvorlig demokratisk problem. Forskning reduseres da til en virksomhet som bare øker innflytelsen til de som allerede har makt. Et velfungerende demokrati er avhengig av en kunnskapsproduksjon hvor problemstillingene åpner for å utfordre makt, markedsløsninger, næringsinteresser og gjeldende sannheter i sin store alminnelighet.

\section{Skjevt forskningsfokus}

I overfloden av gode, konkrete, praktisk nyttige «best praksis-prosjekter» er det ofte liten plass til forskning som stiller grunnleggende kritiske spørsmål - også ved de nyttebetraktninger som finnes i forskningsprogrammenes utlysninger. Vi kan igjen ta forskning som berører havbruksnæringen som eksempel. I seg selv er det selvsagt ikke noe galt i forskning som bidrar til en bedre praksis i næringen: Mindre bruk av antibiotika, reduksjon av lakselusproblemet, kostnadseffektivisering og optimalisering av produksjonen. Og det er heller ingen grunn til å kritisere at den forskningen næringen selv finansierer, hovedsakelig dreier som om slikt som kan bedre lønnsomheten, eller svarer på miljøkrav som myndighetene stiller. Problemet oppstår først og fremst når offentlige midler (folkets felles ressurser) brukes til det samme formålet. Og det skjer selv om næringen har økonomi til å finansiere denne typen kunnskapsproduksjon. Det norske samfunnet, og dessuten næringen selv, fortjener (og har potensielt stor nytte av) forskning som setter et kritisk søkelys på problemene næringen kan skape. Naturvitenskapelige problemstillinger som dreier seg om næringenes virkning på økosystemene, eller samfunnsvitenskapelige problemstillinger om maktforhold, næringens politiske innflytelse, økende kapitalkonsentrasjon og en rekke andre temaer, kan lede til bedre opplysning av samfunnsdebatten. Hvis vi er heldige, kan de også føre til bedre politiske beslutninger. Disse beslutningene vil også være påvirket av andre samfunnsaktører enn næringen selv og sektormyndighetene, samfunnsaktører som vil ha stor nytte av forskning som kaster lys over problemstillinger som er viktige for dem. Det kan imidlertid være 
problemstillinger som avviker, kanskje betraktelig, fra slike som næringen selv og deres støttespillere er interessert i. Forskning kan i noen tilfeller bidra til å undergrave havbruksnæringen slik den drives i dag. Det kan i seg selv ikke være problematisk for offentlig finansiert forskning. Verken på universitetene eller i forskningsinstituttene kan virksomheten begrenses til bare å levere «best praksis-resultater» på snevert avgrensede premisser, ofte innrettet mot såkalt verdiskaping (i seg selv et sterkt politisert begrep som klart viser at «språk er makt»). Det er dette vi mener å se tydelig i mange programplaner, utlysninger og ofte i valg av prosjekter som faktisk støttes. Dette er det all grunn til å advare mot.

\section{Åpenhet om premisser for prioritering}

Det er ikke noe nytt, og heller ikke til å unngå, at det ligger forutsetninger og bestemte problemforståelser i programplaner og utlysninger, og at de bygger på politiske premisser og forutsetninger. Mange ønsker å stimulere til forskning med bestemte siktemål på definerte områder, slik også Per Sandberg ønsket. Dette er nærmest en triviell innsikt fra studier av forskningspolitikk. Men ikke minst derfor er det urovekkende at disse premissene ikke gjøres eksplisitte, og at de sjelden settes under debatt, for eksempel med utgangspunkt i studier av forskningspolitikk og makt. Det er derfor vi reiser spørsmål i dette bidraget: Hva slags samfunnsutvikling er det offentlige forskningsmidler skal være med å støtte eller rettferdiggjøre? Hva slags kunnskap er det viktig at knappe ressurser bidrar til å frambringe? Selv om mange forskningsprogrammer starter med høringsrunder, og selv om programplaner utvikles etter innspill utenfra, er vårt klare inntrykk at de grunnleggende premissene forblir uendret, beholder en bestemt politisk innretning og bygger på bestemte verdigrunnlag. Et aktuelt eksempel er forutsetninger om «grønn økonomisk vekst» eller «grønn omstilling i næringslivet», og ikke minst «bærekraftig samfunnsutvikling». Dette er ikke nøytrale, apolitiske målsettinger. Alle kan være enige $i$ at det høres finere ut med grønn enn f.eks. svart vekst, og at bærekraft høres bra ut. Dersom det imidlertid er selve veksten som er problemet, vil fokus på fargen snarere enn vekstbegrepet hindre helt nødvendig forskning som kan være avgjørende for videre samfunnsutvikling og i 
ytterste konsekvens menneskehetens overlevelse - noe vi normalt forbinder med bærekraftig utvikling. Dette er noe annet og mer fundamentalt enn omstilling i næringslivet, som kan være et middel, men ikke et mål i seg selv. I hvor stor grad en slik omstilling i det hele tatt kan skje i en markedsøkonomi og samtidig være forenlig med økonomisk vekst, må være et spørsmål som ikke bare er legitimt, men helt grunnleggende. Derfor er forskning som stiller slike spørsmål også nyttig - i en svært fundamental betydning av ordet.

Både i samfunnsdebatten og i akademia er dette et tema som faktisk får mye oppmerksomhet: Er vedvarende økonomisk vekst, og en markedsøkonomi av vår type, egentlig ondets rot? Er det mulig å forene fortsatt vekst med bærekraftige løsninger, økologisk så vel som sosialt? Noen svarer nei, også blant økonomer og andre innen den delen av akademia som har frihet til å drive med kritisk vitenskap. Den såkalt «degrowth»bevegelsen er vital, og mange med bakgrunn fra forskning deltar der. Sosial bærekraft, eller sosial rettferdighet, er ikke mindre viktig enn den $ø$ kologiske. Her er det åpenbart at dagens økonomiske system må opp til diskusjon. Å forutsette at bærekraft kan oppnås uten fundamentale samfunnsendringer, er ikke mindre politisk enn å hevde det motsatte. Arbeid for å forandre en planøkonomi til en markedsøkonomi - la oss si i Øst-Europa på 1980-tallet - vil av de fleste betraktes som politisk virksomhet. I vår tid er den samme markedsøkonomiens grunnlogikk førende for nesten alt myndighetene foretar seg - også forskningsfinansiering. Selv de som mener at det er riktig, bør erkjenne at det også er politisk. Men i NFRs dokumenter ligger dette politiske grunnlaget stort sett ukommentert, som om det skulle være en naturtilstand, en slags «end of history». Dette er enten en naiv forestilling eller et uttrykk for at bestemte krefter faktisk styrer forskningen - eller begge deler.

Det finnes eksempler på at oppdragsforskning har vært påvirket av hva oppdragsgivere ønsker av resultater, men her snakker vi om produksjon av kunnskap som finansieres av samfunnet, altså med alle samfunnsmedlemmers felles ressurser. Da må vi forvente at det samme samfunnet får utført forskning i en bredde som faktisk kan sikre viktig og relevant kunnskap - også på lengre sikt, og som kan være nyttig for sivilsamfunnet så vel som for myndigheter og næringsliv. 
På Forskningsrådets hjemmesider og på hjemmesidene til EUs Horizon 2020 florerer eksempler på denne styringen mot bestemte typer forskning som kan søke om finansiering. Å finne fram på slike nettsteder er ikke alltid like enkelt, men vi har sett på en del programplaner, utlysninger og generelle målsettinger. Denne gjennomgangen er ikke på noen måte uttømmende, men hovedinntrykket er at lite synlige premisser gjennomsyrer mange av disse tekstene. I en del programmer gjøres premissene for så vidt eksplisitte i den forstand at det står tydelig hva målet er, men ikke slik at det gjøres klart at noen valg er tatt, og på hvilket grunnlag. Langt mindre åpnes det for forskning som kan stille spørsmålstegn ved disse premissene. Horizon 2020 er i en klasse for seg. Om hele denne enorme satsingen heter det bl.a.:

Horizon 2020 is the financial instrument implementing the Innovation Union, a Europe 2020 flagship initiative aimed at securing Europe's global competitiveness. Seen as a means to drive economic growth and create jobs, Horizon 2020 has the political backing of Europe's leaders and the Members of the European Parliament. They agreed that research is an investment in our future and so put it at the heart of the EU's blueprint for smart, sustainable and inclusive growth and jobs. ${ }^{6}$

På et felt som er aktuelt for vårt institutt, NINA, nemlig «Climate Action, Environment, Resource Efficiency and Raw Materials», heter det i den generelle omtalen:

Reducing resource use and environmental impacts, whilst increasing competitiveness, will require a decisive societal and technological transition to an economy based on a sustainable relationship between nature and human well-being. (...) Innovation in these fields will provide opportunities for growth and jobs, as well as innovative options involving science, technology including of ICT, the economy, society, policy and governance. ${ }^{7}$

Vi vet at Horizon 2020 også krever «impact», altså at det skal vises hvordan forskningen faktisk bidrar til framgangen EU ønsker, og dessuten

6 https://ec.europa.eu/programmes/horizon2020/en/what-horizon-2020

7 https://ec.europa.eu/programmes/horizon2020/en/h2020-section/climate-action-environment-resource-efficiency-and-raw-materials 
stilles det som betingelse at kommersielle aktører deltar i prosjektene. Innretningen framstår som klar, men helt uten diskusjon eller begrunnelse. Vekst og konkurransedyktighet ses åpenbart som målsettinger det er unødvendig å diskutere, også for miljøforskningen.

I 2015 vedtok Forskningsrådets hovedstyre hovedstrategien som skal gjelde for perioden 2015-2020. På NFRs egne hjemmesider kommenterte styrets leder Henrik O. Madsen den nye strategien. ${ }^{8}$ Han framholdt «hvor viktig forskning og innovasjon er for samfunnsutviklingen», og satte opp tidligere strategier som kontrast. De hadde nemlig «lagt større vekt på forskningen som et mål i seg selv». Nå har man vedtatt «en strategi som understreker tydeligere enn før hvor avgjørende god forskning og innovasjon vil være i den omstillingsprosessen norsk økonomi må gjennom de nærmeste tiårene». Forskningen skal ha som hovedoppgave å bidra med løsninger, gjerne - og kanskje helst - i samarbeid med næringslivet. Spørsmålet om vår type økonomi i det hele tatt kan bli «bærekraftig» i noen betydning av ordet, har tydeligvis ikke hatt noe sentral plass i strategiutviklingen, og forskning på områder som ikke hjelper næringslivet til «omstilling», nedprioriteres åpenlyst.

Inntrykket av at nyttig kritisk forskning sjelden prioriteres, styrkes dersom man ser nærmere på noen programmer finansiert av Norges forskningsråd. EnergiX-programmet er et av de største - med et årlig budsjett på nesten 500 millioner i 2017. Programmet er næringsorientert, men støtter forskning på fornybar energi generelt, effektiv energibruk samt energisystemer og energipolitikk. I siste tildeling ga EnergiX-programmet støtte til 55 nye prosjekter, der de fleste er samfinansiert med brukere i såkalte innovasjonsprosjekter (IPN) eller kompetanseprosjekter (KPN). Det ble imidlertid også innvilget 13 forskerprosjekter uten krav til brukerfinansiering. Disse finansieres i sin helhet av offentlige midler. Prosjektene som velges ut, må naturlig nok skåre høyt på vitenskapelige kriterier. Samtidig understreker EnergiX at prosjekter som skal støttes, bør ha høy relevans for utfordringene på energiområdet. Det er også naturlig, men vi noterer at det er et kriterium at prosjektene skal gi kompetanse

8 https://www.forskningsradet.no/no/Nyheter/Ny_hovedstrategi_er_klar/1254008654156 
som neringslivet har bruk for framover. ${ }^{9}$ Selv i forskerprosjekter der man ikke krever brukerfinansiering, skal tildelingen altså primært være knyttet til hva som er nyttig for næringslivet. Energibruk og samfunnsaksept knyttet til fornybar energi generelt er viktige referanser for mange aktører med høyst legitime interesser, ikke minst når det gjelder utbygging og transport av energi. I forbindelse med disse temaene er det mye viktig forskning som må utføres, og som kan være sentral for videre samfunnsutvikling. Gode prosjekter burde ha et selvsagt krav på støtte, selv om de ikke gir kompetanseoppbygging for næringslivet, men tvert imot styrker grunnlaget for kritikk og motstand mot statens og næringslivets framferd på energiområdet.

Vi argumenterer for at ganske implisitte styringspremisser i ulike forskningsprogrammer skaper føringer som hindrer fri, kritisk forskning som samfunnet, i alt sitt mangfold, absolutt har nytte av. Forskning som stiller andre spørsmål, ville frambrakt kunnskap som er særdeles nyttig dersom utfordringen er å berge planeten, styrke lokaldemokratiet, øke politisk deltakelse, redusere fremmedgjøring samt forhindre sosial og økologisk fragmentering.

Programmer som man skulle tro har en mindre næringsorientert innretning, vris også i retning av innovasjon og næringsutvikling. Fra programmet Bedre helse og livskvalitet, under overskriften «Mål for programmet», heter det:

Hovedmålet for Bedre helse og livskvalitet (BEDREHELSE) er å fremme forskning og forskningsbasert innovasjon av høy kvalitet og nytteverdi som kan bidra til bedre folkehelse, økt livskvalitet og redusert sosial ulikhet i helse. Programmet ønsker å bidra til innovasjon og legge til rette for næringsutvikling på folkehelseområdet..$^{10}$

Innovasjon i betydningen nytenkning er jo bra, men i denne sammenhengen (og mange andre) er det åpenbart at det ofte betyr lønnsom nytenkning. Mange vil si at det også er bra, men en verdinøytral, apolitisk målsetting er det ikke. Det burde i større grad være rom for forskning

9 For flere detaljer: http://www.forskningsradet.no/prognett-energix/Forside/1253980140037
10 http://www.forskningsradet.no/no/Utlysning/BEDREHELSE/1254024735983 
som stiller seg åpent kritisk til næringsaktørers virksomhet på folkehelseområdet. Hvem vet om ikke folkehelsa hadde blitt bedre med mindre og ikke mer kommersialisering? Hvis vi ikke undersøker det, får vi heller aldri vite.

Selv om vi mener det skal være solid rom for forskning som søker svar ingen har spurt etter (den typiske grunnforskningen), er altså hovedpoenget vårt et annet: Vi må legge til rette for forskning som samfunnet trenger, og det er ikke alltid det samme som næringslivet og departementene etterspør. Men skal dette skje, må de som verken kan finansiere forskning selv eller påvirke Forskingsrådets prioriteringer i vesentlig grad, også ha en reell mulighet til å få svar på sine spørsmål på samme måte som mer innflytelsesrike samfunnsaktører har i dag.

Vi har sett at det innenfor tydelig næringsrettet forskning som EnergiX er klare føringer som tilgodeser økonomiske interesser, men det gjelder også et program som BEDREHELSE. Et program man kunne tenke seg snarere ville invitere til mer bredde i forskningen, er SAMKUL (Samfunnsutviklingens kulturelle forutsetninger). Dette er et relativt stort forskningsprogram i NFR som særlig retter seg mot humaniora og samfunnsvitenskap. Utgangspunktet er at «samfunnsutviklingen preges av globale endringsprosesser, for eksempel når det gjelder teknologi, demografi, kultur og miljø».

SAMKUL har finansiert svært mangfoldig forskning, også forskning som stiller spørsmålstegn ved forutsetninger som ligger i programmets egen plan. Men likevel er det et viktig signal om prioriteringer når også planen til dette forskningsprogrammet er rik på slike forutsetninger, og vi skal se nærmere på noen av dem.

Hva samfunnsutviklingens kulturelle forutsetninger betyr, og hvilken forståelse av forholdet mellom kultur og samfunnsutvikling dette avspeiler, er uklart - til tross for at denne frasen er et bærende element i programteksten. Både denne formuleringen og en god del av teksten ellers gir inntrykk av at man i hvert fall ikke har en forståelse av at det er samfunnsutviklingen som gir seg kulturelle uttrykk. En marxistisk orientert kulturforsker ville neppe nøle med å betegne programplanens kulturforståelse som borgerlig, eller kanskje hegeliansk. En slik kulturforståelse kan man være tilhenger av, men den er selvsagt ikke politisk nøytral eller naturgitt. 
I planen snakkes det mye om at utfordringer skal møtes. Hva slags utfordringer dette er, sies det imidlertid lite konkret om. Men teksten skaper et inntrykk av at et i utgangspunktet godt samfunn står overfor trusler, der kulturforskning på en eller annen måte kan være til hjelp for å bevare kvaliteter: «En annen viktig bakgrunn for SAMKUL var Humaniorastrategien fra 2008, som blant annet pekte på en humanistisk kunnskapsbase som en viktig beredskap i møte med store samfunnsendringer. $\rangle^{11}$ Og videre: «Forskningen skal styrke og utvide kunnskapsgrunnlaget for å gjøre samfunnet bedre rustet til å møte store utfordringer.» Samfunnsendringene skal på en eller annen måte takles. Men her synes det ikke som om de kulturelle «forutsetningene» er en drivkraft, men snarere en del av en verktøykasse som skal brukes for å håndtere endringer som har sin opprinnelse utenfor kulturen.

Man ser åpenbart ikke for seg at forskningen selv skal bidra til samfunnsendringer. Den skal nemlig primært være nyttig for myndigheter og de som driver med «innovasjon» (som må forstås som en økonomisk aktivitet, siden en utvidet betydning av ordet ikke presenteres). Forfatterne uttrykker konvensjonelle nyttebetraktninger også for SAMKUL. Samfinansiering og annen koordinering med EUs rammeprogram (som nå er Horizon 2020) framheves. Og innretningen på Horizon 2020 har vi allerede omtalt. Om menneske og natur skriver man:

For å forstå de kulturelle forutsetningene for endringene i vårt forhold til natur i bred forstand er det behov for forskning om den kulturelle betydningen av langsiktige menneskeskapte endringer kloden gjennomgår, de historiske betingelsene for veivalg knyttet til utnyttelse av naturen, og om de moralske spørsmålene ulike veivalg reiser. Dette gjelder blant annet «det grønne skiftet».

Valget av ordet «moralsk» i stedet for «politisk» kan ikke være tilfeldig. Hva om det er slik at samfunnsutviklingen ikke drives fram av «moralske veivalg», og slett ikke i deregulerte, liberale markedsøkonomier (hvem er det som tar de moralske valgene på samfunnets vegne der?), men av kamp mellom ulike interesser? Hvis referansen til moralsk er tilfeldig, er det nesten verre. Det viser i så fall et lite reflektert forhold til drivkrefter

11 http://www.forskningsradet.no/prognett-samkul/Sentrale_dokumenter/1253964329643 
i samfunnsutviklingen - og ikke minst til makt. $\AA$ (implisitt) avvise et slikt perspektiv legger faktisk politiske føringer for forskningen. Det er illustrerende at ordet «makt» bare nevnes to ganger i en tekst på 25 sider, og da i oppramsinger av stikkord for svært ulike forskningstemaer. Makt har tilsynelatende begrenset plass i samfunnsanalysen som ligger til grunn for programplanen. I planen kan vi videre lese:

De økonomiske aspektene ved samfunnsutviklingen handler om endringer i produksjon, distribusjon og forbruk av varer og tjenester og om former for økonomisk verdsetting. I kjølvannet av kriser i internasjonal økonomi de siste tiårene, har økonomer og kulturforskere pekt på behovene for en bedre forståelse av de kulturelle forutsetningene for den økonomiske utviklingen. Det handler blant annet om rollen til tillit i markedene, de kulturelle forutsetningene for korrupsjon og annen samfunnsskadelig økonomisk atferd, betydningen av rettferdighetshensyn i økonomiske beslutninger, hvordan folk forstår økonomiske sammenhenger, og rollen til myter og fortellinger om verdiskaping og rikdom.

Dette inviterer ikke til forskning som f.eks. stiller spørsmål ved grunnleggende trekk ved kapitalismen, noe man kan hevde det er god grunn til når det gjelder nettopp de temaene som ellers listes opp her. Mener man at «tillit i markedene» er et udiskutabelt gode, og at manglende tillit gjør markedene dysfunksjonelle? At selve markedene kan være problemet, åpnes det ikke for.

Selv om vi mener at det er noe som skurrer i selve innretningen på SAMKUL-programmet, mener vi ikke at problemstillingene som listes opp, er uviktige. Langt ifra. Problemet oppstår fordi programmet synes å ha adoptert en bestemt type snevre nyttebetraktninger og lar vore $\stackrel{a}{\circ}$ framheve andre og - etter vår oppfatning - mer fundamentale kultur- og samfunnsspørsmål.

\section{Konklusjon}

Fiskeriminister Sandberg ville følge forskerne helt inn på kontorene. Han sa det høyt og møtte motstand. Kravet om forskning for å nå politiske mål ble med rette oppfattet som et angrep på forskningens frihet, og 
dermed også et forsøk på å parkere forskning som stiller seg kritisk til sider ved oppdrettsnæringen. Her har vi forsøkt å vise at den innflytelsen Sandberg mislyktes i å skaffe seg med sine usminkede utspill, likevel kan oppnås, men på mer subtile måter som leder til langt mindre diskusjon. Det har vi gjort ved å peke på at forskningsprogrammer ofte bygger på implisitte politiske fundament. Til en viss grad er dette uunngåelig. Vi forstår at forskningsprogrammer må definere målsettinger og avgrense temaer, og at dette utelukker eller reduserer sannsynligheten for at prosjekter som ikke oppfyller målene, får finansiering. Problemet oppstår fordi systemet for forskningsfinansiering i dag framstår som et verktøy for å nå mål som ligner de Sandberg uttrykte. Det kan på samme måte ekskludere forskning som er viktig og særdeles samfunnsnyttig.

Fri og uavhengig forskning er en avgjørende kilde til kunnskap, og den kan representere et kritisk korrektiv til en samfunnsutvikling som ganske riktig gir mange utfordringer. Men det virker ikke som om NFR, og heller ikke EU, gjennom sine programmer ivaretar denne gamle og fundamentale innsikten. Dermed står vi i en situasjon hvor forskning som sentralt demokratisk verktøy står i fare for å plasseres på sidelinja. Hvis man erkjenner at kritikk er viktig og nyttig, og at samfunnsinteresser omfatter mer enn myndigheter og næringsliv, bør man ikke bare diskutere formuleringer i programplaner som kan være fulle av gode hensikter. Man bør også spørre hvordan man kan lage systemer som sikrer kritisk og uavhengig forskning, gjerne med et krav om nytteverdi på bestemte områder, men da i en sterkt utvidet forstand.

Vi mener ikke at det er galt å finansiere utviklingen av nye tekniske løsninger som gjør elektrisitetsproduksjon mer miljøvennlig, eller å finansiere planer for å få folk til å endre adferd som skal dempe effektene av klimaendringer. Problemet oppstår når denne forskningen fortrenger annen relevant forskning, og saerlig når premissene for Forskningsrådets og EUs prioriteringer ikke gjøres eksplisitte. Da blir det vanskelig å åpne for en viktig debatt. En slik debatt vil ha stor betydning fordi premissene som preger hva slags forskning vi konkret kan få finansiert over offentlige budsjetter, forskning som burde tilgodese alle samfunnsgagnlige formål, i sitt vesen er politiske. De legger nemlig bestemte syn og prioriteringer til grunn, men de svarer ikke på det fulle kunnskapsbehovet vi har for å 
sikre en helhetlig bærekraftig utvikling som forener økonomiske, sosiale og miljømessige hensyn både for oss og for kommende generasjoner.

\section{Referanser}

European Commission (udatert). Climate action, environment, resource efficiency and raw materials. Hentet 11.02.2018 fra https://ec.europa.eu/programmes/ horizon2020/en/h2020-section/climate-action-environment-resource-efficiencyand-raw-materials

European Commission (udatert). What is Horizon 2020? Hentet 11.02.2018 fra https://ec.europa.eu/programmes/horizon2020/en/what-horizon-2020

Forskningsrådet $(2015,18$. mai). Ny hovedstrategi er klar. Hentet 11.02.2018 fra https://www.forskningsradet.no/

Forskningsrådet (udatert). Inntil 100 millioner kroner til forskning for bedre folkehelse. Hentet 11.02.2018 fra https://www.forskningsradet.no/no/Utlysning/ BEDREHELSE/1254024735983

Forskningsrådet (udatert). Samfunnsutviklingens kulturelle forutsetninger (SAMKUL) - Sentrale dokumenter. Hentet 11.02.2018 fra http://www.forskningsradet.no/ prognett-samkul/Sentrale_dokumenter/1253964329643

Forskningsrådet (udatert). Stort program energi (ENERGIX). Hentet 11.02.2018 fra http://www.forskningsradet.no/prognett-energix/Forside/125398014003

Kristiansen, B.S. (2016, 10. mars). Per Sandberg advarte mot «mørke motkrefter» skapte storm. Aftenposten. Hentet 11.02.2018 fra http://www.aftenposten.no/

Kristiansen, B.S. (2016, 19. februar). Varsler oppgjør med «mørke motkrefter». Aftenposten. Hentet 11.02.2018 fra http://www.aftenposten.no/

Kvile, K. (2016, 24. februar) Frode Reppe mener forskere kan kjøpes. Fiskeribladet. Hentet 11.02.2018 fra https://fiskeribladet.no/

Meld. St. 7 (2014-2015). Langtidsplan for forskning og høyere utdanning 2015-2024. Stortinget. Saker og publikasjoner. Hentet 11.02.2018 fra: https://www.stortinget. no/no/Saker-og-publikasjoner/Saker

Myklebust, N. (2015, 16. juni). Usaklige beskyldninger fra Norske Sjømatbedrifters Landsforening (NSL). NINA. Aktuelt / Nyhetsartikkel. Hentet 11.02.2018 fra http:// www.nina.no/ 



\title{
KAPITTEL 5
}

\section{Kunnskapsbasert forvaltning og dilemmaer knyttet til usikkerhet}

\section{Maiken Bjørkan}

Seniorforsker, Nordlandsforskning

Kjellrun Hiis Hauge

Forskningsprogramleder, Høgskulen på Vestlandet

\begin{abstract}
Major value conflicts have been played out in the media about farmed salmon in Norway. One of the main controversies is whether salmon lice from aquaculture pens significantly affect the survival of wild salmon at stock level. Research related to this topic, which is key to knowledge-based management of aquaculture in Norway, has been criticized. The quality of this research has been claimed to be low and not applicable, and even claims of misconduct have been expressed. Besides conflicting interests, we argue that uncertainty is the core of the controversy. In this chapter we look at statements in selected texts from articles, reports and the media which can be linked to uncertainty and quality in research related to the effects of salmon lice. We discuss these statements in terms of qualitative aspects of uncertainty in knowledge. Further, we discuss the roles of these uncertainties in terms of selected principles within research ethics: in communication of uncertainty, the precautionary principle and quality of research.
\end{abstract}

Keywords: aquaculture, controversies, knowledge-based management, salmon lice, value conflicts, uncertainty

\section{Introduksjon}

Kunnskapsbasert forvaltning er et sentralt prinsipp i norsk forvaltning, og forskningen får en stadig viktigere rolle som premissleverandør for viktige samfunnsspørsmål og politiske beslutninger (se Ingierd, 2015). Ønsket er at politiske beslutninger skal være basert på sikker kunnskap, ofte referert

Sitering av dette kapitlet: Bjørkan, M., \& Hauge, K.H. (2019). Kunnskapsbasert forvaltning og dilemmaer knyttet til usikkerhet. I H. Ingierd, I. Bay-Larsen \& K. Hiis Hauge (Red.), Interessekonflikter i forskning (s. 107-129). Oslo: Cappelen Damm Akademisk. https://doi.org/10.23865/noasp.63.ch5 Lisens: CC BY 4.0 
til som fakta. Samtidig vil forskning på komplekse problemstillinger alltid være beheftet med usikkerhet. Innenfor tradisjonell akademia er usikkerhet et gode som inspirerer forskere til å jakte på kunnskap og få bukt med usikkerheten. Innen anvendt forskning, derimot, kan problemstillingene være akutte, komplekse og kontroversielle, slik at usikkerheten ikke lar seg fjerne (Funtowicz \& Ravetz, 1993). Som forskningssjefen ved Norsk institutt for naturforskning (NINA) sa: «En som jobber med ren forskning kan selvfølgelig ha som ambisjon å finne frem til det perfekte svaret. Men vi som jobber med å gi råd til forvaltningen, skal finne de best mulige svarene basert på akkumulert kunnskap» (Kjetil Hindar, til Dagens Noeringsliv 2011, vår utheving). Usikkerhet gjør at ulike tolkninger av kunnskapen kan forsvares. Hvordan usikkerhet er tatt høyde for i en politisk beslutning, kan være gunstig for én interessegruppe og ugunstig for en annen. Usikker kunnskap kan derfor fort bli politisert. Dette gjelder også forskningsfeltet som bygger opp under forvaltningen av havbruk. I Norge har den offentlige debatten om lakselus inneholdt kraftfulle bilder og narrativer om hvordan fjordene våre er ødelagt av oppdrettsnæringa. For denne næringa og tilhørende myndigheter er det imidlertid et mål å øke produksjonen. En femdobling av oppdrett er et uttalt mål fra regjeringen (Olafsen mfl., 2012). Partene står ofte steilt mot hverandre i verdisynet på laksefiskoppdrett og miljø, og er uenige om hvordan kunnskap skal tolkes og brukes. Dette er en utfordrende situasjon for forskere som skal gi best mulige råd til forvaltningen, basert på akkumulert kunnskap.

Konflikten i oppdrettskonteksten toppet seg våren 2016 da Norske Sjømatbedrifters Landsforening beskyldte forskerne for juks, og forskerne ved NINA truet med rettslige skritt for å stanse det de mente var sjikane (Tollesrud \& Dreyer, 2016). For eksempel har Norske Sjømatbedrifters Landsforening gjennom sine advokater krevd innsyn i tusenvis av dokumenter. Det dreier seg om alt fra eldre forskningsresultater og tillatelser til e-poster og SMS-er, helt tilbake til 1973. Både NINA og Havforskningsinstituttet har uttrykt bekymring i media for hvordan det som kalles en «kunnskapskrig», påvirker forskningen på både personnivå og samfunnsnivå. På personnivå pekes det på at situasjonen påvirker motivasjonen og måten forskerne kommuniserer med samfunnet på, siden de ikke bare kan formidle resultater, men må bruke tid på å forsvare 
seg selv: «(...) når dette pågår over så lang tid og i et slikt omfang, gjør det noe med forskerne. Jeg frykter at de blir defensive og ikke tør å være aktive formidlere» (Tollesrud \& Dreyer, 2016). Dette igjen kan ha innvirkning på rekrutteringen av forskere som skal gi svar på viktige samfunnsspørsmål. Den mest alvorlige konsekvensen, ifølge Havforskningsinstituttet, er at samfunnet går glipp av viktig kunnskap. Det pekes også på at «kunnskapskrigen» blir en barriere for ønsket vekst: «Det er spesielt at næringen vender seg mot forskningen (...). Regjering og storting har bestemt at videre vekst skal skje på en bærekraftig måte, og for å finne den grensen, trenger vi forskning» (Tollesrud \& Dreyer, 2016).

Interessekonfliktene knyttet til oppdrett er store, og hvordan kunnskap og usikkerhet blir tatt til inntekt for ulike verdisyn, kan få store konsekvenser for miljø, næring og samfunn. Forskningsetiske retningslinjer for naturvitenskap og teknologi (NENT, 2016) fremhever flere perspektiver som er svært aktuelle for interessekonflikten: føre var-prinsippet, formidling av usikkerhet og kvalitet i forskning. I dette kapitlet diskuterer vi utvalgte konflikter i lakselusdebatten i et forskningsetisk perspektiv. Vi er særlig interessert i hvordan uttalte konflikter i media og i rapporter kan knyttes til usikkerhet i et føre-var-perspektiv og til kvalitet i forskning. Vi kategoriserer usikkerhet i kunnskap i henhold til om den er reduserbar, og om usikkerheten kan forstås som uvitenhet, slik at den ikke kan fullt ut representeres ved statistiske metoder. Usikkerhet kan ha betydning for hvordan kvalitet i kunnskap kan forstås i sterke interessekonflikter.

Vi tar en kort gjennomgang av lakselusas rolle i forvaltningen av oppdrettsnæringa før vi går gjennom det teoretiske grunnlaget for kapitlet. Deretter analyserer og diskuterer vi utvalgte utsagn i media og rapporter i henhold til hvordan usikkerhet og kvalitet uttrykkes og kan forstås. Til slutt diskuterer vi dette i lys av utvalgte forskningsetiske retningslinjer.

\section{Lakselusa og trafikklyssystemet}

Det finnes både vilje og evne til vekst i oppdrettsnæringa og i regjeringen, samtidig som det er en bevissthet fra regjeringens side om at veksten må være bærekraftig. Mange hevder at dette ikke er mulig før problemer som lakselus og rømming er under kontroll. Også næringsaktørene er 
uenige seg imellom om vekst- og bærekraftspørsmål (Aarre, 2017; Hersoug \& Johnsen, 2012). Lakselusa er det største hinderet for vekst i oppdrettsnæringa, siden forskere betrakter lusa som en av de største truslene for villaks i sjøfasen (Svåsand mfl., 2017). Smitte fra oppdrettsmerder er regnet som hovedkilde. Et forvaltningsmål er at parasitter, bakterier og virus fra oppdrett ikke skal ha effekt på bestandsnivå på villfisk, og dermed er det sentralt å holde tallet på lakselus på oppdrettsfisk nede (Svåsand mfl., 2017).

I 2017 ble et nytt system for rådgivning implementert for forvaltningen av produksjonsvekst innenfor havbruk, ofte referert til som «trafikklyssystemet» (Regjeringen, 2017). Dette formidler risiko for dødelighet på vill, utvandrende smolt (ung laksefisk) forårsaket av lakselus, i hovedsak fra oppdrettsanlegg. Det er verdt å merke seg at denne rådgivningen ikke omfatter betydningen av lakselus på hele laksefiskbestanden, men kun på utvandrende smolt. Dette er ikke fullt så komplekst å vurdere. Man antar likevel at dødeligheten forårsaket av lus har en betydning for hele bestanden, men at dette vil variere etter tid og sted.

Risiko er representert gjennom tre kategorier: lav, moderat og høy risiko. Nivået er definert som følger: Lav risiko innebærer at det er sannsynlig at under 10 prosent av den utvandrende populasjonen dør som følge av luseinfestasjon; moderat risiko omfatter 10-30 prosent, og høy risiko betyr over 30 prosent (Karlsen mfl., 2016). Dette vurderes i hovedsak ut fra (i) et overvåkningsprogram som registrerer antall lakselus på utvandrende unglaks, (ii) modeller som simulerer smittepress på smolt ut fra rapporterte luseverdier fra oppdrettsanlegg og hvordan disse fraktes med vannstrømmer, og (iii) påvirkninger av lakselus på smoltens sjanse for å overleve (Nilsen mfl., 2017a). Det er altså helt sentralt å vite hvor mye lakselus det finnes i oppdrettsanleggene langs vår langstrakte kyst. Trafikklyssystemet ble prøvekjørt våren 2017, og i juni var sju produksjonsområder grønne, fem var gule og ett var rødt (Se Tabell 1) (NFD, 2017). Dette kunne gi grunnlag for en mulig vekst i de grønne områdene i 2018 og en mulig reduksjon i det røde området i 2019 (Nilsen mfl., 2017a). Som tabellen viser, oppgis også en kvalitativ vurdering av usikkerhet knyttet til risikovurderingene. Trafikklyssystemet operasjonaliserer en føre var-tilnærming ved at fargen for hele produksjonsområdet blir bestemt 


\begin{tabular}{|l|l|l|l|}
\hline Produksjonsområde & $\begin{array}{l}\text { Ekspertgruppens } \\
\text { vurderinger av risiko }\end{array}$ & Usikkerhet & $\begin{array}{l}\text { Departementets } \\
\text { vurdering }\end{array}$ \\
\hline 1: Svenskegrensen til & Lav & Meget sikker & \\
\hline 2: Ryfylke & Moderat & Noe usikkerhet & \\
\hline 3: Karmøy til Sotra & Høy & Noe usikkerhet & \\
\hline 4: Nordhordland til Stadt & Moderat & Rel stor usikkerhet & $\begin{array}{l}\text { Store variasjoner } \\
\text { innad }\end{array}$ \\
\hline 5: Stadt till Hustadvika & Moderat & Noe usikkerhet & \\
\hline 6: Nordmøre till Sør-Trøndelag & Moderat & Rel stor usikkerhet & På grensen til rodt \\
\hline 7: Nord-Trøndelag med Bindal & Moderat & Noe usikkerhet & \\
\hline 8: Helgeland til Bodø & Lav & Lite usikkerhet & \\
\hline 9: Vestfjorden og Vesterålen & Lav & Lite usikkerhet & \\
\hline 10: Andøya till Loppa & Lav & Noe usikkerhet & På grensen til gult \\
\hline 11: Kvaløya til Loppa & Lav & Stor sikkerhet & \\
\hline 12: Vest-Finnmark & Lav & Lite usikkerhet & $\begin{array}{l}\text { Altaelva mod. } \\
\text { påvirket }\end{array}$ \\
\hline 13: Øst-Finnmark & & Stor sikkerhet & \\
\hline
\end{tabular}

Tabell 1. Fra NFDs nettsider: «I tabellen over er det trukket frem noen områder der departementet vurderer at selv små endringer kan medføre endringer i fargelegging. Dette gjelder spesielt for områdene 4, 6 og 10 og til dels område 12» (NFD, 2017).

av den elva med størst risiko for dødelighet som følge av lakselusinfestasjon blant utvandrende smolt (Nilsen mfl., 2017a).

Havforskningsinstituttet har ansvar for å «koordinere overvåkning, forskning og rådgivning vedrørende lakselusinfestasjon på vill laksefisk langs norskekysten» (Nilsen mfl., 2017: 5b). Dette er et oppdrag fra Mattilsynet (Nilsen mfl., 2017b). Havforskningsinstituttet, NINA og Veterinærinstituttet alle sentrale kunnskapsprodusenter for rådgivningen knyttet til oppdrettsnæringa.

\section{Teori og metode}

I studien vår tar vi for oss et utvalg av akademisk litteratur, rapporter, nettsider og medieoppslag for å finne kontroverser og eksempler på hvordan forskere og andre aktører håndterer usikkerhet. Usikkerhet står sentralt i dette kapitlet, og ett av premissene våre for forståelsen av kontroversene rundt lakselus er at det er knyttet usikkerhet til kunnskap om overvåkning og effekter av lakselus. Forskning kan på den måten produsere flere spørsmål enn svar - og føre til kontroverser i stedet for konsensus. 
Vi støtter oss til litteratur om postnormal vitenskap for å kategorisere og diskutere usikkerhet. «Normal» i ordet «postnormal» refererer til Kuhns begrep om «normal science», som betegner forskning som finner svar på begrensede problemstillinger, og der det er enighet om hva som bestemmer fakta og god metodikk (Funtowicz \& Ravetz, 1993). Slike paradigmer kan så forkastes og erstattes av et nytt paradigme. Filosofien om postnormal vitenskap (Funtowicz \& Ravetz, 1993) bryter imidlertid med denne tenkningen. Den sier at i konfliktfylte og komplekse samfunnsutfordringer der vitenskapelig kunnskap er usikker, må demokratiske tilnærminger til for å vurdere hvilken kunnskap som er relevant, og hvem som forvalter gyldigheten og relevansen av denne kunnskapen. Dette gir støtte til at forskere fra ulike disipliner, teknologiutviklere, lakseoppdrettere samt lokalbefolkningen kan ha relevant kunnskap og erfaring som kan være nyttig for reguleringen av lakselus.

Hvordan usikkerhet forstås, formidles og håndteres, er sentralt for god håndtering av slike komplekse problemer med motstridende interesser. Ofte ligger det en forventning om at forskning kan redusere eller fjerne usikkerhet, men kompleksiteten i tematikken kan gjøre dette umulig. Noen usikkerheter kan kontrolleres gjennom statistiske metoder, men ofte er kunnskapen om usikkerhet begrenset, slik at den kun kan beskrives kvalitativt. Det er flere måter å skille mellom ulike typer usikkerhet på (se for eksempel Funtowicz \& Ravetz, 1993; Strand \& Oughton, 2009). Når vi går inn i lakselusproblematikken, skiller vi mellom usikkerhet som kan kontrolleres gjennom kvantifisering, og usikkerhet som ikke kan kontrolleres, fordi det vil være knyttet mer eller mindre uvitenhet til kunnskapen. Dessuten skiller vi mellom reduserbar og ikke-reduserbar usikkerhet, fordi det sier noe om hvorvidt mer forskning kan fjerne usikkerhet og tvil - og dermed løse uenigheter. Usikkerhet som ikke er reduserbar, kan ofte ikke kontrolleres, men det er ikke nødvendigvis slik. Alle fire kombinasjoner er mulige.

Det er verdt å merke seg at også kvantifiserbar usikkerhet kan være gjenstand for konflikt. For eksempel kan beslutninger basert på kvantifiserbar risiko være konfliktfylte, fordi interessegrupper kan ha ulike preferanser for hvilken risiko man er villig til å ta. Usikkerhet som ikke kan kontrolleres, gjør premissene for risikoanalyser uklare - og kan 
slik være en ekstra kilde til konflikt. Særlig kan dette være aktuelt når usikkerheten ikke lar seg tilstrekkelig redusere med ny kunnskap. Så vil vi påpeke at det å vurdere usikkerhet, slik vi gjør i dette kapitlet, vil innebære et subjektivt element. Andre vil kunne vurdere usikkerheten annerledes.

Usikkerhet i kunnskap kan på flere vis knyttes til forskningsetikk. Det å formidle usikkerhet handler om redelighet og etterrettelighet i forskning, i tillegg til at det er nødvendig for å følge føre var-prinsippet. Usikkerhet kan også knyttes til kunnskapens kvalitet og relevans. Når usikkerhet og interessekonflikter er betydelige, kan andre kunnskapsformer og verdibetraktninger være relevante, slik at medvirkning kan øke kvaliteten på kunnskapen og beslutningsprosessen. Vi bruker retningslinjene til NENT (2016) når vi diskuterer disse forskningsetiske aspektene.

\section{Kunnskapsbasert forvaltning under angrep}

Rådgivende organer som Havforskningsinstituttet (HI), Norsk institutt for naturforskning (NINA) og Mattilsynet uttrykker at lakselus fra oppdrett og rømt oppdrettslaks er vesentlige trusler mot bestander av vill laksefisk i oppdrettsintensive områder (Svåsand mfl., 2017). Denne påstanden er ikke akseptert av alle, særlig ikke alle i oppdrettsnæringa. Samtidig er det uenighet innad i næringa (Aarre, 2017), og noen forskere stiller seg kritiske til påstanden (van Nes mfl., 2011). I det følgende vil vi ta for oss noen eksempler på hvordan oppdrettsnæringa og dens interesseorganisasjoner har utfordret forskningen og de rådgivende forskningsinstitusjonenes roller. Målet vårt er imidlertid ikke å finne ut hvem som har rett i konfliktene. Det mener vi kan fastslås kun til en viss grad. Vi er mer interessert $\mathrm{i}$ å diskutere konflikten ut fra et forskningsetisk perspektiv. Først presenterer vi utsagn som kan knyttes til oppfatninger om usikkerhet i kunnskapsgrunnlaget, og diskuterer disse med hensyn til kategorisering av usikkerhet. Vi ser på to sentrale premisser som ligger til grunn for trafikklyssystemet, nemlig spørsmålet om 1) lusa har påvirkning på bestandsnivå, og 2) hvor mange lus som vil utgjøre en smittefare for enkeltfisk. Deretter tar vi for oss utsagn om kvaliteten i den forskningen forvaltningen baseres på. 


\section{Usikkerhet i kunnskapsgrunnlaget}

Kompleksiteten i lakselusproblematikken og manglende kunnskap er påpekt fra flere hold. Forseth mfl. (2017) understreker at under laksens vandring mellom hav og elv, utsettes den for mange trusler som kan forklare nedgangen i bestanden. De nevner en rekke menneskeskapte faktorer som påvirker laksens overlevelse: vannkraftregulering, migrasjonsbarrierer, endring eller ødeleggelse av habitat, sykdommer, forurensing, overfiske, introduserte parasitter, klimaendringer, genetisk påvirkning fra rømt oppdrettslaks samt lakseluspress fra oppdrett. Norges forskningsråd (NFR, 2017) beskriver laksens overlevelse i havet som en «svart boks», og understreker behovet for mer kunnskap om komplekse utfordringer:

Tradisjonelt har det vært vanskelig å følge laksen i havet, fra den forlater elva som smolt, til den kommer tilbake som voksen, gytemoden fisk etter ett til tre år. I denne perioden møter den mange utfordringer, som ytre fiender, smittestoffer og lakselus. Men hvordan disse utfordringene påirker laksens dødelighet i havet og hvilke faktorer som er viktigst, vet vi lite om. (NFR 2017, i vedlagt møtereferat.)

Nettopp det å redegjøre for usikkerheter i ulike vurderinger var et av oppdragene ekspertgruppen fikk da den skulle utarbeide grunnlagsmaterialet for trafikklyssystemet 2017 (Nilsen mfl., 2017a). Sju av de 64 sidene i rapporten er viet slike redegjørelser. Her er noe av det som er beskrevet: usikkerhet knyttet til hvor mye en smolt faktisk tåler av luseinfestasjon, manglende kunnskap om vill laksefisk som smittekilde, usikkerhet i vurderinger av smittepress grunnet forenklede betraktninger på vannstrømmer samt vandringsmønster til laksefisken, sesong- og årsvariasjoner i utviklingen av lus og i smoltens vandringer som ikke er tatt særlig høyde for, usikkerhet knyttet til betydningen saltholdighet i vannet har for avlusing, usikre tellinger av lus i merd og utfordringer med å bestemme luseinfestasjon på utvandrende smolt. I tillegg påpeker rapporten at det er utfordrende å tallfeste betydningen luseinfestasjonen har for den totale populasjonen av laksefisk, siden det er mange faktorer som påvirker laksefisken mens den er ute i havet. Disse usikkerhetene er knyttet til tallfesting av effekter. Kunnskapen er likevel ansett som tilstrekkelig for å 
kunne vurdere risiko som grunnlag for vekst i de ulike produksjonsområdene (Nilsen mfl., 2017a). I det følgende presenterer vi hvordan usikkerhet er blitt forstått og diskutert av næringa og andre.

I 2011 fikk Nofima og NINA i oppdrag å gå systematisk gjennom forskningslitteraturen som forvaltningen av oppdrettslaks er basert på. Fiskeri- og havbruksnæringens forskingsfond ba dem om å vurdere om oppdrett var hovedårsak til nedgangen i villaksbestanden. NINA og Nofima er begge forskningsinstitusjoner som tar oppdrag knyttet til akvakultur. Nofima konkluderte med at det ikke er «tilfeller som dokumenterer at lakselus er hovedårsak til endring i bestandsstørrelse» (van Nes mfl., 2011), og NINA konkluderte med at det ikke finnes støtte i vitenskapelig litteratur for at "påvirkning fra lakseoppdrett (lakselus og/eller rømt oppdrettslaks) ikke kan være årsak til at laksebestandene har problemer i oppdrettsintensive områder» (Hindar, 2011). Det vil si at mens forskerne fra Nofima uttrykker at de ikke finner belegg for at oppdrett er hovedårsaken til nedgangen i villaksbestanden, benytter forskerne fra NINA et omvendt perspektiv, nemlig at man ikke kan se bort fra det. Rapportene konkluderer verken med at oppdrett er den viktigste årsaken eller med at oppdrett er ikke den viktigste årsaken, så konklusjonen er for så vidt den samme. Dette er et uttrykk for at usikkerheten delvis kan kategoriseres som uvitenhet, og dermed ikke kan kontrolleres med statistiske metoder. Rapportene vektlegger usikkerheten fra ulike perspektiv. Det vil si at de velger motsatt vinkling av konklusjonen.

Hordaland fylkeskommune ba senere om en utredning, blant annet for å kartlegge oppdrettsnæringas muligheter for vekst. I den bestilte rapporten står det: «Mykje tyder likevel på at dagens lusesituasjon ikkje gir grunnlag for produksjonsauke i planområdet før lusesituasjonen er meir under kontroll» (Møklebust, 2015: 5). Denne konklusjonen ble motsagt i en rapport bestilt av oppdrettere i Hardanger. Oppsummeringen av den sier at «Lakselus er ikke årsaken til at bestandene av villaks og sjøaure ble svekket i Hardanger» (Gjøvik, 2015). Mens rapporten fra Hordaland fylkeskommune bruker formuleringen «tyder på», som implisitt uttrykker usikkerhet, skriver Gjøvik «er», som uttrykker sikkerhet.

Skaala mfl. (2014) oppsummerer flere års undersøkelser på smolt som vender tilbake til Guddalselva. Blant annet konkluderer studien med at 
overlevelsesraten av merkede ørret som er behandlet med et avlusingsmiddel, er høyere enn hos de fiskene som ikke fikk det. Basert på dette og andre undersøkelser argumenterer forfatterne for at lakselus kan ha stor innvirkning på dødeligheten. Samtidig påpeker de en rekke andre faktorer som kan påvirke resultatene deres i både positiv og negativ retning. Oppdrettsavisa iLaks.no ${ }^{1}$ karakteriserer denne artikkelen som en «Verdiløs diskusjon av luspåvirkning», fordi den ikke tar for seg andre påvirkninger enn lus fra oppdrettsfisk (Berge, 2015).

Det kreves av forskere at de uttrykker usikkerhet ved å diskutere betingelser eller forhold som kan svekke funn og konklusjoner, slik Skaala og medforfatterne gjør. Det samme kreves kanskje ikke av andre aktører, en utfordring også Nelkin (1975) og Yearley (2005) peker på. Mens forskerne må grunngi sine påstander med data og teori, kan det for andre aktører være tilstrekkelig å stille spørsmål til funnene. Eksempler og utsagn som er presentert over, tyder på at det er uvitenhet knyttet til forhold som påvirker villaksens overlevelse på bestandsnivå, og hvor viktig smitte av lus fra oppdrettsfisk er. Ikke overraskende er det utfordrende å forklare i hvilken grad ulike faktorer påvirker villaksen. I slike tilfeller er statistiske metoder ikke tilstrekkelige for å beskrive usikkerheten, eller kontrollere den. Trolig vil forskningsprosjekter øke kunnskapen om ulike påvirkninger på villaksbestanden, men det er vanskelig å se for seg at alle forklaringsfaktorer blir avdekket og kvantifisert såpass tilfredsstillende at ulike interesseparter blir enige om alle «fakta». Kompleksiteten i økosystemenes sammenhenger blir for stor til å kunne redusere all usikkerhet.

Et premiss for forvaltningen er nettopp at villaksbestanden kan minke som følge av at villaksen svømmer forbi et luseinfisert anlegg. Gjøvik (2015) hevder at det ikke er noen sammenheng mellom antall luseegg i merdene og infestasjonsnivået på villfisk. Han peker på at regionale variasjoner er betydelige fordi smittefaren også er avhengig av lokale vannstrømmer, vanntemperatur og topografi. Også Nofima er kritisk og presenterer følgende innvending:

1 https://ilaks.no/bevisene-om-lakselusas-herjinger-som-ble-underkjent/ 
Basert på tilgjengelige fakta så kan vi ikke se at det foreligger noen vitenskapelig dokumentasjon på en enkel sammenheng mellom antall kjønnsmodne hunnlus, i det vesentlige et produkt av antall oppdrettslaks og antall hunnlus per fisk, og marin overlevelse av vill laksefisk, og at beregningen av bærekraftig nivå derfor ikke er tilstrekkelig kunnskapsbasert. (van Nes mfl., 2011: 3)

Nofima uttrykker at sammenhengen mellom antall lus og lusas påvirkning på vill laksefisk er så usikker at beslutningen om tillatt antall ikke vil være kunnskapsbasert.

I likhet med spørsmålet om lusas påvirkning på utvandrende smolt vil også spørsmålet om hvor mange lus som vil utgjøre en smittefare for enkeltfisk, være såpass komplekst at usikkerheten ikke kan kontrolleres, og at deler av den ikke er reduserbar. Et relevant spørsmål er hvordan man best håndterer denne usikkerheten.

\section{Fagfellevurdering og kvalitet i usikker kunnskap}

Fagfellevurdering er en ordning for å sikre kvalitet i forskningen. Med kritisk blikk skal teoretisk ståsted, problemstilling, metode, data, analyse og tolkning av resultater vurderes. Teksten skal tydeliggjøre og diskutere styrker og svakheter ved studier, inkludert usikkerhet. Fagfellevurderinger skal sikre at forskningen følger normer for kvalitet og er verdinøytral (se også Nybø mfl. i denne antologien). Selv om fagfellevurdering har autoritet blant forskere, har deler av næringa kritisert ordningen. Redaktøren i oppdrettsavisa iLaks.no har ved flere anledninger hevdet at deler av forskningen som støtter forvaltningen, er av dårlig kvalitet. For eksempel uttrykker han følgende om artikkelen til Skaala og medforfattere fra 2014: «Forfatterne diskuterer ingen andre påvirkninger enn lakselus, og selv dette gjøres på en forkastelig måte (...). Fagfellevurderingen har nok en gang spilt falitt» (Berge, 2015) ${ }^{2}$.

Kvalitet i forskning knyttes også til forskningen og forskerens rolle. I forbindelse med lakselusdebatten og at Havforskningsinstituttet protesterte mot NSLs krav om innsyn i e-poster, uttalte en stortingspolitiker følgende:

2 Berge og avisen iLaks.no er blitt kritisert for å fremstå «som et reklamebyrå for oppdrettslaks». Se: http://nordnorskdebatt.no/article/hva-driver-dere-aslak-berge-are 
Det er ikke unaturlig at jeg har en oppfatning av at forskningen i Guddalselva og trolig andre steder ikke har vært av en slik kvalitet at den kan benyttes i forvaltningen av næringen dersom vi ikke får gode svar på problemstillingene som NSL reiser. (...) Det minste vi må forvente, er at forskning er korrekt, uavhengig av politisk oppfatning. Og sist, men ikke minst, må forskningen være til å stole på. Dessverre ser det ikke ut til å være tilfellet når det gjelder forskningsinstitusjonene sine reaksjoner på ønske om innsyn i forskningen. (Trellevik, 2016, i Morgenbladet)

Stortingspolitikerens krav til kvalitet synes å være at forskningen skal gi korrekte svar på visse problemstillinger. Videre anklager han forskningen for ikke å være åpen eller politisk nøytral. Med begrensede muligheter til å redusere usikkerhet vil forskning aldri bli verdsatt, når kravet er at den skal være korrekt. Mer alvorlige er anklagene NINA og Havforskningsinstituttet i mange år har blitt utsatt for, nemlig at forskningen deres på lakselus er juks, og at forskerne er korrupte (Tollesrud \& Dreyer, 2016, se også Myklebust i denne antologien). Blant annet kommer iLaks.no's redaktør med følgende beskyldninger: «Det er neppe å gå for langt å antyde at elendighetsfortellingen har holdt liv i ganske mange forskere i ganske mange år» (Berge, 2016). Det antydes at forskerne har profesjonsinteresser i å produsere forskning som kan brukes kritisk overfor næringa. Havforskningen har sågar blitt beskyldt for selv å skade villaks av et oppdrettsselskap «som mener at Havforskningsinstituttets studier både kan ha skadet den ville bestanden i elven og gitt et falskt bilde av at lakselus fra oppdrett gir nedgang i villfisk» (NRK Hordaland, 2016).

Mens forskeres håndtering av usikkerhet kan styrke kvaliteten på og relevansen av forskningsbaserte råd, kan usikkerhet i kunnskap også misbrukes. Forskerne kan, vel vitende eller ikke, gi en begrenset fremstilling av usikkerhet, slik at rådet fremstår som mer sikkert. For eksempel kan teksten undergrave usikkerhet hvis den ikke diskuterer graden av uvitenhet, eller vurderinger om usikkerhet kan reduseres. Interesseparter kan på den annen side bruke usikkerhet og fremstillingen av usikkerhet som et argument for å underkjenne forskningen som utilstrekkelig, tendensiøs eller basert på juks (Gleick, 2007). Usikker forskning, særlig når det er knyttet uvitenhet til kunnskapen, muliggjør ulike tolkninger som kan støtte ulike interesser. Dermed skal det godt gjøres at kunnskap er 
verdinøytral når problemstillinger er komplekse - og noe av usikkerheten i kunnskapen ikke er kan kontrolleres eller ikke er reduserbar. Uten en betydelig bevissthet om usikkerhet og dens rolle, kan råd fremstå for noen som objektive og basert på gode fakta, mens de for andre kan fremstå som politiske innspill for å fremme egne interesser (MacDonald mfl., 2016).

\section{Forskningsetiske problemstillinger}

Lakselusdebatten er et eksempel på at spørsmålet om hva den beste kunnskapen er, ikke er selvsagt. Det store spørsmålet er knyttet til smitte av lakselus fra oppdrettsfisk til villfisk, og vi har argumentert for at det vil være begrenset hvor mye av denne usikkerheten som kan reduseres og kontrolleres. Det er betydelige interessekonflikter i denne problematikken, og aktører uttrykker stor uenighet om kunnskap og hvordan den skal tolkes og anvendes. Oppsummert hevder representanter for oppdrettsnæringa at oppdrett ikke har påvirkning på villaksbestander, og de hevder at forskere sier at «oppdrett er den viktigste grunnen til nedgangen i villfiskbestander». En del av forskningslitteraturen bruker heller formuleringer som at «oppdrett har sannsynligvis en effekt på villfiskbestander». Forskere uttrykker ofte usikkerhet gjennom forbehold og gjennom nedtoning av resultater.

Hvis forvaltningstiltak blir knyttet til antall tillatte lus i merd, blir det introdusert flere usikkerheter. I tillegg til usikkerheten om hvorvidt oppdrett er hovedgrunnen til nedgangen i villaksbestandene, kommer usikkerheten om hvilket antall lus som utgjør en fare for villaksen. Vi har argumentert for at usikkerhet forbundet med smittens påvirkning på villfiskbestanders dødelighet, samt antall lus fra oppdrettsanlegg som utgjør en trussel, delvis kan kategoriseres som uvitenhet. Kompleksiteten i økosystemet gjør at man ikke kan kvantifisere effekten av alle faktorer som påvirker en bestand. Denne uvitenheten kan ikke representeres tilstrekkelig av statistiske metoder, og dermed kan man ikke ha kontroll over den aktuelle usikkerheten. Mer forskning kan redusere noe av den, men det vil likevel finnes usikkerhet som ikke er reduserbar.

Videre har vi antydet hvordan forskere og næringa har ulik forståelse for hva kvalitet i forskning skal bestå av. Forskersamfunnet legger vekt 
på åpenhet om alle sider ved kunnskapsproduksjonen, inkludert usikkerhet og diskusjon om resultatenes gyldighet. Dette skal kvalitetssikres gjennom fagfellevurdering. Utsagnene vi har valgt ut, tyder på at brukere av denne forskningen forstår kvalitet som sikker og relevant kunnskap.

Nå vil vi diskutere disse aspektene i et forskningsetisk perspektiv, basert på et utvalg av NENTs retningslinjer. Rekkefølgen for de forskningsetiske områdene vi har valgt, er formidling av usikkerhet, føre var-prinsippet, kvalitet i forskning og medvirkning. Avslutningsvis reflekterer vi over mulige utsikter for forskningens status og rolle.

\section{Formidling av usikkerhet}

En av NENTs (2016) retningslinjer sier følgende: «Forskeren skal få klart fram usikkerhet $\mathrm{i}$ egen forskning og vurdere risiko som følge av forskningsfunn.» Usikkerhet er sentralt i forskningsetisk sammenheng fordi måten usikkerhet blir behandlet og formidlet på, kan påvirke hvordan relevansen av og kvaliteten på kunnskapen blir forstått. Trafikklyssystemet uttrykker usikkerhet både i form av en risikoanalyse og i form av en kvalitativ vurdering av hvorvidt risikoanalysen er usikker. I tillegg kommuniserer forskere usikkerhet gjennom diskusjoner om gyldighet av funn og konklusjoner i egen og andres forskning.

Ved å bruke usikkerhetskategorier inspirert av Funtowicz og Ravetz (1993), har vi vist at forskning på lakselus er preget av usikkerhet som ikke kan kvantifiseres eller reduseres. Det at trafikklyssystemet består av en kvalitativ vurdering av usikkerhet, er kanskje et tegn på at de som har utviklet det, kan være enige i dette. Kanskje kunne usikkerheten bli tydeligere om kilder til usikkerhet ble karakterisert i henhold til områder av uvitenhet og hvorvidt usikkerheten var reduserbar. På en annen side kan usikkerhet være utfordrende å forstå og forholde seg til. Nyansene i forskernes forbehold kan være vanskelig å få med seg. Kan det for eksempel være at mens forskningslitteraturen konkluderer med at lus har en påvirkning på villaks, forstår næringa dette som at litteraturen sier at lusa er den viktigste årsaken til bestandsnedgangen? At lusa har en påvirkning, kan være relevant, selv om andre faktorer kan være mer dominerende. Eksempler tidligere i kapitlet viser at små nyanser i 
hvordan usikkerhet ordlegges, kan gi ganske forskjellig inntrykk av hvilket standpunkt utsagnet støtter. Et felles begrepsapparat - altså hvordan man forstår usikkerhet - vil være én metode for å sørge for bedre kommunikasjon mellom de ulike aktørene. Det å skille mellom usikkerhet og uvitenhet, og å få klarlagt om usikkerhet er reduserbar eller ikke, kan være nyttige karakteristikker som både kan illustrere begrensninger ved kunnskap og invitere til diskusjoner om hvordan usikkerhetene bør håndteres. Det finnes en rekke forslag til hvordan kvalitative egenskaper ved usikkerhet kan kartlegges og formidles (se for eksempel Strand \& Oughton, 2009).

Usikkerhet kan også misbrukes bevisst i en interessekonflikt for å påvirke beslutninger i aktørenes favør. Gleick (2007) lister opp en rekke taktikker: hindre og undergrave god forskning, misbruke fakta og usikkerheter, misbruke en eksperts autoritet, tilsløre verdibaserte vurderinger i argumentasjon, appellere til følelser, gå til personangrep, mistolke et motargument med hensikt for så å motbevise det, anvende ugyldig generalisering og bruke forskning med forhåndsbestilte resultater. $\AA$ undergrave forskning ved å påpeke usikkerhet, og kanskje tolke den på andre måter, kan dermed bli et virkemiddel i konflikter. Kanskje mister forskningen sin autoritet. Et aspekt ved dette er at forskersamfunnet, og kanskje samfunnet for øvrig, forventer at en forsker ikke presenterer bastante konklusjoner, men reflekterer over styrker og svakheter. Blir det en ubalanse ved disse forventningene, når det er greit at andre aktører uttrykker rene påstander? Eller er forskeren allerede i en maktposisjon ved at forskningen hennes blir brukt av myndighetene, slik at kritikk av forskningen ved bastante påstander utjevner maktbalansen noe? Vi kjenner ikke intensjonen bak sitatene, om målet er å påvirke bevisst på en slik måte Gleick (2007) beskriver. Uansett viser dette en mangel på en omforent forståelse for hvordan man skal forholde seg til usikkerhet.

\section{Føre var-prinsippet som forskningsetisk prinsipp}

NENT definerer føre var-prinsippet som følger: «Når menneskelige aktiviteter kan føre til moralsk uakseptabel skade som er vitenskapelig rimelig, men usikker, skal man foreta handlinger for å unngå eller minske 
slik skade» (NENT, 2016: 12). I vårt kapittel er det død villaks på grunn av lus i oppdrettsanlegg som er den uakseptable skaden. I henhold til norske bestemmelser skal regulering av fiskeoppdrett følge føre var-prinsippet som et ledd i å oppnå bærekraftig utvikling (naturmangfoldloven, 2009). Prinsippet innebærer at usikkerhet i kunnskap skal komme miljøet - i vært tilfelle villaksen - til gode på bekostning av andre verdier. De forskningsetiske retningslinjene sier videre at de involverte forskerne skal «bestrebe seg på å bidra med kunnskap som er relevant for å følge føre var-prinsippet» (NENT, 2016: 12). Kunnskap om usikkerhet er absolutt relevant for prinsippet. Føre var-prinsippet sier ikke noe om hvordan det skal eller bør operasjonaliseres, hvor stor usikkerhet man kan tillate for å følge prinsippet, eller hvordan man skal vektlegge de motstridene verdiene som står på spill. Selv om føre var-prinsippet krever at det skal foreligge plausibel kunnskap, og at vurderingen av usikkerhet skal være vitenskapelig fundert, vil måten man skal ta hensyn til usikkerhet på, også være en politisk avveining. Derfor må forskeren samarbeide med relevante aktører i utarbeidelsen av hvordan prinsippet skal operasjonaliseres (NENT, 2016).

I postnormal vitenskap understrekes viktigheten av medvirkning $\mathrm{i}$ viktige samfunnsspørsmål med motstridende interesser og høy usikkerhet (Funtowicz \& Ravetz, 1993). Dette begrunnes med at verdier og fakta ofte er vevd sammen, at usikkerheten gjør at tolkningsrommet er stort, at vitenskapelige metoder gjerne ikke er tilstrekkelige for å løse problemet, og at det på grunn av interessekonflikter og usikker kunnskap ikke finnes noen «beste» løsning. Diskusjoner om valg i forskning og hvordan disse påvirker usikkerhet, kan være relevant i prosessen fra problemformulering til beslutning: Valg om hvilken kunnskap som trengs for å forstå eller håndtere et problem, valg av indikatorer, kartlegging av usikkerheter og håndtering av usikkerhet (Strand \& Oughton, 2009). Dette kan også være viktig for legitimiteten av resultatet og for opplevelsen av rettferdighet.

Føre var-prinsippet er innebygd i trafikklyssystemet ved at elva som er forbundet med størst risiko, representerer hele produksjonsområdet. Trafikklyssystemet inneholder også en kvalitativ beskrivelse av usikkerhetsnivået (se Tabell 1). Det kan selvsagt diskuteres om systemet formidler usikkerhet på en tilstrekkelig måte, om usikkerhet er tilstrekkelig tatt 
høyde for, eller om systemet legger opp til en altfor streng eller urettferdig regulering fordi premissene ikke er rimelig vitenskapelig begrunnet. Man kan forstå debatten som utspiller seg, som en uenighet mellom aktører om hvordan føre var-prinsippet bør operasjonaliseres. Forskerne fra de formelt rådgivende kunnskapsinstitusjonene mener kanskje at usikkerheten om påvirkningen fra rømt oppdrettsfisk og lus i oppdrettsanlegg på villaksbestanden er liten nok til å hindre produksjonsvekst for å ivareta villaksen. Aktører fra næringa, sammen med representanter fra oppdragsforskning, gir uttrykk for at usikkerheten rundt årsakssammenhengene er for stor til at det skal gå ut over næringa. Uenigheten handler da om det er vitenskapelig rimelig å anta at lakselus har en vesentlig effekt på bestandsnivået.

Kanskje diskusjonen heller burde ha vært om hvordan man skal ta høyde for usikkerheten? Paradoksalt nok kan man tenke seg at formidling av usikkerhet fører til at kunnskapen oppfattes som at den ikke er vitenskapelig rimelig for å igangsette tiltak. Ett spørsmål er hvordan forskerne kan formidle usikkerhet på en forståelig måte - uten å ofre legitimiteten til rådene. Utdragene vi har presentert, tyder på at det er behov for å unngå riktig-galt-dikotomien og forventningene om at kunnskapshull kan tettes. Der kan usikkerhetsbegrepene vi har brukt i analysen, være til hjelp. Et annet spørsmål er hvordan man kan balansere formidling av usikkerhet og formidling av kunnskap som vitenskapelig rimelig.

\section{Kvalitet og åpenhet i forskning}

NENT har to retningslinjer som er relevante for vår diskusjon av kvalitet i forskning: «Forskeren har ansvar for å utøve redelig, sannferdig og etterrettelig forskning av god kvalitet, og forskningsinstitusjonen skal tilrettelegge for slik praksis» (NENT, 2016: 9), og «Forskningsinstitusjonen og de involverte forskerne skal sikre åpenhet og vitenskapelig kvalitet $\mathrm{i}$ oppdragsforskning» (NENT, 2016: 16). NENT uttrykker at etterrettelighet og åpenhet er sentralt for å oppnå kvalitet og tillit i samfunnet.

Utdragene som er diskutert tidligere i kapitlet, viser at det er betydelig uenighet om hva som karakteriserer kvalitet i forskningen. Representanter fra oppdrettsnæringa synes å kreve at forskningen må være sikker for 
at den skal kunne anvendes, mens forskersamfunnet vektlegger styrker og svakheter når de sannsynliggjør konklusjoner. Videre er fagfellevurdering sentral for forskerne, mens brukerne er mer opptatt av forskningens relevans. Både åpenhet i forskning og verdinøytral forskning står sentralt for hvordan kvalitet i forskning fagfellevurderes. I forskersamfunnet omfatter åpenhet vanligvis det teoretiske grunnlaget, dataene, metoden, analysen og tolkningen. Åpenhet om habilitetsspørsmål er også forventet. Innsyn i e-poster, derimot, ligger langt utenfor hva som forstås som nødvendig for at forskningen er åpen.

Man kan ikke kreve at en forsker ikke skal ha politiske meninger angående saker hun forsker på. Kanskje kan personlige verdier komme frem på diskusjonsmøter eller i e-poster? Et annet spørsmål er hvordan egne verdier påvirker forskningen. Derfor skal det legges til rette for at alle steg i forskningen skal kunne vurderes kritisk (se også Nybø mfl., 2011). I fagfellevurderte tidsskrift skal vitenskapelige undersøkelser helst følge kjent og utprøvd metodikk. Metoder for enkle forsøk der man kan kontrollere variabler i et laboratorium, kan gi sikre resultater, mens kravet om utprøvd metodikk på undersøkelser av økosystemer kan være utfordrende. Det betyr ikke at man skal unngå slik forskning, men kvalitet må kanskje forstås som noe annet enn «sikkert». Kan hende er forventningene til kunnskapsbasert forvaltning basert på fagfellevurdert forskning altfor høye. I forskning på saker forbundet med motstridende interesser kan kvalitet også forstås som relevans, slik at forskningsspørsmål, metode og nyanser i diskusjonen vurderes ut fra samfunnsproblemet. Det innebærer mindre grad av verdinøytralitet.

Når kunnskapsgrunnlaget for en beslutning er usikkert, trenger ikke kunnskapen å være av dårlig kvalitet. Hvis usikkerheten ikke er reduserbar fordi kompleksiteten er for stor, hvis forskningen vil ta for lang tid eller er for ressurskrevende, kan kvalitet også knyttes til gode måter å formidle og håndtere usikkerhet på, og til åpenhet. Man må heller finne ut hvordan man kan ta høyde for usikkerheten og få til konstruktiv medvirkning. Kvalitet i forskningsbaserte råd må også knyttes til kunnskapens relevans og til relevansen av håndteringen av usikkerhet. Å formidle usikkerhet på nye måter og diskutere hvordan forenklinger og valg i forskningsprosessen kan påvirke resultatene, kan gjøre de vitenskapelige rådene mer 
verdinøytrale. Føre var-prinsippet er en måte å håndtere usikkerhet på, men kvaliteten på hvordan dette er operasjonalisert, er avhengig av formidlingen av usikkerhet.

Det finnes en lang tradisjon for fagfellevurdering, men tradisjonen for å gi opplæring i hvordan forskere skal samhandle med andre personer enn forskere, er heller svak. MacDonald mfl. (2016) anbefaler at forskere som jobber innen anvendt forskning, får nødvendig opplæring. Det vil si trening i å være mer oppmerksom på påvirkning av verdisyn - både hos seg selv og fra andre aktører, hvordan man kan kommunisere med offentligheten med hensyn til teknisk vanskelig informasjon, hva usikkerhet er i ulike kontekster, hva risiko innebærer, og hva kunnskapsbaserte råd kan være (eller ikke være). For eksempel kunne det være interessant å se om det vil hjelpe at brukere, interessegrupper, forvaltere og beslutningstakere gjøres oppmerksomme på at de ikke alltid kan forvente entydige og dermed verdinøytrale forskningsresultater i lakselusdebatten.

\section{Avsluttende refleksjon: Konstruktiv usikkerhet?}

I forvaltningen av fiskeoppdrett og våre kystområder er kunnskap et sentralt prinsipp der forskning blir brukt til å legitimere politiske avgjørelser. I tillegg til å skulle beskytte villaksen er forvaltningen basert på politiske, sosiale og økonomiske avveininger. «Den beste og mest relevante kunnskapen» som skal støtte opp om forvaltningen, har vært gjenstand for heftig debatt og har vært med å skape - heller enn å løse - konflikter i lakselusproblematikken. I lys av denne «kunnskapskrigen» kan det være bedre for forskningens legitimitet å bruke begrepet «evidence-informed» fremfor «evidence-based» (MacDonald mfl., 2016). Muligens er «kunnskapsinformert» et kronglete begrep på norsk, men det kan markere at verdi- og politikkaspektet i forvaltningen har sin rettmessige plass. Kanskje fremstår forskningen i dag som hovedgrunnlaget for beslutninger, og blir dermed gjenstand for i overkant mye kritikk og sjikane. Vi foreslår at usikkerhet bør betraktes som verdifull kunnskap, og hvordan man håndterer usikkerhet i beslutningsprosesser, kan være mer sentralt i debatten. Dessuten er det vesentlig at forskere, næring og forvaltning utvikler et felles begrepsapparat. 
Føre var-prinsippet er verdibasert fordi det innebærer en risikovurdering som verdsetter natur, men medvirkning kan bidra til en annen vektlegging av verdiene som står på spill. I tillegg er det viktig med kritiske innspill for å fremme god forskning, og kritikk og innspill fra interesseparter kan sees på som nyttig «motekspertise» (van der Sluijs, 2012).

Oppdretterne har ansvaret for å telle lus på fisk i merd regelmessig. De kommer med innspill til høringer, driver lobbyvirksomhet, engasjerer advokater i møte med forskere og kommer med flammende innlegg i media. Konfliktnivået er likevel høyt, og næringa er ikke enig innad. Dette kan være et tegn på manglende medvirkning, noe som imidlertid kan løses på flere måter. Det kan åpnes opp for økt medvirkning, eller for at rammene for medvirkning endres (for eksempel når og hvor andre aktører får delta i rådgivningsprosessen). Videre vil et felles begrepsapparat være et tiltak som kan bidra til bedre kommunikasjon. Konflikten utspilles ved at næringa peker på feil i forskningen, mens disse «feilene» betraktes som usikkerhet i akademia. Kjernen i konflikten er verdiene som står på spill, mens eksemplene i kapitlet vårt tyder på at forskningens kvalitet blir gjort til stridens kjerne. Kanskje kan verdier og usikkerhet løftes frem i medvirkende prosesser, i tråd med hva Wynne (2007), van der Sluijs (2012) og Funtowicz og Ravetz (1993) argumenterer for. Her kan føre var-prinsippet være et utgangspunkt sammen med en diskusjon om hvordan trafikklyssystemet tar høyde for usikkerhet og verdigrunnlag.

Det er selvsagt ikke bare oppdrettere som er brukere av kunnskapen, men også lokalbefolkningen, naturvernorganisasjoner mfl. Disse er også sentrale for å vurdere verdier som er verdt å kjempe for, og for å vurdere kvalitet i forskning og forvaltning. Kanskje vil vitenskapelige råd oppfattes som mer relevante og legitime. Samtidig kan uenighetene være så grunnleggende at konsensus er umulig å oppnå. Maktfordelingen blant interessepartene er et sentralt tema som vi ikke har diskutert i dette kapitlet, men som må håndteres i slike interessekonflikter.

Kan vi så forklare kunnskapskrigen som et resultat av at vitenskapen som skal støtte forvaltningen, er en såkalt «science in the making» (Latour, 1987)? Kanskje bør vitenskapen forstås som en prosess der utvikling av nye metoder og mer kunnskap kan modne den vitenskapelige tilnærmingen og dernest sikre legitimitet? En postnormal tilnærming vil 
heller tilsi at med såpass store interessekonflikter og uvitenhet om våre økosystemer, vil oppfatningen av kvalitet i forskning være mer fleksibel og avhengig av medvirkning og interessepartenes oppfatning av usikkerhet, verdier og risiko. Samtidig er usikkerheten utfordrende å forholde seg til og krever mye av både brukere og forskere. Vi har pekt på at det kan være en ubalanse i kravene som stilles, og at alle aktører bør bidra i diskusjonen om hvordan man skal håndtere usikkerhet.

\section{Referanser}

Aarre, E. (2017, 7. mai). Miljøproblemer hindrer vekst i oppdrettsnæringen. Aftenposten.

Berge, A. (2015). Bevisene om lakselusas herjinger som ble underkjent. iLaks.no. https://ilaks.no/bevisene-om-lakselusas-herjinger-som-ble-underkjent/

Berge, A. (2016). HIs kamp mot oppdrettsnæringen. iLaks.no. https://ilaks.no/ his-kamp-mot-oppdrettsnaeringen/

Dagens Næringsliv (2011, 11. juni). Eksperter krangler om laks og lus. https://www. dn.no/nyheter/naringsliv/2011/o7/11/eksperter-krangler-om-lus-og-laks

Forseth, T., Barlup, B.T., Finstad, B., Fiske, P., Gjøsæter, H., Falkegård, M., Hindar, A., Mo, T.A., Rikardsen, A., Thorstad, E., Vøllestad, L.A., \& Wennevik, V. (2017). The major threats to atlantic salmon in Norway. ICES Journal of Marine Science.

Funtowicz, S.O., \& Ravetz, J.R. (1993). Science for the post-normal age. Futures, 25(7), 739-755. doi:http://dx.doi.org/10.1016/0016-3287(93)90022-L

Gjøvik, J.O. (2015). Lakselus og rømt oppdrettslaks bør ikke begrense produksjonen av oppdrettslaks i Hardanger: Innspill til Regional Kystsoneplan for Sunnhordaland og Ytre Hardanger. Hentet fra https://www.aquablogg.no/lakselus-ogromt-oppdrettslaks-bor-ikke-begrense-produksjonen-av-oppdrettslaks-ihardanger-2015/

Gleick, P.H. (2007). Testimony to the Senate Committee on Commerce, Science, and Transportation. For the Hearing on Climate Change Research and Scientific Integrity. Threats to the Integrity of Science. Committee on Commerce, Science, and Transportation. http://pacinst.org/wp-content/uploads/2007/o2/Gleick_ Senate_Commerce_2-7-07.pdf.

Hersoug, B., \& Johnsen, J.P. (2012). Kampen om plass på kysten - interesser og utviklingstrekk $i$ kystsoneplanleggingen. Oslo: Universitetsforlaget.

Hindar, K. (2011). Evaluering av faktagrunnlaget om påvirkning fra oppdrettslaks på villaks: Lakselus og genetikk. Hentet fra https://brage.bibsys.no/xmlui/bitstream/ handle/11250/2557670/Rapport\%2B20-2011.pdf? sequence=2\&isAllowed=y 
Ingierd, H. (2015). Godt skjønn i formidling av vitenskapelig usikkerhet.

I H. Fossheim \& H. Ingierd (red.), Etisk skjønn i forskning. Sandefjord:

Universitetsforlaget. Hentet fra https://www.idunn.no/etisk-skjonn-i-forskning/ godt-skjonn-i-formidling-av-vitenskapelig-usikkerhet

Karlsen, Ø., Finstad, B., Ugedal, O., \& Svåsand, T. (2016). Kunnskapsstatus som grunnlag for kapasitetsjustering innen produksjonsområder basert på lakselus som indikator. Hentet fra www.imr.no.

Latour, B. (1987). Science in action - how to follow scientists and engineers through society. Cambridge, MA: Harvard University Press.

MacDonald, B., Soomai, S.S., De Santo, E.M. \& Wells, P.G. (2016). Science, information, and policy interface for effective coastal and ocean management: Boca Raton, FL: CRC Press.

Naturmangfoldloven (2009). Lov om forvaltning av naturens mangfold. Klima- og miljøverndepartementet. LOV-2014-06-20-50.

Møklebust, K.A. (2015). Akvakulturanalyse for Sunnhordland og ytre Hardanger, med fokus på laks og regnbogeaure. Hentet fra https://www.hordaland.no/globalassets/ for-hfk/plan-og-planarbeid/regionale-planar-under-arbeid/akvakulturanalyse. pdf:

Nelkin, D. (1975). The political impact of technical expertise. Social Studies of Science, 5(1), 35-54.

NENT. (2016). Forskningsetiske retningslinjer for naturvitenskap og teknologi. https:// www.etikkom.no/globalassets/documents/publikasjoner-som-pdf/60124_fek_ retningslinjer_nent_digital.pdf

NFD. (2017). «Prøvekjøring» av det nye systemet for kapasitetsjusteringer i norsk lakse- og ørretoppdrett [Pressemelding] https://www.regjeringen.no/no/aktuelt/ provekjoring-av-det-nye-systemet-for-kapasitetsjusteringer-i-norsk-lakse--ogorretoppdrett/id2556793/

NFR (2017). Hva skjer med villaksen i havet? 28.08.2017, Forskningsrådet. https://www.forskningsradet.no/no/Nyheter/Hva_skjer_med_villaksen_i_ havet $/ 1254027064782$ ?lang=no

Nilsen, F., Ellingsen, I., Finstad, B., Jansen, P.A., Karlsen, Ø., Kristoffersen, A., \& Myksvoll, M.S. (2017a). Vurdering av lakselusindusert villfiskdødelighet per produksjonsområde i 2016 og 2017. Rapport fra ekspertgruppe for vurdering av lusepåvirkning. Hentet fra https://www.regjeringen.no/contentassets/ b352699b485d471fa5ob9efdffb28dce/ekspertgruppe_hovedrapporten_2017.pdf

Nilsen, R., Serra-Llinares, R., Sandvik, A., Elvik, S.M., Asplin, L., Bjørn, P., \& Lehman, G. (2017b). Lakselusinfestasjon på vill laksefisk langs norskekysten $i$ 2016: Med vekt på modellbasert varsling og tilstandsbekreftelse. Hentet fra Bergen: https://www.hi.no/filarkiv/2017/o1/nr_1-2017_lakselus_sluttrapport_mattilsynet_ nalo_2016.pdf_1/nb-no 
NRK Hordaland (2016, 7. mars). Oppdrettere beskylder forskere for juks i lakselusstudie. https://www.nrk.no/hordaland/oppdrettere-beskylder-forskere-for-juks-ilakselus-studie-1.12840232

Nybø, S., Skarpaas, O., Aslaksen, I., \& Garnåsjordet, P.A. (2011, 7-13.januar). Tallfestet overblikk, kronikk. Morgenbladet.

Olafsen, T., Winther, U., Olsen, Y. \& Skjermo, J. (2012). Verdiskaping basert på produktive hav i 2050. På oppdrag fra NTVA og DKNVS. Hentet fra: https://www. sintef.no/globalassets/upload/fiskeri_og_havbruk/publikasjoner/verdiskapingbasert-pa-produktive-hav-i-2050.pdf

Regjeringen (2017). Regjeringen skrur på trafikklyset. Hentet fra https://www. regjeringen.no/no/aktuelt/regjeringen-skrur-pa-trafikklyset/id2577032/

Skaala, Ø., Kålås, S., \& Borgstrøm, R. (2014). Evidence of salmon lice-induced mortality on anadromous brown trout (salmo trutta) in the Hardangerfjord, Norway. Marine Biology Research, 10(3), 279-288.

Strand, R., \& Oughton, D.H. (2009). Risk and Uncertainty as a Research Ethics Challenge. Oslo: National Committees for Research Ethics in Norway.

Svåsand, T., Grefsrud, E., Karlsen, Ø., Kvamme, B.O., Glover, K., Husa, V., \& Kristiansen, T. (2017). Risikorapport norsk fiskeoppdrett 2017. https://www.imr. no/filarkiv/2017/05/risikorapport_2017.pdf/nn-no

Tollesrud, E., \& Dreyer, H. (2016). Midt i sjøslaget. Morgenbladet. https:// morgenbladet.no/aktuelt/2016/o6/midt-i-sjoslaget

Trellevik, O. (2016). Lakselus, forskning og villfarelse. Morgenbladet.

van der Sluijs, P.J. (2012). Uncertainty and Dissent in Climate Risk Assessment. Nature and Culture, 7(2), 174-195.

van Nes, S., Johansen, L.-H., Gjerde, B., Skugor, S., \& Ødegård, J. (2011). Evaluering av faktagrunnlaget om påvirkning mellom oppdretts-og villaks: Lakselus.

Wynne, B., Callon, M, Concalves, M.E., Jasanoff, S, Jepsen, M, Joly, P.B., Konopasek, Z., May, S., Neubauer, C., Rip, A, Siune, K., Stirling., A., \& Tallacchini. M. (2007). Taking European Knowledge Society Seriously; Report of the Expert Group on Science and Governance to the Science, Economy and Society Directorate, Directorate-General for Research, European Commission. EU. Belgium, Directorate-General for Research Science, Economy and Society.

Yearley, S. (2005). Making sense of science: Understanding the social study of science. London: Sage. 



\title{
Den menneskeskapte iskanten - Om vitenskapelig sannhetssøken og uavhengighet i en kunnskapsbasert forvaltning
}

Ingrid Bay-Larsen

Forskningsleder ved Nordlandsforskning

Erlend A.T. Hermansen

Seniorforsker ved CICERO Senter for klimaforskning

Tone G. Bjørndal

Prosjektleder ved Norsk klimastiftelse

\begin{abstract}
In this chapter we explore how the geographical position of the marginal ice zone in the Barents Sea became the center of a hot political debate. In 2015, new data sets on the retreat of sea ice were introduced by the Norwegian government, indicating how petroleum drilling could take place without conflicting with the vulnerable ice ecosystem. In the public debate that followed, four different definitions of the ice edge zone were introduced, each providing different geographical positions of the ice edge. These multiple definitions directly corresponded to various political views on the exploration of petroleum in the Barents Sea. The analysis shows how ethical principles connected to scientific rigor and independence may be put on trial when conflicts of interests escalate in policy debates. This chapter demonstrates the mismatch between ethical ideals and practice in knowledge-based management, and discusses what their democratic implications might be.
\end{abstract}

Keywords: scientific rigor, scientific autonomy, evidence-based policy, co-production, STS, Arctic

Sitering av dette kapitlet: Bay-Larsen, I., Hermansen, E.A.T., \& Bjørndal, T.G. (2019). Den menneskeskapte iskanten - Om vitenskapelig sannhetssøken og uavhengighet i en kunnskapsbasert forvaltning. I H. Ingierd, I. Bay-Larsen \& K. Hiis Hauge (Red.), Interessekonflikter i forskning (s. 131-151). Oslo: Cappelen Damm Akademisk. https://doi.org/10.23865/noasp.63.ch6

Lisens: CC BY 4.0 


\section{Innledning}

«Vi har ikke flyttet iskanten. Den har flyttet seg selv.»

Det sa statsminister Erna Solberg på konferansen Arctic Frontiers: Climate and Energy i Tromsø 20. januar 2015 (Kristoffersen mfl., 2017). Samme dag skjedde to andre ting: Olje- og energidepartementet annonserte 23. konsesjonsrunde for utvinning av petroleum på norsk sokkel. I denne runden var 34 av totalt 57 blokker (samt deler av blokker) plassert i det sørøstlige Barentshavet. Klima- og miljødepartementet annonserte samtidig at de ville oppdatere datagrunnlaget for å bestemme den geografiske plasseringen av iskanten i Barentshavet. Er det tilfeldig at disse tre hendelsene fant sted samme dag? Neppe. De er nemlig forbundet med hverandre. Nærmere bestemt gjennom det Erna Solberg snakket om: iskanten.

I dette kapittelet analyserer vi definisjonen av iskanten og hvordan den kan knyttes til en større politisk debatt om petroleum, klima og miljø. Var debatten om iskantens definisjon og plassering vitenskapelig eller politisk - eller begge deler? Og kan plasseringen av den «nye» iskanten sies å være kunnskapsbasert? Ekspertkunnskap har en sentral rolle i kunnskapsbasert politikk og forvaltning, og gir et spennende utgangspunkt for å reflektere over grunnleggende forskningsetiske prinsipper som vitenskapens sannhetssøken og vitenskapelig uavhengighet. Dette kapittelet vil gi et bidrag i så måte ved å analysere en case av stor betydning for et oljeland med høye miljø- og klimapolitiske ambisjoner, og med et uttalt mål om å drive kunnskapsbasert forvaltning av det særlige sårbare området rundt iskanten i Barentshavet. Kort fortalt viser analysen at visjonene om uavhengig og objektiv kunnskap står sterkt, selv om praktiseringen av en kunnskapsbasert forvaltning snarere viser en sørpe av kunnskap, politikk, forvaltning, olje, vann og is. Fører dette til en utvanning av forskningsetiske prinsipper? Og hvilke implikasjoner vil dette ha for vårt demokratiske styresett og vår kunnskapsbaserte forvaltning?

\section{Kunnskapsbasert forvaltning}

Kunnskapsbasert forvaltning har en sentral plass i norsk planlegging og forvaltning, og er fremhevet innenfor de fleste samfunnssektorer (St.meld. nr. 19 (1999-200o); St.meld. nr. 42 (200o-2001); St.meld. 
nr. 267 (2004-2005); St.meld. nr. 8 (2005-2006)). Det er høye forventninger til ekspertkunnskapen, også i miljøpolitikken. For det første skal faglig kunnskap bidra til å realisere miljøkonvensjoner om ivaretakelse av natur- og kulturlandskap. For at ikke samfunnsaktiviteter skal true livsbetingelsene for arter eller ødelegge viktige naturområder, må vi ha kunnskap om spesielt verdifulle naturområder og arter for å kunne planlegge og gjennomføre disse aktivitetene på en bærekraftig og forsvarlig måte. Når det gjelder Miljødirektoratets arbeid med å realisere internasjonale målsettinger om ivaretakelse av arter og økosystemer, heter det at «all natur skal forvaltes kunnskapsbasert» (se Miljøverndepartementet, 2012). Også på klimaområdet finnes det lignende målsettinger. For det andre skal kunnskapen bidra til å løse interessekonflikter og dilemmaer i byråkratisk saksbehandling. I saker der ulike hensyn må veies mot hverandre, blir tverrfaglig forskning ansett for å være nøkkelen til å møte beslutningstageres behov; Jo mer kunnskap man har, jo enklere vil det være å ta beslutninger (Norges forskningsråd, 2013). Ekspertkunnskap skal bidra til mer åpenhet og demokrati. En dokumentert prosess, inkludert et solid kunnskapsgrunnlag, vil gjøre det lettere for borgere å gjøre seg kjent med forvaltningens vurderinger og beslutninger. Det er en utbredt tanke at kunnskapen skal fjerne tvil, tette kunnskapshull og eliminere usikkerhet i dagens samfunnsplanlegging (Giddens, 1984; Beck, 1992). Oppsummert kan man si at kunnskap altså har kraft til å underbygge og legitimere politikken. Derfor blir den også en strategisk brikke i et politisk spill med sterke interessemotsetninger.

\section{Vitenskapens sannhetsforpliktelse og kvalitet}

Vitenskapens sannhetsforpliktelse er et grunnleggende forskningsetisk prinsipp. Det er anvendt og anerkjent innen alle disipliner - på tvers av naturvitenskap, humaniora og samfunnsfag. Sannhetsforpliktelsen i en kunnskapsbasert forvaltning er nært knyttet opp mot et overbevisningskrav. For mange er dette selve ankepunktet ved kunnskapens kvalitet. Etterprøvbare argumenter gir utsagn en styrke som kan måles og prøves mot andre utsagn. Bevis blir ofte ansett som den mest overbevisende egenskapen ved et utsagn. Dette vitenskapssynet 
kan også knyttes til Webers verdifrihetstese og en forventning om at vitenskapen skal være objektiv, i den forstand at den ikke er ledet av subjektive verdier og fordommer, men skal gi balanserte fremstillinger (Kaiser, 2015).

Sannhet i form av objektive, vitenskapelig bevis finnes imidlertid først og fremst i en positivistisk vitenskapstradisjon. Som regel må vi forholde oss til forskning og påstander som ikke kan bevises, men som har ulike grader av sannsynlighet. Vitenskapens sannhetsforpliktelse er også sterkt knyttet til kvaliteten på argumenter, ifølge Tranøy (1986). Imidlertid er ikke alle argumenter eller meninger like gyldige. Vitenskapelig kvalitet blir på den måten knyttet til kraften i det bedre argument, som Habermas ville ha kalt det (1982).

Hva er så gyldige argumenter i en kunnskapsbasert forvaltning, og hvordan dannes disse? Ifølge Asdal (2005) har dagens kunnskapsbaserte forvaltningsregime, vokst ut av et industrielt-økonomisk kompleks, et kunnskapshegemoni som skulle stimulere etterkrigstidens ambisjoner om økonomisk utvikling. Sentralt stod forventninger som sprang ut fra et positivistisk vitenskapssyn. Vitenskapen skulle estimere, modellere og gi prognoser til beslutningstagere. Også miljøpolitikken har vokst frem fra et slikt klassisk vitenskapssyn, der akademikere, politikere og opinionen gjentar hvordan «science speaks truth to power»; hvordan kunnskapen kan og skal gi fakta og svar til politikerne (Sundqvist mfl., 2015).

Den empirisk funderte vitenskapssosiologien har lenge vært kritisk til en positivistisk vitenskapstradisjon og til forventninger om objektivitet eller bevisførsel i snever forstand. Forestillingen om at objektive fakta om en ytre natur skal kunne instruere og/eller informere normative slutninger, har lenge vært problematisert innenfor etisk refleksjon. En deskriptiv påstand kan ikke gi normative slutninger, ifølge Hume (1738/2003) som påpekte bristen i å argumentere «fra er til bør». I en fortolkende vitenskapstradisjon ser man ikke på fakta som uavhengig av verdier. Snarere tvert imot hevdes det at etablering av fakta er en prosess som krever en rekke økonomiske og administrative prioriteringer, vitenskapelige og skjønnsmessige vurderinger samt tekniske løsninger (Bay-Larsen, 2014). Et konstruktivistisk vitenskapssyn fremhever derfor hvordan faglig 
skjønn og fortolkning alltid er en del av kunnskapsproduksjonen og forvaltning, og at det derfor ikke finnes vanntette skott mellom kunnskapen og omgivelsene. Et faktum blir sett på som en påstand vi har sluttet å diskutere, og som er blitt stabilisert, hevder Latour (1987). Dette understreker hvordan sannhetssøken og kunnskapens kvalitet betinges av faktumets sosiale aksept. Vitenskapen er derfor ikke verdifri. Tvert imot må kunnskap alltid sees i sammenheng med kontekst. Det ontologiske og det normative, hvordan noe er, og hvordan noe bør være, må forstås som samprodusert, eller to sider av samme sak. Vitenskap og politikk betinger altså hverandre (Jasanoff, 2004).

Inspirert av Sundqvist mfl. (2015) vil vi ta utgangspunkt i at kunnskapsbasert forvaltning vil kunne forstås langs to akser: formalisering og separering. Formalisering handler om vitenskapelig metode og underliggende ontologiske og epistemologiske premisser: Hva er sannhet, og hvordan kan vi vite det vi vet? Separering er knyttet til organiseringen av det vitenskapelige arbeidet: Hvem kan og bør delta i forskningen, og på hvilke premisser? Vi vil argumentere for at disse dimensjonene er nært beslektet med sentrale forskningsetiske prinsipper: vitenskapens fundamentale sannhetsforpliktelse («rigor») og vitenskapelig uavhengighet (separering) (figur 1).

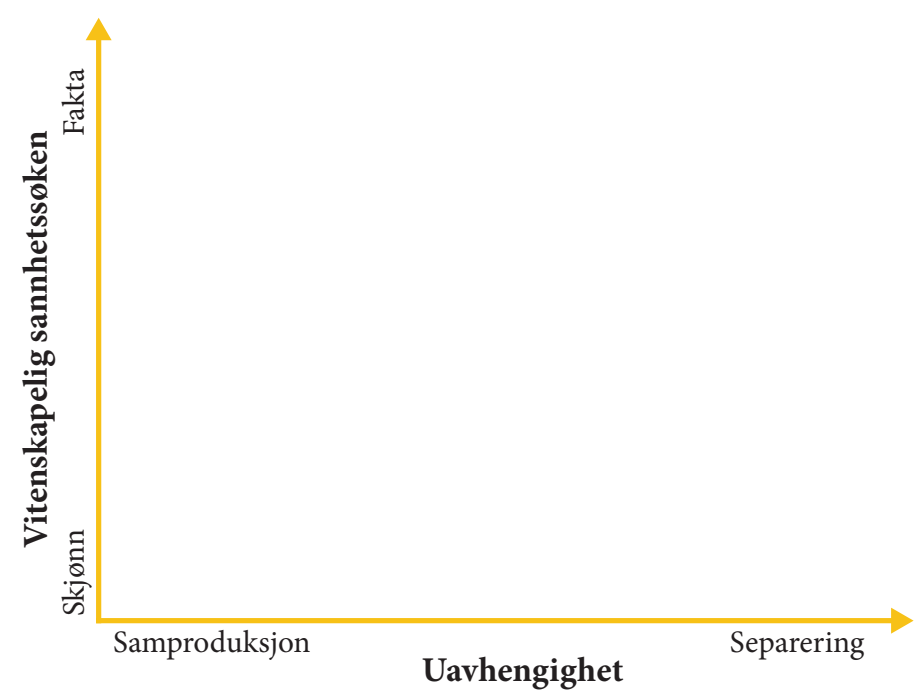

Figur 1. Videreutvikling av Sundqvist mfl. (2015) med to forskningsetiske normer i fokus: vitenskapens sannhetsforpliktelse og vitenskapelig uavhengighet. 
Tilhengerne av evidensbasert praksis, som er nært beslektet med kunnskapsbasert forvaltning, argumenterer oftest ut fra en positivistisk vitenskapstradisjon. «The evidence movement», som kan spores tilbake til medisin (evidence-based medicine), argumenterer for standardiserte metoder og prosedyrer for å velge ut og sammenstille vitenskapelige bevis for implementering i klinisk praksis. I ytterpunktet av aksen finner vi gjerne sannhetssøken gjennom naturvitenskapelige metoder for datainnsamling, bearbeiding og analyse i form av algoritmer og formler. Som et motstykke til «the evidence movement» finner vi den empirisk funderte vitenskapssosiologien. Snarere enn å fremheve standardiserte metoder er vitenskapsstudier (Science and Technology Studies - STS) opptatt av vitenskapelig praksis, altså hvordan forskere faktisk kommer frem til resultater. Et klassisk STS-argument er at all vitenskap er avhengig av «expert judgement», altså eksperters (for)tolkninger og skjønn. Et vitenskapelig resultat vil ytterst sjelden krystallklart åpenbare seg for forskeren, men tvert imot være resultatet av profesjonell fortolkning og analyse (Collins, 1992). Ekspertvurderinger er like viktig i vitenskapelig sannhetssøken som metoder, modeller og «harde» data, hevder STS-forskere. Likeledes er (ekspert)vurderinger viktige i kunnskapsbasert forvaltning, der ekspertene blir bedt om å vise hvilke politiske, miljømessige og økonomiske implikasjoner resultatene fra de vitenskapelige arbeidene har.

\section{Uavhengighet}

I tillegg til sannhetssøken vil ambisjonen om en kunnskapsbasert forvaltning også aktualisere andre forskningsetiske prinsipper, blant annet uavhengighet og grensegangen mellom forskning, politikk og næringsliv. Forskningens uavhengighet er også rotfestet i CUDOS-normene til Merton (Communism, Universalism, Disinterestedness, Organized Scepticism). Fra de forskningsetiske retningslinjene (til NENT og NESH) heter det at både forskerne og forskningsinstitusjonene må unngå å bli avhengige av oppdragsgiverne, fordi det kan svekke deres upartiskhet og den vitenskapelige kvaliteten på forskningen. Den frie forskningen, uten påvirkning fra politikk og næringsliv, er en forutsetning for kunnskapens troverdighet i en kunnskapsbasert politikk og forvaltning. Den gir politikken 
legitimitet, fordi politikerne kan peke på noe utenfor det verdibaserte og subjektive (Wilson, 2010). Kunnskapen kan føres som et bevis for at noen politiske prioriteringer er riktige, mens andre er gale. Og at dette er sant.

Det er derfor viktig å skille mellom den politiske og vitenskapelige sfæren i en kunnskapsbasert politikk og forvaltning. Kunnskapen må vise at den er noe annet enn politikk. Dette er blitt betegnet som separering (Sundqvist mfl., 2015), og handler om den institusjonelle avstanden mellom kunnskapsprodusenter og -brukere. I den ytre enden av skalaen finner man uavhengighet, mens samproduksjon (co-production) befinner seg i motsatt ende. Et skarpt skille, altså full separering mellom forskning og politikk, vil i prinsippet minimere risikoen for påvirkning av forskningsresultater. I en kunnskapsbasert forvaltning er imidlertid relevans nært knyttet til høy kvalitet. Man ønsker kunnskap av høy kvalitet som samtidig er tilpasset politiske problemstillinger, slik at de kan brukes for å løse samfunnsutfordringer. Dette skaper dilemmaer mellom et ønsket avhengighetsforhold og et avhengighetsforhold som svekker forskningens frihet.

Vitenskapelig sannhetssøken, kvalitet, uavhengighet og relevans er knyttet sammen på ulike måter. Det finnes altså ulike idealer for balansegangen mellom disse, og hvordan vi skal organisere kunnskap og politikk i forhold til hverandre. Poenget med figur 1 er ikke å definere de ulike plasseringene som bedre eller dårligere enn andre. Snarere er Sundqvist mfl. (2015) opptatt av at polariserte enten/eller-diskusjoner om den «riktige» posisjonen ikke fører debatten videre. I virkeligheten er det et stort rom for nyanser. Poenget med diagrammet er å illustrere dette rommet med grånyanser som ofte blir usynlige i en kunnskapsbasert forvaltning. Noen argumenterer for mer formaliserte tiltak, for eksempel standardiserte retningslinjer for å oppsummere og bruke forskningsresultater på best mulig måte, mens andre vektlegger betydningen av ekspertvurderinger, uformelle møter og læringsprosesser. Noen argumenterer for mer uavhengig forskning som ikke er påvirket av verdimessige og politiske prioriteringer, mens andre argumenterer for tettere samarbeid mellom forskere og beslutningstakere for å løse samfunnsutfordringer. Målet til Sundqvist mfl. (2015) er altså ikke å komme med en prinsipiell kritikk av en høy grad av formalisering og separering, men snarere av hvordan man kommuniserer og forholder seg til disse idealene. I miljøpolitikken trekkes partene ofte mot 
toppen av aksen, mot en høy grad av formalisering og separering. Gjennom å tilegne kunnskapen kvaliteter i form av objektivitet og uavhengighet, vil man nærmest kunne bevise at den ene eller andre politiske prioriteringen er riktig. Likeledes vil man kunne svekke den politiske motstanderen - ved å vise til hvordan kunnskapsgrunnlaget er tett sammenvevd med subjektive verdier og skjønnsutøvelse.

I opphetede politiske debatter - med sterke interessemotsetninger knyttet til bruk eller vern, petroleum, klima, eller lakselus - vil det kunne oppstå et misforhold mellom hvor man oppgir at man befinner seg, og hvor man faktisk befinner seg (Sundqvist mfl., 2015). Som vi vil se i debatten om iskanten, tok en rekke politiske aktører til orde for en sterk separering og formalisering. Men var det faktisk slik - i praksis? Det er på tide å ta en nærmere titt på prosessen rundt definisjonen av iskanten.

\section{Helhetlig forvaltningsplan Barentshavet}

Saken om iskanten kan spores tilbake til 2002 og faggrunnlaget til den første helhetlige forvaltningsplanen for havområdene Barentshavet og Lofoten, bestilt av Regjeringen Bondevik II gjennom St.meld. nr. 12 (2001-2002) Rent og rikt hav. Men det var først i 2013 at iskanten ble aktuell som sak, og at kontroversen om definisjonen av den blusset opp. Det hele startet da Barentshavet sørøst ble åpnet for petroleumsaktivitet under regjeringen Stoltenberg II, gjennom Meld. St. 36 (2012-2013) Nye muligheter for NordNorge - åpning av Barentshavet sørøst for petroleumsvirksomhet, vedtatt under den rødgrønne regjeringen (Arbeiderpartiet, Sosialistisk Venstreparti og Senterpartiet). I denne stortingsmeldingen står det at man ikke skal ha petroleumsaktivitet i nærheten av iskanten: «I områdene ved iskanten og polarfronten skal det ikke igangsettes petroleumsvirksomhet nå.» Derfor ble det relevant å vite mer presist hvor iskanten faktisk befant seg: Dersom det ikke skal være petroleumsaktivitet i nærheten av iskanten, kan definisjonen og den geografiske plasseringen av den være med å avgjøre hvor det skal være tillatt å drive petroleumsaktivitet. Saken ble spesielt komplisert fordi sentrale aktører deretter definerte iskanten forskjellig. Ikke bare hos meningsmotstandere i partier eller organisasjoner, men også innad i regjeringen og departementene. I tabellen under viser vi en oversikt. 


\begin{tabular}{|c|c|c|}
\hline Aktør & Iskantdefinisjon & Relevante dokument \\
\hline \multirow[b]{2}{*}{$\begin{array}{l}\text { Regjeringen } \\
\text { Stoltenberg II } \\
(2005-2013)\end{array}$} & $\begin{array}{l}\text { Miljøverndepartementet: } \\
\text { Der det er is } 30 \text { prosent av dagene } \\
\text { i april, 1967-1989 (unntatt 1976) } \\
\text { (iskonsentrasjon større enn } 15 \text { prosent) }\end{array}$ & $\begin{array}{l}\text { Miljøverndepartementet: } \\
\text { Helhetlig forvaltning av det } \\
\text { marine miljø i Barentshavet og } \\
\text { havområdene utenfor Lofoten } \\
\text { (forvaltningsplan), (St. meld. nr. } 8 \\
\text { (2005-2006), 2006) }\end{array}$ \\
\hline & $\begin{array}{l}\text { Olje- og energidepartementet: } \\
\text { Den faktiske/observerte iskanten (der } \\
\text { iskanten til enhver tid befinner seg) }\end{array}$ & $\begin{array}{l}\text { Olje- og energidepartementet: } \\
\text { Nye muligheter for Nord-Norge - } \\
\text { åpningen av Barentshavet sørøst } \\
\text { for petroleumsvirksomhet, (Meld. } \\
\text { St. } 36 \text { (2012-2013), 2013) } \\
\text { Tilleggsmelding til Meld. St. } 36 \\
\text { (2012-2013) Nye muligheter } \\
\text { for Nord-Norge - åpning } \\
\text { av Barentshavet sørøst for } \\
\text { petroleumsvirksomhet (Meld. St. } \\
41 \text { Tilleggsmelding til Meld. St. } 36 \\
\text { (2012-2013), 2013) }\end{array}$ \\
\hline $\begin{array}{l}\text { Norsk } \\
\text { Polarinstitutt }\end{array}$ & $\begin{array}{l}\text { Maksimal isutbredelse de siste } 30 \text { år } \\
\text { (iskonsentrasjon større enn } 15 \text { prosent) }\end{array}$ & $\begin{array}{l}\text { Høringsuttalelse - forslag til } \\
\text { utlysning av blokker til } 23 . \\
\text { konsesjonsrunde (Winther \& } \\
\text { Berthinussen, 2014) } \\
\text { Iskant og iskantsone (Norsk } \\
\text { Polarinstitutt, 2014) }\end{array}$ \\
\hline \multirow[t]{2}{*}{$\begin{array}{l}\text { Regjeringen } \\
\text { Solberg (2013-) }\end{array}$} & $\begin{array}{l}\text { Klima- og miljødepartementet: } \\
\text { Der det er is } 30 \text { prosent av dagene i april, } \\
\text { målt fra de siste } 30 \text { år (iskonsentrasjon } \\
\text { større enn } 15 \text { prosent) } \\
\text { Den faktiske/observerte iskanten (der } \\
\text { iskanten til enhver tid befinner seg) }\end{array}$ & $\begin{array}{l}\text { Klima- og miljødepartementet: } \\
\text { Oppdatering av forvaltningsplanen } \\
\text { for Barentshavet og havområdene } \\
\text { utenfor Lofoten med oppdatert } \\
\text { beregning av iskanten, (Meld. St. } \\
20 \text { (2014-2015), 2015) }\end{array}$ \\
\hline & $\begin{array}{l}\text { Olje- og energidepartementet: } \\
\text { Den faktiske/observerte iskanten (der } \\
\text { iskanten til enhver tid befinner seg) }\end{array}$ & \\
\hline
\end{tabular}

Tabell 1. Aktører og deres definisjon av iskanten og relevante dokumenter, etter Bjørndal (2016).

Iskanten omtales både i forvaltningsplanen for Barentshavet og Lofoten fra 2006, 2011 og 2015, og i utlysningsdokumentene i forbindelse med 23. konsesjonsrunde i 2015. I alle disse skriftlige kildene står det at det ikke skal foregå petroleumsaktivitet i nærheten av iskanten. Likevel beskrives den på flere måter i de forskjellige dokumentene. I den første forvaltningsplanen for Barentshavet og Lofoten fra 2006 er iskanten 
illustrert i en figur, og beskrevet som «et spesielt produktivt økosystem i Barentshavet» (Meld. St. 8 (2005-2006), 2006, s. 31).

I den oppdaterte forvaltningsplanen fra 2015 beskrives iskanten som «overgangen mellom tett drivis og åpent hav» (Meld. St. 20 (2014-2015), 2015, s. 13), og defineres som der det forekommer havis $30 \%$ av dagene i april måned, basert på satellittmålinger fra perioden 1985-2014 (Meld. St. 20 (2014-2015), 2015, s. 34), altså en mer formalisert måte å uttrykke iskanten på - som en formel.

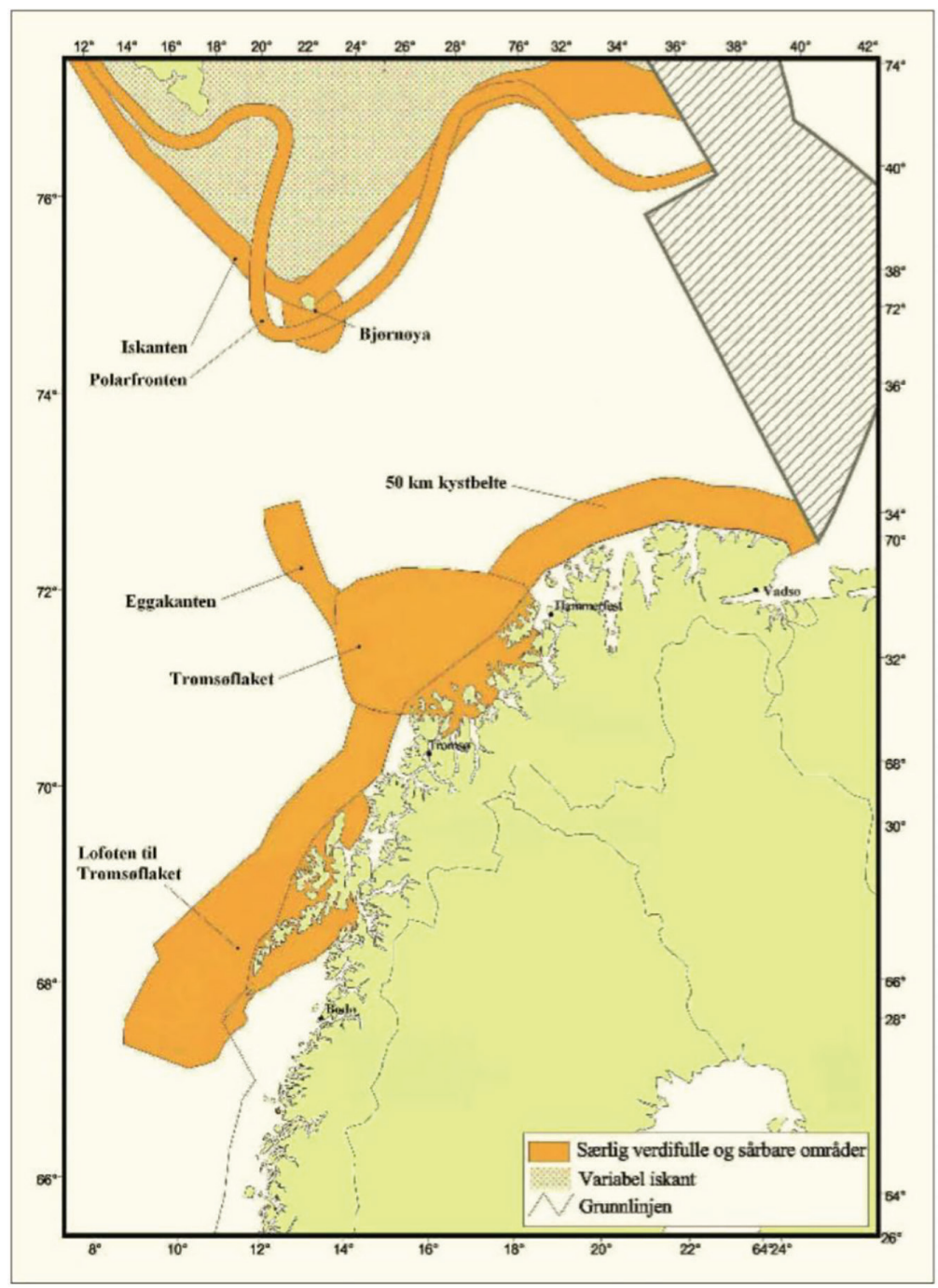

Figur 2. Iskanten illustrert i den første forvaltningsplanen for Barentshavet og Lofoten fra 2006. 
Boks 2.5 Definisjon av iskanten som et særlig verdifullt og sårbart område

Iskanten er definert som et særlig verdifullt og sårbart område som omfatter de havområdene der iskanten vanligvis vil befinne seg gjennom året når den beveger seg frem og tilbake mellom sitt årlige maksimum og minimum. Avgrensningen av iskanten som et særlig verdifullt og sårbart område er satt der det forekommer havis 30 \% av dagene i april måned basert på en tidsserie med satellittobservasjon av isutbredelse for 30-årsperioden 1985-2014. Kriteriet for fore- komst av is er en iskonsentrasjonen større enn $15 \%$, som betyr at isen dekker mer enn $15 \%$ av havoverflaten. Dette er i samsvar med internasjonal standard. Hyppigheten av havis beregnet på denne måten kalles «isfrekvens», og gir på kort sikt et utrykk for sannsynligheten for forekomst av havis i den perioden beregningen er gjort for (se figur $2.21 \mathrm{og} 2.22$ ). Den oppdaterte avgrensningen av iskanten som et særlig sårbart og verdifullt område fremgår av figur 2.23 .

Figur 3. Definisjon av iskanten fra den oppdaterte forvaltningsplanen for Barentshavet og Lofoten (Meld. St. 20 (2014-2015), 2015, s. 34).

Iskanten nevnes også på en tredje måte i den oppdaterte forvaltningsplanen: «I tråd med de rammer Stortinget har sluttet seg til for 23. konsesjonsrunde, settes det tidsbegrensninger for leteboring langs den faktiske/ observerte iskanten (der isen til enhver tid befinner seg) (...)» (Meld. St. 20 (2014-2015), 2015, s. 44, vår understreking). Dette er den samme måten Olje- og energidepartementet beskriver iskanten på. I stortingsmeldingen om åpningen av Barentshavet sørøst (fra Olje- og energidepartementet) fastslås det at det ikke skal forekomme petroleumsaktivitet nærmere enn $50 \mathrm{~km}$ fra den faktiske/observerte iskanten (Meld. St. 36 (2012-2013), 2013, s. 38). Denne meldingen fikk en tilleggsmelding, tilsynelatende på grunn av en feil i trykkeprosessen. Hele tilleggsmeldingen er på to sider, og her byttes punkt 2 og 3 fra den originale meldingen ut. Denne tilleggsmeldingen endret innholdet om iskanten dramatisk. Fra å beskrive hvor og når det ikke er tillatt med leteboring i oljeførende lag, endres dokumentet betydelig:

I områdene ved iskanten og polarfronten skal det ikke igangsettes petroleumsvirksomhet nå. Spørsmålet om petroleumsvirksomhet ved iskanten og polarfronten vil bli vurdert på nytt i forbindelse med neste oppdatering av forvaltningsplanen for Barentshavet. Dette er ikke til hinder for at det kan drives petroleumsvirksomhet i hele Barentshavet sørøst. (Meld. St. 41 Tilleggsmelding til Meld. St. 36 (2012-2013), 2013, s. 2)

Her står det implisitt at iskanten ikke befinner seg i Barentshavet sørøst: Man skal ikke drive med petroleumsvirksomhet ved iskanten, men dette er ikke til hinder for å drive petroleumsvirksomhet i hele Barentshavet 
sørøst. Det er interessant at Olje- og energidepartementet skrev det i 2013, $i$ en tid der den gjeldende forvaltningsplanen for Barentshavet og Lofoten illustrerte at iskanten ligger innenfor Barentshavet sørøst.

Det finnes også forskjellige versjoner av 30 prosent-grensen. De tidligere forvaltningsplanene fra 2006 og 2011 beskriver kun iskanten i form av en figur (se figur 2). Men i den oppdaterte forvaltningsplanen fra 2015, samt i intervjuer fra Bjørndal (2016), står det at forvaltningsplanene fra 2006 og 2011 faktisk benytter data fra perioden 1967-1989 (unntatt 1976). Dette kan man også se i faggrunnlaget til den første forvaltningsplanen fra 2002. Den oppdaterte forvaltningsplanen fra 2015 bruker imidlertid data fra de siste 30 år (1985-2014). Begge dataperiodene avviker fra typiske 30-årsperioder, normalperioder, som man opererer med i meteorologi og klimavitenskap. Den nåværende 30-årsperioden er fra 1961 til 1990, og vil i 2021 endres til å gjelde fra 1991 til 2020. I en verden som allerede påvirkes av klimaendringer, finnes det faglige argumenter for at bruk av en flytende 30 -årsperiode fra den oppdaterte forvaltningsplanen bedre kan illustrere dagens realiteter. Samtidig kan man spørre seg hvorfor denne endringen ble gjort på akkurat dette tidspunktet.

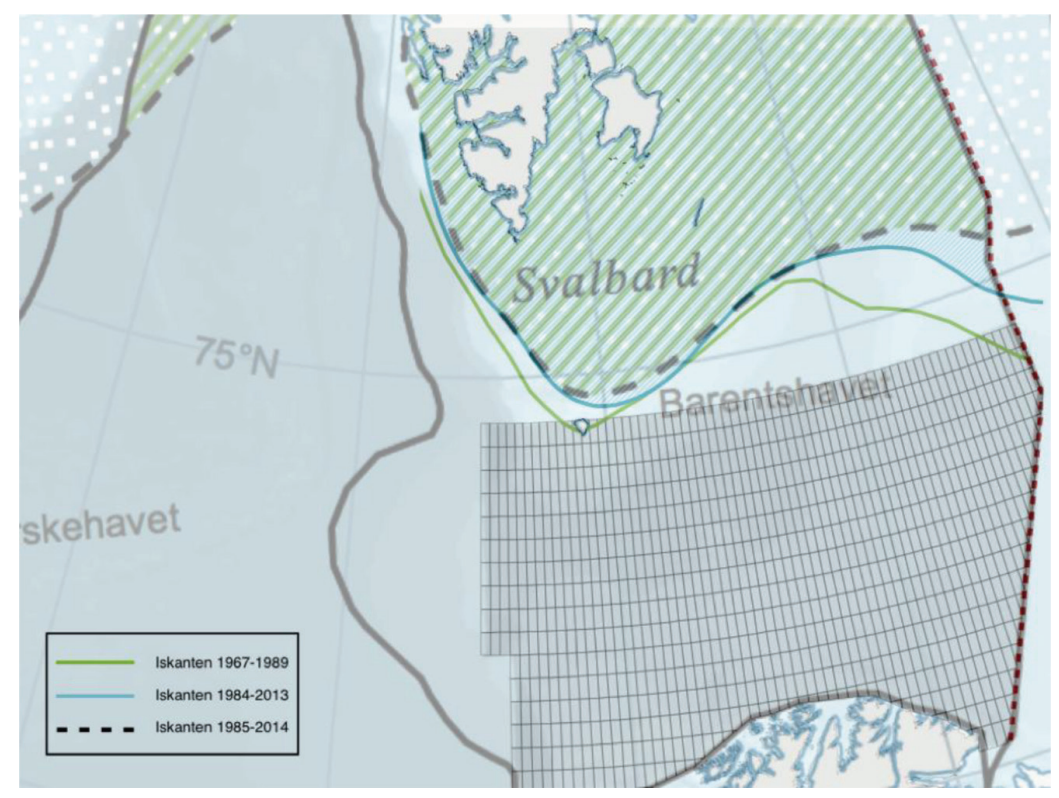

Figur 4. Tre forskjellige iskanter, basert på kart fra den oppdaterte forvaltningsplanen fra 2015 samt Klima- og miljødepartementets annonsering av oppdateringen i januar 2015 (Bjørndal, 2016. s. 48). 
Når man ser på kartene fra forvaltningsplanen for Barentshavet og Lofoten fra 2006 og 2011, synes regjeringens politikk å være motstridende. Ifølge dette kartet vil de utlyste blokkene være i konflikt med iskanten, der leting og utvinning av petroleum skal unngås. I den oppdaterte forvaltningsplanen fra 2015 er derimot iskanten ikke lenger i nærheten av de utlyste blokkene. Dette gjør at petroleumsaktivitet blir mulig lenger nord enn noensinne.

Beskrivelsene og definisjonene av iskanten hos Olje- og energidepartementet og Klima- og miljødepartementet viser at iskanten ikke kan defineres på en enkel måte. Men når definisjonen får store konsekvenser for en viktig sektor som petroleum, og implisitt for miljø og fiskeri, er det også særdeles viktig at den er grundig og entydig. Dette reiser to fundamentale spørsmål om kunnskapsbasert forvaltning: For det første, hva kjennetegner vitenskapelig sannhetssøken og uavhengighet i forvaltningsprosesser med sterke interessekonflikter? For det andre, er den helhetlige forvaltningsplanen for Barentshavet og Lofoten - og debatten om iskanten - eksempler på kunnskapsbasert forvaltning eller forvaltningsbasert kunnskap? Mens den første modellen legger til grunn at kunnskapens rolle er å utrede et politisk spørsmål, vil kunnskapen snarere ha som formål å bekrefte et politisk standpunkt. I den neste seksjonen vil vi drøfte disse spørsmålene mer inngående.

\section{Å formalisere en vitenskapelig sannhetssøken}

Iskanten, eller iskantsonen, er den sonen som skiller åpent hav og havis. Gjennom vitenskapelig sannhetssøken og omforente forutsetninger og definisjoner kan forskerne i utgangspunktet frembringe fakta om hva iskanten er, og hvor den befinner seg. Oseanografi og målinger gjør det mulig å observere dens beliggenhet til enhver tid. I den helhetlige forvaltningsplanen er disse observasjonene tegnet inn på et kart, og iskanten blir et tilsynelatende statisk fenomen uten rom for fortolkninger. Den dynamiske og tredimensjonale iskanten, som egentlig er i konstant bevegelse, tegnes opp som en strek på et papir. Men interessemotsetningene i Stortinget og mellom regjeringene løfter frem alternative definisjoner og plasseringer av denne streken. Med referanse til nyere data fra NPI 
erklærte den norske regjeringen at iskanten hadde flyttet seg nordover. Det endte med at streken, selve definisjonen av iskanten, og hvordan vi skulle oversette observasjonene av iskanten, ble gjenstand for debatt. Debatten om iskanten viste tydelig klassiske utfordringer for vitenskapelig sannhetssøken. Det er rett og slett vanskelig å bevise hva iskanten er, og hvor den befinner seg. Med utgangspunkt i Latour må aktørene bli enige og forhandle for å etablere fakta. Men en omforent definisjon basert på den «best tilgjengelige kunnskap» viste seg å være komplisert. Til det var det for store politiske og økonomiske interesser som stod på spill.

Dette bringer oss til mer grunnleggende spørsmål om kunnskapsbasert forvaltning, vitenskapelig sannhetssøken og etablering av fakta. Er det å definere iskanten et vitenskapelig eller politisk anliggende? Selv om havisen og iskantsonen eksisterer i Barentshavet, er kunnskapen om iskanten menneskeskapt. De geofysiske teoriene, og kartene, er skapt av aktører. Gjennom nitide observasjoner, avansert teknologi og avanserte metoder blir forskerne i stand til å gi sin definisjon av hva iskanten er, og hvor den ligger. Men debatten om hva og hvor iskanten var, levde sitt eget liv, uavhengig av oseanografer og geofysikere. Diskusjonen om å definere et fysisk fenomen (vann i ulike former og fasonger) ble tatt opp av politikerne på Stortinget. Iskanten er altså på samme tid et forvaltningsspørsmål og en politisk sak. Kunnskapen ble en strategisk innsatsfaktor i et politisk spill med sterke interessekonflikter, der politiske motstandere vinner på å fragmentere og hemme kraften i kunnskapsgrunnlaget. De oppdaterte dataseriene fra Polarinstituttet skapte en het debatt i stedet for å komme med et kjølig svar.

På mange måter forflyttes politiske spørsmål om oljeboring i nord over til den akademiske dagsordenen og til drøftinger om definisjoner av iskanten, og videre inn i Stortinget. Det som i utgangspunktet var en politisk uenighet om utlysning av blokker for petroleumsleting i Barentshavet, endte opp i en debatt om vitenskapelige begreper, definisjoner, metoder og tolkninger av data og usikkerhet. Konflikt med viktige politiske mål som petroleumsutvinning, arbeidsplasser og velferd ble et spørsmål om å tolke vitenskapelige observasjoner og målinger. Med andre ord oppstår det en proxy-debatt: en debatt som føres som en vitenskapelig debatt, men som egentlig er en politisk debatt, og delvis føres 
utenfor demokratiske arenaer. Hva sier det om kunnskapens uavhengighet, og om grensen mellom vitenskap og politikk?

\section{Et (u)avhengig kunnskapsgrunnlag}

Debatten om iskanten viser at det er vanskelig å separere kunnskap og politikki en kunnskapsbasert forvaltning. Poenget med kunnskapsbasert forvaltning er å bringe kunnskap og politikkutforming tettere sammen. Kunnskap skal danne grunnlaget for politikk, og da må det være forbindelseslinjer mellom dem. Helhetlig forvaltningsplan Barentshavet viser hvordan produksjon av vitenskapelig kunnskap og politikkutvikling ikke på en enkel måte kan deles inn i to adskilte prosesser. Tvert imot vil en slik forestilling bryte med det som faktisk skjer i praksis. Politikk og kunnskap samproduseres, delvis av de samme aktørene, gjennom (ulike deler av) de samme prosessene. Dette er åpenbart når man for eksempel ser på Norsk Polarinstitutt, hvor samproduksjon av politikk og ekspertkunnskap er institusjonalisert. Polarinstituttet er den statlige institusjonen for kartlegging og gjennomføring av praktiske og vitenskapelige undersøkelser i polarområdene, samtidig som institusjonen er strategisk og faglig rådgiver for forvaltningen i polarspørsmål (Klima- og miljødepartementet, [s.a.]). Med andre ord har instituttet både forsknings- og forvaltningsoppgaver. Polarinstituttet, som ikke ønsker å uttale seg politisk, har publisert to dokumenter som omhandler iskanten: høringsuttalelsen til 23. konsesjonsrunde, og et notat om iskanten som skulle danne grunnlag for den oppdaterte forvaltningsplanen fra 2015. I høringsuttalelsen benytter de den maksimale isgrensen for å beskrive iskanten. Her konkluderer de blant annet med at fire av de utlyste blokkene i konsesjonsrunden berører områdene polarfront og variabel iskant (Winther $\&$ Berthinussen, 2014, s. 3). ${ }^{1}$ I iskantnotatet beskriver de hvordan det er mer anvendelig å benytte maksimums- eller minimumsgrensene for is for å

1 Polarfronten er et område preget av høyt biologisk mangfold, i likhet med iskanten. I forvaltningsplanen fra 2011 står det at det ikke skal igangsettes petroleumsvirksomhet verken ved polarfronten eller ved iskanten i løpet av den daværende stortingsperioden (Bjørndal, 2016). 
beskrive iskanten, ${ }^{2}$ fordi de sier noe om «hvor grensen egentlig ligger og sammen med isfrekvens ${ }^{3}$ hvordan grensen forandrer seg over tid» (Norsk Polarinstitutt, 2014a, s. 6; Bjørndal, 2016). Samtidig står det i notatet at definisjonen som benyttes i forvaltningsplanen, ikke sier noe om variasjon gjennom måneden, og derfor ikke gir noen informasjon om hvor iskanten befinner seg i løpet av samme periode (Norsk Polarinstitutt, 2014a, s. 6).

Polarinstituttet - den offisielle norske kunnskapsleverandøren til norske myndigheter i polarsaker - hevder altså at «maksimal isutbredelse med null prosent isfrekvens» er den mest adekvate definisjonen. En informant ved Polarinstituttet forklarer at det var en faglig beslutning fra deres side: «Vi sier jo det, fra et sårbarhetsperspektiv, at der det er is, der bør det ikke være oljevirksomhet» (Bjørndal, 2016, s. 67). Videre sier vedkommende at det for Polarinstituttet var helt naturlig å bruke maksimal isutbredelse, null prosent isfrekvens, i motsetning til 30 prosent isfrekvens, og at det er viktig å skille mellom en faglig og en politisk vurdering: «Faglig er det jo helt logisk å bruke nullprosentlinjen. (...) Så vi må skille veldig på en faglig vurdering og en politisk vurdering» (Bjørndal, 2016, s. 67). Her kommer det altså tydelig frem at Polarinstituttet mener det faglig forsvarlige er å bruke maksimal isgrense i stedet for 30-prosent-grensen som faktisk benyttes.

Eksempelet iskanten viser en samproduksjon av kunnskap, politikk, olje, vann og is. Snarere enn en separert og lineær prosess er det snakk om iterative prosesser der kunnskap og politikk utvikles i et tett samspill med hverandre, og der tilsynelatende formalisert naturvitenskap oversettes og fortolkes. Å lage en definisjon er derfor et resultat av et høyt antall forhandlinger, kompromisser mellom verdier og interesser, observasjoner og modeller av biologiske, kjemiske og fysiske fenomener - og ikke minst penger og kompetanse satt av til kartlegginger.

2 Maksimum og minimum isutbredelse viser til utbredelsen av is (15 prosent eller mer) i løpet av en gitt periode (Norsk Polarinstitutt, 2014a).

3 Isfrekvensen sier noe om hvor mange dager i løpet av en periode det er is i et gitt område. Dersom det er 10 prosent isfrekvens i en periode på 100 dager, har det forekommet is i det området i 10 av de 100 dagene. Isfrekvensen sier kun at det har vært is et sted, ikke noe om hvor mye is det har vært (Bjørndal, 2016). 


\section{Evidens og uavhengighet - misforhold mellom etos og praksis}

De vitenskapelige idealene om formalisering og separering er ifølge Sundqvist mfl. (2015) kanoniske, altså tungt innarbeidet i den vitenskapelige diskursen, og ikke minst i synet på hvordan vitenskap skal forholde seg til politikk. Polarinstituttet ble stilt i en vanskelig situasjon. For å være tro mot idealene i en kunnskapsbasert forvaltning må de plassere seg høyt oppe på begge akser, med høy grad av separering og tunge, objektive fakta. Som kunnskapsleverandør skal de gi en objektiv beskrivelse av iskantsonen - de skal ikke blande seg i politiske prioriteringer. Men da debatten om å definere iskanten flyttet inn på Stortinget, ble Polarinstituttet ute av stand til å gi et entydig, klart svar på hvordan observasjonene skulle tolkes. Det lot seg ikke gjøre å bevise hvor iskanten egentlig var plassert, uten samtidig å ta stilling til et politisk spørsmål om petroleumsutvinning.

Ved å studere hvordan forskningsetiske idealer utøves i praksis snarere enn å hevde viktigheten av dem - kan vi få en mer nyansert debatt om hva kunnskapsbasert forvaltning faktisk innebærer av forhandlinger, gråsoner, utfordringer og muligheter. Problemene oppstår når vi påstår vitenskap er uavhengig og fri for politikk og verdier, mens det i praksis foregår et politisk spill, forkledd som en definisjon av geofysiske fenomener og tolkning av data. Eller hvis forvaltningen eller andre aktører har en forestilling og en forventning om at mer og bedre kunnskap skal løse verdikonflikter og fjerne tvil og usikkerhet. Debatten om iskanten demonstrerte det motsatte. Observasjoner og fakta i seg selv gir ikke svar på kompliserte politiske spørsmål. Når aktørene observerer, definerer og analyserer iskanten, gir de samtidig innhold og mening til et politisk standpunkt. De nye dataene kom ikke alene. De hadde følge av politiske ambisjoner om næringsutvikling eller vern. Det nye datasettet var inngangsbilletten til petroleumsutvinning lenger nord og øst i Barentshavet.

Caset om iskanten illustrerer derfor med all tydelighet et misforhold mellom våre forventninger til kunnskap som uomtvistelig, fri og uavhengig, og den samproduksjonen som foregår. Det er altså et misforhold mellom idealer og praksis i kunnskapsbasert forvaltning. 


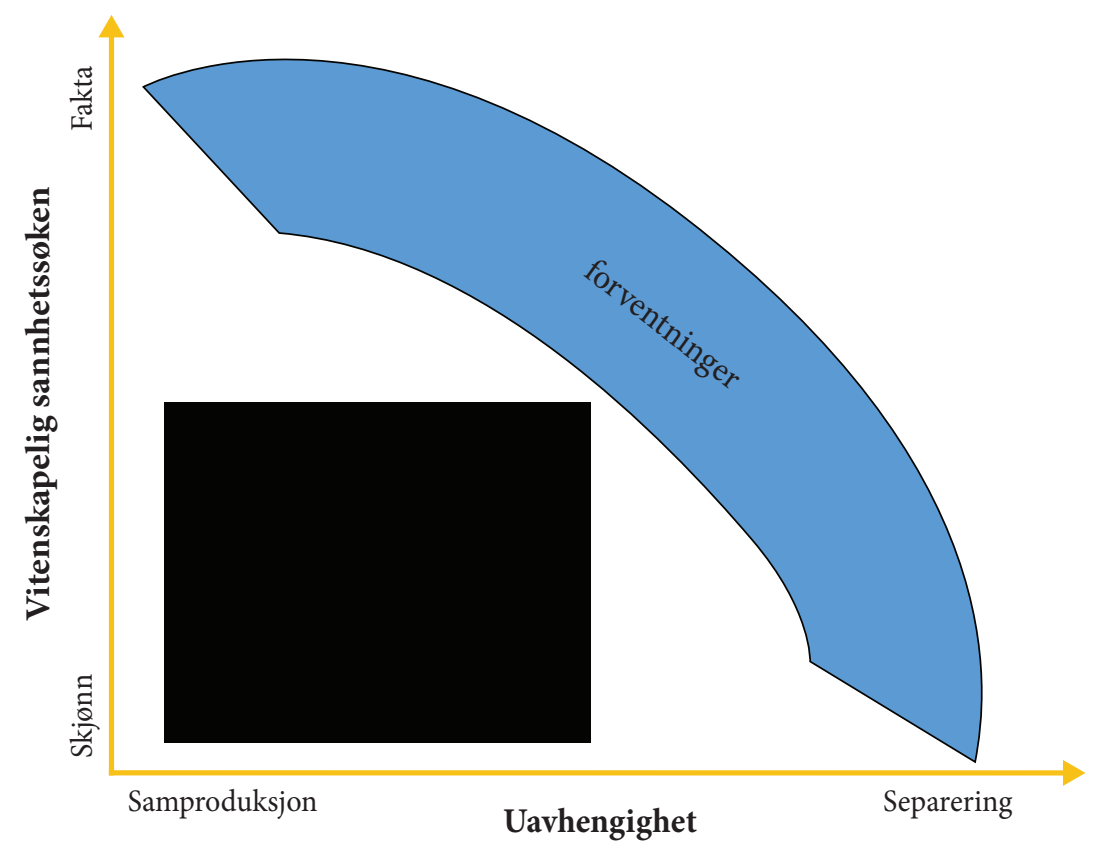

Figur 5. Brist mellom forventninger til vitenskapelig sannhetssøken og uavhengighet, versus praksis (den sorte boksen) i kunnskapsbasert forvaltning. Kan det at slike debatter foregår i en sort boks føre til mindre åpenhet rundt skjønnsmessige vurderinger, fortolkninger, usikkerhet og uavhengighet i demokratiske beslutningsprosesser?

Hvilke konsekvenser har så dette gapet mellom idealer og praksis for vårt demokratiske styresett og vår kunnskapsbaserte forvaltning? En åpenbar bekymring vil være at dette misforholdet gjør det utfordrende å være åpen på praksis. I en verden som forventer objektive fakta og uavhengig kunnskap, blir det fort kontroversielt å kommunisere hvordan kunnskapen faktisk samproduseres mellom akademia, politikere og byråkrater. Forventningene om en uavhengig og objektiv ekspertkunnskap rettes mot politikere og eksperter i fellesskap. De har derfor også en felles interesse i å skjule samproduksjon, usikkerhet og skjønnsmessige vurderinger - fordi det strider mot idealene. Dette gjør vitenskapen mindre troverdig, og politikken mindre legitim, i en og samme prosess. Å skjule praksis gir derfor mindre rom for åpen diskusjon, og mer rom for spekulasjon og strategisk spill.

Så hvordan kan man lukke gapet mellom idealer og praksis? Må vi justere idealene våre? Eller insistere sterkere på dem? For å styrke en kunnskapsbasert forvaltning for fremtiden bør vi åpent anerkjenne at forskning og politikk betinger hverandre, i ulike grader i ulike situasjoner, i stedet 
for å strebe etter uoppnåelige idealer. At det finnes flere typer vitenskap, og flere typer kunnskap enn vitenskap, er basale erkjennelser som må ligge i bunnen av vår forståelse av kunnskapsbasert forvaltning. Vi bør derfor søke etter konstruktive måter å håndtere dette på (Funtowicz \& Ravetz, 1991, 1993; Callon mfl., 2009). Som Tranøy påpeker: Sannhetssøken skjer ikke utelukkende via formaliserte vitenskapelige prosedyrer, men også gjennom sosiale prosesser, utenfor akademia (Tranøy, 1986).

Ekspertvurderinger er nødvendig i kunnskapsbasert forvaltning. Men det kan ikke erstatte åpenhet rundt verdimessige og politiske standpunkt, og den fargen dette gir politiske analyser og konklusjoner. Politikk hviler alltid på mer enn bare vitenskap, og det er legitimt i demokratier. Men vi må være ærlige om hva som er vurderinger, og hva som er den «beste» omforente kunnskapen, om den i det hele tatt finnes. Debatten om iskanten demonstrerer også hvordan norske myndigheter innimellom bryter med det faglige rådet fra sin offisielle kunnskapsleverandør. Når regjeringen velger å overkjøre faglige råd fra sin egen offisielle kunnskapsleverandør, og Polarinstituttet unnlater å påpeke dette i offentligheten, kan man spørre om det råder en snever forståelse av faglig uavhengighet i vår kunnskapsbaserte forvaltning. I retningslinjene fra den nasjonale forskningsetiske komité for samfunnsvitenskap og humaniora (NESH) står det at blant annet forskere, organisasjoner og forvaltningsorganer bør engasjere seg i samfunnsdebatter om rimelige fortolkninger av forskningsresultater. Som dette kapittelet har vist finnes det gode argumenter for at denne retningslinjen også bør gjelde for naturvitenskapelig og teknologisk forskning. Det er legitimt at politikere i et demokrati vil bore etter olje i Arktis. Men da bør de også være ærlige på at dette går på tvers av de beste omforente faglige rådene. Hvis ikke ender man lett opp $i$ en proxy-debatt, der man tilsynelatende diskuterer grensen for iskanten og ulike faglige definisjoner av den, mens det man egentlig debatterer, er hvor langt nord man ønsker å bore etter olje. Slike pseudo-tekniske debatter er hva Latour kaller "politics by other means» (Latour, 1988). Og dette er problematisk i demokratier, fordi det kan føre til illegitim maktutøvelse utenfor etablerte demokratiske arenaer og kanaler. Derfor bør vi ha innsyn, åpenhet og en bred refleksjon rundt begrensningene og mulighetene ved kunnskapen i en kunnskapsbasert forvaltning. 


\section{Referanser}

Asdal K. (2005). Returning the Kingdom to the King. Acta Sociologica 48: 253-261.

Bay-Larsen, I. (2014). Kunnskap i norsk miljøplanlegging - relevans, troverdighet og legitimitet. Kart og plan 74, 266-279.

Beck, S. (2012). From truth to trust: Lessons learned from "Climategate”. I K. Hogl, E. Kvarda, R. Nordbeck \& M. Pregernig (Red.), Environmental governance - the challenge of legitimacy and effectiveness (s. 220-42). Cheltenham UK: Edward Elgar.

Bjørndal, T.G. (2016). Iskanten: På grensen mellom vitenskap og politikk

(Masteroppgave). Senter for teknologi, innovasjon og kultur, Universitetet i Oslo.

Callon, M., Lascoumes, P., \& Barthe, Y. (2009). Acting in an uncertain world: An essay on technological democracy. Cambridge, MA: MIT Press.

Collins, H.M. ([1985] 1992). Changing order: Replication and induction in scientific practice (2. utg.). Chicago, IL: The University of Chicago Press.

Funtowicz, S.O., \& Ravetz, J.R. (1991). A new scientific methodology for global environmental issues. I R. Costanza (Red.), Ecological economics: The science and management of sustainability (s. 137-152). New York, NY: Columbia University Press.

Funtowicz, S.O., \& Ravetz, J.R. (1993). Science for the post-normal age. Futures, $25(7), 739-755$.

Giddens, A. (1984). The constitution of society. Outline of the Theory of Structuration (s. 334). Cambridge: Polity Press.

Hume, D. (2003). A treatise of human nature. Dover Philosophical Classics edition (a reprint of the original 1739 edition). Mineola, NY: Dover Publications.

Jasanoff, S. (2004). States of knowledge: The co-production of science and social order. London: Routledge.

Klima- og miljødepartementet. (s.a.). Norsk Polarinstitutt. Lastet ned fra https:// www.regjeringen.no/no/dep/kld/organisasjon/underliggende- etater/norsk_ polarinstitutt/id85703/

Kristoffersen, B., \& Steinberg, P. (2017). "The ice edge is lost...Nature moved it": Mapping ice as state practice in the Canadian and Norwegian North, Transactions of the Institute of British Geographers, 42 625-641. https//doi. org/10.1111/tran.12184

Latour B. (1987). Science in action: How to follow scientists and engineers through society, Milton Keynes: Open University Press.

Latour, B. (1988). The Pasteurization of France. Cambridge, MA: Harvard University Press.

Meld. St. 20 (2014-2015) (2015). Oppdatering av forvaltningsplanen for Barentshavet og havområdene utenfor Lofoten med oppdatert beregning av iskanten. Klimaog miljødepartementet. 
Meld. St. 36 (2012-2013) (2013). Nye muligheter for Nord-Norge - åpningen av Barentshavet sørøst for petroleumsvirksomhet (Meld. St. 36). Olje- og energidepartementet.

Meld. St. 37 (2012-2013) (2013). Helhetlig forvaltning av det marine miljø i Nordsjøen og Skagerrak. Miljøverndepartementet.

Meld. St. 41, Tilleggsmelding til Meld. St. 36 (2012-2013) (2013). Tilleggsmelding til Meld. St. 36 (2012-2013) Nye muligheter for Nord-Norge - åpning av Barentshavet sørøst for petroleumsvirksomhet (Meld. St. 41). Olje- og energidepartementet.

Miljøverndepartementet (2012). Naturmangfoldloven kapittel II - Alminnelige bestemmelser om bærekraftig bruk - en praktisk innføring (veileder). Miljøverndepartementet.

Norges forskningsråd (2013). Ser stort på miljøforskningen - møter miljøkonflikter med kunnskap. Tilgjengelig fra: http://www.forskningsradet.no/prognettmiljo2015/Nyheter/Ser_stort_pa_miljoforskningen__moter_miljokonflikter_ med_kunnskap/1253983448441. 25 Juni 2014.

Norsk Polarinstitutt (2014). Iskant og iskantsone - fremstilling av iskantsonen som sårbart areal.

St.meld. nr. 8 (2005-2006) (2006). Helhetlig forvaltning av det marine miljø i Barentshavet og havområdene utenfor Lofoten (forvaltningsplan). Miljøverndepartementet.

St.meld. nr. 12 (2001-2002) (2002). Rent og rikt hav. Miljøverndepartementet.

Sundqvist, G., Bohlin, I., Hermansen, E.A.T., \& Yearley, S. (2015). Formalization and separation: A systematic basis for interpreting approaches to summarizing science for climate policy. Social Studies of Science, 45(3), 416-440.

Tranøy, K.E. $(1986,1991)$. Vitenskapen - samfunnsmakt og livsform. Oslo: Universitetsforlaget.

Winther, J.G., \& Berthinussen, I. (2014). Høringsuttalelse - forslag til utlysning av blokker til 23. konsesjonsrunde. Norsk Polarinstitutt. 



\title{
KAPITTEL 7
}

\section{Forskning for politikk: Om uavhengighet i direktoratsektoren}

\author{
Gisle Andersen
}

Seniorforsker ved NORCE Samfunn Rokkansenteret

\begin{abstract}
This chapter analyzes the establishment of ecosystem-based petroleum management in Norway since 2001. Based on interviews with researchers involved in the processes and document analysis, it is argued that research has a much less autonomous role for policy development than the public debate presupposes. Rather than being a scientific corrective to policy, research is deeply intertwined with political decision-making and management processes. This is often the case when research is to inform policymakers. What is particular in this case, is the organization of research. The core research institutions are themselves hybrids, as the boundary between science and policy is drawn within these institutions. This way of organizing research is resource-effective, flexible and secure policy-relevant knowledge creation. However, it also reduces researchers' autonomy, it puts limits on when and how they choose to participate in public debates, and it can create a false impression of knowledge consensus. The prevailing organization of research makes it easier to define policy decisions as "knowledge-based", but at the same time potentially limits the quality of knowledge available to the public. Rather than asking for "purer" knowledge production, we need to discuss the consequences of different ways of organizing policy-relevant knowledge creation.
\end{abstract}

Keywords: autonomy, knowledge-consensus, policy-relevant research, organization of research

\section{Introduksjon}

Hvilken rolle har forskning og andre kunnskapsprosesser spilt for utformingen av norsk petroleumspolitikk fra $2001 \mathrm{og}$ frem til i dag? Oppmerksomheten i dette kapittelet skal særlig rettes mot det som kan kalles petroleumspolitikkens marine miljødimensjon - konsekvensene

Sitering av dette kapitlet: Andersen, G. (2019). Forskning for politikk: Om uavhengighet i direktoratsektoren. I H. Ingierd, I. Bay-Larsen \& K. Hiis Hauge (Red.), Interessekonflikter i forskning (s. 153-175). Oslo: Cappelen Damm Akademisk. https://doi.org/10.23865/noasp.63.ch7

Lisens: CC BY 4.0 
petroleumsaktivitetene har for livet i havet. Mange av endringene på feltet er knyttet til stortingsmeldingen Rent og rikt hav, som ble fremmet våren 2002 (St.meld. nr. 12 (2001-2002)). Meldingen slo fast at man manglet en tilstrekkelig forståelse av petroleumsnæringens miljøpåvirkning. Det ble derfor igangsatt en rekke prosesser for å gi et bedre grunnlag for en helhetlig eller økosystembasert havmiljøpolitikk, «dvs. en politikk hvor summen av alle påvirkninger vurderes i sammenheng og baseres på kunnskap om økosystemenes struktur, virkemåte og tilstand» (St.meld. nr. 12 (2001-2002), s. 15). Det ble også påpekt at bruken av havet var preget av sektor- og næringsinteresser. Selv om de ulike aktørene tok miljøhensyn, var det et problem at tiltak og inngrep ofte ble gjort «uten grunnlag i tilstrekkelig kunnskap om sammenhengene mellom belastningene og effektene på økosystemene» (ibid., s. 13). Kunnskapsgrunnlaget ble omtalt som «mangelfullt», og ytterligere «forskning og kartlegging» var nødvendig for å etablere en mer økosystembasert havforvaltning (ibid., s. 22).

For å løse denne utfordringen skulle man utvikle kunnskapsbaserte forvaltningsplaner som definerte noen overordnede rammer for næringsaktivitet. Tanken var at forvaltningsplanene skulle gi et faglig fundament for å legge begrensninger på bruken av havområdene. På den måten ville regjeringen «sikre konsensus om retningslinjene og redusere mulighetene for konflikter mellom forskjellige interesser» (ibid., s. 21). Sitatene ovenfor - og særlig bruken av ordet «konsensus» - illustrerer hvilken rolle forskningsaktiviteter ble tillagt i denne prosessen: Gjennom å etablere et felles faktagrunnlag om miljøstatus for havområdene og virkninger av menneskelig aktivitet skulle man få et lavere konfliktnivå og en bedre koordinering på tvers av sektorer.

At meldingen la vekt på at ny og bedre kunnskap om miljøpåvirkning kunne løse interessekonflikter mellom sektorer, kan tolkes i lys av at det i flere år hadde pågått en diskusjon om miljøkonsekvensene ved petroleumsaktivitet. Våren før meldingen ble lansert, hadde Regjeringen innført et midlertidig forbud mot leteboring etter petroleum - et moratorium - i hele det nordlige havområdet. I pressemeldingen som ble sendt ut, ble boreforbudet eksplisitt begrunnet med endret kunnskap om miljørisikoen. 
Vi har fått ny kunnskap om konsekvensene av petroleumsvirksomhet i slike miljøsårbare områder. Ny forskning viser at kjemikalieutslipp kan true gyte- og oppvekstmulighetene for fisk og sjøfugl, sier [miljøvernminister] Siri Bjerke. (Regjeringen Stoltenberg I, 2001)

Den nye kunnskapen det ble vist til, var eksperimentelle studier ved Havforskningsinstituttet som undersøkte hvordan torskens reproduksjonsevne kunne bli påvirket av svake konsentrasjoner av olje. Eksperimentet var utformet for å etterligne produsert vann, som slippes ut fra petroleumsinstallasjoner (Meier et al., 2002). De foreløpige resultatene fra prosjektet var klare høsten 2000 og førte både til avisoppslag (Haukli, 200o) og til et bekymringsbrev fra Statens forurensningstilsyn til Miljøverndepartementet (SFT, 2001).

Sammen med stortingsmeldingen Rent og rikt hav utgjorde moratoriet i 2001 startskuddet for omfattende forsknings- og utredningsprosesser som har resultert $\mathrm{i}$ «helhetlige» forvaltningsplaner for alle de norske havområdene. Hendelsesforløpet kan tolkes som at forskning hadde spilt en rolle for politikkutforming: Nye forskningsresultater hadde gitt grunnlag for en politisk beslutning om å stoppe leteboring etter olje. Deretter ble det satt i gang et forskningsarbeid for å legge et bedre fundament for retningslinjene for bruken av havområdene. Dette er tilsynelatende i tråd med det som kan forstås som en idealmodell for forskningens betydning for politikk (Douglas, 2009). Den forstår forskning som en autonom og sannhetssøkende aktivitet. Derfor kan det frembringes ny kunnskap som igjen kan korrigere politiske beslutninger og forme politiske målsettinger. På den måten kan forskning bidra til en kunnskapsbasert politikk, som i denne sammenheng kommer til uttrykk i etableringen av en økosystembasert petroleumsforvaltning.

Dette er helt klart én av dimensjonene ved relasjonen mellom forskning og politikk på dette feltet. Men denne dimensjonen er utilstrekkelig for å forstå forskningens betydning og begrensning i relasjon til politikkutforming. Resten av dette kapittelet skal særlig ta for seg prosessen fra $2001 \mathrm{og}$ frem til 2015, og vil belyse tre andre dimensjoner ved denne relasjonen: 
1) For å kunne bidra tilå løse politiske problemer er det som en hovedregel avgjørende at forskningen kommer med relativt klare svar. Faglig uenighet blir derfor ofte ansett som et problem; faglig konsensus er ønskelig.

2) I Norge har vi en ganske stor forskningssektor som er innrettet mot å drive forskning for politikk. Denne er ofte organisert med begrenset formell autonomi og består av forskningsinstitutter som er underlagt et departement. De er formelt sett fagdirektorater og er en del av statsbyråkratiet. Således er de en del av en hierarkisk linjeorganisasjon preget av vertikalfordelt autoritet. Her blir dette omtalt som «direktoratsektoren», og det blir argumentert for at dette er en tredje og ofte oversett forskningssektor som spiller en vesentlig rolle i politikkutformende prosesser.

3) Mange av spørsmålene som forskningsinstituttene i direktoratsektoren arbeider med, er både faglige og politiske. Slik forskning for politikk er viktig og nødvendig for de politiske prosessene. Å rendyrke det arbeidet som direktoratsektoren gjør som enten faglig eller politisk, er ikke nødvendigvis en god løsning, men måten sammenvevingen av faglige og politiske hensyn blir gjort på, har likevel en rekke konsekvenser. Den setter rammer for samhandlingen mellom forskere og politiske aktører, og for hvordan forskningsbasert kunnskap brukes i den brede offentlighet og i politiske beslutningsprosesser.

Analysen i kapittelet underbygger at vi trenger en bred offentlig debatt om hvordan kunnskapen er organisert og knyttet til politiske prosesser, men den gir også innsikt i hvorfor en slik debatt er vanskelig å få til.

\section{Metode og empiri}

Dette kapittelet er en omarbeidet og forkortet versjon av kapittel 8 og 9 i Andersen (2017), og en del av teksten er hentet fra denne publikasjonen. Det underliggende forskningsarbeidet analyserer dokumenter fra arbeidet med forvaltningsplanene, både fra den formelle politiske saksbehandlingen (stortingsmeldinger, innstillinger, stortingsdebatter), fagrapporter, miljørisikoanalyser og kunnskapsoppsummeringer fra både forskningsinstitusjoner og 
konsulenter (se Andersen, 2017: 710-733 for en full oversikt). I tillegg kommer 13 forskningsintervjuer med forskere og rådgivere ved Havforskningsinstituttet og Norsk Polarinstitutt i 2010 og 2011. De fleste av disse hadde vært involvert i arbeidet med forvaltningsplanene. ${ }^{1}$ Analysen av det empiriske materialet er brukt for å løfte frem problemstillinger knyttet til faglig uavhengighet. Kapittelet bygger altså på en på en større studie av den historiske utviklingen av miljø- og petroleumspolitikken i etterkrigstiden. Derfor er det grunnlag for å hevde at dimensjonene som diskuteres her, ikke er unike for forvaltningsplanprosessen etter 2001, men at de representerer generelle trekk ved relasjonen mellom forskning og politikk på miljøfeltet i Norge.

\section{Etablering av en ny havmiljøpolitikk og endring av forskningen på feltet}

Prosessen som ble satt i gang med moratoriet og Rent og rikt hav, hadde et klart formål. Den skulle gi et grunnlag for å utforme en ny havmiljøpolitikk. Det var en klar politisk forventning om at det skulle finne sted en forskningsbasert kunnskapsproduksjon som var relevant for den politiske målsettingen om å etablere en mer økosystembasert havmiljøpolitikk (St. meld. nr. 12 (2001-2002), s. 21, og Stortingets behandling av meldingen i S.tid. 2002-2003, s. 2305-2321). Mens vitenskapsbasert kunnskap spilte en vesentlig rolle i å problematisere havmiljøpolitikken før 2002, var altså planen at forskning skulle ha en konstruktiv rolle i politikkutformingen. Prosessen skulle gi grunnlag for å utforme en ny politikk. Siden 2001 har arbeidet med å legge og senere revidere kunnskapsgrunnlag for forvaltningsplanene vært organisert på litt varierende måter. Grunnprinsippene kan likevel oppsummeres som i figur 1.

Det faglige grunnlaget har blitt lagt i form av en lang rekke rapporter. Bare i tilknytning til forvaltningsplanen for Lofoten og Barentshavet ble det i perioden 2003 til 2011 laget rundt to hundre faglige rapporter med et omfang fra alt fra ti til tre hundre sider. ${ }^{2}$ De færreste av disse er

1 Av hensyn til informantenes anonymitet oppgis kun arbeidssted når disse siteres. For at leseren skal kunne skille informantene fra hverandre, er intervjuene nummerert fra 1 til 13.

2 Dette tallet inkluderer samtlige faglige grunnlagsrapporter fra prosessen med forvaltningsplanen for Lofoten og Barentshavet fra $2003 \mathrm{og}$ frem til revisjonen av forvaltningsplanen i 2011. De 


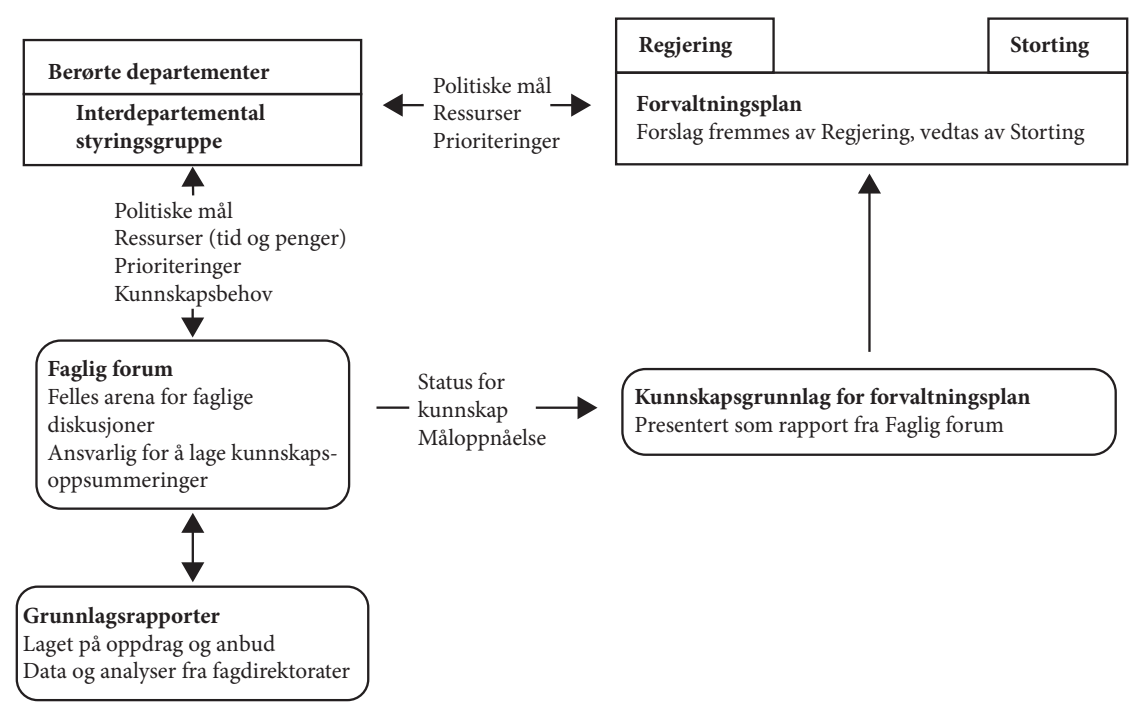

Figur 1. Illustrasjon av hvordan kunnskapsproduksjonen i forvaltningsplanen har vært organisert.

forskningsrapporter i den forstand at de ville ha egnet seg for publisering $\mathrm{i}$ et vitenskapelig tidsskrift. Grunnlagsrapportene er typisk vurderinger som tar i bruk vitenskapelige metoder og tilnærminger for å belyse spørsmål som er relevante for forvaltningsplanarbeidet. De redegjør for hvilke data og metoder man bygger på, og de gir referanser til publiserte og upubliserte studier samt rapporter for å underbygge egne vurderinger og analyser.

Ansvaret for å koordinere og sammenfatte alle disse rapportene har blitt lagt til Faglig forum, et sett med faggrupper. Medlemmene i disse gruppene har i hovedsak kommet fra direktorater og forskningsinstitutter, men også enkeltforskere har deltatt. Norsk Polarinstitutt (NP), Kystverket (KYD) og Havforskningsinstituttet (HI), Miljødirektoratet, Oljedirektoratet (OD) og Petroleumstilsynet (PTIL) har hatt viktige funksjoner. Analysen av prosessene viser at HI og NP er helt sentrale når det gjelder å gjennomføre deler av forsknings- og overvåkningsarbeidet på miljøfeltet. Årsaken er at disse instituttene har relevante forskningsprogram og har ansvar for en lang rekke vesentlige overvåkings- og kartleggingsaktiviteter, også på tilstøtende områder. Havforskningsinstituttet gjennomfører eksempelvis årlige tokt i norske havområder, hvor de samler inn relevante data.

fleste av disse rapportene er samlet på nettsidene til Miljøverndepartementet og Norsk Polarinstitutt (se Norsk Polarinstitutt, 2015). 
Faglig forum har også hatt som oppgave å identifisere hvilke grunnlagsrapporter som trengs, og har satt slike oppdrag ut på anbud, i tillegg til å oppsummere og syntetisere grunnlagsrapportene. Medlemmer av forumet har vært redaktører for kunnskapsoppsummeringer som har lagt et faglig grunnlag for forvaltningsplanene. Disse oppsummeringsrapportene er således sentrale i overføring av vitenskapsbasert kunnskap til departementene. Kunnskapsoppsummeringene er ment å være rådgivende for den videre politiske prosessen. De skal gjøre opp status «for kartlegging, forskning og overvåking», de skal vurdere «måloppnåelse» (i forhold til forvaltningsplanen), og de skal gjøre rede for «viktige utviklingstrekk og ny kunnskap» ([Anon], 2006a, 2006b). Faggruppene har også hatt en politisk forankring i en styringsgruppe med representanter fra overordnede departementer.

Forslaget til forvaltningsplaner ble utarbeidet i Klima- og miljødepartementet. Forslaget ble så fremmet av regjeringen som en stortingsmelding, før det ble behandlet og endelig vedtatt i Stortinget. Når Stortinget vedtok den første forvaltningsplanen i 2006, ble planen presentert som forankret i en rekke kunnskapsoppbyggende prosesser: «forskning, kartlegging, miljøovervåking, annen datainnhenting og rapportering innenfor mange sektorer og institusjoner» (St.meld. nr. 8 (2005-2006), s. 101). Også når den første forvaltningsplanen ble revidert i 2011, het det at «planen bygger på den styrking av kunnskapsgrunnlaget som har skjedd siden 2006 (Meld. St. 10 (2010-2011), s. 6). Styrkingen av kunnskapsgrunnlaget i perioden etter 2001 har også blitt vektlagt av Stortinget.

Kort oppsummert kan vi si at prosessen med forvaltningsplanene var viktig for Stortingets vurdering av kunnskapsusikkerheten knyttet til miljøkonsekvensene av petroleumsvirksomheten. Mens situasjonen i 2001 var usikker nok til at man innførte midlertidig boreforbud og la ekstra begrensninger på petroleumsvirksomheten i store deler av den nordlige sokkelen, brukte regjeringen og Stortinget kunnskapen i forvaltningsplanene for å tillate petroleumsaktivitet i noen områder og ha restriksjoner i andre områder (se Andersen, 2017, kap. 8 og 9). Prosessene knyttet til forvaltningsplanene hadde altså uomtvistelige politiske konsekvenser. Og endringene i politikken ble eksplisitt forankret i endringer i kunnskapsgrunnlaget. 
Figur 1 illustrerer tydelig at prosessen minner mer om det man vil tenke på som et utredningsarbeid enn det man gjerne vil forbinde med et typisk forskningsprosjekt. Betyr dette at det i mindre grad tilfredsstiller kravene til vitenskapelighet? Hvordan kunne eller burde prosessen vært organisert? Slike spørsmål impliserer at det finnes noen måter å organisere forskningen på som er bedre enn andre; «forskning» er bedre enn «utredning». Slike vurderinger bør begrunnes, og helst med eksplisitte kriterier. Innenfor vitenskapsteorien finnes en rekke forsøk på etablere slike kriterier. Prinsipielt sett bygger de på normative vurderingskriterier. Slike prinsipper er viktige, men de gir oss ikke et godt grunnlag for å forstå hva aktørene i feltet gjør og sier. Og det er dette jeg er særlig interessert å utforske her.

I dette kapittelet går jeg derfor ikke inn i diskusjonen om hva som egentlig kjennetegner forskning og vitenskapelighet, eller hvilke vitenskapsteoretiske kriterier som brytes eller overholdes i disse prosessene. Utgangspunktet er istedenfor en analyse av hvordan aktørene selv anvender og vurderer begreper og kriterier som «forskning», «utredning» eller «vitenskapelig». I gjennomgangen over har vi for eksempel allerede sett at prosessene med forvaltningsplanene ble definert som vitenskapelige og forskningsbaserte av de politiske aktørene. Vi har også sett at de politiske aktørene ga denne kunnskapsproduksjonen et klart formål: Den skulle bidra til å utvikle en ønsket politikk på dette området, noe som gjerne omtales som «mandated science» (Salter, 1988) eller «regulatory science» i forskningslitteraturen (Irwin, Rothstein, Yearley \& McCarthy, 1997; Jasanoff, 1995). På norsk fanger begrepet forskning for politikk opp de mest vesentlige dimensjonene. Det karakteristiske er at forskning blir ansett for å være nødvendig for å utforme politikken på et område. Denne formen for kunnskapsproduksjon spiller en viktig rolle i dagens samfunn. Som illustrert så langt betyr det at politiske begrunnelser for endret politikk ofte vil underbygges med at man har fått ny og bedre kunnskap.

I den neste delen av kapittelet skal vi se nærmere på hvordan de faglige institusjonene og involverte fagfolk vurderte og opplevde prosessen. I tillegg til analyser av dokumenter bygger denne analysen på 13 kvalitative intervjuer med ansatte ved Havforskningsinstituttet (HI) og Norsk Polarinstitutt (NP). 


\section{Konsensus og faglig uavhengighet?}

Hvordan presenterte de faglige aktørene arbeidet som ble utført? I de skriftlige oppsummeringene som definerte kunnskapsgrunnlaget for å etablere en forvaltningsplan i 2006 og revidere den i 2010, blir kunnskapsgrunnlaget fremstilt som konsensus. Ved revisjonen i 2010 ble dette eksplisitt vektlagt på pressekonferansen for lanseringen av kunnskapsgrunnlaget. Leder for prosjektet ved Norsk Polarinstitutt (NP), Bjørn Fossli Johansen, understrekte at selv om arbeidet hadde involvert over hundre personer fra 26 ulike institusjoner, var «det konsensus om rapporten, det er ingen dissenser i rapporten».3

Selv om rapporten ikke inneholdt eksplisitte dissenser, avviker denne fremstillingen betydelig fra det bildet av prosessen som ble tegnet $\mathrm{i}$ intervjuer med involverte forskere og rådgivere. I disse intervjuene kom det frem at det hadde vært og fremdeles var faglige konflikter om hvordan flere tema burde beskrives i rapporten. Mens noen av de jeg intervjuet, fortalte om aspekter ved prosessen som bare antydet at det var en forventning både fra departementene og fra deltagerne om at prosessen skulle munne ut i en felles «konsensusrapport», var det andre som var helt eksplisitte på dette:

7 HI: [Viser til et konkret møte] Det ble en litt sånn selsom opplevelse. For vi visste jo at der satt folk som gjerne ville at ting skulle være annerledes. Og allikevel så var vi alle innstilt på at det skulle bli en konsensus, Og hva måtte da ut? Intervjuer: Hvorfor var alle innstilt på at det skulle være konsensus?

7 HI: Jo, for det vi har jobbet med i disse årene, fra 2006 og fremover, har vært en konsensusrapport. Så vi kunne ikke gi opp når vi skulle levere det siste faglige grunnlaget. For hvis vi da hadde sagt «okei, dere får lov til å lage deres egne rapporter», så ville hele systemet raknet. For alt var bygd opp, hele prosessen mot at denne rapporten skulle leveres som én stor rapport.

$10 \mathrm{NP}$ : Det var [den interdepartementale] styringsgruppen som besluttet at det møtet skulle komme til ja. For de ville ha en konsensus på den krangelen, før rapporten gikk i trykken.

3 Pressekonferansen er tilgjengelig i en nett-tv løsning: http://www.regjeringen.no/nb/dep/md/ lyd_bilde/nett-tv/pressekonferanse1.html?id=600673 (sitatet er fra ca. 3:20 til 3:36 i tidslinjen). 
Intervjuer: Så du vil si at det var eksplisitt, alle visste at målet var å bli enig?

10 NP: Ja, det var et direkte oppdrag det, for alle parter. For i og med at dette er et faglig grunnlag som skal forelegges storting og regjering, og det skal være konsensus - det er oppdraget vårt å opprette konsensus - så må vi ha enighet.

Beskrivelsene fra de jeg har intervjuet om prosessen, viser at det på flere områder kun i liten grad var faglig konsensus om innholdet, og at den faglige uenigheten ikke fremkom i kunnskapsoppsummeringen.

Hvordan var det mulig å komme frem til denne typen «tvungen konsensus»? Et vesentlig moment i så måte er den institusjonelle autonomien til de involverte institusjonene. De fleste av disse - inklusiv forskningsrettede institusjoner som Norsk Polarinstitutt og Havforskningsinstituttet - er deler av sentralforvaltningen. Senere i kapitlet vil vi komme nærmere inn på organiseringen av dem. Det vesentlige her er at disse institusjonene kan bli pålagt spesifikke oppgaver og bli bedt om å gi faglige råd i pågående politiske prosesser. Intervjuene med forskerne som var involvert i forvaltningsplanprosessen, samt analyser av tilsvarende prosesser antyder at dette ofte kan føre til spenninger mellom den oppgaven som forskningsinstitusjon er blitt pålagt fra overliggende departement, og den enkelte forskerens mulighet for aktivt å gi uttrykk for sin faglige vurdering.

At kunnskapsoppsummeringen til forvaltningsplanene kunne bli presentert som «konsensus» på en pressekonferanse, er et godt eksempel på dette. I denne situasjonen var rollen til NP og HI først og fremst å bidra til å produsere et faglig grunnlag for den videre politiske prosessen. Det innebærer også at muligheten til at enkeltforskere kan fremme sine egne faglige vurderinger, blir begrenset, fordi det gjør det svært vanskelig å oppnå konsensus.

Intervjumaterialet med de ansatte på HI og NP antyder at prosessen med å skrive en faglig forsvarlig oppsummeringsrapport, samtidig som man skulle oppnå konsensus, var det de opplevde som mest problematisk med forvaltningsplanprosessen. Det er i denne prosessen spenningen mellom meningene de involverte forskerne og rådgiverne har som fagpersoner, og den posisjonen og rollen HI og NP som statlige etater er forventet å innta, i størst grad kommer til uttrykk. Det ser også ut til at det er her arbeidet med forvaltningsplanen avviker mest fra en faglig 
eller vitenskapelig prosess. Flere av informantene omtaler enkelte av prosessene i forvaltningsplanarbeidet som et «spill». Tydeligst er dette hos de av informantene som eksplisitt betegner spillerne som «oljesiden» og «miljøsiden». På spørsmål om hvorfor de brukte disse begrepene, ble det vist både til prosessen med å avgjøre hvilke underrapporter som burde bli laget, og til prosessen med å skrive sluttrapportene.

6 NP: Hvis du ser på hvem som deltar her, så er jo det forvaltningsinstitusjoner og sektordepartementer som dominerer. Og de har jo alle sammen en blanding av sektorinteresser og forvaltningsansvar, i mer eller mindre grad, innenfor den sektoren. Og forskning og fagkompetanse. Sånn at å skille snørr og bart, hva som er fag og hva som er politikk, det er ikke alltid like enkelt. Så du finner jo sterke elementer av begge deler. Men jeg vil vel i rettferdighetens navn si at det har vært mest, mest faglig.

Sitatet illustrerer også hvordan informantene ofte trakk et skille mellom «faglig» og «vitenskapelig» i omtalen av de ulike delene av arbeidet med forvaltningsplanen. I noen sammenhenger brukes begrepene synonymt, i andre tilfeller knyttes betegnelsen «vitenskapelig» til det som har gjennomgått, eller er basert på, en fagfellevurdert publiseringsprosess. Intervjuene kan tolkes slik at forholdet mellom faglige og vitenskapelige vurderinger er et gradsspørsmål, og at situasjonen ofte krever at man er pragmatisk. For eksempel uttrykte én informant at de måtte «bruke fagrapporter der vi ikke har vitenskapelige publikasjoner» (1, NP). I en samtale om hvordan instituttet generelt sett arbeidet, ble sagt at gjengivelsen av kunnskapen i rådgivning noen ganger var «bare seksti prosent korrekt», men at det likevel kunne være viktig fordi «det hjelper jo på en måte å skape en forståelse hos politikerne» (12, NP). Selv om rådene man gav, ikke alltid var formulert med vitenskapelig presisjon, var altså perspektivet at man noen ganger måtte forenkle for å få frem budskapet til beslutningstagerne.

Hovedinntrykket fra hele materialet er at kriteriet intervjuobjektene anvendte når de omtalte eller vurderte idealet for forvaltningsplanprosessen, var at det var den «beste» kunnskapen som burde legges grunn for de rådene som ble gitt. Den kunnskapen som var «best», var den som var mest «vitenskapelig», og idealet var veletablerte fakta understøttet av flere 
fagfellevurderte publikasjoner. Dette ble satt i kontrast til råd som hvilte på meningene eller vurderingene til enkeltpersoner, og til vurderinger som ikke var basert på flere fagfellevurderte publikasjoner. De ansatte ved disse instituttene beskriver det altså som sin arbeidsoppgave å medvirke til en mest mulig vitenskapelig underbyggelse av forvaltningsplanen. Når forvaltningsplanen likevel «bare» blir karakterisert som «faglig» i mange av intervjuene, er det fordi den også tar i bruk upubliserte data, fordi den er forankret i hvordan disse tolkes hos enkelte involverte aktører heller enn i etablerte og fagfellevurderte analyser, og fordi oppsummeringsrapportene bærer preg av forhandlinger om hvordan kunnskapsstatus skal beskrives. Enkelte av de involverte knytter denne vurderingen eksplisitt til deres oppfatning av at en rekke ikke-vitenskapelige hensyn også påvirket prosessen, slik det er illustrert i sitatet med 6 NP over.

At forskningsbasert rådgivning blir presentert som mer formalisert på en offentlig pressekonferanse enn i personlige intervjuer, samsvarer for øvrig med andre studier av denne typen prosesser (se diskusjon og referanser til denne litteraturen i Sundqvist, Bohlin, Hermansen \& Yearley, 2015). Dette kan forstås som uttrykk for at involverte aktører - både forskere, rådgivere og politikere - føler at denne typen prosesser må tilfredsstille noen idealer for vitenskapelighet for å være legitime i en bred offentlighet. Det er altså ikke særlig spesielt at faglig uenighet blir underkommunisert i en slik prosess.

Det spesielle i denne sammenheng er at enigheten skapes og forankres gjennom en særskilt organisering av prosessen. «Alle» visste at man måtte forhandle seg frem til et sluttresultat som ble levert til riktig tid og som kunne aksepteres av de involverte institusjonene. Selv om enkeltpersonene ikke var enige seg imellom, ser det ut til at forpliktelsen til instituttene de var ansatt ved, medførte at de måtte akseptere skriftlige fremstillinger som de var uenige i. Behovet for å skape konsensus ble slik en viktig del av rådighetsrommet som var tilgjengelig i selve skriveprosessen.

At konsensus var viktig, fremstår derfor som sentralt for å forstå forskningens betydning og begrensning for arbeidet med å lage forvaltningsplanen. For det første kan det forstås som relatert til den politiske målsettingen om at prosessen skulle føre til bedre «koordinering mellom sektorer» samt gi et felles kunnskapsgrunnlag. Dette ser igjen ut til å være 
krav til prosessen som de involverte forskerne og rådgiverne opplevde at departementet eller det politiske feltet stilte til de involverte instituttene og etatene. Et krav om konsensus bidrar ikke bare til å forme hvilken representasjon av prosessen det er nødvendig å gi til offentligheten. Det setter også noen rammer for hva slags kritikk som må tas internt, og når i prosessen det er rom for kritikk. Dette kan føre til et spenningsforhold mellom den enkelte ansattes vurdering av rapporten og dens innhold, og hva de involverte instituttene kan si og mene om «konsensusrapportene».

9 NP: Alle etatene som har vært med på å skrive rapporten, skal levere en høringsuttalelse, og det er noe som enkelte kanskje fortsatt stiller spørsmål ved. Og da er det at man tar på seg hatten til institusjonen. Altså, man har jo hatt noenlunde fred i forkant. For det er jo litt viktig, når vi har en rapport med konsensus som disse forskjellige direktoratene har vært med på, så er det jo litt viktig at vi i hvert fall ikke går ut og sier at alt som står der er feil, for å sette det på spissen. [...] Det bør vi ikke gjøre, for den diskusjonen bør vi ha tatt i forkant.

Noen av de som hadde deltatt $\mathrm{i}$ arbeidet med det skriftlige sluttresultatet, ga også konkrete eksempler på deler av sluttrapporten som de mente var sterkt påvirket av forhandlinger mellom de involverte i selve skriveprosessen. Et av de konkrete eksemplene jeg ble gitt, var fra en ansatt ved NP som påpekte at beskrivelsen av oljevernberedskapen ofte var et konflikttema, og at «oljesiden» ofte hadde sterke meninger om hvordan denne ble beskrevet. Konklusjonen til denne informanten var at «man vil nok ikke få inn realiteten i en sånn rapport». Poenget var at dette var et så viktig tema for «oljesiden», at presise beskrivelser av når oljevernutstyret virket og ikke virket, ble omskrevet til et litt ullent språk. De færreste jeg intervjuet, var så tydelige som dette i sin kritikk av prosessen. Når slike tema ble berørt, ble kritikken mer forsiktig formulert, og de jeg intervjuet, understreket ofte - med ulike formuleringer - at deres rolle bare var å bidra til et faglig beslutningsgrunnlag.

Informantene trakk på denne måten et skarpt skille mellom det faglige bidraget fra HI og NP og de delene av prosessen som de anså som politiske: «Det eneste vi kan gjøre, er å si: 'Dette vet vi, dette er konsekvensene, dette er usikkerhetene.' Og så er jo rollefordelingen i samfunnet sånn at da er det politikerne som tar beslutningen» $(1, \mathrm{HI})$. 
Sitatet illustrerer hvordan mange av informantene i sine refleksjoner over prosessen ofte påpekte at kunnskapsprosessene var del av en større politisk og demokratisk prosess. Enkelte av utsagnene kan tolkes som uttrykk for at det er begrenset hvor sterke faglige føringer som $b ø r$ legges på et slikt dokument, fordi dokumentet er en viktig del av en politisk prosess. Det paradoksale er at de politiske aktørene definerer kunnskapsoppsummeringen som et faglig og vitenskapelig dokument. I de politiske dokumentene fremstår kunnskapsoppsummeringen som objektiv, mens de faglig ansvarlige i intervjuene vektlegger rapportens politiske relevans. At rapportens betydning er fleksibel på denne måten, er nettopp et tegn på at den er sammenvevd av både faglige og politiske hensyn, at den er samprodusert. Rapporten kan slik forstås som et potensielt vellykket grenseobjekt, hvor faglige og politiske hensyn er sammenvevd på måter som gjør det vanskelig å definere hva som er rent faglig og hva som er rent politisk, og hvor de ulike aktørene derfor finner grunnlag for å definere betydningen av rapporten på ulike måter (Bowker \& Star, 1999; Star \& Griesemer, 1989).

Intervjuene illustrerer også at prosessen innebærer et visst krysspress mellom vitenskapelig objektivitet og politisk relevans for ansatte i denne typen forskningsinstitutter. For den enkelte forsker eller rådgiver kan den faglige eller akademiske friheten bli underlagt den rollen HI og NP har som direktorater. Hvor problematisk dette oppleves, varierer sannsynligvis mye mellom ulike prosesser. Arbeidet med forvaltningsplanen berørte sterke nærings- og samfunnsinteresser, og det er tydelig at informantene er oppmerksom på at vurderingene deres kan få politiske konsekvenser. Saken står dessuten høyt på dagsordenen og har massemedias interesse, slik at utsagn fra personer som deltar i prosessen, vil kunne få betydelig oppmerksomhet. På den annen side setter idealet om objektivitet og vitenskapelighet noen grenser for hvordan politisk innflytelse på den faglige prosessen kan utøves. Fordi det er en forutsetning for politisk relevans at kunnskapen kan defineres som objektiv, har ansatte i direktoratsektoren og institutter som HI og NP et maktpotensial. Det vil være rimelig å forvente at det vil få politiske implikasjoner dersom involverte forskere offentlig kritiserer en slik prosess som uvitenskapelig eller preget av politisk overstyring. 
Flere av beskrivelsene av prosessen som ble gitt til meg i intervjuene, synes å bryte ganske klart med den politiske forventingen om et best mulig og politisk nøytralt kunnskapsgrunnlag.

Derfor er det relevant å spørre om hvorfor en slik kritikk ikke ble fremmet i den offentlige debatten. Flere aspekter ved organiseringen synes å være vesentlig for å forstå dette. For det første ville en slik kritikk av hele prosessen delvis også ha vært en selvkritikk. HI og NP har jo selv vært med å legge frem disse rapportene, og de involverte står som forfattere av de dokumentene de da skal kritisere. For det andre ville en slik kritikk, fremført i offentligheten og kanskje særlig i massemedia, vært et brudd med det vertikale statlige hierarkiet som HI og NP er en del av. For enkeltforskere innebærer det kanskje også at man setter egen karriere på spill om man skal gå ut med en slik kritikk, særlig dersom det blir gjort uten oppslutning fra ledelsen ved instituttet. Inntrykket fra intervjuene er at den øverste ledelsen ved instituttene ofte har tett kontakt med departementet samt innsikt i hvilke politiske implikasjoner instituttets rådgivning kan få. For det tredje er prosessene organisert slik at det er en rekke «sikkerhetsventiler» for faglig kritikk, så lenge den skjer på riktig tid og sted. HI og NP kan uttale seg om saken, og de gjør det - både i formelle prosesser og i massemedia. Det at de kan avgi høringsuttalelser til den rapporten de har vært med på å skrive, kan forstås som en slik sikkerhetsventil, hvor faglige kontroverser kan bli kommunisert på en akseptabel måte. Et fjerde poeng er at mange av de spørsmålene hvor instituttene blir bedt om å komme med råd, bærer preg av å være både faglige og politiske. Spørsmålene som skal besvares, er i den forstand hybride og kan ofte vanskelig besvares på en måte som tilfredsstiller krav til vurderinger i fagfellevurderte publikasjoner. Det å «gå høyt på banen» vil således ofte innebære at man inntar et standpunkt i et normativt spørsmål som ikke lar seg begrunne faglig, eksempelvis hvor man $b ø r$ tillate en næringsvirksomhet. Å aktivt formidle synspunkter på slike spørsmål i en offentlig debatt kan således bli definert som å innta en politisk posisjon fremfor «bare» å formidle en vitenskapelig fundert vurdering. I så fall står både enkeltforskere og instituttene de arbeider ved, i fare for ikke lenger å bli forstått som vitenskapelige aktører, og de kan slik bli mindre relevante for den politiske prosessen. Et interessant aspekt er således at 
nettopp instituttenes hybride karakter kan begrense mulighetene de har for å komme med en faglig fundert kritikk i offentlige debatter. Samtidig kan det at de er tett knyttet til de politiske prosessene, gi dem mulighet til å påvirke politiske prosesser utenom det offentlige ordskiftet eller i offisiell kommunikasjon (som i brev eller dokumenter), eksempelvis gjennom personlig kontakt med politisk og faglig ledelse i departementene.

\section{Direktoratsektoren - en glemt forskningssektor?}

Analysen så langt viser at når man skal gripe forskningens betydning og begrensning for politiske prosesser, er det viktig å forstå den typen forskningsinstitusjoner som HI og NP representerer. NP og HI er både forskningsinstitutter og en del av den sentrale statsforvaltningen. I sistnevnte funksjon er de formelt sett å regne som fagdirektorater. De fleste direktorater vil ha som rolle å gi faglige råd til departementene. Utformingen av politikken på et område skjer imidlertid primært i departementene, som igjen har en politisk ledelse forankret i regjeringen. Direktoratene har på sin side ikke en politisk valgt ledelse som utgår fra regjeringen, og er heller ikke å regne som politiske organer slik som departementene. Likevel er de underlagt departementer og kan bli instruert av disse. Direktoratene er således formelt sett en del av det byråkratiske hierarkiet. NP er underlagt Miljøverndepartementet, mens Havforskningsinstituttet er underlagt Nærings- og fiskeridepartementet.

Både NP og HI har noen få forvaltningsoppgaver, men innenfor arbeidsområdene deres ivaretas dette primært av henholdsvis Miljødirektoratet og Fiskeridirektoratet. NP og HI har forskning og rådgiving som sin primære oppgave. De er faginstanser på sine områder for andre deler av forvaltningen og departementene. Det som bidrar til å gjøre HI og NP til noe annet enn hva man vanligvis forbinder med en statlig etat, er at de driver en omfattende forskningsvirksomhet, og at rundt en tredel av de ansatte har vitenskapelige stillinger. ${ }^{4}$ Instituttene gjør mer enn å gi

4 Med vitenskapelige stillinger mener her stillingskategoriene forsker (med underkategorier), postdoktor, stipendiat og vitenskapelig assistent. 
råd i form av rapporter, de har også en ganske høy vitenskapelig produksjon. I omfang publiserer de like mye som de største grunnenhetene ved universitetene i Norge. HI og NP får rundt 50-60 \% av inntektene sine direkte over statsbudsjettet. Som for universitetene blir disse midlene gitt sammen med et tildelingsbrev som gir overordnede føringer for hva departementet forventer at instituttet skal utføre i det kommende året. De resterende inntektene kommer i form av ekstern forskningsfinansiering, hovedsakelig fra det norske forskningsrådet og EU, samt betalte rådgivningsoppdrag. I forskningspolitisk sammenheng blir instituttene omtalt som «forvaltningsinstitutter», og de er kategorisert som en del av den norske instituttsektoren (Meld. St. nr. 18 (2012-2013)). I den siste forskingsmeldingen begrunner Nærings- og fiskeridepartementet rollen til Havforskningsinstituttet med det «omfattende og kontinuerlige behov for vitenskapelig rådgiving» (ibid.: 135). Det er typisk for slike dokumenter at $\mathrm{HI}$ og NP ikke presenteres som direktorater, men som vitenskapelige forskningsinstitutter. Også i instituttenes egenpresentasjoner brukes som hovedregel betegnelsen «forskningsinstitutt» og andre formuleringer som vektlegger det vitenskapelige arbeidet de gjør.

Det er således problematisk å klassifisere HI og NP som enten en del av forskningssektoren eller som forvaltningsorgan som er underlagt sitt sektordepartement. Inntrykket er heller at instituttene er begge deler, og at en eventuell grenseoppgang mellom forskning og rådgivning går internt $\mathrm{i}$ instituttene. Dette er ikke unikt for disse to instituttene; det er tvert imot et ganske vanlig trekk ved en lang rekke forskningsinstitutter med bånd til et sektordepartement. Blant de med flest forskningsårsverk (i parentes) finner vi Forsvarets forskningsinstitutt (500), Havforskningsinstituttet (600), Nasjonalt folkehelseinstitutt (500), NIBIO (500), Norsk Polarinstitutt (200), SSB (200) og Veterinærinstituttet (200) (NIFU, 2017). Det finnes altså en rekke forskningsinstitutter i Norge med en formell tilknytning til et departement. De er ofte viktige kunnskapsprodusenter på sine felt, og samlet har de minst like mange vitenskapelige ansatte som et stort norsk universitet. Disse instituttene skiller seg fra universitets- og høyskolesektoren som er gitt ansvaret for statlig finansiert undervisning og forskning, hvor blant annet retten til akademisk frihet er lovfestet i universitets- og høyskoleloven (2005: $\$ 1-5)$. De skiller seg også fra den 
delen av instituttsektoren som ikke har en formell binding til det statlige hierarkiet, som typisk er organisert som stiftelser eller aksjeselskap. De formelle bindingene til departementene gir grunnlag for å definere dette som en egen del av norsk forskningssektor - direktoratsektoren.

Direktoratsektoren generelt, og organiseringen av forvaltningsplanprosessen spesielt, kan forstås som én måte å integrere faglig-politiske spørsmål i avgjørelsesprosesser på. HI og NP er på den ene siden en del av statsbyråkratiet - og med det en hierarkisk linjeorganisasjon preget av vertikalfordelt autoritet, der de ansatte er tjenestemenn. På den andre siden er de tildelt rollen som fagekspertise som både skal produsere og oppsummere faglige innsikter i rådgivningsprosesser. Slik representerer de også en faglig ekspertise som skal være uavhengig av den politiske prosessen. Den dobbeltrollen disse forskningsinstituttene har, bidrar til en «rolleflertydighet» (Jacobsen, 1960) som gir fleksibilitet i relasjonen mellom «ren faglig vurdering» og «politikk».

De jeg intervjuet ved HI og NP, synes primært å gi uttrykk for at de har, eller bør ha, akademisk frihet. Dette er en fremstilling som de fleste av intervjuobjektene gjorde gjeldende, selv om analysen av forvaltningsplanprosessene tydelig viser at enkelte, særlig de som er involvert som rådgivere, også er klar over at de er forventet å bidra konstruktivt til den politiske prosessen.

\section{Avsluttende drøfting}

Den omfattende litteraturen om hvordan faglige og politiske hensyn blir vevet sammen, er tydelig på at arenaer for sammenveving kreves for å transformere vitenskapelige innsikter til politisk relevant kunnskap. Således blir de både nødvendige og viktige for politiske prosesser i moderne samfunn (Sundqvist et al., 2015). Analysen i dette kapittelet har antydet at direktoratsektoren er viktig for sammenvevingen av kunnskap og politikk på miljøfeltet i Norge. Imidlertid ser vi også (se også Andersen 2017) at den faglige autonomien til direktoratsektoren er avgrenset. Heller enn direkte politisk innflytelse på hva de skal mene i faglige spørsmål, er autonomien begrenset gjennom politiske forventinger til hva slags faglige 
råd man trenger, til at rådene må ha politisk relevans (kunne gjennomføres), og til at de skal bidra «konstruktivt» til den politiske prosessen.

Utfordrer konsensuskravet den faglige uavhengigheten i direktoratsektoren? Dersom utgangspunktet er at forskning og politikk kan - og bør - være adskilte sfærer, er svaret utvilsomt ja. Som vist i analysen kan mangelen på autonomi bidra til å forme fremstillingen av det faglige beslutningsgrunnlaget og dermed også politiske debatter. For eksempel kunne forvaltningsplanene kanskje fått en annen utforming dersom den faglige uenigheten kom tydeligere frem. Og det ville igjen kunnet påvirke reguleringen av petroleums- og annen næringsaktivitet i disse havområdene. Således er det gode grunner til å ha et kritisk blikk på hvordan denne typen prosesser fungerer.

Samtidig er det en omfattende og mangfoldig litteratur som viser at relasjonen mellom forskning og politikkutforming sjeldent er, og som hovedregel ikke kan være, enveis og klart adskilt. Dette gjør det etter mitt syn mindre fruktbart med en diskusjon som kun handler om hvordan fag og politikk kan separeres. Jeg mener man heller bør ta utgangspunkt i at sammenveving kan skje på mange ulike måter, og at ulike relasjoner vil ha konsekvenser - både for de politiske og de vitenskapelige dimensjonene ved slike prosesser. Argumentet er således at det viktige er å diskutere hvordan forskning for politikk kan - og bør - organiseres. Denne analysen har helt klart vist flere problematiske dimensjoner ved organiseringen slik den er i dag. Fremfor å argumentere for økt autonomi for forskningen mener jeg vi trenger en debatt som tar utgangspunkt i at sammenveving både er nødvendig og viktig, men også potensielt problematisk. Avslutningsvis vil jeg løfte frem noen av aspektene som jeg mener det er særlig viktig å være oppmerksom på.

Organiseringen i direktoratsektoren er problematisk fordi den gir stor grad av fleksibilitet angående hva som defineres som vitenskapelig. Dette er illustrert i analysen gjennom at fagfolkene definerer en rapport som politisk, mens politiske aktører definerer den samme rapporten som vitenskapelig. Den hybride karakteren til direktoratsektoren gir også fleksibilitet i hvordan disse forskningsinstituttene kan defineres. I noen sammenhenger blir institutter i direktoratsektoren primært definert gjennom hvilket sektordepartement de tilhører. Da blir gjerne de faglige 
rådene betraktet som tett knyttet til sektorens interesser, og gitt liten epistemisk autoritet. Andre ganger blir (det samme) instituttet i direktoratsektoren definert som det fremste fagligmiljøet, og som et institutt man bør lytte til. Hvor godt de faglige rådene passer med det politiske handlingsalternativet man ønsker å gjennomføre, kan noen ganger være avgjørende for hvordan instituttene i direktoratsektoren blir fremstilt. Den offentlige samtalen er ikke tjent med en slik fleksibilitet. Ofte vil det ikke komme klart nok frem at det finnes ulike faglige perspektiver på politiske problemstillinger, og det vil være uklart hva som er de faglige og hva som er de politiske dimensjonene ved problemet.

Et annet problem kommer til syne dersom vi ser for oss at forskningen kan ha ulike roller i politiske prosesser. Den kan spille en konstruktiv rolle, ved å løse politiske konflikter og peke på politiske handlingsalternativer. Den kan spille en kritisk rolle, ved å undersøke uheldige konsekvenser av politikk eller løfte frem oversette eller nye spørsmål. Og mellom disse to kan det være mellomposisjoner. Diskusjonen om hvilken rolle forskningen bør ha, forutsetter gjerne at forskerne selv kan velge sin rolle (eksempelvis som hos Pielke, 2007). Analyser av hvordan miljøforskningen blir integrert i politiske beslutningsprosesser, tegner imidlertid et annet bilde (Andersen, 2017: særlig kap. 9). Forskere og forskningsinstitutter blir ofte tildelt roller i slike prosesser, og forskernes mulighet til å velge roller er begrenset. Begrensingene skyldes dels måten forskningsprosessene er organisert på, men ikke sjelden blir det stilt eksplisitte krav til kunnskapen som skal leveres. Et godt eksempel her er kravet om faglig konsensus. Forskere og forskningsinstitutter kan motarbeide slike prosesser, men i direktoratsektoren er det å levere den kunnskapen som er etterspurt, ansett som en «en del av jobben».

Fordelen med en stor og ressurssterk direktoratsektor er at dette muliggjør ressurseffektiv produksjon av politisk relevant kunnskap. Dette er viktig for de politiske prosessene og sikrer et system som både evner å ta opp i seg faglige innsikter og som er beslutningsdyktig. Noen av ulempene er redusert faglig autonomi både for institutter og enkeltforskere, begrensninger på fagmiljøenes rolle i den brede offentlige debatten, og at det noen ganger kan være uklart hvorvidt det som blir fremstilt som en faglig vurdering, også er preget av politiske hensyn. Videre er det viktig 
å huske på at direktoratsektoren er relativt omfattende, med flere tusen forskerårsverk samlet, og at det på en del områder i liten grad finnes alternative fagmiljøer i Norge. Direktoratsektoren har en stabil tilgang til ressurser som sikrer en solid forskningsinfrastruktur og verdifulle dataserier. Dette er verdifullt for de analysene som gjøres, men bidrar også til at det er vanskelig å mobilisere motekspertise. Selv om instituttene i direktoratsektorene er spesielle gjennom sin formelle tilknytning til departementene, vil mange av de problemstillingene som er løftet frem her, angå forskernes roller i politiske prosesser mer generelt.

Det finnes ikke enkle svar på hvordan forskning best kan integreres i politiske beslutningsprosesser. Bør for eksempel rollen som kunnskapsprodusent skilles fra rollen som rådgiver? Bør departementene ha egne analyseavdelinger? Bør direktorsektoren få større autonomi? Og hvordan kan dette best sikres? Heller enn å satse på kun én rett løsning bør man veie ulike hensyn mot hverandre. Første steg vil være å få til en bred offentlig debatt om hva som kjennetegner dagens organisering, og hvilke fordeler og ulemper den gir. Denne artikkelen har forhåpentligvis gitt noen sporer til en slik debatt.

\section{Referanser}

[Anon] (2006a). Mandat for Forum for samarbeid om risiko knyttet til akutt forurensning i Barentshavet og havområdene utenfor Lofoten (Risikogruppen). Brev uten avsender publisert på nettsidene til Norsk Polarinstitutt. Datert 28. september 2006. Hentet 21. november 2018 fra www.npolar.no/npcms/export/ sites/np/no/arktis/barentshavet/forvaltningsplan/filer/RisikogruppenMandat. pdf

[Anon] (2006b). Mandat for Forum for økosystembasert forvaltning av Barentshavet og havområdene utenfor Lofoten (Faglig forum): Brev uten avsender publisert på nettsidene til Norsk Polarinstitutt. Datert 28. september 2006. Hentet 21. november 2018 fra www.npolar.no/npcms/export/sites/np/no/arktis/ barentshavet/forvaltningsplan/filer/FagligForumMandat.pdf

Andersen, G. (2017). Parlamentets natur. Utviklingen av en legitim miljø- og petroleumspolitikk (1945-2013). Oslo: Universitetsforlaget. http://dx.doi. org.10.18261/9788215028132-2017

Bowker, G.C., \& Star, S.L. (1999). Sorting things out: classification and its consequences. Cambridge: The MIT Press. 
Douglas, H. (2009). Science, policy, and the value-free ideal. Pittsburgh: University of Pittsburgh Press.

Haukli, B. (2000, 14.11). Havforskere frykter fiskekrise. Verdens Gang, s. 17.

Irwin, A., Rothstein, H., Yearley, S., \& McCarthy, E. (1997). Regulatory science Towards a sociological framework. Futures, 29(1), 17-31. http://dx.doi.org/10.1016/ Soo16-3287(96)00063-8

Jacobsen, K.D. (1960). Lojalitet, nøytralitet og faglig uavhengighet i sentraladministrasjonen. Tidsskrift for samfunnsforskning, 4 (231-248).

Jasanoff, S. (1995). Procedural Choices in Regulatory Science. Technology in Society, $17(3), 279-293$.

Meier, S., Andersen, T., Hasselberg, L., Kjesbu, S., Klungsøyr, J., \& Svardal, A. (2002). Hormonal effects of $C_{4}-C_{7}$ alkylphenols on cod (Gadus morhua). Institute of Marine Research, Bergen, Norway. Bergen: Havforskningsinstituttet. Hentet 21. november $2018 \mathrm{fra} \mathrm{http://www.imr.no/filarkiv/2003/12/SRJEPTLTFFSXXC.}$ pdf/nb-no

Meld. St. nr. 10 (2010-2011). Oppdatering av forvaltningsplanen for det marine miljø i Barentshavet og havområdene utenfor Lofoten: Tilråding fra Miljøverndepartementet av 11. mars 2011. (Regjeringen Stoltenberg II). Oslo: Miljøverndepartementet.

Meld. St. nr. 18 (2012-2013). Lange linjer - kunnskap gir muligheter: Tilråding fra Kunnskapsdepartementet 8. mars 2013. (Regjeringen Stoltenberg II). Oslo: Kunnskapsdepartementet.

NIFU (2017). Instituttkatalogen (oktober 2017). Oslo: Nordisk institutt for studier av innovasjon, forskning og utdanning. Hentet 27. april 2018 fra http://www.nifu.no/ publikasjoner/instituttkatalogen/

Norsk Polarinstitutt (2015). Bakgrunn og dokumentasjon for forvaltningsplan for Barentshavet. Hentet 27. april 2018 fra http://www.npolar.no/no/arktis/ barentshavet/forvaltningsplan/forvaltningsplan-barentshavet.html

Pielke, R.A. (2007). The honest broker: making sense of science in policy and politics. Cambridge: Cambridge University Press.

Regjeringen Stoltenberg I (2001). Miljøvernministeren stanser prøveboring utenfor Røst (pressemelding, 29.08.2001). Oslo: Miljøverndepartementet.

Salter, L. (1988). Mandated science: science and scientists in the making of standards. Dordrecht: Kluwer Academic Publishers.

SFT (2001). Petroleumsvirksomhet i Barentshavet. Brev fra Statens forurensingstilsyn til Miljøverndepartementet, datert o8-o8-01, ref::2001/1223-1. Oslo: Statens Forurensingstilsyn.

St.meld. nr. 8 (2005-2006). Helhetlig forvaltning av det marine miljø $i$ Barentshavet og havområdene utenfor Lofoten (forvaltningsplan). Tilråding fra Miljøverndepartementet av 31. mars 2006. Oslo: Miljøverndepartementet. 
St.meld. nr. 12 (2001-2002). Rent og rikt hav. Tilråding fra Miljøverndepartementet av 15. mars 2002, godkjent $i$ statsråd samme dag. (Regjeringen Bondevik II). Oslo: Miljøverndepartementet.

Star, S.L., \& Griesemer, J.R. (1989). Institutional Ecology, 'Translations' and Boundary Objects: Amateurs and Professionals in Berkeley's Museum of Vertebrate Zoology, 1907-39. Social Studies of Science, 19(3), 387-420. http:// dx.doi.org/10.1177/030631289019003001

Sundqvist, G., Bohlin, I., Hermansen, E.A.T., \& Yearley, S. (2015). Formalization and separation: A systematic basis for interpreting approaches to summarizing science for climate policy. Social Studies of Science, 45(3), 416-440. http://dx.doi. org/10.1177/0306312715583737

Universitets- og høyskoleloven (2005). Lov om universiteter og høyskoler. 



\title{
$\varnothing \mathrm{kt}$ legitimitet til konsekvensutredninger $\mathrm{i}$ Norge - Kan økt bevissthet om organisering og endrede roller styrke tilliten til ordningen?
}

\author{
Øystein Aas
}

Forskningsleder, Norsk institutt for naturforskning (NINA); professor II, NMBU, Fakultetet for miljøvitenskap og naturforvaltning

\begin{abstract}
This essay problematizes roles in environmental impact assessments (EIAs), with the Norwegian EIA regulations as the outset for discussions about trust, legitimacy and quality in EIAs. While Norwegian regulations formerly included rules for the organisation of EIA and defined clear roles for its execution, the current regulations lack definitions of roles, and instead focus on procedure and topical quality. The lack of focus on roles in EIA regulations are in stark contrast to concern for impartiality in public decision-making in general. The paper includes examples of actors assuming more than one role in an EIA process. They are for instance combining the roles of developer and expert assessor, NGO and expert assessor. I argue why this mixing of roles can weaken important objectives for EIAs, such as being participatory, transparent and credible. The Nordic countries organise the EIA processes differently. In Sweden and Denmark, regional state authorities lead and organise EIAs, while in Norway this is left to the developer. The various models provide a good basis for further discussion on how to best organise EIAs to ensure their independence and credibility. More research is needed to reveal the underlying causes of the organisational changes in Norwegian EIA, e.g. within the framework of post-normal science, asking questions not only about good or bad quality, but also the more interesting what kind of quality EIAs should possess.
\end{abstract}

Keywords: Environmental Impact Assessment (EIA), trust, legitimacy, organisation, formal roles, expertise, quality

Sitering av dette kapitlet: Aas, Ø. (2019). Økt legitimitet til konsekvensutredninger i Norge - Kan økt bevissthet om organisering og endrede roller styrke tilliten til ordningen?. I H. Ingierd, I. Bay-Larsen \& K. Hiis Hauge (Red.), Interessekonflikter i forskning (s. 177-189). Oslo: Cappelen Damm Akademisk. https://doi.org/10.23865/noasp.63.ch8

Lisens: CC BY 4.0 


\section{Innledning}

Dette kapittelet drøfter hvordan definisjonen av aktører og roller i konsekvensutredninger (KU) har endret seg over tid her i Norge, samtidig som dette holdes opp mot hvordan noen av våre naboland har organisert seg. Gjennom eksempler vil jeg vise hvordan aktør- og rolledefinisjoner (eller mangelen på sådanne) kan påvirke KU-prosesser slik at det kan reises spørsmål om uavhengighet og legitimitet. Spørsmål om aktører og roller handler dermed også om den faglige etikken i konsekvensutredningsinstituttet.

Formålet med konsekvensutredninger (KU) er å klargjøre - på et best mulig faglig grunnlag - virkningene av utbyggingstiltak for miljø, naturressurser og samfunn, og sikre at eventuell gjennomføring skjer på økonomisk og miljømessig forsvarlig vis. Slik sett kan konsekvensutredninger også karakteriseres som oppdragsforskning, der de samme kravene til forskningsetikk gjelder (Holden \& Fløtten, 2018). KU er et av de mest sentrale beslutningsverktøyene i samfunnet, og skal også bidra til enklere, åpnere og mer demokratiske plan- og utbyggingsprosesser (Tesli \& Lund-Iversen, 2014). I Norge har vi etter hvert en ganske lang historie med gjennomføring av konsekvensutredninger (se f.eks. Falkanger \& Haagensen, 1988). I flere årtier var de knyttet til sektorspesifikke lovverk, og forbindes oftest med vassdragsreguleringer, petroleumsvirksomhet og andre større utbyggingsprosjekter av nasjonal interesse. Fra og med 1990 ble KU forankret i plan- og bygningsloven, og det gjennomføres nå også KU rutinemessig knyttet til planprosesser - både overordna planer og reguleringsplaner. Opp gjennom årene har KU-regelverket gjennomgått endringer (dagens regelverk forankret i plan- og bygningsloven ble for eksempel sist revidert og harmonert med EUs regler i 2017). Videre er det høstet erfaringer og gjennomført mye forskning for å styrke KU-prosessene både internasjonalt og i Norge (se Holth \& Winge, 2014).

Norges anerkjente jurist og ekspert på forvaltningsrett og naturvernlovgivning, professor Inge Lorange Backer, sa i sin store avhandling «Naturvern og naturinngrep» fra 1986 at organiseringen av arbeidet med en konsekvensutredning reiser flere viktige spørsmål (Backer, 1986 s. 622). Noen av de sentrale organisatoriske spørsmålene som han der trakk opp, var: «Er det søkeren eller den offentlige forvaltningen som skal 178 
lede en slik utredning, og i så tilfelle hvilket forvaltningsorgan?» «Skal det benyttes fagkyndige, i tilfelle fra hvilke fagområder, og skal disse være uavhengige, eller kan det brukes fagfolk i søkerens eller forvaltningens tjeneste?» Spørsmål rundt organisering av norske konsekvensutredninger er senere blitt så godt som borte fra debatten omkring KU-regelverk og -praksis i norsk planpraksis (men se Tesli \& Lund-Iversen, 2014, og Tennøy, 2014). Enkelte spørsmål er besvart i gjeldende regelverk, men mange er det ikke.

\section{Hva innebærer «kvalitetskravet»?}

Det sentrale målet for KU-prosessene er å sikre at de holder tilstrekkelig god [faglig] kvalitet (Leknes \& Lerstang, 2003; IAIA, 2006; Forskrift om konsekvensutredninger, 2017). Som regel har dette vært drøftet med utgangpunkt i kvaliteten på innholdet i de ulike stegene i en KU-prosess, altså de mer konkrete resultatene - slik de materialiserer seg i form av meldinger, utredningsprogrammer, fagrapporter og endelige konsekvensvurderinger (Leknes \& Lerstang, 2003). Selve prosessen med melding, utredningsprogram, utredning og beslutning er nøye beskrevet i regelverket, og dessuten underlagt faglige vurderinger. Et tema som derimot i mindre grad er problematisert de siste årene, er altså hvordan de ulike aktørene organiserer seg og tar eller får roller i en KU-prosess.

Den internasjonale organisasjonen for konsekvensutredninger, International Association for Impact Assessment - IAIA, har etablert 14 hovedprinsipper som skal sikre en god og forsvarlig KU. Tre sentrale kriterier her er kravet om at en KU-prosess skal være gjennomsiktig og åpen (Transparent), den skal sikre delaktighet (Participative), og den skal være tillitsskapende (Credible). Disse er igjen nært knyttet den såkalte Århuskonvensjonens mål om at borgere skal ha tilstrekkelig tilgang til miljøinformasjon, at de skal kunne delta i planlegging, og at de skal ha tillit til at beslutninger om miljøinngrep er rettferdige (Hartley \& Wood, 2005). Hvorvidt disse kravene oppfylles, er selvsagt nært knyttet til prosessen og de deltagende aktørenes roller og oppgaver i gjennomføringen av konsekvensutredninger. 


\section{Roller i norske KU før og nå}

Et naturlig utgangspunkt for en drøfting av roller i norsk KU-praksis kan være å ta for seg de formelt definerte rollene i lovverket knyttet til energilovgivningen, i første rekke vassdragslovgivningen, og sammenligne dem med rollene i dagens generelle regler forankret i planlovverket (Aas, 2006). Dette fordi mye av den tidlige norske erfaringen med KU ble utviklet i vassdragsreguleringssaker. Konsekvensutredninger som tema kom for alvor inn i samfunnsplanleggingen når kravene om miljøhensyn økte i etterkrigstiden. Fra begynnelsen var de nært knyttet til statlige organers generelle utredningsplikt (Backer, 1986), og når det gjaldt vassdragskonsesjoner, ble kravene om konsekvensutredninger formalisert på slutten av 1960-tallet (Falkanger \& Haagensen, 1988).

Den enkle tabellen under viser de formaliserte rollene før og nå.

\begin{tabular}{|l|l|}
\hline $\begin{array}{l}\text { KU - roller i vassdragslovgivningen } \\
\text { (frem til 1990) }\end{array}$ & $\begin{array}{l}\text { KU-roller etter plan- og bygningsloven } \\
\text { (etter 1990) }\end{array}$ \\
\hline Søker & Tiltakshaver \\
\hline Myndighet & Ansvarlig myndighet \\
\hline Ekspert/utreder & Parter; interesseorganisasjoner, fagmyndigheter \\
\hline Fagmyndigheter & \\
\hline Allmenne interesser & \\
\hline
\end{tabular}

Som vi ser, er det nå færre roller og aktører som er eksplisitt definert, samtidig som det har vært viktige endringer i rolledefinisjonene før og etter 1990. For det første var det flere roller som var definert tidligere, og som ansatt i et forskningsinstitutt er det interessant å merke seg at en eksplisitt rolle som ekspert nå er helt fjernet fra regelverket.

Rollene knyttet til den gamle sektorlovgivningen ${ }^{1}$ (her vassdragslovgivningen) opererte med det sentrale myndighetsorganet i en hovedrolle. Søkeren var ansvarlig for å bekoste de utredningene den ansvarlige myndigheten fant nødvendig. Det var også etablert en praksis med en definert utreder-/ekspertrolle, som det ble tilstrebet skulle være uavhengig av søker. Et godt eksempel på dette er opprettelsen av det såkalte reguleringsteamet i Direktoratet for vilt, jakt og ferskvannsfiske (DVF) på slutten av 1960-tallet (Gunnerød, 1999). Dette var et fagteam av eksperter

1 I motsetning til sektorlovgivning kan plan- og bygningsloven anses som sektorovergripende. 
(med anerkjent vitenskapelig kompetanse), ansatt i DVF, som skulle forestå undersøkelser i regulerte eller planlagt regulerte vassdrag, finansiert av konsesjonsavgiftsfondet. Et annet fagteam ble opprettet ved de naturhistoriske museene i Oslo, Bergen og Trondheim, laboratoriene for ferskvannsøkologi og innlandsfiske. Et tredje team var det såkalte Fagutvalget for vassdragsreguleringer som på initiativ fra NVE ble opprettet ved Universitetet i Oslo. Dette teamet, som gikk under navnet Vassdragsforsk, gikk midt på 1980-tallet inn i Økoforsk. ${ }^{2}$ Disse ekspertteamene hadde dels komplementær, dels supplerende kompetanse på sentrale miljøfaglige områder som fisk og fiske, vilt, vegetasjon og flora, og etter hvert også på mer tverrfaglige temaer som friluftsliv og turisme. Poenget med denne historiske gjennomgangen er å vise hvor stor vekt som ble lagt på å sikre at beslutninger om vassdragsreguleringer ble bygd på ekspertteam forankret i uavhengige akademiske institusjoner eller hos sentrale fagmyndigheter.

I Norge er det nå kun tre formelle roller i en KU. Disse er tiltakshaver (utbygger), myndighet og parter i saken. I en samlepost, og i det en kan tolke som biroller, finner vi andre myndighetsorganer enn ansvarlig KU-myndighet og allmenne interesser. Istedenfor vektlegging av roller samt organisering av KU-prosessen, er det målsettinger om kvalitet som i første rekke skal ivaretas gjennom høring og myndighetsgodkjenning av melding, utredningsprogram og selve KU. Selv om det i de fleste KU-prosesser brukes en eller annen form for ekstern rådgiver, konsulent, utreder eller ekspert, er denne rollen altså ikke beskrevet eller blitt gjenstand for krav om kompetanse eller uavhengighet i dagens regelverk. Det er utredningsprosessen og de produktene som fremkommer der, som ifølge regelverket alene skal benyttes i vurderingen av «kvalitet i KU».

\section{Rolleblanding i norsk KU}

La oss se på noen eksempler på KU-prosesser der aktører tar flere eller uvante roller.

2 I 1988 dannet Økoforsk og Forskningsavdelingen ved DVF (som nylig hadde fått navnet Direktoratet for naturforvaltning) grunnlaget for etableringen av NINA. 


\section{Eksempel 1: Tiltakshaver (utbygger) som utreder}

I dagens Norge kan det hende at tiltakshaver selv forestår de faglige utredningene, enten med egne fagfolk eller med varierende grad av innleid ekspertise. I en del mindre saker kan dette skje både for avgrensa faglige utredninger og for hele KU, mens i større saker vil tiltakshaver kanskje ta ansvaret for syntesen av ulike fagutredninger, selve KU-en. Dette innebærer både fordeler og ulemper. Fordelene er flere. For det første kan det bidra til at utbygger ansvarliggjøres med tanke på tiltakets virkninger. For det andre vil det ofte føre til at utbygger opparbeider en viss faglig kompetanse på feltet. Ulempen er, selv med myndighetens tilsyn med KU-prosessen, at en kan mistenke utbygger for å ikke gjøre en tilstrekkelig objektiv jobb med selve konsekvensutredningen. Negative virkninger kan underslås eller bagatelliseres, og positive virkninger kan fremheves og forstørres mer enn det er grunnlag for. Dette kan altså svekke utredningens grunnleggende legitimitet, uavhengig av om det er reelt grunnlag for å kritisere den faglige kvaliteten på arbeidet som er gjort. Dette er altså en problematikk nært knyttet til habilitetsprinsippet.

\section{Eksempel 2: Representanter for parter og allmenne interesser som utreder}

Et annet, ikke uvanlig eksempel fra dagens Norge, er at frivillige organisasjoner som representerer anerkjente parter i saken (f.eks. miljøvern, kulturminnevern og/eller lokalmiljø) og allmenne interesser deltar i KU-prosessen, oftest i en slags utreder- eller ekspertrolle. Ett eksempel på dette er en ornitologisk forening som deltar i de faglige utredningene $i$ en KU om temaet virkninger for fuglelivet. Vi har i dag enkelte frivillige organisasjoner som enten ved hjelp av tillitsvalgte eller ansatte, eller gjennom «konsulentaktige» deler av en administrasjon deltar i KU-prosesser i en ekspert-/utrederrolle.

Dette medfører åpenbart visse fordeler. Det kan sikre en kostnadseffektiv bruk av aktørens detaljkunnskap i selve utredningen. Slik sett kan det også oppfattes som en arbeidsmåte som åpner opp prosessen og gi 
inntrykk av tillit. Likevel mener jeg at denne arbeidsmåten samlet sett kan skade KU-prosessen. Årsaken er at den kan skape problemer for organisasjonens videre deltagelse i prosessen. Partsrepresentanter eller ivaretagere av allmenne interesser skal ha en hovedrolle som høringsinstans gjennom hele KU-prosessen, fra tiltaket blir kjent til beslutning om gjennomføring eller ikke er fattet. Denne kan være vanskelig å utføre når en slik aktør har vært tungt inne i en rolle som utreder. Kanskje føler parten eller organisasjonen at den gjennom utredningsarbeidet har «fått sagt sitt», og ser på et slikt engasjement som en mulighet til å få økte ressurser til å få frem sin kunnskap og sitt syn på saken. Like fullt vil en slik rolle lett kunne føre til at interesser som frivillige organisasjoner forventes å ivareta, ikke ivaretas på de sentrale beslutningspunktene i en KU-prosess.

\section{Eksempel 3: Kombinert myndighets- og tiltakshaverrolle}

Den kanskje vanligste situasjonen der en aktør har flere roller, er der utbygger også er KU-myndighet, eller der det er nære bånd mellom tiltakshaver og KU-myndighet. Slike situasjoner kan oppstå når en statlig etat er utbygger, og samtidig har myndighetsfunksjoner i KU-en. Men oftest oppstår de trolig i lokale KU-prosesser, der kommunen er KU-myndighet. Utbygginger i kommunene skjer stadig oftere i et tett samarbeid mellom myndighet og privat utbygger, for eksempel gjennom utbyggingsavtaler. Hovedproblemet dette skaper, er selvsagt at en kan stille spørsmål ved hvordan kommunen evner å ivareta kontrollfunksjonen og opptre habilt når myndighetsorganet selv har interesser i utbyggingen.

\section{Krav til ekspert/utreder?}

En rekke veiledere legger til grunn at ekspertisen som brukes i KU, skal opptre på en faglig tilfredsstillende måte. Et eksempel på dette er De nasjonale forskningsetiske komiteenes retningslinjer innenfor naturvitenskap og teknologi når det gjelder oppdragsforskning. Utredere skal i 
henhold til disse være åpne om eventuelle interessekonflikter og tilstrebe de samme prinsipper for vitenskap også i utredningsarbeid, som KU er en del av. Målet om vitenskapelig kvalitet knytter seg blant annet til at utredningen skal bygge på anerkjent metodikk og oppdatert fagkunnskap, være etterprøvbar, transparent på forutsetninger samt klargjøre usikkerhet (NENT, 2016; Holden \& Fløtten, 2018).

Likevel er det omfattende forskning som påviser at KU kan ha en rekke skjevheter som - bevisst eller ubevisst - svekker kvaliteten. Tennøy et al. (2006) påviser ulike svakheter i en rekke norske KU, som deles inn i modellfeil, datafeil/feil i forutsetninger, og partiskhet. Videre gjennomgår Tennøy (2014) KU-litteraturen på feltet og drøfter nærmere årsaker til såkalt vinklede KU (beslektet med partisk KU), der utreder bevisst eller ubevisst vinkler, vrir eller manipulerer resultater og vurderinger. Videre forklares tre hovedtyper av vinkling: A) Strategisk feilaktig fremstilling som ofte handler om å velge forutsetninger som for eksempel tilslører heller enn avdekker konsekvenser, eller som fremmer positive og reduserer negative virkninger. Dette kan handle om å velge selektivt i kunnskapsgrunnlaget og på den måten komme frem til mer positive virkninger enn en mer «objektiv» og balansert bruk av foreliggende kunnskaper. B) Forvirring, skjulte forutsetninger eller underkommunisering. Her er en mye brukt taktikk å vektlegge usikkerhet. En annen er å dekke over eller ikke redegjøre for forutsetninger, modeller og data som brukes som grunnlag for analysen. I sum fører dette ofte til at KU blir vanskelig å forstå og i mindre grad vektlegges i beslutningen. C) Endre fokus vil si at en sak for eksempel bare belyses på en enkel måte og i et lokalt perspektiv, mens overordna, strategiske, langsiktige og sumvirkninger ikke analyseres.

Ståvi (2014) presenterer interessante perspektiver fra en erfaren rådgiver i Holth \& Winges (2014) antologi. Ståvi har ofte operert som utreder eller ekspert i utarbeiding av KU-er. Han legger til grunn en praksis, eller en mer uformell rolleforståelse der eksperten inntar en posisjon mellom tiltakshaver og myndighet, og argumenterer for at det først og fremst er faglig integritet og balanse i posisjonen mellom tiltakshaver og myndighet som bidrar til upartiske utredninger. Ser vi på regelverket, er det imidlertid ingen tvil om at utreder arbeider for tiltakshaver. Om myndigheten ikke finner at kvaliteten er god nok og krever tilleggsutredninger 
(jf. forskriftens $\$ 27$ ), er det tiltakshaver myndigheten går tilbake til, ikke utreder. I de (relativt sjeldne) tilfellene der det oppstår usikkerhet om kvalitet eller partiskhet, kreves det av og til at en tredjepart (dvs. ny fagutreder) skal gjøre tilleggsutredning (se for eksempel NUSSIR-saken, jf. Bjørgo \& Bay-Larsen, 2017).

\section{Kan rollene og oppgavene fordeles annerledes?}

Dagens norske KU-veiledere og KU-evalueringer preges altså i stor grad av «hvordan»- og «hvorfor»-spørsmål, og i liten grad av «hvem»-spørsmål. Andre nordiske land har definert rollene og oppgavene i KU-prosessen på andre måter enn vi i dag gjør i Norge (Bjarnadottir, 2001; Brekke \& Sataøen, 2012). I Danmark har regionale myndigheter ansvaret for å gjennomføre utredningen, på utbyggers bekostning, altså en situasjon ikke så ulik den vi tidligere hadde, men mer gjennomført og med regionalt statlig nivå som en naturlig og sentral aktør. I Sverige har også Länsstyrelsen (regional myndighet, en rolle ikke så ulik den norske Fylkesmannen) en nøkkelrolle i gjennomføringen av såkalt miljökonsekvensbeskrivning (MKB), som gjennomføres etter Miljöbalken (Sveriges helhetlige miljølov fra 1999). Her har for eksempel Länsstyrelsen mulighet for å bestemme hvilket endelig utbyggingsalternativ som tillates. Det svenske regelverket har også mer detaljerte regler om flere samråd underveis. På denne måten får man en annen rollefordeling, som igjen kan bidra til en annen prosess der både legitimitet og åpenhet styrkes. Et uavhengig myndighetsorgan styrer og gjennomfører MKB-prosessen, og eventuelle eksperter og utredere forholder seg til denne myndigheten.

Ser vi på de eksemplene som knytter seg til partiske og vinklede utredninger som er påvist over, bør det være ganske åpenbart at om utrederen jobber på oppdrag fra og under styring av myndighetene heller enn tiltakshaver, vil dette føre til flere endringer. Utreder vil unngå å komme i en (implisitt) kjøpslåingsprosess med tiltakshaver (som kanskje kan være oppdragsgiver for konsulenten ved en senere anledning, og som på denne måten - bevisst eller ubevisst - påvirker fagutreders vurderinger, først og fremst knyttet til fastsetting av forutsetninger, bruk av skjønn og kommunikasjon av usikkerhet). Det er naturlig at utreder tar tiltakshavers 
perspektiv og utgangspunkt med dagens organisering. Med en annen organisering vil perspektivet bli et annet, og da gjerne mer helhetlig. Videre er det mulig at parter og allmenne interesser lettere kan komme til orde i en prosess gjennomført av det offentlige, ikke bare som nå - i en prosess som skal kontrolleres av KU-myndigheten.

\section{Habilitet - eller hva slags prosess er egentlig en KU?}

Offentlige beslutningsprosesser i Norge har detaljerte og strenge krav til habilitet, jf. for eksempel forvaltningslovens bestemmelser. Slik jeg tolker utviklingen av norsk KU-praksis, har vi gått fra en prosess der habilitetsproblematikk har vært sentralt (jf. Backers drøfting), til en prosess der dette har mindre betydning, og der et klart skille mellom ulike roller ikke er noe krav i reglene, og i hvert fall noe aktørene ikke alltid er særlig bevisst på (Bjørgo \& Bay-Larsen, 2017). Isteden fokuserer man på å få til de rette stegene i en prosess slik de er beskrevet med oppstart og melding, utredningsprogram, KU og beslutning, der man også legger mer vekt på effektivitet og beslutningsrelevans (Arge et al., 2005).

Hva er de underliggende årsakene til den utviklingen som er beskrevet over? Kan disse utfordringene lett løses med en klar eller eventuelt økt «uavhengig» rollebevissthet (jf. Ståvi, 2014)? Etter mitt syn er det ingen grunn til at «myke» henstillinger til veiledere om å tilstrebe upartiskhet hos utbyggerstyrte konsulenter og eksperter vil være tilstrekkelig. I den videre forskningen er det derfor behov for å se nærmere på hva de store endringene som har skjedd i organiseringen av norsk KU, egentlig er uttrykk for.

Her kan man benytte flere mulige hypoteser. Er det en interesseforklaring, dvs. at gjeldende organisering er et uttrykk for at næringsinteressene har fått gjennomslag for dagens modell som følge av politisk påvirkning? Skyldes det at det norske samfunnet har en sterk tro på at faglige eksperter opptrer objektivt og uavhengig av måten vi organiserer KU på? Er det et politisk forsøk på ansvarliggjøring av nærings- og sektorinteressene gjennom at de selv må ta ansvar for kunnskapsgrunnlaget? Eller er det kombinasjoner av disse forklaringene? Mer kunnskap om 
dette er viktig for å fremme en fortsatt diskusjon om hva som er en god og hensiktsmessig organisering og rolleavklaring i norsk KU. Et interessant utgangspunkt for videre analyser kan være rammeverket for postnormal vitenskap og diskusjonen om «quality as fit for purpose», dvs. at den videre diskusjonen kanskje ikke skal handle om kvaliteten som enten god eller dårlig, men heller ta for seg det mer interessante spørsmålet om hva slags kvalitet en får. Dette er et rammeverk som blant annet er brukt til å belyse KU praksis i Nederland (Petersen, Cath, Hage, Kunseler \& van der Sluijs, 2011).

\section{Kun en syk mor?}

Som ansatt ved et forskningsinstitutt, hvis forløper ble etablert på vassdragslovens definisjon og påfølgende ekspansjon av en uavhengig fagekspertetat (se Gunnerød, 1999), tenker leseren kanskje at jeg først og fremst ønsker meg tilbake i historien - og til en veldefinert og eksplisitt ekspertrolle i KU-regelverket.

Skal vi få bedre kvalitet på og økt tillit til norsk KU, er det viktig å få mer kunnskap om hva som er årsakene til dagens organisering, og en mer nyansert diskusjon om hva vi mener med kvalitet.

På kort sikt er det behov for økt bevissthet om at det er krevende om noen aktører antar mer enn én rolle, for eksempel om representanter for allmenne interesser går inn i utrederroller. Etter min mening er det også et stort behov for å drøfte hvem som skal ha rollen som ansvarlig myndighet, særlig knyttet til om det er hensiktsmessig at kommunene har den i samme utstrekning som i dag, og om det ikke ville være riktigere om de ulike statlige sektormyndigheter som i dag godkjenner KU-prosesser på egne områder, burde avgi denne rollen enten til Kommunal- og moderniseringsdepartementet eller til Klima- og miljødepartementet, om ikke annet for å sikre harmonisering og en mer enhetlig tverrsektoriell praksis. Regelverk og kvalitetslovgivning kan i større grad stille krav til prosessuelle forhold enn det som er tilfellet i dag, og blant annet si noe om hvordan aktørene bør organisere seg samt hvilke roller og oppgaver de kan og bør ha i en KU. Et viktig mål er å unngå problematiske bindinger mellom utbyggere og fagkonsulenter - og dermed også problemet med 
vinklede KU-er - enten dette er en realitet eller kun noe dagens rammer gir et legitimt grunnlag for mistanke om (Tennøy, 2014; Bjørgo \& BayLarsen, 2017).

\section{Referanser}

Aas, Ø. (2006). Behov for økt rollebevissthet i konsekvensutredninger i Norge. I A. Tesli \& J. Thomassen (red.), Miljøinstituttenes strategiske instituttprogram om konsekvensutredninger. Sluttrapport (s. 203-212). Oslo: Miljøalliansen AS.

Arge, N., Næss, A., \& Lea, R. (2005). Nytte og ressursbruk ved konsekvensanalyser. CIVITAS Rapport.

Backer, I.L. (1986). Naturvern og naturinngrep. Oslo: Universitetsforlaget.

Bjarnadottir, H. (red.) (2001). A Comparative Study of Nordic EIA Systems. NordRegio Report 2001: 1.

Bjørgo, F., \& Bay-Larsen, I. (2017). Lost in translation - Critical reflections on the disposal of submarine tailings in Kvalsund municipality, Extr. Ind. Soc. (2017), http://dx.doi.org/10.1016/j.exis.2017.05.012

Brekke, O., \& Sataøen, H. (2012). Ekspertise, politikk eller dialog? Nettutvikling $i$ Norge, Sverige og Storbritannia. Uni Rokkansenteret Rapport 8/2012.

Falkanger, T., \& Haagensen, K. (1988). Norsk vassdragsrett. Oslo: TANO.

Forskrift om konsekvensutredninger. 2017. Hentet fra: https://lovdata.no/dokument/ SF/forskrift/2017-06-21-854

Gunnerød, T.B. (1999). NINA 10 år - et tilbakeblikk og dets forhistorie. NINA.

Hartley, N., \& Wood, C. (2005). Public participation in environmental impact Assessment - implementing the Aarhus Convention. Environmental Impact Assessment Review 25: 319-340.

Holden, L., \& Fløtten, T. (2018). Forskningsetikk for oppdragsforskning. Kommentar. De nasjonale forskningsetiske komiteene. https://www.etikkom.no/ Aktuelt/Nyheter/2018/kommentar-holden-og-flotten/

Holth, F., \& Winge, N.K. (red.) (2014). Konsekvensutredninger. Rettsregler, praksis og samfunnsvirkninger. Oslo: Universitetsforlaget.

IAIA (2006). International Association for Impact Assessment. Principles for EIA Best Practices. http://www.iaia.org/uploads/pdf/principlesEA_1.pdf (sist besøkt september 2017).

Leknes, E., \& Lerstang, T. (2003). Konsekvensutredning etter PBL. Utvikling av kvalitetskriterier. Rogalandsforskning rapport 131/2003.

Nasjonal forskningsetisk komité for naturvitenskap og teknologi (NENT) (2016).

Forskningsetiske retningslinjer for naturvitenskap og teknologi. Oslo, 2. utg. 
Lastet ned fra: https://www.etikkom.no/globalassets/documents/publikasjonersom-pdf/60124_fek_retningslinjer_nent_digital.pdf

Petersen, A.C., Cath, A., Hage, M., Kunseler, E., \& van der Sluijs, J.P. (2011). Postnormal science in practice at the Netherlands Environmental Assessment Agency. Science, Technology, \& Human Values 36, 362-388.

Ståvi, J.M. (2014). Konsekvensutredninger - erfaringer og synspunkt fra rådgiveren. I F. Holth \& N.K. Winge (red.), Konsekvensutredninger. Rettsregler, praksis og samfunnsvirkninger (s. 243-254). Oslo: Universitetsforlaget.

Tennøy, A., Kværner, J., \& Gjerstad, K.I. (2006). Uncertainty in environmental impact assessment predictions - the need for better communication and more transparency. Impact Assessment and Project Appraisal 24 (1), 45-56.

Tennøy, A. (2014). Kvalitet i konsekvensanalyser. I F. Holth \& N.K. Winge (red.), Konsekvensutredninger. Rettsregler, praksis og samfunnsvirkninger (s. 185-207). Oslo: Universitetsforlaget.

Tesli, A. (2006). Aktører, roller og ansvar i KU-arbeidet. I A. Tesli \& J. Thomassen (red.), Miljøinstituttenes strategiske instituttprogram om konsekvensutredninger. Sluttrapport. Miljøalliansen AS.

Tesli, A., \& Lund-Iversen, M. (2014). Norsk KU-historie. I F. Holth \& N.K Winge (red.), Konsekvensutredninger. Rettsregler, praksis og samfunnsvirkninger (s. 3484). Oslo: Universitetsforlaget. 



\title{
KAPITTEL 9
}

\section{Kartlegging og verdisetting av naturtyper}

\author{
Geir Gaarder og Kristin Wangen \\ Miljøfaglig Utredning
}

\begin{abstract}
Mapping of habitats is central to preserve biodiversity in Norway. This article describes the historic development of the methodology used to classify and assign value to nature types, a process that has been going on for almost ten years. A positivistic view of science has characterized the process, especially over the last few years, both among the authorities and in central specialist fora.

This article discusses several challenges related to the development of the methodology. It is especially critical of Parliament's demand for value-free methodology, which it argues is in fact impossible. Further, it discusses the need to employ expert opinion and to describe uncertainty. It also criticizes the lack of analyses that expose possible model errors of the methodology. This is especially applicable with respect to relevance and precision, where high precision in the method may increase the risk of failing to achieve the objective.

The article concludes that sufficient focus has not been placed on the challenges that appear in the intersection between natural science and practical management during the development of the new methodology for habitat mapping. This process has demonstrated the importance of broad competence, of being open about choices and acknowledging the consequences of these, and of having enough patience to develop a good methodology.
\end{abstract}

Keywords: habitat mapping, expert opinion, uncertainty, value-free

\section{Innledning}

Naturtypekartlegging er et sentralt virkemiddel for miljøforvaltningen i arbeidet med å bevare naturmangfoldet. På slutten av 1990-tallet ble det utviklet en metode for å registrere og verdisette viktige naturtyper (Direktoratet for naturforvaltning, 1999), og det har i etterkant vært

Sitering av dette kapitlet: Gaarder, G. \& Wangen, K. (2019). Kartlegging og verdisetting av naturtyper. I H. Ingierd, I. Bay-Larsen \& K. Hiis Hauge (Red.), Interessekonflikter i forskning (s. 191-214). Oslo: Cappelen Damm Akademisk. https://doi.org/10.23865/noasp.63.ch9

Lisens: CC BY 4.0 
omfattende kartlegginger basert på denne metodikken. Samtidig har systemet fått relativt tungt gjennomslag i norsk arealforvaltning. Metoden harhattennaturvitenskapeligbasisgjennomsinfokuseringpåartsmangfold og etablerte inndelingssystemer for vegetasjonstyper og tilstandsvariasjon i naturen. I tillegg har den vært forvaltningsrettet, med et verdisettingssystem basert på miljøer med bl.a. høy artsrikdom, rødlistearter og sjeldenhet. Ved bruk av dette systemet kan ethvert areal i prinsippet gis en verdi for naturmangfoldet etter en firedelt skala (svært viktig - A, viktig - B, lokalt viktig - C, eller ingen spesiell naturverdi).

En del norske politikere har vært bekymret for manglende nøytralitet i naturtypekartleggingen. I et representantforslag til Stortinget uttrykte stortingsrepresentantene Lundteigen og Arnstad (2014) blant annet sterk bekymring for at denne kartleggingen var overlatt til private aktører, og at dette «står i direkte motstrid til behovet for langsiktig oppbygging av mest mulig objektiv og verdinøytral kunnskap». Enkelte fagfolk innenfor kartleggingsmiljøene har tatt til motmæle mot deler av kritikken (Blindheim, 2015; Framstad, 2015). Dette synet på manglende objektivitet og nøytralitet har likevel preget den videre utviklingen av metoden og anvendelsen av den, senest i statsbudsjettet for 2017: «Stortinget bestemte samtidig at all naturkartlegging i alle økosystemer i Norge skal gjennomføres etter en mest mulig objektiv, verdinøytral og etterprøvbar metode» (Klima- og miljøverndepartementet, 2016). Samtidig er det lagt til at det nye kartleggingssystemet NiN (Natur i Norge), et system som nettopp baserer seg på et slikt positivistisk vitenskapssyn, skal utgjøre kjernen i dette.

Hvordan bør så ulike fagmiljøer i framtiden operere innenfor denne grensesona mellom vitenskap og forvaltning? Hva bør kartleggingsinstitusjonenes rolleforståelse og funksjon være? Og ikke minst, hvordan skal de tilfredsstille disse politiske forventningene? Erfaringer med utvikling av ny metodikk for naturtypekartlegging de siste par årene har vist at slike prosesser er svært krevende. Det har nemlig dukket opp flere viktige problemstillinger som verken fagmiljøene med naturvitenskapelig bakgrunn eller forvaltningen har virket særlig forberedt eller bevisst på. Kun i begrenset grad har det blitt stilt spørsmål ved det positivistiske vitenskapssynet, og troen på dette står tydelig sterkt innenfor både miljøforvaltningen og de ledende fagmiljøene som styrer metodeutviklingen. 
I denne artikkelen vil vi sette søkelys på noen av disse utfordringene. Vi ønsker blant annet å fokusere på skillet mellom mål, i dette tilfellet bevaring av naturmangfoldet, og virkemidler, her snakk om kartleggings- og verdisettingsmetodikken. Særlig knyttet til virkemidlene vil vi ta for oss rollen til vitenskapelige data og skjønn i slike prosesser. Gjennom denne diskusjonen vil vi sette lys på det som ser ut til å være en konflikt mellom teori og praksis: På den ene siden kravet fra Stortinget (Klima- og miljøverndepartementet, op.cit.) til objektivitet og verdinøytralitet, og på den andre siden behovet for å beskrive usikkerhet og skjønn, samt balansegangen mellom detaljeringsgrad i kartleggingen og ulike brukerbehov.

\section{Naturtypekartlegging - historisk utvikling}

Naturtyper som et definert forvaltningsverktøy kom inn i norsk arealforvaltning gjennom kartleggingshåndboken til Direktoratet for naturforvaltning (1999). Stortinget bestemte i 1997 at «alle landets kommuner skulle gjennomføre kartlegging og verdisetting av viktige områder for biologisk mangfold på sine arealer», og målet var å få gjort dette innen 2003 (St.meld. nr. 58 (1996-1997)). Nå gikk det litt mer tid før alle kommunene fikk startet opp arbeidet, og full arealdekning er ennå ikke oppnådd. Samarbeidsrådet for biologisk mangfold (Sabima, 2017) har oppgitt at ca. $25 \%$ av verdifull natur er kartlagt så langt. Blindheim (2015) opererte med 30-70 \%. Like fullt har dette som forvaltningsverktøy fått stort gjennomslag. Det benyttes i omfattende grad som virkemiddel for å bevare naturverdier utenfor de nasjonale verneområdene, og det er utarbeidet veiledere til konsekvensutredninger som i praksis vektlegger disse naturtypene tungt. Dette arbeidet er utført av Statens vegvesen (2015) for vegprosjekt og NVE (Korbøl mfl., 2009) for småkraftutbygginger. Begrepet «naturtype» ble samtidig videreført i nye naturmangfoldloven fra 2009, og har fătt en sentral plass der, ${ }^{1}$ bl.a. gjennom en egen paragraf for beskyttelse av utvalgte naturtyper.

$1 \quad$ Naturmangfoldloven $\S_{3}$ - definisjoner, punkt j: «naturtype: ensartet type natur som omfatter alle levende organismer og de miljøfaktorene som virker der, eller spesielle typer naturforekomster som dammer, åkerholmer eller lignende, samt spesielle typer geologiske forekomster» 
Det ble likevel gradvis klarere at metoden hadde svakheter. Både naturtypeinndelingen og verdsettingssystemet (prioriteringssystemet mellom naturtypelokalitetene) var preget av skjønnsmessige, erfaringsbaserte vurderinger hos metodeutviklerne. Og ikke minst la metoden opp til betydelig utøvelse av skjønn hos den enkelte kartlegger, spesielt i verdisettingen av naturtypelokaliteter. Dette gjorde det vanskelig å etterprøve resultatene, mulighetene for å generere statistikk var begrenset og faren for bruk av personlige preferanser og subjektive valg hos kartleggerne var til stede. Ved utarbeidelse av en rødliste for vegetasjonstyper (Fremstad \& Moen, 2001) hadde svakhetene med etablerte inndelinger av naturmangfoldet i Norge blitt tydelige, og et bedre system ble etterlyst.

I 2005/2006 startet derfor prosessen med å lage et nytt inndelingssystem - Natur i Norge (NiN) - i regi av Artsdatabanken. En første versjon kom i 2009 (NiN1.o), og en ny, vesentlig bearbeidet versjon kom i 2015 (NiN2.o) (Bryn \& Halvorsen, 2015). Samtidig satte Direktoratet for naturforvaltning (som ble omorganisert og skiftet navn til Miljødirektoratet i 2015) i 2011 i gang en prosess med å revidere håndboka for kartlegging av verdifulle naturtyper. Formålet var både å integrere NiN-systemet $\mathrm{i}$ metodikken, å redusere deler av skjønnsbruken (særlig hos kartleggerne) og å forbedre verdisettingssystemet.

Metodeutviklingen tok en ny retning i 2014. Politiske prosesser medførte på den ene siden en del omorganisering av arbeidet i Miljødirektoratet. I tillegg kom et politisk vedtak om å satse på utvikling av økologiske grunnkart, noe som førte til en vesentlig økning i de statlige tilskuddene til kartlegging av naturtyper. I 2017 ble det satt av nesten 70 millioner kroner på statsbudsjettet til arbeidet med disse grunnkartene. Samtidig bestemte Miljødirektoratet i 2015 seg for å stanse den opprinnelige revisjonen av DN-håndbok 13 (Bjørkvoll \& Riisberg, 2016), og i stedet foreta en større endring i metodikken, bl.a. basert på en kartleggingsveileder for NiN, utarbeidet av Universitetet i Oslo (Bryn \& Halvorsen, 2015). Et nytt system for verdisetting ble lagt fram tidlig i 2017 (Evju mfl., 2017a). Dette ble utprøvd samme sesong, og en revisjon presentert på høsten (Evju mfl., 2017b). Miljødirektoratet har i denne prosessen etterstrebet å skille verdisettingen mest mulig fra registreringsdelen, der kartleggerne primært utfører sistnevnte del av prosessen. Fokuseringen på kartlegging av norsk 
natur har altså økt i denne perioden, samtidig som metodene har vært i mer eller mindre kontinuerlig endring i snart ti år.

\section{God måloppnåelse krever bruk av strategier og verdier}

En ryddig beslutningsprosess krever et klart skille mellom underliggende fakta og i neste omgang bruken av disse når en treffer valg basert på fastlagte mål, gjerne kalt en separering (Sundqvist mfl., 2015). Dette har hele tiden vært en ambisjon i naturtypekartleggingen, der et vitenskapelig basert registreringsgrunnlag (fakta) tilsynelatende har vært tydelig adskilt fra verdisettingen (der fakta selekteres ut fra fastlagte bevaringsmål). Når det kommer til stykket, er virkeligheten ikke likevel like klar og enkel.

Mål kan oppnås gjennom ulike framgangsmåter, men disse kan gi varierende grad av måloppnåelse og ressursbruk. I metodeutviklingen stilles vi derfor overfor valg, både når det gjelder hvilke fakta man skal innhente, og hvor mye man skal vektlegge ulike deler av disse faktaene. Derfor er det hensiktsmessig å utvikle strategier for å treffe gode valg, samt for å forstå sammenhengen mellom valgene og målet. I naturtypekartleggingen kan målet enkelt beskrives som å ta vare på biologisk mangfold. En god strategi for å oppnå dette kan være å skille arealer med høy artsrikdom og sjeldne arter fra «vanlig» natur gjennom kartlegging. Ressursmessig kan det være en god strategi å stille ulike kartleggingskrav - avhengig av naturtype. Målet oppnås i første rekke gjennom det utvalget av naturtyper som man ender opp med å kartlegge som viktige. For å gradere måloppnåelsen, i dette tilfellet hvor godt utvalget av naturtyper treffer målet om å ta vare på biologisk mangfold, er det nyttig å bruke et verdisettingssystem. I virkeligheten er det sjelden man kan oppnå målet fullt ut, blant annet fordi man gjerne står overfor ulike mål som er i konflikt med hverandre, noe som tvinger fram kompromiss. Konsekvensutredninger og høringsrunder i arealplansaker er derfor sentrale verktøy for å kunne veie ulike interessegrupper og mål opp mot hverandre på en ryddig måte. Et harmonisert verdisettingssystem vil da hjelpe oss med å sammenligne måloppnåelsen mellom ulike forvaltningsmål. Verdisetting er et metodisk virkemiddel for å gradere måloppnåelsen. 
Forholdet mellom strategier, verdier og mål kan lett bli uklare, der det er vanskelig å se hva som er hva. Dette er behandlet av Erikstad (2015), som argumenterer for at det som i naturtypekartleggingen blir kalt verdisetting, kanskje heller burde vært betegnet som strategier for bevaring av naturmangfold. Dette er fulgt opp av Miljødirektoratet i arbeidet med naturtyper av nasjonal forvaltningsinteresse, hvor det tydelig uttrykkes at naturverdien til lokaliteter vil være avhengig både av forvaltningens strategi for å ta vare på slike, og naturkvaliteter ved den enkelte lokalitet (Bjørkvoll \& Riisberg, 2016).

Erikstad (op.cit.) ser videre en utfordring i den nære koblingen mellom verdibegrepet og våre grunnleggende holdninger, altså verdisyn. ${ }^{2}$ Det kan være at denne egentlig svært ulike bruken av begrepet «verdi», dels som et system for å systematisere våre valg og dels for å beskrive grunnen (målet) til de valgene man har foretatt, er noe av grunnlaget for en skepsis til verdisetting blant flere. Og det kan i neste omgang skape forvirring $\mathrm{i}$ begrepsforståelsen for mange. Det blir med andre ord lett til at en blander mål og virkemidler, og at en kan ende opp med å debattere og kritisere virkemidlene når det egentlig er målene som utgjør konflikten.

\section{Et verdinøytralt naturtypesystem er ikke gjennomførbart}

Det er et ønske i naturtypekartleggingen at verdsettingsmetodikken, altså strategiene for å oppnå målet om å ta vare på biologisk mangfold, skal bygges på underliggende, verdinøytrale fakta. Dette er etterspurt av Stortinget, men hva som menes med verdinøytralitet, virker ikke like klart. Skal det gjelde både i metodeutviklingen og ved kartlegging? Naturen kan nok sies å være verdinøytral, den har ikke noe mål eller noen bevisst retning. Vår kunnskap om den og organiseringen av denne kunnskapen er derimot menneskeskapt, og denne er det vesentlig mer tvilsomt å betegne som nøytral.

2 Erikstad (2015): «Verdi kan kobles til en varig overbevisning om hva som er viktig og riktig (for oss) og representer grunnleggende og dypt forankrede standarder og oppfatninger.» 
Ved utvikling av NiN-systemet, som i naturtypekartleggingen representerer underliggende fakta for verdisettingsmetodikken, uttrykte blant annet Bryn (2015) et klart ønske om at dette skulle være mest mulig verdinøytralt. Det skulle gjelde både selve systemet og anvendelsen av det i praktisk kartlegging.

Om en med verdinøytralitet primært mener målet en sikter mot, dvs. at metodikken skal kunne benyttes til ulike formål, blir holdningen tilsynelatende fornuftig og delvis gjennomførbar. Desto flere bruksområder en metodikk kan ha, desto mer etterspurt kan den i teorien bli. Og det bør være mulig å utvikle en metode som kan anvendes i ulike sammenhenger. Faren er likevel at svakhetene blir større enn fordelene, og dette ser i liten grad ut til å ha blitt diskutert av myndighetene eller blant metodeutviklerne. For at kartleggingen skal kunne innhente de faktaene som trengs for å gjennomføre den videre verdisettingen, må naturtypesystemet og kartleggingsmetodikken være rettet mot det endelige målet. Dermed kan idealet om en verdinøytral kartlegging virke merkelig, også med tanke på sammenhengen mellom mål, verdier og strategier, som ble beskrevet i forrige kapittel. Det er sjeldent effektivt å forsøke å strekke seg etter flere mål samtidig. Ikke minst er det ressurskrevende, og det kan føre til mer utydelig målfokusering og dårligere måloppnåelse (modellfeil).

Om en med verdinøytralitet derimot sikter til verdisetting som virkemiddel for å gradere måloppnåelsen (se over), blir det vanskelig å forstå fornuften i en slik ambisjon. En metodikk vil sannsynligvis bli mest mulig ryddig, oversiktlig og ikke minst etterprøvbar hvis den inneholder systemer for verdisetting. Alternative løsninger må i større grad basere seg på skjønn og subjektive valg. Det er flere grunner til at det ved utvikling av avanserte sivilisasjoner blir en overgang fra byttehandel med reelle varer til transaksjoner med fast definerte valutaer. Mulighetene for å forenkle transaksjonene og kunne sammenligne og etterprøve byttene som foretas, gjør vel at de fleste ikke ser noen seriøs vei tilbake.

Det er viktig å være klar over at NiN-metodikken og anvendelsen av den heller ikke har klart å bli verdinøytral i betydningen av fravær av grunnleggende holdninger, altså verdisyn. For den praktiske kartleggingen ble dette klart uttrykt i den første kartleggingsveilederen (Bryn \& Halvorsen, 2015). Allerede på innsiden av omslaget presenterte de en rekke sitat for å 
underbygge utfordringene knyttet til kartleggingsvalg, ${ }^{3}$ og det virker opplagt at underliggende holdninger - og dermed verdisyn - vil spille en rolle hos de som tar valgene. Det er urimelig å forvente at valgene som tas, blir helt tilfeldige.

Samtidig var det også nødvendig å foreta en rekke valg ved utvikling av metodikken. Det skjedde flere viktige endringer i overgangen mellom NiN1.o og NiN2.o, der målet var å få et mest mulig stabilt system (Halvorsen mfl., 2015). Et av de mest sentrale grepene som ble tatt, var å etablere en vekting av de ulike organismegruppenes betydning for å definere hovedtyper og grunntyper i det reviderte systemet (se Halvorsen mfl., 2015, s. 55-57). Her foretok de et tydelig verdivalg med hensyn til hvilke arter som skulle vektlegges, og hvor stor vekt disse skulle bli tillagt, for å få en systematisk og etterprøvbar metode.

Utprøvingen av nytt verdisettingssystem for å ta vare på naturmangfoldet (Evju mfl., 2017a) har vist hvordan ulike, mer eller mindre bevisste valg medfører store forskjeller i utformingen av operativ metodikk. Ikke minst beskriver Thylén mfl. (2017) utfordringene i sin evaluering av forslaget til system, og er kritiske til løsningen. De viser til det store omfanget av valg i utforming av $\mathrm{NiN}$, både gjennom rammene for metoden, $\mathrm{i}$ dens valg av komponenter og parametere, og gjennom bruk av ulike verdiskalaer. Samt i neste omgang valg som foretas både av kartleggerne og av databrukerne. De kritiserer videre den skjematiske og detaljerte metodikken for i for liten grad å synliggjøre skjønnsmessige valg, og argumenterer for økt anvendelse av erfaringsbasert kunnskap og prosa.

Også de andre miljøene (Gaarder mfl., 2017; Johansen mfl., 2017; Myklebust mfl., 2017) som prøvde ut metodikken, hadde mange, sprikende og til dels vidtrekkende forslag til endringer. Det bød i neste omgang på

3 Halvorsen \& Bryn, 2015, innsiden av omslaget: «You map what you value, and you value what you map.' Om pandaer i kartleggingsarbeid, fritt omskrevet av undertegnede. '- I denne jobben er det sjelden svart-hvitt-beslutninger. - Vi veier for og imot og gjør det vi tror er mest riktig, men det er hele tiden under tvil'. Rentedirektør Trond Bentestuen i DNB, Aftenposten, søndag 4. mai 2014. '-Varje beskrivning av vegetationen har den bristen, att skarpa gränser mellan vegetationstyper nästan aldrig finns. - Avgränsningarna och benämningarna måste alltså bli godtyckliga. - Genom tradition, förmedlat i litteraturen och vid gemensamt inventeringsarbete, kan dock avgränsningar och benämningar bli mer allmängiltiga.' Naturinteressert kirurg, Anders Delin. Svensk Botanisk Tidsskrift 1992.» 
store utfordringer å analysere og evaluere alle disse innspillene uten å basere seg på mer eller mindre bevisste verdivalg. Evju mfl. (2017b) unngikk i sin oppsummering av metodeutprøvingen stort sett å referere til evalueringsrapportene. De fokuserte i stedet på å presentere sin oppfatning av problematikken (et fast punkt i deres rapport var «ekspertgruppa mener») og i neste omgang sitt forslag til løsning. En slik framgangsmåte fører sannsynligvis til at de subjektive og skjønnsmessige elementene i anvendelsen av ny verdisettingsmetodikk blir redusert. Derimot er det vanskelig å se at den sikrer at selve metodikken får et mer objektivt og nøytralt grunnlag. Faren er fortsatt til stede for resultater bygd på et like subjektivt og usikkert grunnlag som tidligere, men det har blitt lettere å framstille dem som objektive og sikre. Det bør være velkjent at det er fristende og effektivt å skjule svakheter i konklusjoner bak tall og statistikk.

Til tross for innvendingene som kan fremmes mot nøytralitetsbegrepet, påvisning av diskutable valg som tas, og usikkerhet i resultater, insisterer likevel Miljødirektoratet fortsatt på at metodikk og resultater er verdinøytrale og uten forbehold. Dette skjer senest i planene for naturtypekartlegging i perioden 2018-2020 (Miljødirektoratet, 2018). Behovet for å tilfredsstille Stortingets ønsker, og dermed skjule alle svakheter ved bestillingen derfra, virker tydelig. Dette øker i neste omgang presset på fagmiljøene som skal stå for den praktiske gjennomføringen, og faren for at også de får problemer med å presentere og diskutere metodikk og data på en åpen måte. Ikke minst ser det ut til at dilemmaene som oppstår i møte mellom forskning og politikk, blir lite fristende å ta opp.

\section{Bruken av skjønn og beskrivelse av usikkerhet}

Halvorsen mfl. (2015) hadde ved revisjonen av NiN som mål om å unngå at «subjektive oppfatninger, personlige preferanser, ubevisste eller bevisste verdivalg og skjulte agendaer» skulle påvirke utviklingen av metoden. Dette var en svært ambisiøs målsetting og indikerer et utpreget positivistisk vitenskapssyn, altså en tro på at det er mulig å foreta objektive, verdinøytrale og interessefrie valg. Særlig det å unngå ubevisste valg virker både naivt og urealistisk, selv om en i utgangspunktet er klar over utfordringen. I tillegg er vi uenige $i$ at en ikke skal benytte bevisste verdivalg 
som virkemiddel for å få et etterprøvbart system basert på en overordnet målsetting. Halvorsen mfl. (2015) unngikk da heller ikke slike valg, jf. forrige kapittel. Vi er også uenige i at en skal unngå bevisste verdivalg $\mathrm{i}$ betydningen å sette seg klare mål, da dette er nødvendig for å få en ryddig, relevant og forståelig metodikk. Å unngå subjektive oppfatninger, personlige preferanser og skjulte agendaer vil derimot være allmenngyldige prinsipper.

Bay-Larsen (2014) trekker fram at etablering av fakta i en kunnskapsbasert forvaltning krever en rekke prioriteringer og vurderinger, ikke bare vitenskapelige, men også økonomiske, administrative og skjønnsmessige. Dette gjelder også ved utvikling av ny metodikk for verdisetting av naturtyper. Eksempelvis understreket Miljødirektoratet i sin bestilling at de ønsket en kostnadseffektiv metodikk, og Evju mfl. (2017b) trekker fram variasjon og begrensninger i kartleggernes artskompetanse som et sentralt argument for å redusere vektleggingen av arter i metodikken.

I praksis er det i en slik prosess umulig å unngå subjektive oppfatninger og ubevisste verdivalg. Det kan bli mange trinn i prosessen mellom et overordnet mål og den operative metoden som utvikles for å nå dette, og faren er stor for at metoden gir resultater som i større eller mindre grad bommer på målet. De Jongh (1988) beskriver tre aktuelle typer strukturelle modellfeil:

- Prosessfeil: En modell skal forenkle virkeligheten, og faren er at den kan utelate vesentlige sammenhenger.

- Funksjonsfeil: Modellen klarer ikke å beskrive sammenhengene, dvs. forholdene mellom årsak og virkning.

- Beslutningsfeil: Modellen er ikke gyldig for den aktuelle problemstillingen.

Uansett om en kaller det feil eller bare unøyaktighet, vil ikke en metode bli perfekt. Den vil inneholde en viss grad av usikkerhet på alle de punktene De Jongh (1988) lister opp. Og for alle de tre typene modellfeil vil årsakene delvis kunne tilskrives subjektive eller ubevisste verdivalg, kanskje også skjulte agendaer. Dette er ikke minst utfordrende ved naturtypekartlegging. Halvorsen mfl. (2009) slo allerede ved oppstarten 
av NiN-metodens utvikling fast at naturen er dominert av gradvise overganger i artssammensetningen. Skarpe, tydelige grenser forekommer kun i liten grad. En viss grad av unøyaktighet er derfor ikke til å unngå, både ved utvikling av metoden og ved praktisk anvendelse av den. Ikke minst i dette perspektivet var det store utfordringer knyttet til kartleggingsvalgene som Halvorsen mfl. (2015) innledet sin veileder med.

I praktisk naturmangfoldkartlegging kunne mange av disse valgproblemene trolig vært unngått om en i stedet hadde basert systemet mer direkte på registrering av arter, og ikke forsøkt å utlede en naturtypeinndeling basert på ulike artssammensetninger. Arter representerer en objektiv og relativt stabil økologisk enhet, der gradvise overganger eller behov for etablering av subjektive inndelingssystemer er mindre aktuelle problemstillinger. Spørsmålet er om det store artsmangfoldet og det uendelige antallet kombinasjoner dette opptrer i, likevel kan bli for komplisert å forholde seg til - både for kartleggerne og i forvaltningen. Vi har alle klare begrensninger i kompetanse og kognitiv arbeidskapasitet, og det er også grenser for hvor komplisert en metode kan være uten at en mister oversikten. I stedet må en forenkle gjennom å fokusere på naturtyper, og dermed akseptere en fare for å havne i en eller flere av De Jonghs (op.cit.) modellfeil, ikke minst prosessfeil. Dessverre virker det som om både politikere, byråkrater og deler av det naturfaglige miljøet har vært lite villig til å evaluere disse utfordringene. Evju mfl. (2018) har i liten grad diskutert dette, og i det minste offentlig har Miljødirektoratet ikke gitt uttrykk for noen kritisk evaluering av den nye metodikken på dette punktet.

En annen måte å beskrive lite kvantifiserbare og usikre valg på i praktisk kartlegging er å anvende faglig skjønn. Best mulig faglig skjønn er framhevet av Tennøy (2014) som et av de viktigste grunnlagene for høy faglig kvalitet i konsekvensanalyser. Dette er i samsvar med et konstruktivistisk vitenskapssyn, der faglig skjønn og fortolkninger er en viktig del av kunnskapsproduksjonen. For naturtypekartlegging ble behovet for bruk av faglig skjønn behandlet av Løvdal mfl. (2002) i utviklingen av Siste Sjanse-metoden. De tok for seg avveiningene mellom bruk av skjønn og vitenskapelig kunnskap i sin metodikk, og vektla tydelig behovet for 
skjønnsutøvelse. ${ }^{4}$ Denne metoden var et viktig grunnlag for metodikken til Direktoratet for naturforvaltning (1999).

Løvdal mfl. (2002) kritiserte enkelte andre metoder for verdisetting av naturmangfold for å ha skjult skjønnsutøvelsen og de valgene som ble tatt i utviklingen av metodene. Denne kritikken ble rettet mot skogbrukets Miljøregistrering i Skog (MiS) og miljøforvaltningens system for verdisetting av vassdrag i Samlet plan. Her kan det ligge en interessant forskjell mellom NiN og Siste Sjanse-metoden på den ene siden og MiS og Samlet plan på den andre. Mens de to førstnevnte i hovedsak har vært utviklet i reine naturfaglige miljøer, ble de to sistnevnte i mye sterkere grad utviklet av det offentlige byråkratiet. Det er også stor uenighet innad i de naturfaglige miljøene om hvor mye og hvordan skjønnet synliggjøres. Dette ble synlig i evalueringen av den nye verdisettingsmetodikken. Blant annet viste Myklebust mfl. (2017) til ønsket om en mer objektiv kartlegging med resultater uavhengig av kartleggerne. Samtidig trakk de fram at «Våre mest erfarne kartleggere mener imidlertid at en ren objektiv kvantitativ analyse ikke er nok, og at kvantifiserbare parametere ikke kan fange opp alle verdiaspekter. Det må være rom for faglig skjønn, der man ser at spesielle verdiaspekter ikke fanges opp.» Evju mfl. (2017b) foreslår at anvendt metodikk skal basere seg på en viss grad av faglig skjønn i flere situasjoner, men diskuterer ikke temaet på et generelt eller prinsipielt grunnlag, bortsett fra at de mener sentrale variabler ikke bør baseres på skjønn. Samtidig har miljømyndighetene, eksempelvis Bjørkvoll og Riisberg (2016), de siste årene helt unnlatt å ta opp skjønn som tema.

Noe av forklaringen på dette spriket i synliggjøring av skjønnsutøvelse i anvendt metodikk kan også ligge i at beslutningstakere, enten de befinner seg i byråkratiet eller er politikere, stilles direkte til ansvar for de valgene de tar. Da er det ikke uventet at de ønsker mest mulig pålitelige og konkrete svar - som ikke er påvirket av hvem som har framskaffet dem. Og at de frykter usikkerhet og tvilsom skjønnsbruk. I metodeutviklingen kan dette i neste omgang gjøre dem mindre villig til å beskrive valgene

4 Løvdal mfl. (2002): «Med kvalifisert biologisk skjønn mener vi en faglig vurdering som baserer seg på fagbiologisk teori og erfaring, og som oftest lar seg begrunne, men som ikke uten videre lar seg kvantifisere.» 
de står overfor eller uttrykke usikkerhet ved disse valgene. En annen forklaring kan være at byråkrater og politikere i mindre grad er kjent med prinsippene for utvikling og anvendelse av vitenskapelige metoder, deriblant hva som anses som god praksis for synliggjøring av usikkerhet og skjønnsbruk.

Politisk motstand mot skjønnsbruk kan ytterligere presse metodeutviklerne til å beskrive metodene og valgene som tas, som vesentlig mer opplagte og sikre enn de i virkeligheten er. Når eksempelvis Stortinget krever en mest mulig verdinøytral naturtypekartlegging og samtidig sier at NiN skal legges til grunn, er det ikke lett å stå der som metodeutvikler og fortelle at metoden verken er helt objektiv eller nøytral. Selv om de klarer å framstille dette balansert, er det fortsatt en fare for at sekundærbrukere forsøker å skjule eller underdrive valgene og skjønnet som ligger bak.

Miljødirektoratet (dvs. det tidligere Direktoratet for naturforvaltning) ser som nevnt ut til å slite med åpenhet omkring skjønnsbruk og usikre valg som er tatt i naturtypekartleggingene. Nye kartlegginger og kontroller av arealer som ble kartlagt tidlig på 200o-tallet, utført av konsulenter på oppdrag fra miljøforvaltningen, avslørte svært varierende kvalitet på de gamle undersøkelsene. Miljøvernmyndighetene omtalte selv disse svakhetene i datasettene som var lagt ut på nettet, samtidig som de iverksatte nye kontroller. Både i den praktiske kartleggingen og i metodeutviklingen siden DN-håndbok 13 ble skrinlagt, virker derimot vektleggingen av kvalitet i beste fall uklar. Kartleggerne har hatt små muligheter til å beskrive ulike former for usikkerhet. Ved ferdigstillelse av datasett for heldekkende naturtypekartlegging høsten 2015 fikk kartleggerne beskjed om å fjerne (skjule) avvik som oppstod der to personer kartla inntil hverandre. I forkant av feltsesongen 2016 ble den forhåndsdefinerte usikkerheten knyttet til avgrensning (som var den eneste formen for usikkerhet som kunne legges inn i kartleggingsprogrammet på en standardisert måte) satt til maksimal sikkerhet (o-5 meter). Kartlegger måtte selv overstyre dette manuelt. Usikkerhet knyttet til naturtypevalg eller andre miljøvariabler kunne heller ikke uttrykkes på en ryddig måte, siden det nye systemet baserte seg fullt og helt på et databasesystem med avkrysning, uten muligheter for å angi usikkerhet i avkrysningsvalgene. Mangelen på muligheter for å uttrykke usikkerhet i kartleggingen gjør at 
kartleggingen foregår i en «svart boks», der etterprøvbarheten blir sterkt redusert. Det er underlig at Miljødirektoratet, som virker opptatt av at kartleggingsmetodikken skal være vitenskapelig basert, ikke tillater synliggjøring av usikkerhet. Usikkerhet rundt metode og feilkilder til resultatene bør være obligatorisk i enhver vitenskapelig artikkel, og mangel på muligheten til å synliggjøre usikkerhet strider dermed med etablert vitenskapelig praksis. Derimot kan høy usikkerhet i kartleggingen tolkes som et stort rom for skjønn, noe som kan komme i konflikt med oppgaven Miljødirektoratet har fått fra Stortinget.

Det er fortsatt fare for at kvaliteten på naturtypedata er svært varierende og har stor usikkerhet knyttet til seg, også der de er innhentet for å gjøre konkrete forvaltningsvalg. På oppdrag fra NVE ble det utført en kontroll av naturmangfolddata, som var kartlagt som del av utredningene for småkraftutbygginger (Gaarder \& Høitomt, 2015). Her ble det påvist svært store avvik i resultatene. Forklaringene virket sammensatte og omfattet både uklar skjønnsbruk, manglende ressurser og sviktende kompetanse. I etterkant er det likevel klart at tiltroen til å kunne utvikle et svært presist kartleggingsverktøy ble svekket som en følge av dette prosjektet, både hos kontrollørene og hos oppdragsgiver.

Faglige svakheter ved konsekvensutredninger er et kjent fenomen, og det er viktig å utvikle metoder og rutiner som forebygger dette. Tennøy (2014) diskuterer kvalitet på data på biologisk mangfold i konsekvensutredninger og trekker fram eksempler på utredninger der kontroller gir store avvik i resultatene, samt data og presentasjoner som er vinklet for å framstå mest mulig positive fra ståstedet til utreder/tiltakshaver. Hun setter samtidig opp fire kriterier for å sikre høy kvalitet på utredningene:

- usikkerhet $\mathrm{i}$ både forutsetninger, data og resultater må komme tydelig fram

- analyser må være transparente og etterprøvbare

- analyser og framstillinger må være hederlige

- analyser og framstillinger må være forståelige

Tennøy fokuserer på konsekvensutredninger, men de samme kriteriene bør være like sentrale ved anvendelsen av alle typer metoder. Selv om det 
kan føles ubehagelig både for utredere og oppdragsgivere at usikkerheten beskrives, må det likevel være en sentral del av oppdragsbesvarelsen. Bruk av skjønn vil ofte være en viktig forutsetning for å gjøre resultatene forståelige.

\section{Balansegangen mellom relevans og presisjon}

Skjønnet kan reduseres hvis metoden har et målbart og presist regelverk, noe som er positivt med tanke på Tennøys (2014) målsetting om etterprøvbarhet. Flytting eller fjerning av skjønnsbruk i naturtypekartleggingen har vært diskutert av bl.a. Løvdal mfl. (2002). Gaarder (2015) beskrev dette som en utfordring ved revisjon av Miljødirektoratet sin gamle naturtypemetodikk (DN-håndbok 13), og det er slett ikke uproblematisk.

En risiko ved å forsøke å fjerne skjønn er at det kan medføre økt ressursbehov ved innhenting og bearbeiding av data. Faren for økte kostnader har vært trukket fram i lengre tid, og senest Thylén og Blindheim (2017) advarer mot dette og frykter at kostnadene kan stige betydelig for naturtypekartleggingene. Ved utvikling av forvaltningsrettede metoder kan dette bli en viktig forstyrrende faktor med tanke på kvalitetskravene. Det vil være svært fristende for bevilgende myndigheter å foretrekke en metode med lavere grad av presisjon og økt skjønnsbruk, hvis det reduserer ressursbruken vesentlig.

Det er også et spørsmål om redusert skjønnsbruk kan påvirke måloppnåelsen. Dette har blitt debattert de siste par årene ved overgangen til bruk av NiN som grunnlag for naturtypekartleggingen (Gaarder, 2015b; Wegener, 2015). Kort formulert er målet å bevare naturmangfoldet. Definisjonen av naturmangfold er imidlertid svært vidtfavnende, ${ }^{5}$ noe som skaper store utfordringer ved operasjonalisering via en kartleggingsmetodikk, hvis en samtidig ønsker å redusere skjønnsbruken. Selv det å

5 Naturmangfoldloven $\$ 3$, punkt i: «naturmangfold: biologisk mangfold, landskapsmessig mangfold og geologisk mangfold, som ikke i det alt vesentlige er et resultat av menneskers påvirkning», og samme paragraf, punkt c: «biologisk mangfold: mangfoldet av økosystemer, arter og genetiske variasjoner innenfor artene, og de økologiske sammenhengene mellom disse komponentene». 
utlede delmål kan være vanskelig nok. Eksempelvis mente Pedersen mfl. (2017) at Miljødirektoratet hadde for vagt utformede målsettinger i arbeidet med å bevare naturmangfoldet i skog.

Ikke bare er tolkningen av målet krevende. I metodeutviklingen er det samtidig nødvendig å ta en rekke valg før en får et regelverk som er presist, operativt og etterprøvbart. Ethvert valg innebærer at alternative løsninger velges vekk, og faren for modellfeil oppstår, jf. De Jongh (1988). Valg må likevel tas, og jo mer vidtfavnende målet er, desto større kan kuttene bli. Dette kan så lede inn i en annen av De Jonghs feilkilder: at metoden ikke egentlig er relevant/gyldig med tanke på hva som skal besvares.

Derfor er det nødvendig å være varsom når en forsøker å redusere skjønnsbruken og øke graden av etterprøvbarhet, og ikke minst se kritisk på balansegangen mellom presisjon (nøyaktighet) og relevans (måloppnåelse). I utgangspunktet bør en ved utformingen av metodikk og bruken av den gå ut fra at alle valg som tas, reduserer graden av måloppnåelse. Utfordringen ligger dels i å være svært målbevisst når valgene tas, slik at en ikke beveger seg vekk fra målet, og dels i å beholde et tilstrekkelig bredt utvalg av løsninger (beholde ulike veier mot målet), slik at resultatene i det minste gir et dekkende/representativt bilde av målet, og at en unngår for store modellfeil.

Pedersen mfl. (2017) evaluerte et forsøk på å benytte NiN ved utvikling av ny skogvernmetodikk, og advarte da mot slike farer. De kom med flere råd angående behovet for et godt målfokus: «De praktiske metodene for registrering, kvantifisering og kartlegging av verneverdirelevante indikatorer må i første omgang utvikles og evalueres i lys av formålet med undersøkelsene og ikke ut fra hensyn til andre kartleggingsformål.» Samtidig var de skeptiske til en høy grad av presisjon: «For å oppnå repeterbar verdifastsetting bør robusthet i metodene vektlegges framfor fokus på økt presisjon i de innsamlede data.»

Etter vårt syn kan dette dilemmaet oppsummeres slik: Jo mer presis en metode er, desto større er risikoen for at den blir lite relevant for målet. Dette er illustrert i Figur 1.

Hvordan en skal opprettholde uavhengigheten til fagmiljøene og samtidig sikre en relevant metode, der kvaliteten på resultatene er sterkt 

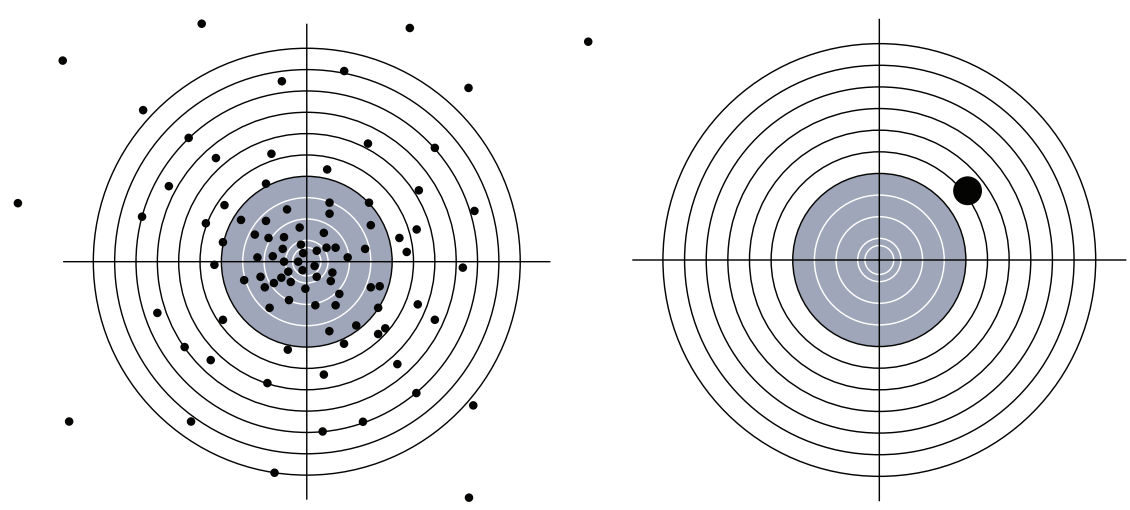

Figur 1. Hva er best, å ha en ganske grov, upresis metode, men der en tross alt er rimelig sikker på å treffe store deler av målet? Eller å ha en detaljert, svært presis metode, som bare treffer en liten del av målet, og kanskje til og med skjevt? Figuren er hentet fra Gaarder (2015a).

knyttet til relevansen, har tydeligvis ikke vært enkel. Det er utarbeidet et stort antall dokumenter som beskriver, forklarer og underbygger NiN-metodikken, der selv de overordnede, grunnleggende dokumentene gjerne er på flere hundre sider, tettpakket med faglig informasjon. Metodeutviklerne har i neste omgang gitt klar beskjed til bl.a. offentlige myndigheter om at NiN er ei verktøykasse der det blir opp til brukerne å plukke de delene de ser behov for. Likevel har de kommet med råd og veiledning om hvordan systemet i praksis skal brukes, inkludert den detaljerte kartleggingsveilederen (Bryn \& Halvorsen, 2015).

Den umiddelbare konsekvensen av disse utfordringene bør være at brukerne må ha en klar forståelse av egne behov og mål, samtidig som de må ha god oversikt over NiN-systemet og hva de ulike delene kan benyttes til. Dette er imidlertid svært kompetansekrevende. Brukerne må derfor utvikle en solid bestillerkompetanse, fordi fallgruvene er mange og lette å falle i. På den ene siden har de alltid ressursbegrensninger og må derfor unngå å bruke deler av NiN-systemet som er uforholdsmessig kostnadskrevende. På den andre siden skal de faktisk forsøke å oppfylle et svært bredt oppsatt mål og må passe på at kartleggingene gir tilstrekkelig informasjon til å fange opp målet på en tilfredsstillende måte. Hvordan skal de klare å foreta best mulig avveininger her?

Noen av disse utfordringene ser vi tydelig gjennom Miljødirektoratets videreutvikling av metoden for naturtypekartlegging fra den 
startet på 1990-tallet og fram til i dag. Opprinnelig fantes det svært generelle, grove regler for kartlegging og verdisetting av naturtyper. På den ene siden gav dette kartleggerne stor frihet og fleksibilitet, noe som potensielt sett kunne benyttes til å gjennomføre effektive kartlegginger godt tilpasset den store naturvariasjonen i Norge. På den andre siden førte det til stor variasjon i hvordan kartleggingene ble utført, og det var vanskelig for utenforstående å etterprøve resultatene.

En sentral målsetting ved revisjonen av DN-håndbok 13, som ble startet opp i 2011 og stanset i 2015, var å redusere denne anledningen til å utøve individuelt skjønn, og dermed forbedre mulighetene for sammenligninger og etterprøving. Dette skulle oppnås nettopp ved å etablere et klarere regelverk. Konsekvensene ble i neste omgang mer komplekse regler og ressurskrevende kartlegginger. En stor utfordring ble å passe på at en fortsatt klarte å fange opp mest mulig av ønsket variasjonsbredde i naturmangfoldet, dvs. beholde relevansen med tanke på det overordnede målet, til tross for økt presisjon i kartleggingen. Til å begynne med antok man at det ikke var mulig å unngå verdivalg og skjønnsutøvelse i metoden, men det var en målsetting å tydeliggjøre hvor i prosessen disse ble tatt (Angell-Petersen, 2015; Gaarder, 2015a). Det ble også forsøkt uttrykt klart at skjønnsutøvelsene ikke forsvant, men i første rekke flyttet, fra den enkelte kartlegger og over til de fagansvarlige for utarbeidelse av faktaark for hver naturtype (med tilhørende naturtypedefinisjoner og regelverk for verdisetting) (Angell-Petersen, 2015; Gaarder, 2013).

Faren var likevel hele tiden at skjønnsbruken i større grad kunne bli skjult. Det kunne skje ved at valgene bare ble tatt på et mer overordnet og mindre synlig nivå, samt av personer med større grad av faglig autoritet, men ikke nødvendigvis mindre preget av personlige preferanser. Dermed var det langt fra sikkert at kvaliteten på kartleggingene reelt sett ble bedre. De kunne like gjerne bli dårligere, målt etter Tennøys (2014) krav til beskrivelse av usikkerhet, hederlighet og forståelighet. Evalueringer av de nyeste forsøkene på verdisetting av naturtyper fra Miljødirektoratets side har da også faktisk medført en økende kritikk og skepsis til kvaliteten (se bl.a. Gaarder et al., 2017). 


\section{Behov for økt åpenhet og beskrivelse av usikkerhet}

Selv om en metode virker solid og god på enkelte punkt, vil den alltid ha svakheter på andre felt, og balansegangen mellom ulike hensyn og formål vil alltid være vanskelig. Da kan en falle for fristelsen til å overdrive de sterke sidene og være tilbakeholdne med de svake. Faren blir med andre ord at en forsøker å skjule:

- diskutable valg

- upresise sider

- kostnadsøkninger

- skjønnsbruk

Når en ser på den offentlige presentasjonen av resultater fra naturtypekartleggingene de siste par årene og myndighetenes omtale av systemet, er det vanskelig å finne spor etter bekymring for disse utfordringene. Resultatene framstilles som vellykkede, og kritiske diskusjoner i regi av myndighetene omkring måloppnåelse eller ressursbruk er sparsomme og fragmentariske. De naturvitenskapelige miljøene som har vært involvert i utviklingen av systemet, har i hovedsak vært tause utad.

For å redusere risikoen for at svakheter i metodikk og bruken av den blir skjult, tror vi en viktig del av løsningen ligger i vitenskapens krav til åpenhet. Og dette kan ikke minst synliggjøres gjennom å fokusere på usikkerhet i alle ledd i prosessen. Her viser vi til Strand og Orton (2009), som identifiserer seks ulike former for usikkerhet:

- usikkerhet i vitenskapelig/faglig kunnskapsgrunnlag

- usikkerhet i variasjon

- usikkerhet i data / numerisk usikkerhet

- usikkerhet i modellering

- usikkerhet knyttet til å spå om framtiden

- konseptuell usikkerhet

Det kan diskuteres om alle disse er like relevante for utviklingen av en naturtypemetodikk, men vi vil ikke gå mer detaljert inn på dem her. 
Poenget er å framheve nytten og viktigheten av å vinkle mot den usikkerheten som vil oppstå når en lager en ny metodikk og senere anvender den. Det er så lett å se seg blind på de positive sidene og la seg overbevise av tilsynelatende presise konklusjoner. Fokusering på usikkerhet kan derimot gjøre oss mer forsiktige - og forhåpentligvis ydmyke - når vi forsøker å lage en ny metode, og vi kan bli mer oppmerksomme på fallgruver, svakheter og målfeil. Kanskje kan vi også bli mer nyanserte og åpne for alternative løsninger?

I anvendelsen av metoden er fokusering på usikkerhet selvsagt sentralt - både for å unngå misbruk av resultatene og for å kunne gi konstruktive advarsler om at virkeligheten kanskje kan være en annen. I tillegg kan det forhåpentligvis også føre til at de som utfører utredningene, anstrenger seg mer nettopp for å redusere usikkerheten.

\section{Avsluttende merknader}

Utvikling av ny metodikk for naturtypekartlegging har blitt en komplisert og langvarig prosess, der det har vist seg vanskelig å utvikle et velegnet, solid og målrettet verktøy. I praksis har en her havnet i fallgruva som Sundqvist mfl. (2015) har advart mot, der ledende miljøer i utformingen av den kunnskapsbaserte forvaltningen har reflektert lite over dynamikken mellom de to dimensjonene separasjon (mellom naturvitenskap og forvaltning) og formalisering (av metodikk). En har stått ovenfor mange vanskelige avveininger, der det spenningsfeltet som oppstår når en skal tilpasse naturvitenskapelig kunnskap til forvaltningsmål satt fram av politikere, kanskje er den største utfordringen. Dessverre har temaet hittil kun i liten grad blitt kritisk diskutert innenfor en bred fagteoretisk ramme, der forskjeller i verdisyn og utfordringer knyttet til modellfeil og usikkerhet burde vært noen av grunnlagene for debatten. I stedet fremmer miljøvernmyndighetene en oppfatning om at det kan etableres et skarpt skille mellom den naturfaglige kunnskapsproduksjonen og bruken av den i forvaltningen, og at ny metodikk gir resultater med høy presisjon og høy grad av måloppnåelse. Dette fører lett til en polarisert debatt som stanser konstruktiv videreutvikling. Vi mener i stedet at disse utfordringene krever en bevissthet og ydmykhet hos alle medvirkende 
aktører, enten de befinner seg i forskningsmiljøer eller i forvaltningen, for at vi skal komme fram til et godt sluttprodukt. Og det er behov for en kontinuerlig debatt omkring både metodikk og anvendelsen av den. Det vil hele tiden være et press mot raske, enkle og billige løsninger, samtidig som forventninger og mål kan være vage og ufullstendig formulert. Erfaringene med revisjon av naturtypemetodikken tilsier etter vårt syn at $\mathrm{i}$ hvert fall følgende rettesnorer er nødvendige:

- kompetanse: En setter seg på forhånd godt inn i premisser, begrepsbruk, ulike relevante fagfelt og bruksformål, slik at en har oversikt over valgene som må tas, og er bevisst på både dilemmaene og konsekvensene.

- åpenhet: Valgene og konsekvensene av dem framstilles åpent, inkludert beskrivelse av usikkerhet knyttet til dem - og helst også alternative løsninger. Både reint naturfaglige problemstillinger og virkninger av ressursbruk må behandles.

- tålmodighet: En har tålmodighet til å prøve ut og reflektere over ulike løsninger og godta at det faktisk krever mye tid og mange ressurser for å utvikle en god metode.

For kartlegging av naturtyper som er viktige for bevaring av naturmangfoldet, kreves det klare, operative målformuleringer, utstrakt bruk av verdisetting, bevisst skjønnsbruk og oppmerksomhet rundt usikkerhet i hele prosessen. Verdinøytraliteten som Stortinget har etterspurt, bør derimot ha lav prioritet $i$ en slik prosess. Hvis ikke er faren tvert imot at resultatet faktisk blir i samsvar med hva ønsket tilsynelatende kan bety: Kartleggingen blir uten verdi - altså verdiløs.

\section{Referanser}

Angell-Petersen, I. (2015). Revisjon av DN-håndbok 13 - oppsummering av arbeidet 2011-2015. Miljødirektoratet. Notat, 21 s.

Baumann, C., Gjerde, I., Blom, H.H., Sætersdal, M., Nilsen, J.-E., Løken, B., \& Ekanger, I. (Red.) (2001). Miljøregistrering i skog - biologisk mangfold. Håndbok i registrering av livsmiljøer i skog, Totalt 4 hefter. Skogforsk, NIJOS, Landbruksdepartementet. 
Bay-Larsen, I. 2014. Kunnskap i norsk miljøplanlegging - relevans, troverdighet og legitimitet. Kart og plan 74: 266-279.

Blindheim, T. (2015). Kartlegging av naturtyper i Norge 1999-2014. http://www. biofokus.no/kartlegging-av-naturtyper-i-norge-1999-2014/\#

Bjørkvoll, E., \& Riisberg, I. (2016). Naturtyper av nasjonal forvaltningsinteresse og verdisetting av kartlagte lokaliteter - Beskrivelse av konsept. Miljødirektoratet. Notat, 9 s.

Bryn, A. (2015). NiN-kartlegging. Terrestrisk natursystem-nivå. NiN-seminar 27. mai 2015. PPT-presentasjon, $112 \mathrm{~s}$.

Bryn, A., \& Halvorsen, R. (2015). Veileder for kartlegging av terrestrisk naturvariasjon etter $\mathrm{NiN}$ 2.o. Veileder versjon 2.0.oa. Naturhistorisk museum, Universitetet i Oslo. $228 \mathrm{~s}$.

De Jongh, P. (1988). Uncertainty in EIA. I P. Warthern (Red.), Environmental impact assessment - Theory and practice. Routledge: London.

Erikstad, L. (2015). Verdikriterier knyttet til utvalg av naturtyper i Håndbok 13 om kartlegging og verdisetting av naturtyper. Notat - NINA Minirapport 543, 19 s.

Evju, M., Blom, H., Brandrud, T.E., Bär, A., Johansen, L., Lyngstad, A., Øien, D.-I., \& Aarrestad, P.A. (2017a). Verdisetting av naturtyper av nasjonal forvaltningsinteresse. Forslag til metodikk - NINA Rapport 1357, $172 \mathrm{s.}$

Evju, M., Blom, H., Brandrud, T.E., Bär, A., Lyngstad, A., Øien, D.-I., \& Aarrestad, P.A. (2017b). Naturtyper av nasjonal forvaltningsinteresse. Revidert forslag til vurdering av lokalitetskvalitet. NINA Rapport 1428, $95 \mathrm{~s}$.

Framstad, E. (2015). Kunnskapsbasert naturforvaltning - kommentarer til Representantforslag 89S. NINA. Notat, $6 \mathrm{s.}$

Fremstad, E., \& Moen, A. (Red.) (2001). Truete vegetasjonstyper i Norge. NTNU Vitenskapsmuseet Rapp. bot. Ser. 2001-4: 1-231.

Gjerde, I., \& Baumann, C. (Red.) (2002). Miljøregistrering i skog - biologisk mangfold. Hovedrapport. Skogforsk. Norsk institutt for skogforskning, Ås. $224 \mathrm{~s}$.

Gaarder, G. (2013). Retningslinjer for verdisetting i faktaark for verdifulle naturtyper. Notat, $7 \mathrm{~s}$.

Gaarder, G. (2015a). Kartlegging og verdsetting av naturtyper. Kunnskaps- og erfaringsgrunnlag for revisjon av DN-Håndbok 13-1999. Miljøfaglig Utredning, rapport 2015: 24, $55 \mathrm{~s}$.

Gaarder, G. (2015b). Erfaring med heldekkende naturtypekartlegging etter NiN 2.0 - med basis i myrkartlegging i Nordland i 2015. PPT-presentasjon, $25 \mathrm{~s}$.

Gaarder, G., Hanssen, U., Ihlen, P.G., Jordal, J.B., Steinsvåg, K.M.F., \& Wangen, K. (2017). Verdisetting av naturtyper av nasjonal forvaltningsinteresse. Uttesting av metodikk. Miljøfaglig Utredning, rapport 2017-22, 106 s. + vedlegg.

Halvorsen, R., Andersen, T., Blom, H.H., Elvebakk, A., Elven, R., Erikstad, L., Gaarder, G., Moen, A., Mortensen, P.B., Norderhaug, A., Nygaard, K., Thorsnes, 
T., \& Ødegaard, F. (2009). Naturtyper i Norge - Teoretisk grunnlag, prinsipper for inndeling og definisjoner. Naturtyper $i$ Norge versjon 1.o. Artikkel 1: 1-210.

Halvorsen, R., Bryn, A., \& Erikstad, L. (2015). NiNs systemkjerne - teori, prinsipper og inndelingskriterier. Natur $i$ Norge, Artikkel 1 (versjon 2.0.2): 1-328 (Artsdatabanken, Trondheim; http://www.artsdatabanken.no.) https://www. artsdatabanken.no/Files/14541/NiNs_systemkjerne_teori,_prinsipper_og inndelingskriterier_(versjon_2.1.0)

Johansen, L., Bär, A., Wehn, S., Aune, S., Blanck, C., Blom, H.H., Daugstad, K., Engan, G., Grenne, S.N., Nordbakken, J.-F., \& Thorvaldsen, P. (2017). Uttesting av metodikk for kartlegging og verdisetting av naturtyper av nasjonal forvaltningsinteresse. NIBIO Rapport 3-120, $52 \mathrm{~s}$.

Klima- og miljødepartement (2016). Oppfølging av Meld. St. 14 (2015-2016) Natur for livet - Oppdrag til Miljødirektoratet om å styrke arbeidet med det økologiske grunnkartet. Brev av 01.12.2016 til Miljødirektoratet, $5 \mathrm{~s}$.

Korbøl, A., Kjellevold, D., \& Selboe, O.-K. (2009). Kartlegging og dokumentasjon av biologisk mangfold ved bygging av småkraftverk (1-10 MW) - revidert utgave. Veileder nr. 3/2009. NVE.

Lundteigen, P.O., \& Arnstad, M. (2014). Representantforslag 89 S. Dokument 8: 89 S (2013-2014), $4 \mathrm{~s}$.

Løvdal, I., Heggland, A., Gaarder, G., Røsok, Ø., Hjermann, D., \& Blindheim, T. (2002). Siste Sjanse-metoden: En systematisk gjennomgang av prinsipper og faglig begrunnelse. Siste Sjanse - rapport 2002-11, 151 s. + vedlegg.

Miljødirektoratet 2018. Miljødirektoratets plan for naturtypekartlegging for 20182020. Notat - utkast, 10 s. Av 11.06.2018.

Miljøverndepartementet (1984). Samla plan for vassdrag. Hovedrapport.

Myklebost, H.E., Jokerud, M., Bendiksen, E., Blaalid, R., Brandrud, T.E., Eilertsen, L., Töpper, J., Øien, D.-I., \& Aarrestad, P.A. 2017. Evaluering av kartleggings- og verdisettingsmetodikk for na-turtyper av nasjonal forvaltningsinteresse - NNF. Resultater fra verdikartlegging i 2017. NINA Rapport 1421. $111 \mathrm{~s}$.

Pedersen, B., Myklebost, H.E., Stabbetorp, O. og Framstad, E. (2017). Evaluering av forslag til metode for naturfaglige registreringer i skogvernarbeidet basert på Natur i Norge-systemet. NINA Rapport 1319. 77 s.

SABIMA (2017). Kartlegging av natur. https://www.sabima.no/kartlegging/ kartlegging-av-natur/

Statens vegvesen (2015). Konsekvensanalyser. Veiledning. Håndbok V712. $224 \mathrm{~s}$.

St.meld. nr. 58 (1996-97). Miljøpolitikk for en bærekraftig utvikling. Dugnad for framtida.

Strand, R., \& Orton, D. (2009). Risk and uncertainty as a research ethics challenge. The National Committee for Research Ethics in Science and Technology (NENT), Publication No. 9 2009, 42 s. 
Sundqvist, G., Bohlin, I., Hermansen, E.A.T., \& Yearley, S. (2015). Formalization and separation: A systematic basis for interpreting approaches to summarizing science for climate policy. Social Studies of Science, 45(3), 416-440.

Tennøy, A. (2014). Kvalitet i konsekvensanalyser. I F. Holth \& N.K. Winge (Red.), Konsekvensutredninger. Rettsregler, praksis og samfunnsvirkninger (s. 185-207). Oslo: Universitetsforlaget.

Thylén, A., \& Blindheim, T. (2017). Metodeutvikling for naturfaglige registreringer i skog. BioFokus-rapport 2017-4, 50 s. + vedlegg.

Thylén, A., Høitomt, T., Jansson, U., Kornstad, T., \& Blindheim, T. (2017). Evaluering av metodikk for kartlegging og verdisetting av naturtyper av nasjonal forvaltningsinteresse. BioFokus-rapport 2017-14. ISBN 978-82-8209-610-2. Oslo: Stiftelsen BioFokus.

Wegener, C. (2015). NiN-kartlegging anno 2015. Sett fra en kartleggers synsvinkel. PPT-presentasjon, $10 \mathrm{~s}$. 


\title{
«...så korrupte at jeg har ikke ord!» - Hets og sjikane i forskning
}

\author{
Norunn S. Myklebust \\ Administrerende direktør i Norsk institutt for naturforskning
}

\begin{abstract}
Critical feedback is an important driving force in research. Conducted in the appropriate arenas, within established ethical principles, it leads to progress. Social media provides a new, important channel for communicating research findings. However, social media has also become an arena for uncontrolled campaigns of criticism, lies and harassment against both individual researchers and research groups. While debate and critique are positive, systematic harassment and accusations of cheating and corruption are completely unacceptable. Applied research, by its nature, addresses issues of importance to society. Results are often used directly in political decisions and management decisions, creating potential for conflicts of interest. Two examples from NINA's research are the cause of losses in tame reindeer production and the effects of aquaculture on wild salmonids. In both cases, research results have had a decisive influence upon important industry and societal interests, leading to conflict. In this chapter I use my experience as director of NINA over the past ten years to reflect upon conflicts of interest in research. This experience has taught me that robust researchers with quality and integrity in their work are, with good support, able to face the storm when controversial research is publicised. Open debate in connection with research findings is vital for progress, and commitment demonstrates the relevance of research. An informed debate requires a sound information basis, which in turn will release further research funding. In the long term, research consequently benefits from debate, if the researcher can weather the storm.
\end{abstract}

Keywords: social media, harassment, conflict of interest, controversial research

\section{Innledning}

Sitatet i overskriften er hentet fra Facebook, og beskyldningen er direkte rettet mot forskere i Norsk institutt for naturforskning (NINA). Det kan

Sitering av dette kapitlet: Myklebust, N.S. (2019). «... så korrupte at jeg har ikke ord!» - Hets og sjikane i forskning. I H. Ingierd, I. Bay-Larsen \& K. Hiis Hauge (Red.), Interessekonflikter i forskning (s. 215-230). Oslo: Cappelen Damm Akademisk. https://doi.org/10.23865/noasp.63.ch10

Lisens: CC BY 4.0 
være krevende selv for erfarne forskere å stå i stormen når det hagler med usaklige påstander om juks og korrupsjon. Spesielt krevende er det når kritikken pågår over lang tid, og hvor dette fra forskernes ståsted oppleves som kampanjer for å devaluere forskningsresultater og svekke forskernes integritet og innflytelse. Dette er hverdagen for flere av NINAs forskere, men intensiteten og omfanget varierer selvfølgelig fra sak til sak.

Med utgangspunkt i eksempler fra forskning på tamrein og villaks vil jeg her utdype hvordan dette oppleves for forskerne og deres arbeidsgiver. I tillegg reflekterer jeg over noen forskningsetiske problemstillinger samt hvilke implikasjoner hets og sjikane kan ha for kunnskapsutvikling og demokrati.

\section{Kritikk av forskning}

Kritikk av ideer, hypoteser og forskningsresultater er en viktig drivkraft i forskningen. Publisering i vitenskapelige journaler er hovedarenaen både for forskning og for kritikk av den. Allerede under utdanning blir forskerne kjent med denne arenaen. Her råder anerkjente forskningsetiske prinsipper og respekt for faglig uenighet, og kampene utkjempes med kjente spilleregler. Dette gjelder for både grunnforskning og anvendt forskning.

Å levere forskningsresultater som bidrar til bedre miljøløsninger for samfunnet, er en viktig drivkraft i anvendt forskning. Samtidig ser vi at resultatene og forskerne bak dem noen ganger blir en del av interessekonflikter som er svært krevende å stå i over tid. Det er i en slik kontekst denne artikkelen er skrevet. Å manøvrere i dette landskapet krever mye av forskeren, og også av forskerkolleger og arbeidsgiver.

Politisk sett er flere av NINAs fagfelt svært aktuelle, og forskningsresultatene benyttes ofte direkte i beslutninger om forvaltning og politikk. Samtidig har vi erfart at ulike aktører søker å påvirke politikerne ved å stille kritiske spørsmål til NINAs forskning. Dette er helt legitimt, og forskerne må alltid kunne gjøre rede for usikkerhet i eget datamateriale samt styrker og svakheter med metodene som er benyttet. Samtidig er jeg opptatt av at politikere og journalister tar seg tid til å sjekke om det er hold i kritikken som fremmes, ved at de også stiller kritiske spørsmål til dem som ønsker å så tvil om forskningen og resultatene av den. Vi må 
være bevisst på hva som er vitenskapelig publiserte forskningsresultater, og hva som er upublisert kunnskap eller veltalende synsing. Upublisert kunnskap og erfaringsbasert kunnskap er viktig, men den må også vurderes opp mot vitenskapelig publiserte resultater.

Å fatte beslutninger i strid med råd basert på solid vitenskapelig kunnskap kan være akseptabelt så lenge kunnskapen anerkjennes, men beslutningstakere må da være klare på at det er andre forhold som vektlegges når beslutning fattes. Det er farlig dersom solid forskning og forskningsresultater blir underkjent og stemplet som dårlig arbeid som følge av kampanjer fra parter med egne faglige eller økonomiske interesser. Beslutningstakere risikerer å fatte beslutninger på feil grunnlag dersom de ikke ser den faglige verdien av vitenskapelig publiserte resultater.

\section{Erfaringer fra NINA}

Jeg har vært administrerende direktør i NINA siden 2007. Det har gitt meg mer enn ti års erfaring fra interessekonflikter i forskningen, og kompetanse på hvordan vi best kan støtte og veilede forskere som må stå i stormen. De siste årene er sosiale medier blitt en viktig kanal for formidling og diskusjon av forskningsresultater. Dessverre opplever vi at sosiale medier også er blitt arenaer for usaklig kritikk, løgn, sjikane og hets - både mot enkeltforskere og mot forskergrupper. Der finnes det ingen redaktører eller kjøreregler som styrer diskusjonene.

Erfaringene jeg har gjort meg, er at kvalitet og integritet i forskningen, god rolleforståelse, åpenhet og et godt apparat for kommunikasjonsrådgiving og beredskap er avgjørende for å være forberedt når potensielt kontroversielle forskningsresultater skal formidles.

Det spørsmålet jeg likevel ofte stiller meg, er hva usaklig kritikk og sjikane over tid gjør med forskerne? Hva må forskeren like - og tåle?

Jeg vil presentere to eksempler fra NINAs forskning. Dette er ikke en fullstendig analyse av konfliktene og årsaksforholdene, men jeg vil forsøke å belyse hvordan det er å levere anvendt forskning i konfliktfylte landskap. Det ene eksempelet er forskning på tapsårsaker i tamreindriften. Det andre er forskning på hvilke effekter havbruk har på vill laksefisk. I begge eksemplene er forskningsresultatene av stor og delvis avgjørende 
betydning for viktige nærings- og samfunnsinteresser. Naturlig nok har det vært store interessekonflikter med påfølgende strid om kunnskapsgrunnlaget rundt disse sakene.

\section{Tapsårsaker i reindriften}

Norsk tamreindrift foregår hovedsakelig i Nord-Norge, Trøndelag, Møre og Romsdal og Hedmark. Antallet rein varierer fra år til år, og i 2016 ble det anslått at det var om lag 212000 tamrein i Norge, mer enn 145000 av dem i Finnmark (Landbruksdirektoratet, 2016). En økning i rovviltbestandene i reinbeiteområdene regnes av næringen som en av de viktigste faktorene for lav kalvetilgang, store tap av dyr og dermed lav produksjon i tamreinflokkene i Norge.

NINAs faggruppe på tamreinrelaterte problemstillinger består av om lag femten forskere. I mer enn tretti år har gruppen drevet forskning på hvordan reintetthet, beiteressurser, klimatiske forhold og rovviltforekomster påvirker kalveproduksjon og overlevelse hos tamrein. Dette er viktig forskning som gir kunnskap til både forvaltningen av reindriften og forvaltning av rovviltbestandene.

I 2013 utga NINA en fagrapport som analyserte ulike datasett innsamlet over en periode på mer enn ti år, og som støttet seg til en rekke tidligere fagfellevurderte publikasjoner. Her konkluderte forskerne med at for mange rein på beitene, dårlig kondisjon på dyrene og ugunstige værforhold var de viktigste tapsårsakene i reindriftsnæringen. Kun en mindre del av de rapporterte tapene skyldes rovvilt (Tveraa mfl., 2013). Konklusjonen var ikke i tråd med det næringen selv mente var den viktigste tapsårsaken (Nordlys, 2013). Landbruks- og matdepartementet, Klimaog miljødepartementet og Miljødirektoratet hadde finansiert prosjektet.

Resultatene av denne forskningen ble presentert i en artikkel i papirutgaven av Dagens Noringsliv i juni 2013. Saken ble slått stort opp med dobbeltsidig artikkel og forsiden av avisa med teksten «Dør av sult - eierne får rovvilterstatning» (Dagens Næringsliv, 2013). Vi valgte å presentere forskningen i en riksavis for å nå bredt ut med det våre forskere mente var viktige forskningsresultater. Temaet var svært relevant for reindriften, landbruks- og miljøforvaltningen, og hadde ved flere tidligere 
anledninger vært presentert i riksdekkende medier. Responsen ble imidlertid atskillig mer omfattende denne gangen. I ukene etter publiseringen ble rapporten gjenstand for mer enn 150 norske medieoppslag. I noen av avisinnleggene ble NINAs forskning blant annet kalt bestillingsverk og useriøs forskning (Nordlys, 2013; Dagens Næringsliv, 2013). Forskerne svarte på nesten alle innleggene med faglige og saklige innlegg som forklarte forskningen og det datagrunnlaget resultatene bygget på. Også det internasjonale fagtidsskriftet Science fant det interessant å referere saken ut fra diskusjonen i norske medier (Kintisch, 2014). Debatten i de tradisjonelle mediene varte gjennom sommeren, og roet seg utover høsten. Dog foregår den fortsatt i sosiale medier.

I ettertid gjennomførte vi en intern evaluering av innsatsen. Forskerne stod stødig i mediestormen, godt støttet av kolleger og ledelsen, og med praktisk bistand fra NINAs kommunikasjonsenhet. Et viktig mål for NINA er at resultatene fra forskningen blir tatt i bruk og kommer til nytte. For å oppnå det er aktiv formidling av dem nødvendig. Vi konkluderte derfor med at vi fikk formidlet forskningsresultatene bredt, og at hovedfunnene kom tydelig fram. Samtidig så vi at funnene våre, uansett vinkling eller presentasjonsform, ville ha skapt debatt. Avisoppslaget i Dagens Noringsliv, med en såpass heftig forside, genererte nok ekstra temperatur i saken. Men samtidig ser vi at den ble starten på en effektiv og kontrollerbar formidling av det viktige budskapet. Ett av punktene som ble understreket sterkest i evalueringen, er betydningen av god intern organisering og kommunikasjon - både med hensyn til faglig arbeid og når det gjelder omsorg og støtte til dem som fronter saken.

Forvaltning av reindriften, reintallsreduksjon og tapsårsaker blir kontinuerlig debattert både lokalt, regionalt og nasjonalt. Kritiske spørsmål om kunnskapsgrunnlaget kommer opp med jevne mellomrom, men både intensiteten og innholdet i kritikken er ikke i nærheten av opplevelsene fra sommeren 2013 .

\section{Brysom villaks}

Lenge før NINA ble skilt fra staten i 1988, og stiftelsen NINA ble opprettet, har forskning og overvåking av bestandsutviklingen hos villaks vært 
et kjerneområde for oss. Forskning på ulike trusselfaktorer for villaksen har stått sentralt. NINA har høy kompetanse på effekter av vannkraft og andre fysiske inngrep i vassdrag, sur nedbør, klimaendringer, lakseparasitten Gyrodactylus salaris og havbruk. Mer enn 50 forskere arbeider med ulike temaer knyttet til vill laksefisk, og vi legger stor vekt på vitenskapelig publisering i journaler med fagfellevurdering. I 2011 ble NINAs biologiske forskning evaluert som del av Forskningsrådets fagevaluering av biologisk forskning i Norge. Det internasjonale panelet som evaluerte kompetanse og produksjon, uttrykte følgende om fagmiljøet på vill laksefisk: «The Aquatic Ecology unit is considered world-class with regard to research on anadromous salmonids» (Forskningsrådet, 2011).

Norge har om lag 440 lakseelver, som hver har sin egen laksestamme. Antallet ville laks som kommer tilbake fra sjøen for å gyte hvert år, er nå om lag 500 ooo individer, noe som er mer enn en halvering fra 1983 til 2015. Dette skyldes delvis at laksen har lavere overlevelse i sjøen nå enn den hadde på 1980-tallet. Hvem eller hva som har skylda for lav sjøoverlevelse, og hva som kan gjøres for å bøte på dette, er vanskelig å vurdere. Det vi imidlertid vet, er at lakseoppdrett - med rømt oppdrettslaks og økt produksjon av lakselus - vurderes til å være de faktorene som har påvirket flest laksebestander negativt de senere årene. I ferskvann er vannkraftregulering den faktoren som påvirker flest bestander. At vannkraft påvirker laksebestandene negativt, er anerkjent i kraftbransjen, og vannkraftregulantene utfører en rekke tiltak for å kompensere for de negative effektene. Det har vist seg langt mer utfordrende å få en samlet oppdrettsnæring til å anerkjenne miljøutfordringen og konsekvensene av det økologiske fotavtrykket som næringen setter. I 2015 ble det produsert om lag 1,3 millioner tonn oppdrettslaks i Norge. Samme år ble det rapportert om 160 ooo laks på rømmen. Dette tilsvarer en tredjedel av villaksen som kommer tilbake til elvene for å gyte (Anon., 2016).

Allerede på slutten av åttitallet fant forskere høye innslag av rømt oppdrettslaks i flere elver. I 1991 ble det påvist at de formerte seg med villaks (Lura \& Sægrov, 1991), noe som kunne påvirke de genetiske særtrekkene til de 440 ulike laksestammene i Norge (Hindar mfl., 1991). Funnene var allerede da omstridt. Som følge av formidabel vekst i produksjonen av oppdrettslaks de neste tjue årene økte også miljøproblemene. Forskerne 
fant særlig økte mengder lakselus, med negative effekter på laks og sjøørret. I 2009 formidlet NINA-forskerne at mengden lakselus i oppdrettsanleggene virket å være ute av kontroll, og varslet om at denne utviklingen kunne få store konsekvenser for vill laksefisk. Siden den gang har mange forskningsresultater og vitenskapelige publikasjoner bekreftet de uheldige effektene av lakselus og rømt oppdrettslaks (Thorstad mfl., 2015; Karlsson mfl., 2016; Vollset mfl., 2016; Bolstad mfl., 2017; Glover mfl., 2017).

Disse forskningsresultatene setter begrensninger for veksten i oppdrett langs norskekysten, og følgelig er denne kunnskapen meget upopulær. Forskningsresultatene bidrar også til å forsterke konfliktene mellom villaksinteressene og oppdrettsinteressene.

Det begynte med en diskusjon om omfanget av rømt oppdrettslaks i Altaelva. På forespørsel kommuniserte NINA i desember 2010 foreløpige resultater til den lokale grunneierorganisasjonen. Resultatene ble slått opp i media på grunn av stor interesse i forbindelse med politiske prosesser knyttet til vekst i næringa. Nesten to år etter, i mars 2012, ble saken plutselig omtalt på nettstedet Kyst.no. En lokalpolitiker i en sentral oppdrettskommune i Sør-Trøndelag formidlet i sterke ordelag at han ikke stolte på NINA og deres forskere på grunn av medieoppslagene i 2010 (Kyst.no, 2012). Vi tok da initiativ til et oppklaringsmøte hvor denne personen og andre sentrale fylkespolitikere deltok. Det var et godt møte, og vi trodde at saken var oppklart og ute av verden (Kyst. no, 2012).

Like etter dette, i april 2012, fikk jeg en e-post fra den samme lokalpolitikeren. Der hevdet han at forskerne i NINA hadde misbrukt sine stillinger da de i 2010 leverte forskningsresultatene fra Altaelva, som viste negative effekter av oppdrett, samtidig med at fiskeriministeren skulle avgjøre om det skulle tillates videre vekst i oppdrettsnæringen i Finnmark. E-posten inneholdt blant annet et konkret krav om at navngitte forskere skulle avsettes eller gis andre oppgaver i NINA. FiskeribladetFiskaren omtalte saken på lederplass i november samme år (FiskeribladetFiskaren, 2012). De beskrev dette som et eksempel på den verste formen for maktutøvelse av en folkevalgt. I håp om at konflikten med lokalpolitikeren ville roe seg, valgte jeg å legge e-posten til side. Situasjonen var ganske rolig fram til 2015. 
I juni i 2015 publiserte den samme personen, som da var blitt fagsjef $\mathrm{i}$ Norske Sjømatbedrifters Landsforening (NSL), en kronikk i Adresseavisen med overskriften «Tvilsomt samrøre i norsk lakseforskning» (Adresseavisen, 2015). I kronikken ble det hevdet at NINA fikk betalt av vannkraftbransjen for å underslå kraftindustriens miljøpåvirkning. Videre framsatte han påstander om at NINA-forskere som har oppdrag fra flere oppdragsgivere, syr sammen forskningsresultater for å sverte oppdrettsnæringen. Adresseavisen ga NINA tilsvarsrett til kronikken. Vi vurderte saken som såpass kompleks, og kronikken så konspiratorisk i formen, at vi valgte å skrive et lengre innlegg på egen nettside hvor vi både forsvarte forskningen vår, og forklarte hvordan forfatteren av kronikken hadde blandet ulike saker og trukket helt feil slutninger. Vi beskrev beskyldingene fra NSL som usaklige (NINA.no, 2015). Dette innlegget resulterte i et avisoppslag i nettavisa iLaks.no med intervju av stortingspolitiker Ove Trellevik, som karakteriserte NINAs innlegg som «Skivebom fra NINA» (iLaks.no, 2015). Gjennom resten av 2015 og i 2016 ble det publisert flere titalls innlegg på Facebook-gruppene «Villaksens venner» og «Ja til oppdrettslaks og arbeidsplasser langs kysten» med påstander om juks og korrupsjon i lakseforskninga og beskrivelser av NINA-forskere som lot seg kjøpe. I en del diskusjonstråder ble også enkeltforskere i NINA navngitt og hetset. Innleggene var til dels svært usaklige, og noen direkte sjikanøse. Både innholdet i meldingene, det store antallet meldinger og at dette hadde pågått over lang tid, gjorde situasjonen svært ugrei for oss. Vi valgte å gå til media, og Dagens Noringsliv trykket saken i mars 2016, der vi varslet at vi vurderte å gå til rettslige skritt (Dagens Næringsliv, 2016). I samme avis publiserte undertegnede og direktør Sissel Rogne ved Havforskningsinstituttet en felles kronikk med tittelen «Frykt for forskning», hvor vi tok til motmæle mot usaklig kritikk fra deler av oppdrettsnæringen (Dagens Næringsliv, 2016). Etter dette roet usaklighetene og sjikanen på sosiale medier seg.

Neste runde startet allerede i mars 2016, med innsynsbegjæringer etter miljøinformasjonsloven fra Advokatfirmaet Steenstrup Stordrange. Innsynsbegjæringen rettet seg mot NINAs forskningsstasjon, som vi hadde tilbudt til miljøforvaltningen som lokasjon for ny genbank for vill laksefisk fra Hardangerfjorden. Behovet for en genbank oppstod som 
følge av påvirkning av oppdrettsfisk på vill laks og sjøørret i Hardangerfjorden. NINA er en privat stiftelse i et marked med konkurranse om oppdrag, og er ikke omfattet av offentlighetsloven. Dette påvirker også vårt forhold til miljøinformasjonsloven, gjennom at kravene til utlevering blir noe begrenset. NINA ønsker imidlertid å være en åpen institusjon, selv om lovverket ikke krever det, og vi legger alltid opp til å dele forskningsresultater og metoder. Begjæringen var imidlertid ikke rettet mot forskningsresultater, men mot de ulike tillatelsene som kreves for å drive en forskningsstasjon med levende fisk. Vi ble bedt om å oversende alt av offentlige tillatelsesgrunnlag helt tilbake til 1973 (iLaks.no, 2016). Advokatkontoret ville ikke opplyse hva de skulle bruke dette materialet til, og heller ikke hvem oppdragsgiverne var. Vi oversendte etter hvert en omfattende samling dokumenter som bekreftet at vi hadde alle tillatelser i orden. Senere samme år kom en ny henvendelse fra samme advokatfirma - med påstand om at NINA er underlagt offentlighetsloven, og dermed også arkivloven. Begrunnelsen var at mer enn halvparten av NINAs styre er oppnevnt av offentlige organer. NINA fikk utarbeidet en juridisk betenkning fra Abelia (NHO), som fastslo at vi ikke var omfattet av dette lovverket, med den begrunnelsen at NINA var i en konkurransesituasjon med private aktører. Betenkningen ble oversendt advokaten ved årsskiftet 2016/17. Advokaten bad videre om ytterligere dokumentasjon på hvor inntektene våre kom fra, inkludert opplysninger om konkurransesituasjonen vår. I januar 2017 ble derfor ytterligere dokumentasjon om NINAs konkurransesituasjon oversendt advokaten.

Jeg har her beskrevet ulike hendelser gjennom fem lange år. Redegjørelsen er langt fra komplett, men gir et bilde av ulike aktiviteter som kan oppleves å ha som mål å sverte en forskningsinstitusjon som leverer aktuell og relevant kunnskap, kunnskap som for noen er upopulær. Utallige advokathenvendelser og innsynsbegjæringer i gamle saker hvor det for oss var umulig å skjønne hensikten med, opplevdes også som en aksjon for å binde opp ressurser til andre oppgaver enn forskning. Kjerneoppgaven til NINA er å levere forskning og kunnskap til nytte for samfunnet. Aktørene har lagt ned en stor innsats i å angripe forskere, spre konspiratoriske teorier om NINA og lete etter feil fra vår side. 


\section{Hva må forskeren like - og tåle?}

Hva gjør så denne typen kritikk og angrep med forskerne? I et forskningsetisk perspektiv er det viktig å være oppmerksom på om dette påvirker deres evne og lyst til å formidle forskningsresultater. Som arbeidsgiver må jeg også se det i et arbeidsmiljøperspektiv.

Forskeren må like å formidle forskningen sin. Det bidrar til at resultater lettere blir tatt i bruk. Dette kan utløse midler til ny forskning, og gir ofte forskeren inspirerende tilbakemeldinger som igjen danner grobunn for nye ideer og prosjekter. God formidling bygger også godt omdømme for forskeren og forskningsinstituttet. Forskningsformidling er dessuten et meget viktig element $\mathrm{i}$ forskernes akademiske frihet.

Forskere som arbeider på fagfelt hvor det er interessekonflikter, må kunne håndtere at det i perioder stormer rundt forskningen. Jeg erfarer at forskere både gleder seg og gruer seg til å presentere nye funn. De gleder seg til å fortelle om forskningsresultater som har betydning for viktige spørsmål i samfunnet. At media svært gjerne vil skrive om saken og intervjue forskere, oppleves som inspirerende. Samtidig erfarer jeg at de gruer seg til kritikk og usakligheter som de av erfaring vet kan komme. I slike saker stilles det ekstra krav både til forskerne og til arbeidsgiveren, og det er avgjørende at forskerne er forberedt på hva som kan komme av kritikk. De må ha et godt apparat rundt seg av kolleger, ledelse og fagfolk med spesialkompetanse innen kommunikasjon.

Jeg opplever at erfarne og faglig sterke forskere, med god rolleforståelse og god kjennskap til interessekonfliktens ulike aktører og interesser, tåler godt å stå i stormen i en periode. De tør også å innrømme og forklare eventuelle usikkerheter i datamaterialet, samtidig som de med autoritet formidler viktige funn og trender.

Mange av NINAs forskningsområder preges av interessekonflikter. Det er knyttet sterke faglige og økonomiske interesser til havbruk og villaks, vannkraft, rovvilt og beitedyr. Økonomiske interesser, verneinteresser og konsekvenser for enkeltmennesker eller grupper er en fellesnevner her. Vi opplever et krevende politisk landskap rundt disse forskningsområdene - med næringspolitiske mål om vekst og økt lønnsomhet, samtidig som bærekraft og bevaring av naturmangfold skal ivaretas. 
NINA har som prioritert mål at forskningsresultater skal formidles aktivt til brukere og publikum. Vi har en intern «Vær-bevisst-plakat» for forskningsformidling - med klare råd til forskerne i kommunikasjonsarbeidet. Det er forskeren som formidler, og det er forskeren som må stå i stormen når det oppstår konflikter om resultater og kunnskapsgrunnlag.

Interessekonflikter og kritikk av forskning er ikke bare negativt; bildet er mer nyansert enn det. Forskerne melder at kritikken er skjerpende og bidrar til at de gjør en enda grundigere jobb. De jobber ekstra nøye med formuleringer, og de bruker forskere både fra egen institusjon og hos samarbeidspartnere til kvalitetssikring. Når stormen kommer, står de stødig på formuleringene og bruker forskerkollegene som sparringpartnere i håndteringen av kritikken. De opplever også en ekstra motivasjon til å publisere i vitenskapelige journaler. Her blir både kvalitet på data, metodevalg og resultater grundig fagfellevurdert. Fagfellene er ofte utenlandske eksperter som må skrive under på at de ikke har personlige interesser knyttet til forskningen de skal evaluere. Samtidig er redaktørene eksperter med god kjennskap til fagfeltet. Vitenskapelig publisering er avgjørende for at forskeren skal ha faglig autoritet og selvtillit i den offentlige diskusjonen.

Det er imidlertid grenser for hva forskerne skal måtte finne seg i. Systematisk sjikane og alvorlige beskyldninger om juks og korrupsjon er ikke akseptabelt, og kan være uutholdelig for dem som blir anklaget. Sosiale medier har gjort det lettere å kritisere forskning, forskere og forskningsinstitusjoner. Ordbruken er krassere, og nettroll bidrar til å nøre opp under konfliktene. Vedvarende og systematisk usaklig kritikk kan gå ut over forskernes jobbutøvelse, privatliv og viljen til å la seg oppnevne i ekspertutvalg og andre rådgivende organer. Vedvarende og systematisk usaklig kritikk kan i verste fall føre til at forskerne blir defensive, og de kan føle at deres akademiske frihet blir truet. Slik kan det oppstå en feilaktig oppfatning om at kunnskapsgrunnlaget er svakt. Resultatet kan bli at den allmenne tilliten til forskere og forskningsresultater svekkes. Dette kan igjen føre til at viktig kunnskap ikke når fram til politikere og andre målgrupper, og at beslutninger fattes på feil grunnlag. 


\section{Machoforskeren}

Ikke alle forskere er robuste nok til å forske på de mest konfliktfylte fagområdene. Er dette bare for «machoforskeren»? Vedkommende må ha bred faglig oversikt, solid vitenskapelig merittliste, stort faglig nettverk og god oversikt over aktørbildet. Og han må være hardhudet og tåle en trøkk. Jeg skriver han, fordi vi ser at arenaen av forskere som står i stormen, domineres av menn (Morgenbladet, 2017; Harvest, 2017). Spørsmålet er om de mest opphetede interessekonfliktene vil påvirke hvilken retning unge akademikere velger? Vil kvinner og menn velge ulikt? Ved rekruttering av nye forskere ser vi alltid etter de beste, og vi må samtidig sikre at de er robuste nok til å tåle skarpe diskusjoner.

I alle saker som gjelder naturressurser, er det forståelig at enkelte aktører stiller spørsmål ved kunnskapsgrunnlaget fordi forskningsresultatene berører og kan ha store økonomiske eller samfunnsmessige konsekvenser. Jeg anerkjenner at ulike interessenter er viktige voktere og kritikere av forskning. Vi blir da minnet om at forskning er viktig, og at kunnskap er makt. Det er dette spenningsfeltet som gjør anvendt naturforskning aktuell, og som sikrer at kunnskapen vi bidrar med, er etterspurt i samfunnet. Samtidig er jeg ydmyk over at forskningsresultatene kan ha store konsekvenser for både næringer, lokalsamfunn og enkeltpersoner.

Forskningsformidling er viktig, ikke bare via vitenskapelige kanaler, men også i det offentlige rom. Det er når konfliktene om kunnskapsgrunnlaget får stor tyngde og stort omfang, at det stilles ekstra krav til forskere og arbeidsgiver. Forskeren må forvalte rollen sin med faglig integritet, klokskap og god rolleforståelse, med støtte fra sin arbeidsgiver. Jeg er også tilfreds med å se at både forskningsetiske komiteer og forskernes egne fagforeninger reiser spørsmål og tar aktivt del i diskusjonen om hvordan forskning og forskere blir behandlet i de mest opphetede debattene.

Det er avgjørende at den enkelte forsker ikke blir stående alene i stormen. I NINA har vi en praksis der vi etablerer en beredskapsgruppe bestående av berørte forskere, forskningssjef, kommunikasjonssjef og administrerende direktør. I perioder med høyt konfliktnivå har vi gjerne daglige møter. Dette er en helt nødvendig arena, hvor vi i fellesskap utvikler strategier for hvordan vi skal håndtere situasjonen. 
I begge eksemplene mine har konfliktene pågått over flere år. I eksempelet med havbruk har konflikten vært ekstra omfattende, og da blir det langt mer krevende å holde ut. Jeg har stor respekt for - og føler også et ansvar for - forskere som må stå i slike situasjoner over lang tid. Samtidig er jeg opptatt av at den usaklige kritikken ikke skal gjøre oss defensive og redde. Som arbeidsgiver har jeg en viktig rolle i å støtte, og om nødvendig beskytte, forskerne for å unngå at arbeidssituasjonen blir en for stor personlig belastning. I havbrukssaken valgte vi etter en tid å ta bladet fra munnen og ytre oss offentlig om selve konflikten. Advokathenvendelsene ble håndtert administrativt i NINA, med støtte fra vår egen bransjeorganisasjon Abelia.

\section{Tiltak}

Som arbeidsgiver har naturligvis mitt hovedperspektiv vært arbeidsgiveransvaret og de etiske sidene ved at forskernes akademiske frihet og plikt kan bli svekket. Det er mange som har aksjer i problemstillingene jeg har reist, særlig fordi de påvirker demokratiske prosesser når viktige beslutninger skal fattes. Politikere, forvaltning, næringsinteresser og organisasjoner, journalister, Norges forskningsråd, de forskningsetiske komiteene og fagforeningene må alle være bevisst på problemstillingene og konsekvensene de kan ha. Universitetenes ansvar er å bidra til at den faglige og forskningsetiske grunnmuren til studentene blir robust nok til å takle utfordringene som den anvendte forskningen av og til står overfor.

Det har vært diskutert om Norge trenger et nasjonalt råd for vitenskap som kan fortelle politikerne og andre beslutningstakere hva som er den sikreste og beste kunnskapen innenfor aktuelle saker (Morgenbladet, 2016). Jeg ville ønsket et slikt nasjonalt råd velkommen - dersom jeg hadde vært sikker på at det kunne løst utfordringene med usaklig kritikk og sjikane av forskere, og sikret at upopulær kunnskap ble håndtert like respektfullt som populær kunnskap. Interessekonfliktene på ulike forskningsfelt er mange og til dels svært ulike, og derfor betviler jeg at et nasjonalt råd vil kunne håndtere dette bedre enn det forskningsinstitusjonene gjør i dag. En del av problemstillingene er særnorske, og følgelig måtte utvalget fortrinnsvis bestå av norske eksperter. Norge er et lite land, 
og det finnes få eksperter som ikke allerede er involvert i de ulike fagområdene. Vitenskapskomitéen for mat og miljø og Vitenskapsrådet for lakseforvaltning ligger begge innenfor NINAs fagområder. Deres mandat er blant annet å oppsummere og gi råd ut fra all tilgjengelig forskning i de aktuelle spørsmålene. Et viktigere tiltak vil derfor være å sikre at det på kompliserte og konfliktfylte fagfelt settes sammen forskergrupper på tvers av sektorer og instituttgrenser. I tillegg må NENT fortsette å vokte de forskningsetiske aspektene ved interessekonflikter i forskning, blant annet gjennom å sette temaet på dagsordenen i det offentlige rom. Jeg registrerer også med tilfredshet at det etter hvert er etablert en rettspraksis knyttet til hets og sjikane på nett.

Jeg erkjenner at forventningene mine til beslutningstakere og journalister om at de skal validere kunnskapen de får, er høye forventninger. Enkle og lettfattelige rapporter som er skrevet av en interessent i en konflikt, kan være langt lettere å forstå og bruke enn vitenskapelige publikasjoner og tunge forskerrapporter hvor både teori og empiri presenteres og diskuteres. I den senere tid er det også pekt på at interessen for å hente råd fra eksperter og kunnskapselite er blitt mindre (The Guardian, 2016). Det stilles også spørsmål ved om tilliten til forskerne og forskningsresultater er lavere enn den burde være (Forskningsrådet, 2017). Dette er en utfordring som forskningen selv må ta på største alvor. Forskerne må utøve god og solid kommunikasjon slik at vanlige folk forstår hva de har forsket på, hva de har funnet, og hva resultatene kan brukes til. For forskerne i NINA betyr det at vi må fortsette å delta på folkemøter og seminarer for å treffe brukerne - som på godt og vondt blir berørt av våre forskningsresultater.

\section{Konklusjon}

Diskusjon om forskningsresultater i det offentlig rom viser at forskningen er relevant. Robuste forskere med god faglig innsikt og integritet tåler en trøkk når arbeidsgiver og gode kolleger støtter opp om dem. Dette lever vi med - og av. For paradokset er at ved interessekonflikter og diskusjon om kunnskapsgrunnlaget utløses ofte mer forskningsmidler som det kan søkes på. 


\section{Referanser}

Adresseavisen (2015). https://www.adressa.no/meninger/kronikker/article11184310. ece

Anon. (2016). Status for norske laksebestander i 2016. Rapport fra Vitenskapelig råd for lakseforvaltning.

Bolstad, G., mfl. (2017). Gene flow from domesticated escapes alters the life history of wild Atlantic salmon. Nature Ecology \& Evolution, 1: 0124.

Dagens Næringsliv (2013). https://www.dn.no/nyheter/politikkSamfunn/2013/o6/21/ matmangel-og-sult-tar-livet-av-reinen

Dagens Næringsliv (2013). http://www.umb.no/statisk/noragric/publications/media/ Benjaminsen_Kronikk_DN_050713.pdf

Dagens Næringsliv (2016). https://www.dn.no/nyheter/ politikkSamfunn/2016/03/15/2031/Havbruk/-dette-m-ta-slutt

Dagens Næringsliv (2016). https://www.dn.no/meninger/debatt/2016/03/15/2143/ Oppdrett/frykt-for-forskning

FiskeribladetFiskaren (2012). https://fiskeribladet.no/nyheter/?artikkel=29156

Forskningsrådet (2011). Evaluation of biology, medicine and health research in Norway, panel 1.

Forskningsrådet (2017). https://www.forskningsradet.no/no/Nyheter/_Flere_ma_ta_ ansvar/1254029137944/p1174467583739

Glover, K.A., mfl. (2017). Half a century of genetic interaction between farmed and wild Atlantic salmon: Status of knowledge and unanswered questions. Fish and Fisheries: 1-38.

Harvest (2018). http://harvest.as/artikkel/sjomatnasjonen-norge-forskere-underpress

Hindar, K., mfl. (1991). Genetic effects of cultured fish on natural fish populations. Canadian Journal of Fisheries and Aquatic Sciences, 48: 945-957.

Dagens Næringsliv (2016). https://www.dn.no/meninger/debatt/2016/03/15/2143/ Oppdrett/frykt-for-forskning

iLaks.no (2015). https://ilaks.no/skivebom-fra-nina/

iLaks.no (2016). https://ilaks.no/havforskere-foler-seg-terrorisert/

Karlsson, S., mfl. (2016). Widespread genetic introgression of escaped farmed Atlantic salmon in wild salmon populations. ICES Journal of Marine Science, 73: 2488-2498.

Kintisch, E. (2014). What's killing the reindeer? Science 346(6210): 685.

Kyst.no (2012). http://kyst.no/nyheter/reppe-trur-ikkje-p-hindar-si-forklaring/

Kyst.no (2012). http://kyst.no/nyheter/leiinga-i-nina-reagerer-sterkt-p-utspel-frreppe/

Landbruksdirektoratet (2016). Ressursregnskap for reindriften 2015-2016. 
Lura, H., \& Sægrov, H. (1991). Documentation of successful spawning of escaped farmed female Atlantic salmon, Salmo salar, in Norwegian rivers. Aquaculture, 98: 151-159,

Morgenbladet (2016). https://morgenbladet.no/aktuelt/2016/og/hoyre-er-lei-avunyttig-forskning

Morgenbladet (2017). https://morgenbladet.no/aktuelt/2017/o6/de-forbannedelakseforskerne

NINA.no (2015). https://www.nina.no/Aktuelt/Nyhetsartikkel/ArticleId/3845/ Usaklige-beskyldninger-fra-Norske-Sjomatbedrifters-Landsforening-NSL

Nordlys (2013). https://www.nordlys.no/nyheter/reinen-ble-drept-av-rovdyr-men-iforskerens-rapport-sultet-den-i-hjel/s/1-79-6723804

Nordlys (2013). https://www.nordlys.no/nyheter/benekter-at-omstridt-rapport-erbestillingsverk/s/1-79-6736176

The Guardian (2016). https://www.theguardian.com/commentisfree/2016/dec/o1/ stephen-hawking-dangerous-time-planet-inequality

Thorstad, E.B., mfl. (2015). Effects of salmon lice Lepeophtheirus salmonis on wild sea trout Salmo trutta-a literature review. Aquaculture Environment Interactions, 7: 91-113.

Tveraa, T., mfl. (2013). Beregning av produksjon og tap i reindriften. NINA Rapport 938.

Vollset, K.W., mfl. (2016). Impacts of parasites on marine survival of Atlantic salmon: A meta-analysis. Fish and Fisheries, 17: 714-730. 


\title{
Styrke og veiledning: Forskningsformidling i møte med særinteresser
}

\author{
Bjørn H. Samset \\ Fysiker, klimaforsker og fagformidler ved CICERO Senter for \\ klimaforskning
}

\begin{abstract}
Why do people increasingly reject science in favor of subjective opinion? This well-known trend, most recently embodied as "fake news", has both put lives at risk (through the increasing support for the anti-vaccine movement) and delayed the necessary global adoption of green energy (through so-called climate change skepticism). In this article, I show how rejection of science is often linked to a particular type of new knowledge, one where scientific advice does not grant us local, immediate gains. I also investigate societal megatrends that underlie such skepticism: the growth of social media, the rapid pace of headline news, and the enormous expansion of science itself. Finally, I discuss a way to combat "fake news" and its related phenomena, through more dedicated science communication. "Strength and guidance" is a good slogan for the disseminators of today and tomorrow; strength because the core messages from science need to be ever repeated in a world hungry for sensations, and guidance because the world has grown so complex that bare facts are no longer sufficient. Science communicators need to step out of their comfort zone and give actual, science-based advice - and still refrain from crossing the fine line between objectivity and activism.
\end{abstract}

Keywords: communication, skepticism, fake news, social media, megatrends, public understanding of science

\section{En ny type fagformidler}

Forskning har aldri vært viktigere enn i dag. Fremskritt innen natur- og samfunnsvitenskap har lagt grunnlaget for det moderne samfunnet, men også bidratt til en verden der syv milliarder mennesker står overfor store

Sitering av dette kapitlet: Samset, B.H. (2019). Styrke og veiledning: Forskningsformidling i møte med særinteresser. I H. Ingierd, I. Bay-Larsen \& K. Hiis Hauge (Red.), Interessekonflikter i forskning (s. 231-251). Oslo: Cappelen Damm Akademisk. https://doi.org/10.23865/noasp.63.ch11 Lisens: CC BY 4.0 
felles utfordringer. Ny, sikker kunnskap er brennende nødvendig. Derfor er det forstemmende å se hvordan forskning og vitenskapelig metode tilsynelatende stadig oftere avvises i det offentlige ordskiftet, til fordel for subjektive meninger.

Har veien fra forskning til anvendelse blitt så lang at folk har mistet tilliten? Eller har begrepet «forskning viser» blitt så systematisk misbrukt i interessekonflikter mellom særinteresser, at ingen lenger vet hva de kan stole på?

Undersøkelser bekrefter dette inntrykket. Tilliten er dalende, både til forskning og til forskerne selv. De er kjøpt og betalt. Et akademisk ekkokammer, til og med en konspirasjon. Konklusjonene deres må avvises, og alternative synspunkter må få slippe til. Det vitenskapelige prinsippet om evidensbasert argumentasjon ut fra fagfellevurdert litteratur må vike for samfunnsnormer som ytringsfrihet og respekt for mindretallet.

Hvor kommer denne trenden fra? Ulvedebatten, vaksinemotstand, biodrivstoff, el-overfølsomhet og spesielt menneskeskapte klimaendringer er temaer hvor vitenskapens brede konklusjoner ofte avvises. Hva gjør vi - som forskere og akademikere - når konklusjonene vi formidler, avfeies med referanser til subjektive oppfatninger? Er motstanden en styrke for den offentlige debatten, fordi den får frem flere sider av en sak? Eller er den en farlig trend som undergraver respekten for forvalterne av samfunnets kunnskapsgrunnlag? Og når tvilen først er gitt en stemme, hvordan avgjør folk hvem som er «eksperter», og hvem som bare uttaler seg subjektivt? Har ekspertene alltid rett?

I denne artikkelen skal vi se at fremveksten av såkalte postfakta - eller avvisning av vitenskap, med henvisning til subjektive oppfatninger - i noen tilfeller kan utgjøre et stort problem. Samtidig springer problemet ut av megatrender i samfunnet som vi ellers regner som goder, og som vi dermed ikke så lett kan bli kvitt. Forskningen har også et ansvar selv.

For å få bukt med utfordringene må vi først bli bevisst på hvor - i møtet mellom ny kunnskap og samfunnet - motstanden dukker opp. Vi har lært oss å være skeptiske til reklame, og til politikeres valgkampløfter. Her skal vi se at vi bør anta en tilsvarende skepsis til polemikken som oppstår når fersk forskning kommer med inngripende råd som ikke gir oss umiddelbare fordeler. Vi skal dele kunnskap inn i fire kategorier: 
«wow», «kjekt å vite», «for mitt eget beste» og «altruistisk». Det er i den siste kategorien, som inneholder både vaksiner og klimaendringer, at konflikten mellom vitenskap og særinteresser oftest står. "Altruistisk» kunnskap, som primært appellerer til vårt felles beste, er kritisk for samfunnet, men ekstremt vanskelig å få aksept for. Vi skal se hvordan den naturlig motvirkes av en rekke moderne trender.

Vi skal også vurdere en bredere strategi for kommunikasjon. I stedet for klassiske formidlere, som har tenkt at om de bare fyller tomme hoder med kunnskap, vil folk handle rasjonelt deretter (Sturgis \& Allum, 2004), må vi gi plass for en formidlertype som definerer sin rolle nærmere det offentlige ordskiftet (Corner \& Groves, 2014). «Styrke og veiledning» kan være et passende slagord. Styrke, fordi dagens mediebilde krever at de samme budskapene må gis igjen og igjen. Veiledning, delvis fordi dette er hva informasjonstrette mediebrukere gjerne ønsker seg, men mest fordi det er nødvendig for å opprettholde tilliten til forskning i det lange løp.

Slik formidling kan være både uvant og kontroversiell. Vi har dyrket et ideal av forskerens rolle i offentligheten som absolutt objektiv. En klassisk fagformidler er en referent av etablerte fakta, og tar ikke tar stilling til hvordan kunnskapen bør anvendes. Men veiledning grenser av natur mot det subjektive. Skal samfunnsdebatten føres på et solid grunnlag, er noen formidlere nødt til å gå lenger i en slik retning enn de har gjort tidligere. Enten vi liker det eller ikke, må forskere ikle oss en ny offentlig rolle. Hvis ikke mister vi raskt vår kritiske - men skjøre - posisjon som forvaltere av samfunnets kunnskapsgrunnlag. Den vitenskapelige metode fungerer, men er langt fra intuitiv. Forskerne ER ekspertene, men vi kan ikke forvente å få den rollen i fanget bare fordi vi kan skilte med doktorgrader og artikler i tidsskriftene Science og Nature.

\section{Når skepsis leder til skade: Vaksiner og klima}

Kan det skade at forskningens konklusjoner møter motstand? Ja, i noen tilfeller. Forskning må tåle å bli avkrevet forklaringer og begrunnelser, men det er ikke det samme som å møte organiserte angrep og tvil satt i system.

27. april 2017 la tidsskriftet Science ut nyhetssaken «Here's the visual proof of why vaccines do more good than harm» (Science, 2017). En flott 
infografikk viser tidsutviklingen i antall tilfeller av en rekke sykdommer - difteri, polio, meslinger, kikhoste og mange flere - og vaksinasjonsprogrammene mot dem. Før vaksinene er det mange sykdoms tilfeller. Etterpå er det få eller ingen. Selv om korrelasjon ikke nødvendigvis innebærer kausalitet, skal det godt gjøres å ikke lese av denne infografikken at vaksiner beskytter mot farlige sykdommer. Og tviler man likevel, gir den lenker til over to hundre år med forskning.

Grunnen til at selveste Science likevel lager en slik grafikk, i år 2017, finner vi i begrepet «antivax». En motbevegelse, gammel som vaksinebegrepet selv, der kritikere stiller spørsmål ved om vaksinering faktisk har en effekt, og om nytten av dyre nasjonale eller globale programmer. Dagens antivax-ere hevder gjerne å være forskningsbaserte. De overser systematisk de positive effektene, og trekker isteden frem fagfellevurderte studier som antyder at vaksinene også kan ha skadevirkninger. Det mest kjente eksemplet er en forskningsartikkel fra 1998 i The Lancet, der medisineren Andrew Wakefield hevdet å ha funnet en sammenheng mellom vaksinering og autisme hos barn. Problemet er bare at forskningen senere ble avslørt som fusk, i et av de mest dramatiske eksemplene på fabrikkerte resultater innenfor moderne medisin. Men at Wakefield-saken har nådd klisjéstatus i artikler om feilaktig bruk av forskning, hindrer ikke antivax-bevegelsen i å bruke den som bensin til sine vitenskapskritiske bål.

Vaksinemotstand er et eksempel på en skjæringsflate mellom forskning og samfunn, der et samlet forskerkorps gir en beskjed («vaksiner er trygge, og kritisk viktige for helsen vår»), mens store grupper av «folk flest» mener noe annet («vaksiner er farlige, og derfor skal ikke mitt barn vaksineres»). Ofte trekkes diskusjonen helt ned på individnivå («mitt barn er spesielt utsatt for bivirkninger»). Hvor skadelig er slik motstand? I mange andre tilfeller ville en kunne hevde at utfordringen mest ligger i formidling, og at infografikk som den i Science vil kunne hjelpe. Men vaksiner er spesielle. Om en enkelt familie vaksinerer seg mot en smittsom sykdom, så hjelper det dem, men ikke så mange andre. Først når så å si alle i et lokalsamfunn er vaksinert, får vi full effekt. Da finner ikke sykdommen nye verter å spre seg til, og de få som ikke er vaksinert, blir også beskyttet.

Men hva skjer hvis en oppnår slik gruppeimmunitet, men at en stadig større gruppe så lar være å vaksinere seg? Da kan sykdommen få nok 
potensielle verter, og igjen begynne å spre seg. Nettopp dette ser vi i dag (BBC, 2017). Gruppeimmunitet krever at minst $95 \%$ av befolkningen er vaksinert. Den vestlige verden har lenge vært over dette tallet, men de siste årene har vaksinemotstanden vært med på å drive tallene ned i bl.a. Frankrike, Tyskland, Italia og USA. Resultatet er nye, til dels kraftige, utbrudd av meslinger. Godt synlig i infografikken til Science, og enda mer hos de familiene som rammes. Behovet for gruppeimmunitet gjør at avvisning av vitenskapens resultater om vaksiner, på mer eller mindre subjektivt grunnlag, brått kan bli svært skadelig.

Neste eksempel er menneskeskapte klimaendringer. Som for vaksiner er forskningen på feltet bygget opp over lang tid. Jordens temperatur holdes på et jevnt og levelig nivå av drivhuseffekten, og blant de viktigste drivhusgassene i atmosfæren er karbondioksid (CO2). De siste 150 årene har mengden $\mathrm{CO}_{2} \mathrm{i}$ atmosfæren økt med $40 \%$, fordi samfunnet vårt får energien sin ved å hente olje, kull og gass opp fra bakken, for så å brenne det (Stocker, 2013). Da flyttes millioner år gamle, såkalt fossile, karbonlagre tilbake i naturens kretsløp, med en forsterket drivhuseffekt som én av mange konsekvenser. Dermed endres klimaet vårt på en såpass dramatisk måte at det vil skape store problemer for natur og samfunn, hvis vi ikke bremser utviklingen i tide.

Innholdet i «klimadebatten» har lenge stått mellom et klart budskap fra forskere ( $\mathrm{CO}_{2}$-utslippene må ned, ellers får det store, globale konsekvenser») og sterke motreaksjoner fra ulike særinteressegrupper («forskerne tar feil / fornybar energi kan ikke ta over / klimasaken er en liberal-sosialistisk konspirasjon / ...»). I enda større grad enn for vaksinedebatten har vi i klimasaken også sett systematiske forsøk på å undergrave de tydeligste talspersonene. Den amerikanske klimaforskeren Michael Mann har for eksempel i en årrekke vært skeptikernes mest yndede skyteskive. Mann publiserte i 1999 den såkalte «hockeykøllen», en graf som illustrerer hvor voldsom den globale oppvarmingen er når vi sammenligner med hva vi har sett i moderne tid. Innholdet i grafen er for lengst bekreftet, utvidet og forbedret av en liten hær av andre forskere, men å diskreditere Mann er likevel et hovedmål blant grupperinger som, av ulike grunner, ønsker å motarbeide klimaforskningens budskap (Oreskes \& Conway, 2010; Mann, 2013). 
Avvisning av klimaforskning, på mer eller mindre subjektive grunnlag, er skadelig ut over den forvirringen det skaper. Klimaendringer er et så stort og globalt problem at det vanskelig kan håndteres innenfor eksisterende politiske rammeverk. Å bevisst styre verden bort fra bruk av fossile brensler, med alt det innebærer av kostnader samt flytting av økonomisk og politisk makt, er et terra incognita for samfunnet vårt.

Videre sier forskerne at jo tidligere vi tar grep, jo mindre blir risikoen for at noe virkelig dramatisk skjer. Her ligger hovedutfordringen: Kostnadene ved en slik omlegging er store, globale, umiddelbare og relativt lette å kvantifisere. Men nytteverdien ligger i å redusere en risiko som er ujevnt fordelt geografisk, som har effekt først om en stund, og som dessuten er vanskelig å kvantifisere.

Vaksiner og klimaendringer er områder der forskere forsøker å veilede politikere og andre om å endre adferd. De lokker med et felles fremtidig gode eller advarer mot fremtidige problemer, men tilbyr få eller ingen umiddelbare nytteeffekter. Samtidig kan budskapet være skadelig for noen interessegrupper, som den internasjonale petroleumsindustrien. $\mathrm{Vi}$ skal om litt se at dette er typisk der forskning avvises i dagens medier.

Men før vi går videre, må vi takle et kritisk spørsmål: Kan forskere, i kraft av å være eksperter, forvente å bli hørt på så fort de hevder seg enige om en konklusjon?

Nei. Opplagt ikke. Den typen spørsmål som vaksinemotstandere og klimaskeptikere retter mot vitenskapen, er i første omgang helt berettiget. Hvordan vet vi at vaksinene ikke er skadelige? Hvordan vet vi at global oppvarming skyldes $\mathrm{CO}_{2}$ og ikke noe helt annet?

Forskere må kunne svare - og i disse to tilfellene har de gjort det. Grundig. Problemet er dermed ikke skepsis mot forskning i seg selv, men at forklaringen fra vitenskapen overses eller avvises. Uansett hvor rett man måtte ha: Det er mye vanskeligere for forskere å nå frem i mediene med gjentakelser av den samme forklaringen enn det er for skeptikere å nå frem med innvendinger. Etter min oppfatning er asymmetrien i hvor medie- og klikkvennlig en påstand er, en av de fundamentale utfordringene som leder til at motstand mot vitenskap i dag ser ut til å spre seg så raskt. Formidling fortsetter å være en nøkkelutfordring for forskningen, selv lenge etter at hovedkonklusjonene er klare. 


\section{Megatrender: SoMe, clickbait og en overflod av forskning}

Den økende avvisningen av vitenskap skjer ikke isolert. Sammenkoblingen av samfunnet, presset i mediene mot spissede nyheter samt forskningens egen fenomenale vekst er parallelle, globale megatrender som alle bidrar til å gjøre utfordringene større. I en av dem møter forskerne dessuten seg selv i døren, og vi må dermed innse at vi er med på å skape vårt eget problem.

I dag ser vi en ekstrem sammenkobling av verden gjennom internasjonale nyhetskanaler, internett og - så klart - sosiale medier. Meningene våre både formes og forsterkes av folk vi kommuniserer med (Feldman, Myers, Hmielowski \& Leiserowitz, 2014), og enhver kan nå lett finne grupperinger av meningsfeller. For ikke lenge siden var lokalsamfunnet kjernen til de fleste oppfatninger. Bygdas kultur for hva som var akseptert, var utslagsgivende for innbyggernes meninger - på godt og vondt. Sosiale medier og de andre mulighetene moderne kommunikasjon har gitt oss, har forandret dette fullstendig. Nesten uansett hva du mener, kan du nå finne frem til nettverk av likesinnede, enten lokalt eller globalt, gjennom fysiske møter eller nettfora. Ethvert synspunkt kan dermed forsterkes, rett og slett fordi det finnes aksept for det.

Tenk deg et samfunn der de fleste rundt deg aksepterer nytten av vaksiner, eller at klimaendringene er menneskeskapte. Du mener det samme, men har ikke selv tenkt så nøye over saken. Så snubler du over en nettside som avviser forskningen, gjerne i sterke ordelag og med blinkende advarsler. Kanskje er du klar over at aktøren bak nettsiden er i en interessekonflikt med forskerne, enten faglig eller økonomisk, men det i seg selv svekker ikke argumentene. Naturligvis blir du sittende igjen med spørsmål. Sannsynligvis har ingen rundt deg gode svar, fordi innvendingene ofte er tekniske og fulle av forvirrende stråmannsargumentasjoner. Kanskje er det vanskelig å ta opp temaet, fordi du ikke vil bli sett på som en «avviker». Men på nett og i sosiale medier, tilgjengelig ved et enkelt og diskré Google-søk, finner du andre som lurer på det samme. I dag er de som avviser vitenskap, langt flinkere enn forskere til å bruke mulighetene moderne medier tilbyr. Veien fra Google til å få forsterket en gryende skepsis er skremmende kort. 
Sosiale medier og sammenkoblingen av verden er utvilsomt et gode, men med den skyggesiden at de lar alle synspunkter finne forsterkning. Deriblant - dessverre - avvisning av vitenskap uten solid faglig begrunnelse.

En annen relevant megatrend er tempoet i toppen av nyhetsbildet. Vi er et forbrukersamfunn, ikke bare av energi og råvarer, men av underholdning, informasjon og lett intellektuell stimulans. Nyhetsoverskrifter er noe av det vi sluker mest av, og blir skuffet hvis nettavisen har samme toppsak i mer enn fem minutter av gangen.

Koblet med en økende grad av reklamefinansiering av mediehusene, ender vi med et press i retning av skarpt vinklede, gjerne kontroversielle overskrifter som får forbrukerne til å klikke, like og dele. Sosiale medier som Facebook og Twitter fôrer opp under denne tendensen. De leverer en evig skiftende informasjonsstrøm tilpasset brukerens spesielle ønsker og interesser, og belønner saker som får mye respons, med bedre synlighet.

Konsekvensen er en positiv tilbakekobling for overskrifter som får oss til å heve øyenbrynene. Det samme, gamle budskapet fra forskere om hundre år gammel kunnskap faller ikke i den kategorien. Da selger skepsis, alternative forklaringer og angrep på etablerte forskere langt, langt bedre.

I likhet med sosiale medier er tilgangen til raske nyheter og et system som gir oss den informasjonen vi er mest interessert i, goder for samfunnet. Skyggesiden her er imidlertid at det blir vanskeligere å nå frem med det etablerte og litt tørre, som vitenskap gjerne er før den blir samfunnsrelevant.

En siste viktig megatrend står vitenskapen selv for. Den er til en viss grad et offer for sin egen suksess (Sarewitz, 2016). Ingen betviler egentlig den vitenskapelige metode. Vi aksepterer at universiteter, institutter, professorer og doktorander stadig utvider hva vi vet om natur, samfunn og teknologi. Følgelig brukes det mye penger på forskning, og antallet forskere vokser enormt. UNESCO anslo i 2015 at det var over tre millioner årsverk globalt innen aktiv forskning, og et tilsvarende antall i støttefunksjoner (UNESCO, 2015). Disse forskerne gir ut over to millioner fagfellevurderte artikler i året, og tallet bare øker.

Produksjonen av kunnskap har blitt så stor at ingen lenger klarer å holde oversikten over den. Det gamle systemet, der forskere først leser seg opp på etablert kunnskap og så tar det neste, lille steget videre, står derfor 
i fare for å kollapse under sin egen vekt. Det gjør ikke situasjonen bedre at unge forskeres eneste håp om å få seg fast jobb innenfor akademia, er gjennom å publisere mest mulig og synligst mulig, og dermed med spissede vinklinger på resultatene. Fersk forskning blir stadig mer tabloidisert, drevet av de samme to trendene vi akkurat har sett på: sosiale medier og presset på toppen av nyhetsbildet. Også forskning kan tolkes og vinkles, og målgruppen for vitenskapelige artikler - andre forskere er like mottakelige for «clickbait» som resten av samfunnet.

Eksplosjonen innenfor vitenskap har direkte konsekvenser for trenden med «alternative fakta», som følge av hvordan den vitenskapelige metode fungerer. Si at noen har utviklet en ny vaksine. Da vil vi gjerne vite om den virker, og om den kan ha skadevirkninger. Dette tester vi ved å følge med på vaksinerte mennesker, helst i et planlagt dobbeltblindforsøk. Men en slik undersøkelse vil alltid innebære en viss grad av tilfeldighet, og vi forventer både positive og negative resultater. Så må vi bruke statistikk, basert på mange uavhengige forsøk, for å bedømme om nytteverdien er sterkere enn eventuelle bivirkninger.

På papiret er fremgangsmåten grei, men i den virkelige verden vil noe helt annet skje. Forskerne bak hvert studium har behov for å få resultatene publisert og frem i nyhetsbildet, for å fremme egne karrierer og vise de finansierende myndigheter at de bruker pengene til noe fornuftig. Etisk er det ikke noe galt i å formidle egen forskning, så lenge en tar med hvordan resultatene passer inn i det store bildet. Så langt er det imidlertid vanskelig å komme med i en nyhetsartikkel. Og om en er så heldig å få publisert resultatene sine i Science, Nature eller et beslektet tidsskrift, er det store bildet gjerne skjult allerede fra starten av, fordi disse tidsskriftene også foretrekker nyhetsverdige gjennombrudd (Schekman, 2013).

Dernest kommer skjevheten mellom «kjedelige» og kontroversielle nyvinninger. Når en femte forskergruppe finner en positiv effekt av samme vaksine, er det vanskelig å få publisert resultatene i en synlig journal samt oppnå nyhetsdekning. Men hvis den neste gruppen er den som - enten reelt eller per forventet tilfeldighet - finner lav effekt og store bivirkninger, blir nyhetsverdien desto større. Motstridende resultater favoriseres, og vinkles ofte slik at det velter all tidligere kunnskap. Dette til tross for at vi, statistisk sett, nesten er garantert å få slike konklusjoner. 
Den vitenskapelige metoden krever at både positive og negative resultater sees i lys av summen av forskning på samme tema. Dette er krevende, og ligger som regel utenfor hva selv drevne vitenskapsjournalister klarer å formidle til det brede publikum.

Så kommer konsekvensene av en gryende skepsis. Hvis noen først har blitt kritisk til vitenskapen, og søker etter informasjon i sosiale medier eller i det raske mediebildet, vil de så å si alltid finne forskning som støtter opp under deres syn. Motstridende resultater, derimot, har man en tendens til å avvise.

Er du kritisk til vitenskapen, eller ønsker å svekke konklusjoner derfra, vil dagens forvokste vitenskap selv gi deg mer skyts. Sosiale medier og et hektisk, reklamedrevet mediebilde forsterker denne tendensen. «Alle forskere er enige om at global oppvarming er menneskeskapt», sier klimaforskere. «Professor X i Tyskland sier noe helt annet», svarer motstanderne. Slik vil det fortsette å være, fordi forskningen har blitt så altomfattende og stor. Bredden i resultater er et gode, fordi det betyr at vi har undersøkt dypere og bredere, men god bruk av resultatene krever modenhet fra samfunnet som bestilte dem.

At noen titulerer seg «forsker», er dermed ikke lenger nok til at vi blindt kan stole på dem (i den grad det noen gang har vært det). Forbrukere av informasjon må lære seg å være skeptiske både til budskap og til hvem som fremsetter dem. Tidvis må de også selv gjøre en innsats for å sette seg inn i hva andre forskere sier. Da kan det være nyttig å identifisere hvilke nyhetssaker om forskning som er mest utsatt for motstand fra særinteresser. Det skal vi ta en titt på nå, før vi går videre til å se på hva forskere selv kan gjøre for å bøte på situasjonen.

\section{Hvor slaget mellom vitenskap og særinteresser står}

Det aller meste av moderne kunnskap blir ikke jevnlig trukket i tvil. Vitenskapen har lagt en god del av grunnlaget for det moderne samfunn gjennom medisin, teknologi og mye annet. Det er også mange referanser til vitenskap og forskning i det offentlige rom, hvis vi bare ser etter. De fleste nyhetssaker som går dypere enn å referere noe som akkurat har 
hendt, inneholder referanser til hvordan verden «er». Henvisninger til felles kunnskap vi alle har, ofte kjent siden barneskolen.

Men noen typer kunnskap virker ekstra utsatt for kritikk, alternative fakta og systematiske angrep. Områder hvor det for allmenheten kan se ut som om forskningsfronten ikke er i bevegelse, selv når forskere flest ble enige for lenge siden. Hvis vi kan vi finne fellestrekk for arenaene der særinteresser oftest kommer med innvendinger, blir det enklere for oss å være forberedt.

Jeg ser for meg at skjæringspunktet mellom vitenskap og samfunn kan deles opp på to måter: Først et skille mellom hvorvidt ny kunnskap påvirker hver og en av oss, det vi kan kalle lokal nytte, eller om den handler om felles, globale goder. Så et skille mellom hvorvidt en nyvinning har umiddelbar nytte, eller om effekten er mer langsiktig. Dermed får vi fire kategorier: Global, umiddelbar nytte; global, men langsiktig nytte; og tilsvarende for lokal nytte. En slik inndeling kan hjelpe oss med å forstå hvor motstanden mot vitenskap er sterkest, og dermed gjøre oss mer oppmerksomme når det trengs.

Kunnskap med umiddelbar, lokal nytte kan vi kalle «wow»-kategorien. Her finner vi ting vi selv kan bruke, og hvor vi kan se fremskrittene. Antibiotika er et godt eksempel. Du blir syk, får en pille, og så sant diagnosen var riktig, blir du frisk igjen. Wow! Få eller ingen betviler slik kunnskap, for selv om den er ny, drar vi raskt nytte av resultatene. Og om noen skulle ønske å stille spørsmål, vil de fleste anekdoter og personlige vitnemål virke mot skepsisen.

Forskningsresultater med umiddelbar, men global virkning kan vi kalle «kjekt å vite». Her er nyheter som ikke påvirker oss direkte, men som vi likevel umiddelbart forstår vil være en god ting. Et eksempel fra teknologien er utviklingen av halvledere. De færreste vil selv bruke kvantefysikk til å beregne et båndgap, eller forstå hva det innebærer. At halvledere er selve grunnlaget for den teknologiske revolusjonen, er likevel allment akseptert. Et annet eksempel vil være en nyvinning som billig lar oss fjerne plast fra verdenshavene. Det påvirker oss ikke direkte, men nytten for verden er opplagt. Heller ikke her vil du finne så mange skeptikere, siden nytteverdien er rask og opplagt. 
Kunnskap med lokal, men langsiktig effekt, som gagner hver og én av oss, men tar tid å se effektene av, kan vi kalle «for mitt eget beste». En sunn livsstil er et godt eksempel. Legevitenskapen forteller oss at vi bør ha det, og - innenfor en viss usikkerhet - hvordan vi skal gå frem. Vi merker ikke fra dag til dag om vi opprettholder den sunne livsstilen, men vi har nok eksempler fra familie og nærmiljø til at det er lett å se konsekvensene av å overse forskningen. Forsiktig omgang med kilder til radioaktiv stråling er et annet eksempel, relevant for villigheten til å betale for tiltak mot radongass i kjelleren. Det finnes få alternative nyheter og aktive kampanjer mot radonbeskyttelse.

Det er først i den siste kategorien, kunnskap der vitenskapen bare kan love langsiktig og global nytte, at vi virkelig møter skepsis. «Altruisme» er et dekkende navn på slike temaer. Vaksiner illustrerer problemet godt. Vi ser aldri noen lokal nytte av å la barna våre vaksineres, siden den reelle effekten er fravær av en sykdom. Vi er avhengige av at forskere kommer tilbake til oss, gjerne mange år etterpå, og forteller at antall sykdomstilfeller har gått dramatisk ned. Det samme gjelder for global oppvarming. Forskere advarer om store problemer for samfunnet hvis vi ikke legger om vanene våre, men konsekvensene forblir abstrakte og fjerne i tid. Vi anbefales å gjøre dyre, inngripende valg i dag, valg som i beste fall fører til at vi ikke merker noen som helst konsekvenser på vær og vind. Vi er avhengige av at forskere kommer tilbake til oss, gjerne mange tiår etterpå, og forteller oss at klimaet virkelig ble reddet.

Kunnskap vi kan si «wow» til, aksepterer vi. Gjelder den noe som er «kjekt å vite» eller «for mitt eget beste», går det også greit. Men «altruisme»? Å akseptere en konklusjon levert til oss fra eksperter, et forskningsresultat som griper inn i livet vårt uten å gi umiddelbar nytte, faller oss tungt for brystet. Her har vi identifisert selve sentrum av slagmarken. Men hvorfor er det nettopp er denne kunnskapen vi opponerer mot?

\section{Hvorfor vi avviser forskning}

At eksperter vet best, ligger innebakt i selve begrepet. Likevel ser vi stadig større motstand mot forskning og vitenskap, både organisert og hos folk flest. Vi skal se på tre mulige grunner til dette, én opplagt og to litt 
dypere, som gror ut av megatrendene vi har identifisert. De kan også forstås ut fra inndelingen i lokal eller global, kortsiktig eller langsiktig nytte.

Den opplagte, og minst hyggelige, grunnen er at det er i den enkeltes egeninteresse å skape motstand. Forskningen har selv gjort dette enkelt. Skadevirkninger av røyking er et kjent eksempel. Når vitenskapen kommer til konklusjoner som vil ødelegge salgstallene for en hel industri, er det god business å svekke troverdigheten til resultatene. Enten ved å spre budskap som overser det forskerne sier, ved å gå til systematiske angrep på forskerne selv, eller ved å aktivt skaffe til veie alternative konklusjoner fra egen forskning. Det er godt dokumentert at tobakksindustrien i en periode tok i bruk alle disse virkemidlene (Oreskes \& Conway, 2010). Tilbake satt et publikum som var i fullstendig villrede om hvorvidt røyking forårsaket kreft eller ikke - en stund. Etter hvert ble sammenhengen såpass tydelig for alle som kjente mange røykere, at forskningen ikke lenger kunne motsis på en troverdig måte.

De tre megatrendene - sosiale medier, nyhetspress og veksten innen forskning - gir fruktbar mark for agenter for slike særinteresser, som ønsker å misbruke den tilliten fageksperter over tid har bygget. Slik misbruk forekommer, både på stor og liten skala, og hver gang undergraver den folks tiltro til forskning enda litt mer. Kort fortalt: Folk avviser forskning fordi de har blitt utsatt for en rekke "debatter" mellom tilsynelatende likeverdige eksperter, stort sett ført over hodene på dem.

En dypere grunn til motstanden finner vi i forholdet vårt til dogmatiske autoriteter generelt. Det er ikke lenge siden lokalsamfunnets største autoritet var presten, og ordene i den tykke boken han prekte ut fra. I dag er å «tenke sjæl» regnet som en av våre viktigste dyder. Vi gjør vårt beste for å gi barna våre all den kunnskapen de trenger for å ta informerte valg i voksenlivet. Religionene dør ikke ut av den grunn, men å være religiøs er i dag - i vår del av verden - blir i stadig større grad regnet som et personlig valg.

Men la oss nå se på klimasaken igjen. Den tydeligste avsenderen bak det samlede budskapet fra verdens klimaforskere er FNs klimapanel (IPCC). Denne grupperingen av hundrevis av forskere, valgt ut på en måte som er ugjennomsiktig for folk flest, samler og vurderer de siste forskningsresultatene om klimaendringene. Deretter presenteres status i 
bøker som er tykkere og mer ugjennomtrengelige enn noen latinsk bibel, og formidles til folket av talsmenn som til forveksling høres ut som tidligere tiders prester. Og siden IPCC er et ekspertorgan, med støtte fra valgte politiske ledere, forventes vi alle å godta det når de råder oss til å legge om livsstilen vår. Forskere kunne knapt fremstått mer autoritært og dogmatisk om de aktivt hadde forsøkt på det (Lucas, Leith, \& Davidson, 2015). Når vi først har kvittet oss med ett sett med dogmer, er det kanskje ikke så rart at vi opponerer mot et nytt sett med uforståelige regler? Du skal kjenne den vitenskapelige metode ganske godt før du fullt ut forstår forskjellen mellom begrepene «forskning viser» og «Gud har sagt».

Til forsterkning av dogmeproblemet kommer den enorme - og stadig økende - mengden av kunnskap vi har samlet. I renessansen kunne enkeltpersoner gjøre fremskritt innen flere fagområder på en gang. I dag er du blant verdens toppforskere hvis du kan si at du har full oversikt over en liten del av en enkelt disiplin. For alle som ikke selv er forskere, må det meste av ny kunnskap bare godtas. Grunnleggende trening i kritisk tenkning hjelper, men også den er avhengig av en viss oversikt over det en skal være kritisk til.

Det er med andre ord veldig mye av grunnlaget for samfunnet, og for vår egen tilværelse, som vi alle bare godtar. Og når vi ikke forstår sammenhengen, ligger det $\mathrm{i}$ vår natur å være skeptisk og forsiktig. En gang $\mathrm{i}$ tiden, før vi bygget trygge byer, var det klokt å bli redd hvis du hørte en ukjent lyd i buskene. Den kunne ha sammenheng med noe farlig. I dag sitter denne forsiktigheten igjen, i form av en tendens til å la oss skremme dersom noen antyder en sammenheng som kan være skadelig.

Et eksempel fikk vi i 1986, da Tsjernobyl-ulykken resulterte i stor spredning av radioaktivitet over deler av Nord-Europa. Radioaktivitet er noe å være forsiktig med, også ifølge vitenskapen, men den frykten som bredte seg i årene etterpå, og som fortsatt henger i, sto ikke i forhold til de reelle konsekvensene av ulykken. Langt, langt flere mennesker dør eller skades i kullgruver, uten at det har samme utslag for holdningene til kullkraft. En av grunnene til denne oppfatningen er at stråling er noe de færreste forstår, og dermed - med rette - vil være forsiktige med, mens det å grave opp kull, for så å brenne det, ligger nærmere våre egne erfaringer. 
Vaksinemotstand er et annet eksempel. Vi vet ikke hva slags stoffer som sprøytes inn i barna våre, og hvilken virkning de har. Dermed blir vi lett engstelige når noen antyder at det kan være en sammenheng mellom vaksiner og sykdom. At motargumentet kommer fra et autoritært og dogmatisk korps av forskere med lang utdanning, hjelper ikke, selv om det rasjonelt sett burde vært omvendt.

Vi avviser vitenskap fordi forskere og eksperter gjerne fremstår dogmatisk, og fordi vi er redde for konsekvensene dersom de likevel skulle ha tatt feil.

En tredje grunn til å bli kritisk til forskning finner vi i skillet mellom umiddelbar og langsiktig nytte. For hva er egentlig nytte? Når kan vi si at rådene fra forskningen gjør samfunnet, eller vår egen tilværelse, bedre? For «wow»-forskning som ny og bedre antibiotika er svaret opplagt. Nytten er umiddelbar. Men kategorien «altruisme», der vi har sett at mesteparten av skepsisen dukker opp, kjennetegnes av at den ikke har noen slik umiddelbar nytte. Utfordringen med å formidle slik kunnskap ligger ikke bare i å få frem at hvis vi gjør en endring i dag, vil det forandre på noe i fremtiden, men også i å begrunne at denne forandringen vil være til det bedre.

Igjen er klimaendringene et godt eksempel. En vanlig innvending er denne: «Jo da, bruk av fossile brensler endrer kanskje klimaet, men litt ekstra temperatur er bare bra for oss - og dessuten er $\mathrm{CO}_{2}$ plantemat.» Skepsisen rettes i dette tilfellet ikke mot forståelsen av klimasystemet, men mot antakelsen om at vi får problemer hvis klimaet endrer seg. Dette er en fundamentalt forskjellig debatt, med annen forskning i bunnen og andre eksperter på banen. En ytterligere innvending er den at arbeidet med å redusere $\mathrm{CO}_{2}$-utslipp vil kreve internasjonal regulering og statlig - eller overstatlig - styring av folks liv. For folk på den konservative siden av politikken, til dels også den liberale, er dette fy-ord, men hvis ekspertenes konklusjoner er riktige, er styringen rasjonell. Dermed trekkes, instinktivt eller bevisst, selve grunnlaget i tvil, siden det går på tvers av en politisk overbevisning. Men spørsmålet om regulering er egentlig en tredje, uavhengig debatt, som handler om hvorvidt vi ønsker å iverksette tiltak for å løse problemet, eller bare vil takle det når det kommer. 
Nå ser vi konturene av det fulle spekteret av utfordringer med å kommunisere «altruistisk» kunnskap på en troverdig måte. Først må ekspertene nå frem med budskapet om at grunnlaget er solid. Så må de få aksept for at den nytten de ser, faktisk er en nytte - i kamp mot skepsis på grunn av manglende kunnskap, på grunn av politiske ideologier som ikke er enige i virkemidlene, og på grunn av økonomiske interesser som kan bli skadelidende på kort sikt. I tillegg kommer at det faktum at den «altruistiske» kunnskapen per definisjon ikke har noen umiddelbar effekt, og at det ofte er snakk om å unngå fremtidig skade - en usynlig «nytte» - snarere enn å oppnå et konkret gode. Så legger vi til megatrendene som gjør formidling av kontroversiell vitenskap stadig vanskeligere. I møte med et slikt sett med utfordringer er det nesten utrolig at vitenskapen fortsatt når gjennom så godt som den gjør.

Men: Heldigvis er det slik at første steg for å unngå et problem er å være klar over at det eksisterer. Nå som vi har identifisert utfordringene, kan vi til slutt se på hva vi kan gjøre med dem.

\section{Formidling i møte med særinteresser}

Forskere kan ikke selv løse alle utfordringene med «alternative fakta» og angrep fra særinteresser, men vi kan bidra. Vi må gå i oss selv for å unngå å gjøre problemet større, og vi må innta en mer sentral plass på slagmarken - i grenseflaten mellom vitenskap og samfunn. Kommunikasjon er stikkordet, å akseptere en ny rolle for fagformidlere.

Avvisning av forskning er ikke et problem fordi ekspertrollen hever forskere over kravet om å begrunne konklusjonene sine, eller fordi en ekspert ikke skal måtte tåle kritikk. Problemet oppstår fordi vi risikerer å ta unødvendig gale valg, både som enkeltpersoner og som samfunn, dersom vi ikke tar vitenskapens konklusjoner inn over oss.

A fortsette bruken av fossile brensler i stor skala vil, ifølge moderne klimaforskning, være et samfunnsmessig galt valg. Konsekvensene av å la være å vaksinere barna våre ser vi i dag, i form av en økning i forekomsten av meslinger i den vestlige verden. I begge tilfeller må ekspertene være forberedt på å begrunne rådene sine, og alltid være ærlige om hvor grensene 
for dagens kunnskap ligger. Men de må ikke få autoriteten sin trukket i tvil av særinteresser. Da undergraves tilliten til nettopp den metodikken vi har brukt for å få samfunnet frem dit det er i dag, og som vi sårt trenger for å møte kommende utfordringer: fortsatt befolkningsøkning, fattigdom, antibiotikaresistens, konkurranse om begrensede naturressurser, og - ikke minst - klimaendringer. Alle disse er globale anliggender som krever at vi er i stand til å bruke all eksisterende kunnskap til å vurdere kortsiktige behov og ønsker opp mot langsiktig nytte.

Først og fremst er vi selv nødt til å erkjenne hvordan vi er med på å gjøre problemet større. En vanlig klage forskere imellom er hvordan mediene forenkler og sensasjonsvinkler forskningsnytt, selv om «alle» er klar over at kunnskapsbildet egentlig er mer nyansert. Det vi sjelden innrømmer, er at vi selv både drømmer om og er avhengige av å gjøre det samme. Alle forskere ønsker å være fremragende, å vinne store bevilgninger og å bli antatt i topp-tidsskrifter. Men hver gang vi vinkler et resultat inn mot mulig publikasjon i Nature eller Science, eller gjør et stort nummer ut av mulig samfunnsnytte i en søknad til Forskningsrådet eller EU, er vi med på å øke forventningspresset.

Det er ikke nødvendigvis galt å spisse en konklusjon for å nå bredest mulig ut med den, men jo mer vi gjør det, jo større vil problemet med avvisning av forskning bli. Folk blir raskt trette av «sensasjoner», som bare uker senere kan bli avløst av motstridende forskning. Og selv to studier som i utgangspunktet er konsistente, men som vinkles ulikt, kan brukes av særinteresser med egne agendaer til å skape inntrykk av at forskerne er uenige med seg selv. Til en viss grad må vi altså feie for egen dør, før vi snur blikket for skarpt mot ytre faktorer.

Det neste vi kan gjøre, er å bli klar over utfordringene ved å nå frem med «altruistisk» kunnskap. Ved å ta hensyn til dem i kommunikasjonen vår, kan vi til en viss grad unngå problemene før de oppstår.

Vi har sett at folk ikke responderer godt på dogmatiske budskap fra fjerne autoriteter. Dette er egentlig en konsekvens av noe formidlingsteoretikere lenge har forsøkt å få frem, nemlig at målgruppen for formidling ikke må anses som «tomme tønner» (Sturgis \& Allum, 2004). En rådende tanke blant akademikere har lenge vært at bare vi kan få kunnskapen ut til folket, fylle hullene i det de vet fra før, så vil de begynne å handle 
rasjonelt ut fra en ny og større kunnskapsbase. Et behagelig prinsipp, men dessverre ikke riktig. Folk har alltid kunnskap fra før, og bruker den til å gjøre vurderinger og ta valg. Når forskere kommer med ny informasjon, må den konkurrere med det folk mente de visste. Ingen liker å bli fortalt av en ekspert at alt du tror du vet, er feil. Tilhøreren havner på defensiven, og blir lite mottakelig for budskapet.

For «altruistisk» kunnskap er «tomme tønner»-tenkningen ekstra problematisk. Ikke bare må mottakerne overbevises om å erstatte gammel kunnskap med ny. I mange tilfeller må et eksisterende handlingsmønster, som er nyttig og behagelig for den enkelte i dag, endres for å oppnå en fremtidig - og felles - nytte.

Men hva gjør vi, helt konkret?

Dagens formidling og kommunikasjon av forskning må både fortsette og styrkes. Vi kan også forsøke å komme skepsisen i forkjøpet (van der Linden, Leiserowitz, Rosenthal \& Maibach, 2017). Men ut over det må vi åpne for en ny generasjon formidlere som velger seg roller nærmere den offentlige debatten enn det som har vært vanlig til nå. (Se f.eks. Kierulf, 2017.)

Et godt motto for denne gruppen kan være «styrke og veiledning». «Styrke», fordi vi alltid vil måtte fortsette å kommunisere de grunnleggende sannhetene. Vaksiner virker, men hvorfor gjør de det? Klimaet endres, men hvorfor skyldes det vår bruk av fossile brensler? Som formidler er det lett å bli oppgitt over at man aldri synes å nå helt frem med slike budskap, men i dagens mediehverdag er vi nødt til å holde trykket oppe. Vi må forbli sterke, og vi må finne nye, kreative, overraskende - men likevel korrekte - måter å si ting på. Da møter vi forskningens motstandere på slagmarken allerede lenge før offentligheten blir klar over at de er der. Det blir de som må sloss mot folks eksisterende holdninger. Og deres kamp vil bli i motbakke. Forskning kan begrunne og forklare hvorfor det vi hevder, er sant. Vi kan også legge frem forbehold og usikkerheter på en slik måte at det illustrerer fronten innen feltet. Hvor er debattene i dag, og hvilke diskusjoner har vi avgjort og gått videre fra?

«Veiledning» er der det virkelig nye ligger. I en stresset mediehverdag, der autoriteter kaster forskningsresultater på hverandre som skitne 
snøballer, er det få som orker å sette seg ned og virkelig gå gjennom påstandene. Mange ønsker nok å tro på ekspertene, og å ta de nødvendige konsekvensene av det de sier, men hvordan velger man hvilken ekspert som er den riktige? Forskningsbasert kunnskap er den eneste som kan komme med velbegrunnet veiledning - fra hvordan verden er, og frem til hva vi kan gjøre med det.

Mange har diskutert hvordan, og hvorvidt, forskning kan ta oss fra «er» til «bør», altså fra kunnskap til normative handlingsregler. Forskere står fritt til å gå hele veien i sin kommunikasjon, men de løper en risiko for å bli gruppert sammen med politikere og aktivister - og dermed miste noe av sin slagkraft.

Det som virkelig trengs, er en mellomting. Formidling som tar utgangspunkt i «er», og så skisserer hvilke muligheter vi har. Ofte tar kunnskapen oss lenger enn mange er klar over, uten at den trenger å bli normativ.

Et eksempel, igjen fra klimasaken, er konsekvensene av Parisavtalen fra 2015, der togradersmålet ble gjort til internasjonal lov. Siden vi vet hvordan klimaet virker, kan Parisavtalen oversettes til et budsjett for hvor store utslipp av klimagasser vi kan tillate oss i årene som kommer. Og siden vi også har en viss oversikt over hvor store økonomiske og teknologiske omveltninger samfunnet er i stand til å gjennomføre, legger avtalen opp et klart løp for de neste hundre årene (Anderson \& Peters, 2016).

A fortelle hva som kreves for å holde Parisavtalen, er ikke normativt, men veiledende. Normativt blir det først hvis vi legger føringer for hvilke løsninger samfunnet bør velge. Under overskriften «styrke og veiledning» bør klimaformidlere gå så langt de klarer i å skissere hvilke kutt vi må gjøre i utslipp, hvilke muligheter vi har for å gjennomføre dem, og hva konsekvensene blir hvis vi velger ikke å benytte disse mulighetene. Valg av mulighet bør deretter bli opp til valgte politiske ledere, og velgermassene bak dem.

Utfordringen for en slik formidlerrolle er at den vil oppleves som normativ lenge før den faktisk er det - delvis nettopp på grunn av alternative fakta. En kan også spekulere i at alternative fakta aktivt kan brukes for å hindre forskere i å påta seg en slik rolle. Kunnskapsbaserte resonnement 
er kraftfulle, og de er vanskelige å slå tilbake mot. Men så lenge vi tror på vitenskapens metode, og på at fri forskning skal kunne gi noe tilbake til samfunnet, er det nettopp her vi må sette inn støtet. Forskere må våge å være relevante, men samtidig forstå at de ikke alene kan sette normer. Samfunnet må tåle å få høre hva vitenskapen kommer frem til, og hvilke konsekvenser handlingene våre har, selv når det går mot det vi ønsker skal være sant.

\section{Konklusjon}

Samfunnet vårt har aldri vært mer komplekst enn i dag. Vi høster stadig flere goder fra forskning og vitenskap, men møter også større globale utfordringer. I en slik situasjon er fremveksten av alternative fakta svært uheldig, til og med direkte skadelig, men den er også helt forståelig.

I møte med gryende skepsis, og med misbruk av vitenskapens autoritet fra særinteresser, er det spesielt innen kommunikasjon og formidling at forskningen selv kan slå tilbake. De gamle sannheter må formidles, på ny og på ny, sammen med begrunnelsen for hvordan vi vet det vi vet. Slik bygger vi grunnlaget for fortsatt tro på den vitenskapelige metode. Videre må vi våge å veilede. Ikke formane eller fremstå som normative, men skissere de mulige valgene samfunnet har, ut fra det beste av kunnskapen vår. Her har også formidling av usikkerhet en sentral rolle, for å vise forskjellen på hundre år gamle grunnsteiner og ny kunnskap fra forskningsfronten.

Vi kan styrke og veilede. Ikke alle forskere ønsker å stå i offentligheten med en slik rolle, og det er greit. Men vi må alle akseptere at noen gjør det, og at de går lenger langs aksen fra «er» til «bør» enn vi selv ville ha gjort. Kun på den måten kan akademia beholde sin plass som forvaltere og utviklere av samfunnets kunnskapsgrunnlag. Og kun på den måten kan vi vise at forskning er like relevant i dag som noen gang før, og beholde den tilliten vi trenger fra samfunnet for å kunne legge kunnskapsgrunnlaget for fremtiden. 


\section{Referanser}

Anderson, K., \& Peters, G. (2016). The trouble with negative emissions. Science, 354(6309), 182-183. https//doi.org/10.1126/science.aah4567

BBC. (2017). Measles outbreak across Europe. Hentet fra http://www.bbc.com/news/ health-39419976

Corner, A., \& Groves, C. (2014). Breaking the climate change communication deadlock. Nature Climate Change, 4, 743-745. https//doi.org/10.1038/nclimate2348

Feldman, L., Myers, T.A., Hmielowski, J.D., \& Leiserowitz, A. (2014). The mutual reinforcement of media selectivity and effects: Testing the reinforcing spirals framework in the context of global warming. Journal of Communication, 64, 590-611. https//doi.org/10.1111/jcom.12108

Kierulf, A. (2017). «... en åpen og opplyst offentlig samtale» - Forskningsformidling som demokratisk ansvar. Nytt Norsk Tidsskrift, 33, 36-50. https//doi.org/10.18261/ issn.1504-3053-2017-01-04

Lucas, C., Leith, P., \& Davidson, A. (2015). How climate change research undermines trust in everyday life: A review. WIREs Climate Change, 6, 79-91. https//doi. org/10.1002/wcc.320

Mann, M. (2013). The hockey stick and the climate wars. Columbia University Press.

Oreskes, N. (2011). Merchants of doubt. Bloomsbury Press.

Oreskes, N., \& Conway, E.M. (2010). Merchants of doubt. Bloomsbury Press.

Sarewitz, D. (2016). Saving science. The New Atlantis, 49, 4-40.

Schekman, R. (2013, 12 9). How journals like Nature, Cell and Science are damaging science. The Guardian. Hentet fra https:/www.theguardian.com/ commentisfree/2013/dec/og/how-journals-nature-science-cell-damage-science

Science. (2017, 04 27). Here's visual proof why vaccines do more good than harm. https//doi.org/10.1126/science.aal1107

Stocker, T.D.-K. (2013). Climate change 2013: The Physical Science Basis. Contribution of Working Group I to the Fifth Assessment Report of the Intergovernmental Panel on Climate Change. I IPCC. Cambridge University Press.

Sturgis, P., \& Allum, N. (2004). Science in society: Re-evaluating the deficit model of public attitudes. Public Understanding of Science, 13(1), 55-74.

UNESCO. (2015). Hentet fra http://data.uis.unesco.org/Index.aspx?DataSetCode= SCN_DS\&lang=en\&popupcustomise $=$ true

van der Linden, S., Leiserowitz, A., Rosenthal, S., \& Maibach, E. (2017). Inoculating the public against misinformation about climate change. Global Challenges, 1. https//doi.org/10.1002/gch2.201600oo8 



\section{Om bidragsyterne}

Gisle Andersen, seniorforsker ved NORCE Samfunn Rokkansenteret, har doktorgrad i sosiologi fra Universitetet i Bergen. Han har særlig forsket på hvordan natur- og miljøpolitikken i Norge har utviklet seg siden 2.verdenskrig og betydningen av vitenskapsbasert ekspertise i miljøpolitiske beslutningsprosesser. Dette er publisert i fagboken Parlamentets natur.

Ingrid Bay-Larsen har vært medlem i Den nasjonale forskningsetiske komité for (naturvitenskap og teknologi) NENT siden 2014 og arbeider til daglig som forskningsleder ved Nordlandsforskning, gruppe for Miljø og samfunn. Bay-Larsen har doktorgrad fra Norges fiskerihøyskole, UiT Norges arktiske universitet. Hennes forskningsinteresser omhandler vitenskapens rolle i kunnskapsbasert politikk og forvaltning, med særlig vekt på det grønne skiftet og bærekraftig utvikling av naturbaserte næringer i nord.

Maiken Bjørkan er seniorforsker ved Nordlandsforskning og er postdoktor gjennom HAVBRUK2. Bjørkan har sin spesialisering innenfor fiskeri og havbruk. Hun er involvert i forskning om ulike aspekter av kystsoneforvaltning, med særlig fokus på rollen til kunnskapsbasert forvaltning og medvirkning. Hun er opptatt av utfordringer knyttet til usikkerhet og kontroverser i samfunnsspørsmål, som fiskekvoter, arealbruk og bærekraftig utvikling.

Tone G. Bjørndal er prosjektleder i Norsk klimastiftelse. Hun har en MSc i Klimaforandringer fra Københavns Universitet, og en MA i Teknologi, Innovasjon og Kunnskap fra TIK Senter for teknologi, innovasjon og kultur ved Universitetet i Oslo. Her studerte hun henholdsvis bruken av begrepet klimanøytralitet i norske regjeringsdokumenter, samt kontroversen rundt petroleumsutvinning nær den Arktiske iskanten. 
Anders Braarud Hanssen er FoU rådgiver ved Fakultet for Teknologi, Kunst og Design (TKD), OsloMet, og ph.d.-stipendiat ved Universitetet i Twente/OsloMet. Tidligere publikasjoner inkluderer: Anders Braarud Hanssen, Ellen-Marie Forsberg, Hanne Marie Nielsen, Anne Helena Kettunen og Ingrid Olesen, «The unacknowledged uncertainty of biopatenting: a case study of the AquaBounty patent in the European patent system» (2018) og Ellen-Marie Forsberg, Anders Braarud Hanssen, Hanne Marie Nielsen og Ingrid Olesen, «Patent Ethics: The misaligned view from inside and outside the patent system»(2017), i Science and Engineering Ethics.

Geir Gaarder er naturforvaltningskandidat fra NLH og rådgiver i Miljøfaglig Utredning AS. Han har arbeidet med utredninger av naturmangfold siden 1992. Gaarder har deltatt i utvikling av metoder for inndeling, registrering, verdisetting og konsekvensutredning av naturtyper for ulike offentlige etater.

Stig S. Gezelius er professor i sosiologi ved Høgskolen i Sørøst-Norge. Han arbeidet som forsker ved Norsk institutt for landbruksøkonomisk forskning (NILF) fra 2001-2014. Som leder for Forskerforbundets lokallag ved NILF fra 2008-2013 arbeidet han spesielt med spørsmål om akademisk frihet i instituttsektoren, inkludert foredragsvirksomhet og retningslinjer for forskeres frihet.

Erlend A.T. Hermansen har doktorgrad i vitenskapsstudier (Science and Technology Studies) fra TIK Senter for teknologi, innovasjon og kultur ved Universitetet i Oslo. Han er seniorforsker på CICERO Senter for klimaforskning og forsker spesielt på hvordan vitenskapelig kunnskap produseres og brukes i politikkutforming og beslutningstaking på ulike nivåer.

Kjellrun Hiis Hauge er leder for forskningsprogrammet Berekraft, medverknad og mangfald, Fakultet for Fakultet for lærarutdanning, kultur og idrett, Høgskulen på Vestlandet. I sin forskning har Hauge vært spesielt opptatt av usikkerhet i kunnskap og usikkerhetens roller i forvaltning og samfunnsdebatter med sterke interessemotsetninger. Hun har anvendt slike perspektiver i forskning på risikovurderinger knyttet til fiskekvoter 
og til petroleumsvirksomhet, samt hvordan man kan få slike perspektiver inn i elevers læring og kritisk demokratiske danning.

Helene Ingierd er sekretariatsleder for Den nasjonale forskningsetiske komité for naturvitenskap og teknologi (NENT). Ingierd har en ph.d. i statsvitenskap fra Universitetet i Oslo. Hun har vært redaktør på en rekke bøker om forskningsetikk, inkludert Internet Research Ethics (med Hallvard Fossheim) og De berørte etter 22. juli (med Vidar Enebakk og Nils Olav Refsdal).

Olve Krange er sosiolog og seniorforsker, Norsk institutt for naturforskning. Hans forskning dreier seg for tiden hovedsakelig om holdninger til store rovdyr og rovdyrkonflikter.

Klaus Mittenzwei er forsker ved Norsk institutt for bioøkonomi (NIBIO) på Ås. Han har vært leder av den lokale gruppen for Samfunnsøkonomene i tidligere NILF og nåværende NIBIO siden 2010. Sammen med John Bryden, vant han i 2013 prisen for beste artikkel i nivå-2 tidsskriftet Sociologica Ruralis for «Academic Freedom, Democracy and the Policy Process» utgitt av European Society for Rural Sociology.

Bjørn K. Myskja er professor i etikk og politisk filosofi, Institutt for filosofi og religionsvitenskap, Norges teknisk-naturvitenskapelige universitet - NTNU. Myskja har særlig forsket innen bioteknologiens etikk og medisinsk etikk, og har blant annet vært medlem av REK Midt-Norge og Bioteknologirådet, og har sittet i flere programstyrer i Norges forskningsråd. Hans nyeste publikasjoner er Knut Jørgen Egelie, Berit Johansen, Sabina P. Strand og Bjørn Kåre Myskja, «The ethics of access to patented biotech research tools from universities and other research institutions» i Nature Biotechnology, 36 (6): 495-499 (2018), og Bjørn Kåre Myskja og Morten Magelssen, «Conscientious objection to intentional killing: An argument for toleration» i BMC Medical Ethics, 19: 82 (2018).

Rune Nydal er førsteamanuensis ved Program for anvendt etikk, Institutt for Filosofi og Religionsvitenskap, NTNU. Nydal er medlem av Den nasjonale forskningsetiske komité for naturvitenskap og teknologi 
(NENT). Han underviser forskningsetikk og teknologietikk. Sammen med Berge Solberg har han redigert boken Juks, uredelighet og god forskning og publisert artikkelen «Kan man være bare litt uredelig?».

Audun Ruud, seniorforsker, Norsk institutt for naturforskning, er utdannet siviløkonom og har en doktorgrad i statsvitenskap. Han har publisert mye rundt politisk styring, iverksetting, strategisk adferd og deltakelse spesielt knyttet til bærekraftig utvikling, energi- og miljøpolitikk og praksis.

Bjørn H. Samset er fysiker og klimaforsker, og forskningsleder ved CICERO Senter for klimaforskning. Samset er aktiv fagformidler og klimadebattant, hovedforfatter i FNs klimapanel og spaltist i Morgenbladet. Han ga ut boken Lys på Spartacus i 2018.

Ketil Skogen er sosiolog og seniorforsker ved Norsk institutt for naturforskning. Hans forskning har i stor grad handlet om konflikter rundt naturvern og utnyttelse av naturressurser, ikke minst i forbindelse med vern og forvaltning av store rovdyr. Skogen har studert slike konflikter i lys av klasseforhold og sosiale endringsprosesser i moderne samfunn.

Berge Solberg er professor ved Institutt for samfunnsmedisin og sykepleie ved NTNU med medisinsk etikk og forskningsetikk som hovedområder. Solberg er nestleder for Den nasjonale forskningsetiske komité for medisin og helsefag (NEM), han er sekretær for den kliniske etikkomiteen ved St Olavs Hospital, og medlem av Helsedirektoratets rådgivende gruppe på bioteknologi og etikk ("Bioreferansegruppa"). Fra 2004 til 2013 var han medlem av Bioteknologinemnda.

Norunn Sæther Myklebust, administrerende direktør i Norsk institutt for naturforskning (NINA), har hatt ulike lederposisjoner i NINA siden 2002, og har vært administrerende direktør siden 2007. Hennes mest relevant tidligere arbeidserfaring er ti år fra Direktoratet for naturforvaltning (nå Miljødirektoratet) med ansvarsområder innen vassdragsforvaltning.

Kristin Wangen er rådgiver i Miljøfaglig Utredning AS siden 2015. Hun har master i Naturressursforvaltning fra NTNU. Wangen har erfaring 256 
med naturtypekartlegging etter metodikken i DN-håndbok 13 siden 2012, og etter Natur i Norge (NiN) siden 2015, samt at hun har noe erfaring med konsekvensutredninger.

Øystein Aas har hovedfag (MSc) i naturforvaltning fra NLH (nå NMBU) (1988), og har graden Dr.agric (2001) fra Institutt for Økonomi og Samfunnsfag på samme sted. Han har jobbet tverrfaglig med anvendt forskning og utredning knyttet til naturressursforvaltning i nesten 30 år og er nå forskningsleder ved Norsk institutt for naturforskning og professor II på NMBU. Han har blant annet deltatt på en rekke konsekvensutredninger, og forsket på planprosesser i flere energiutbyggingsprosjekter. Aas har publisert ca. 50 vitenskapelige fagfellevurderte artikler, to engelske fagbøker og et hundretalls norske fagrapporter. 
